\title{
The Grassland Natural Region of Alberta
}

One of a series of reports prepared for the Special Places 2000 Provincial Coordinating Committee

$$
\text { by }
$$

Alberta Environmental Protection

Natural Resources Service

Recreation \& Protected Areas Division

Natural Heritage Protection and Education Branch 


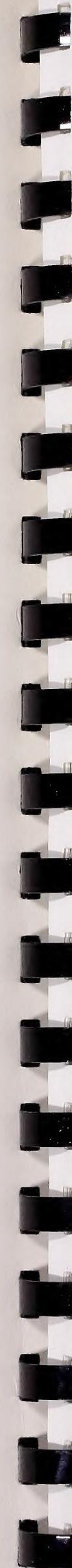




\section{The Grassland Natural Region of Alberta}

One of a series of reports prepared for the Special Places 2000 Provincial Coordinating Committee

by

Alberta Environmental Protection

Natural Resources Service

Recreation \& Protected Areas Division

Natural Heritage Protection and Education Branch

March 1997 


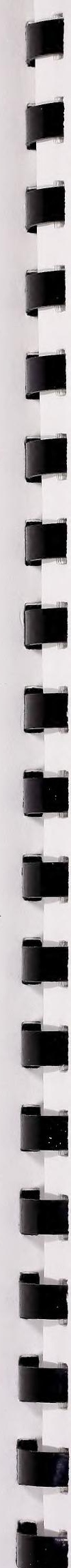




\section{Preface}

This draft report was prepared by staff of Environmental Protection and has not undergone review by professionals in the fields of protected areas, natural history and prairie conservation. It is intended to provide background information on the Grassland Natural Region from a protected areas perspective. The suggestions and recommendations are left general and qualified. More specific suggestions and recommendations can be made on the basis of further detailed analysis of the identified blocks of landscapes suggested in this report for protected areas consideration. This further analysis will provide spatial coverage of each Level 1 Natural History Theme within distinct mapped polygons. If required, this analysis is available from Alberta Environmental Protection for all provincially, nationally and internationally ranked Environmentally Significant Areas. The data housed within and the capacity of the Alberta Natural Heritage Information Centre (ANHIC) in Edmonton were important for generating some of the findings of this report. The report contains professional comment and advice but it is not the policy of the Government of Alberta. 


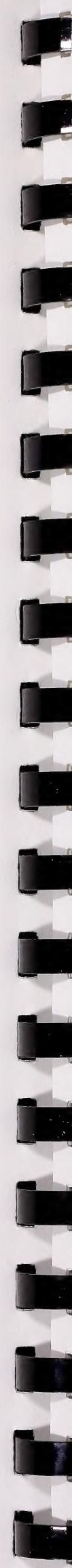




\section{Table of Contents}

\section{Part 1 Introduction and Background}

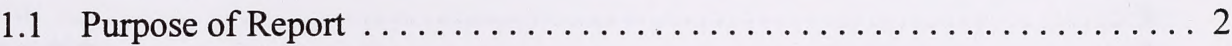

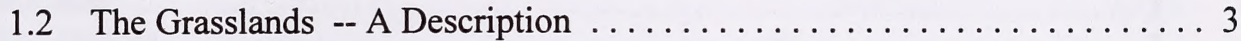

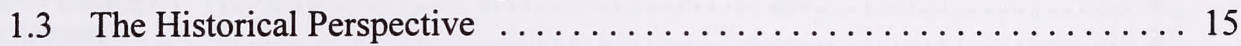

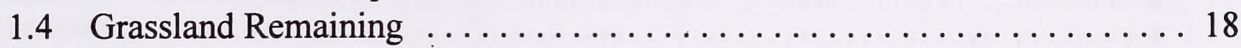

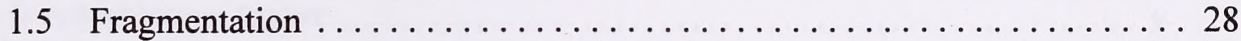

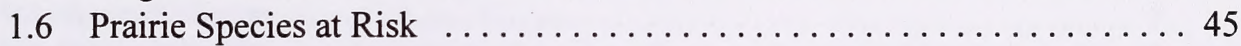

1.7 Notable Prairie Species and Species Groups $\ldots \ldots \ldots \ldots \ldots \ldots \ldots 67$

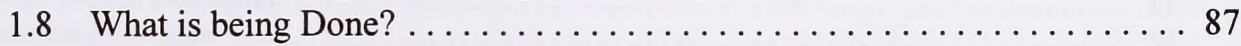

\section{Part 2 A Protected Areas Network for the Grassland}

2.1 Designing a Protected Area's Network for the Grasslands . . . . . . . 92

2.2 Identifying the Gaps in the System of Protected Lands in Alberta . . . . . . 98

2.3 Filling the Gaps in the System of Protected Lands in Alberta's Grasslands . . . . . . . . . . . . . . . . . . . . 112

2.4 Filling the Gaps in the Dry Mixedgrass Subregion $\ldots \ldots \ldots \ldots \ldots \ldots 116$

2.5 Filling the Gaps in the Foothills Fescue Subregion $\ldots \ldots \ldots \ldots \ldots 137$

2.6 Filling the Gaps in the Northern Fescue Subregion ............ 153

2.7 Filling the Gaps in the Mixedgrass Subregion .............. 172

Part 3 Conclusion

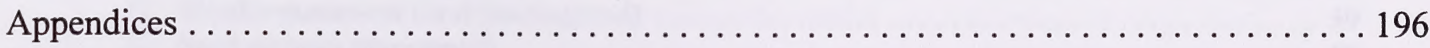

Literature Cited and Other References ................................ 205

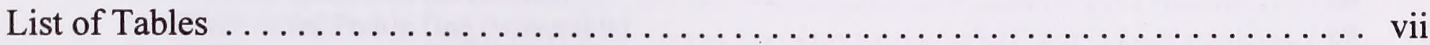

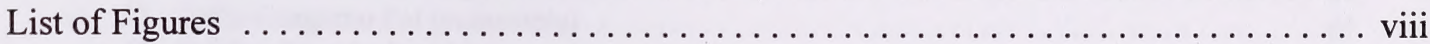

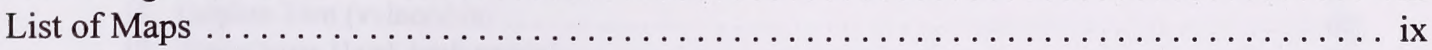

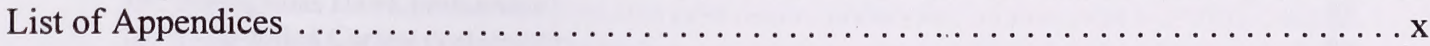




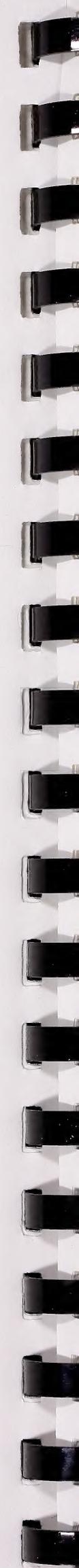




\section{Detailed Table of Contents}

Part 1 Introduction and Background 1

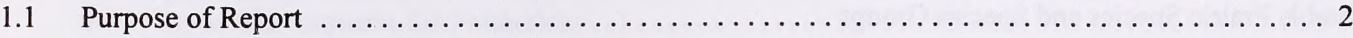

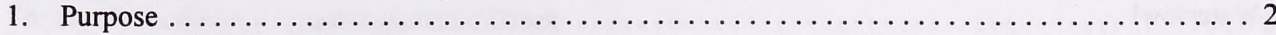

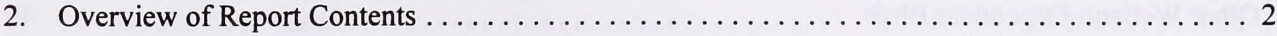

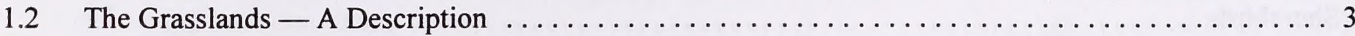

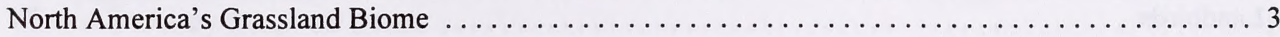

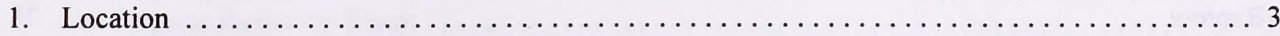

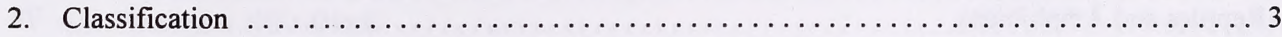

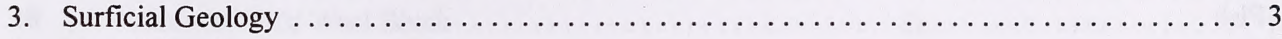

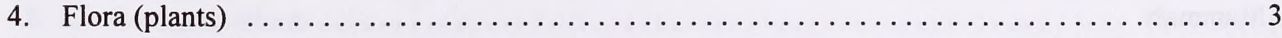

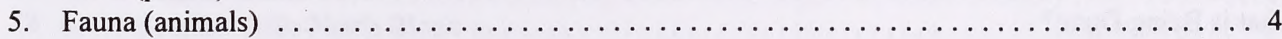

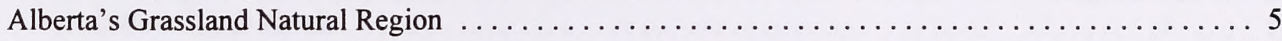

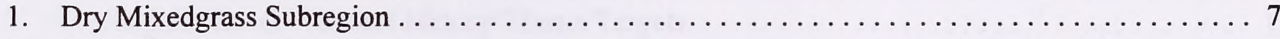

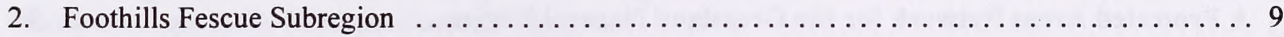

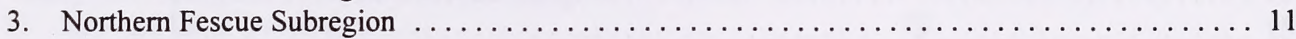

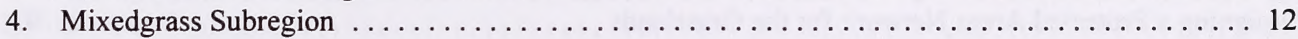

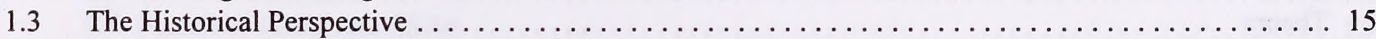

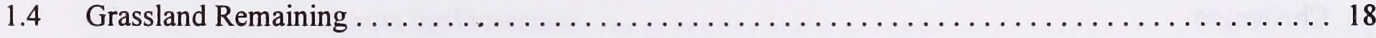

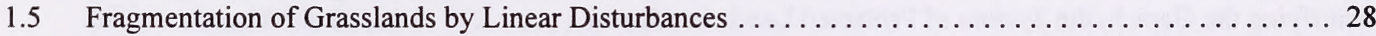

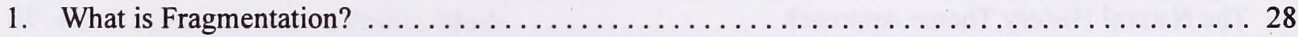

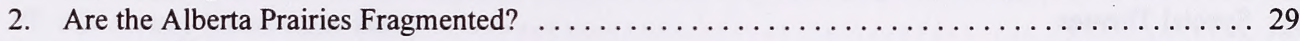

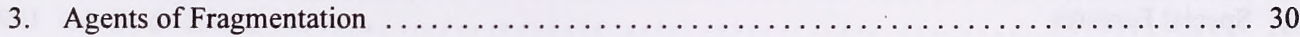

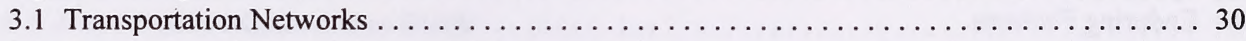

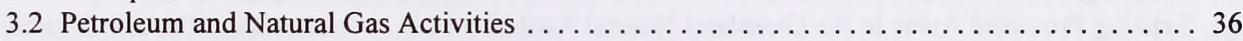

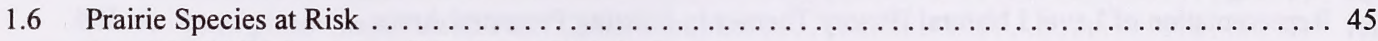

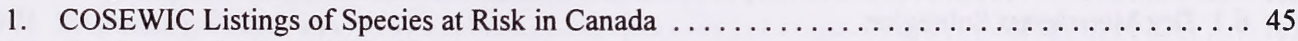

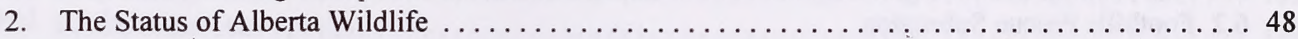

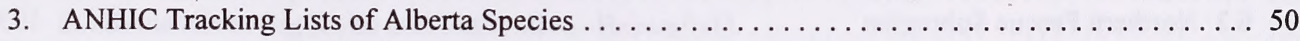

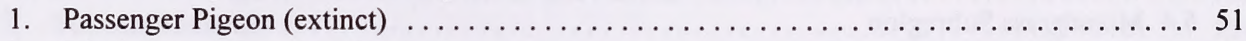

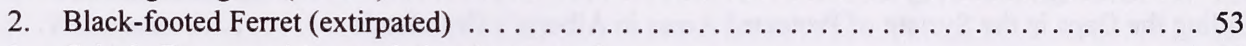

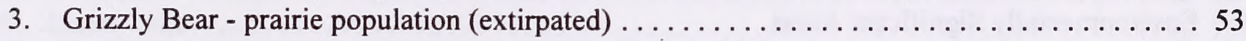

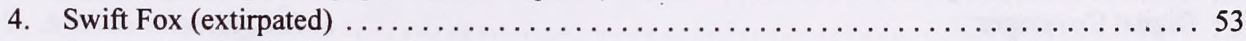

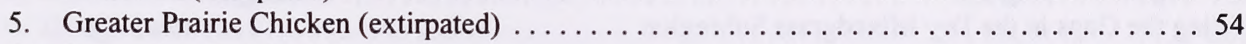

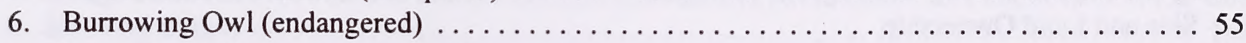

7. Loggerhead Shrike (endangered/threatened) $\ldots \ldots \ldots \ldots \ldots \ldots \ldots \ldots \ldots \ldots \ldots \ldots \ldots \ldots$

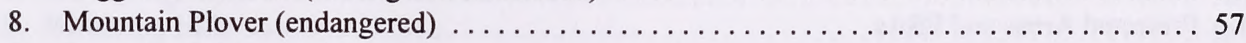

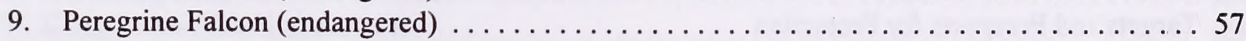

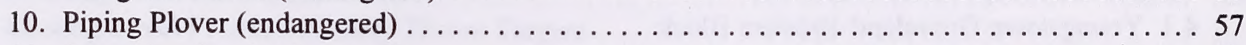

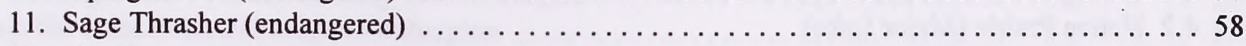

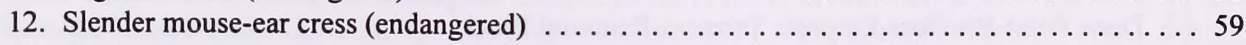

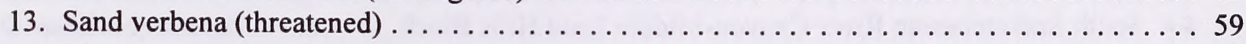

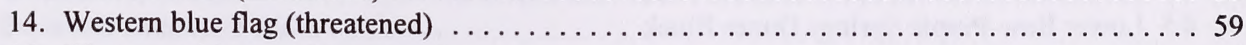

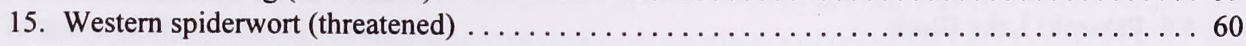

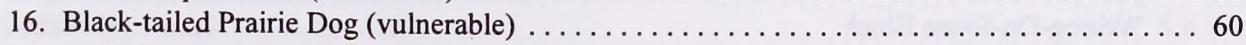

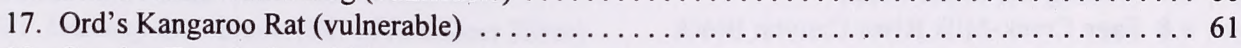

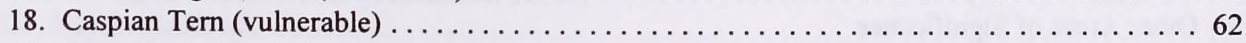

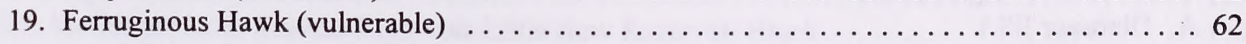

20. Long-billed Curlew (vulnerable) $\ldots \ldots \ldots \ldots \ldots \ldots \ldots \ldots \ldots \ldots \ldots \ldots \ldots \ldots \ldots \ldots \ldots \ldots \ldots$

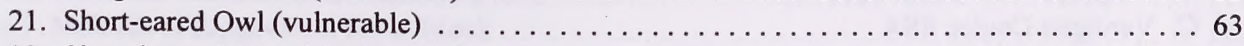

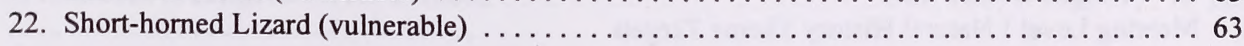




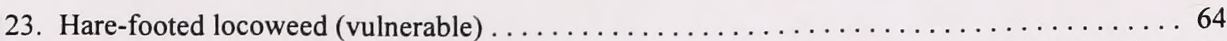

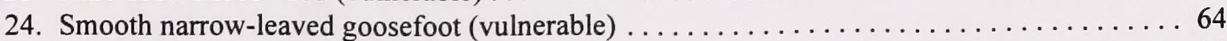

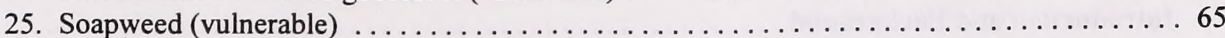

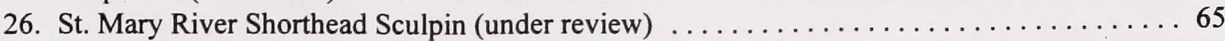

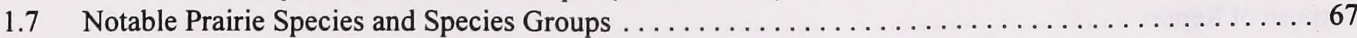

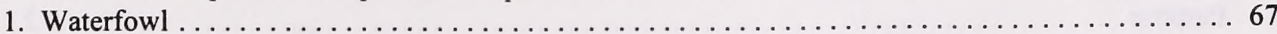

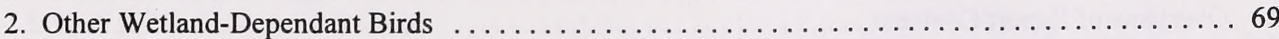

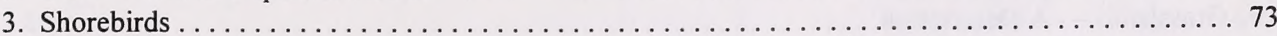

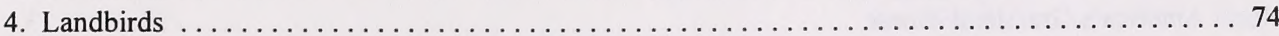

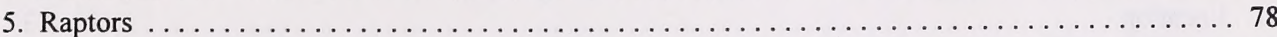

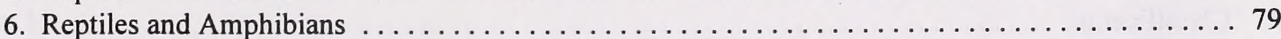

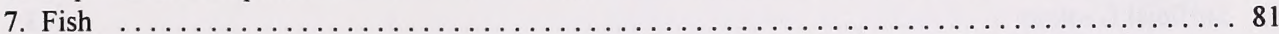

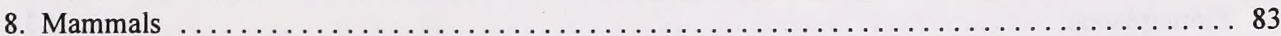

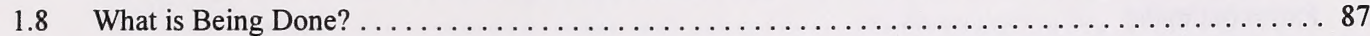

Part 2 A Protected Areas Network for the Grassland Natural Region $\ldots \ldots \ldots \ldots \ldots \ldots \ldots \ldots$. 91

$2.1 \quad$ Designing a Protected Areas Network for the Grasslands $\ldots \ldots \ldots \ldots \ldots \ldots \ldots \ldots \ldots \ldots \ldots 2$

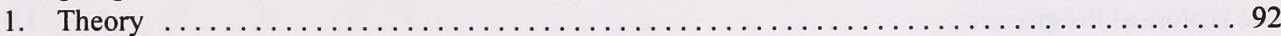

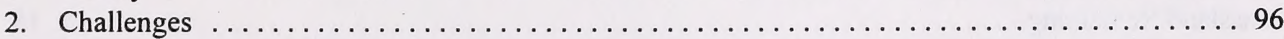

2.2 Identifying the Gaps in the System of Protected Lands in Alberta $\ldots \ldots \ldots \ldots \ldots \ldots \ldots \ldots \ldots 9$

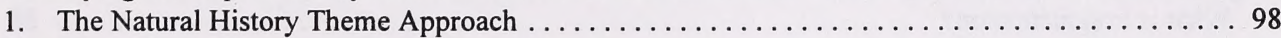

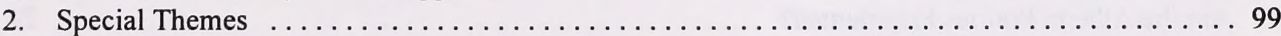

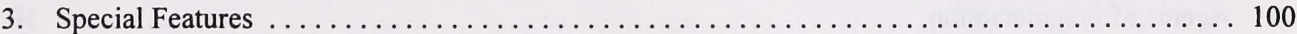

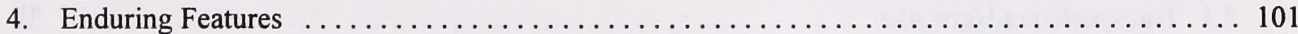

5. Existing Protected Areas in the Grassland Natural Region $\ldots \ldots \ldots \ldots \ldots \ldots \ldots \ldots \ldots \ldots \ldots$

6. Representation of Level I Natural History Themes in Existing Protected Areas . . . . . . . . . 104

6.1 Dry Mixedgrass Subregion . . . . . . . . . . . . . . . . . . . . . . . . . . 104

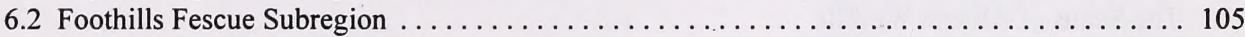

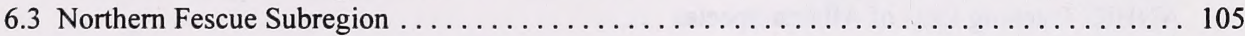

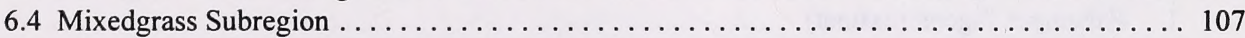

2.3 Filling the Gaps in the System of Protected Areas in Alberta's Grasslands $\ldots \ldots \ldots \ldots \ldots \ldots \ldots 112$

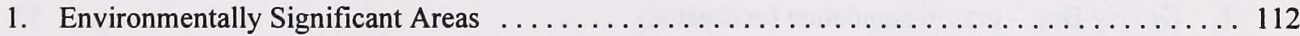

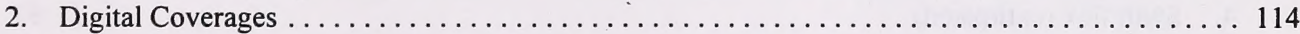

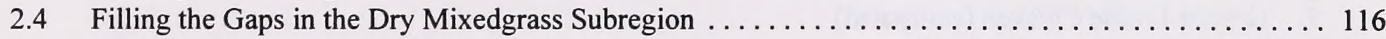

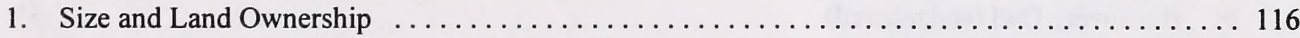

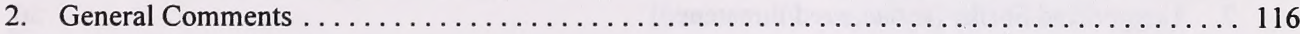

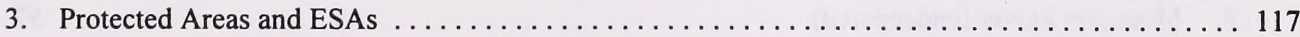

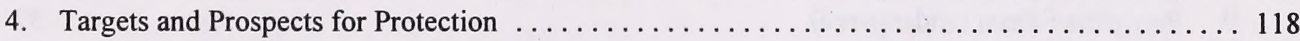

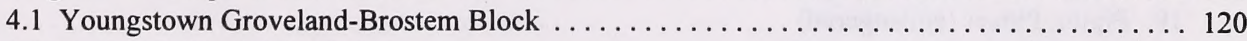

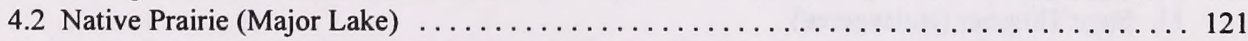

4.3 Dune Point-Bindloss-Empress Terraces-Remount Block $\ldots \ldots \ldots \ldots \ldots \ldots \ldots \ldots \ldots \ldots \ldots$

4.4 South Saskatchewan River Canyon-Middle Sand Hills Block $\ldots \ldots \ldots \ldots \ldots \ldots \ldots \ldots \ldots \ldots \ldots \ldots \ldots$

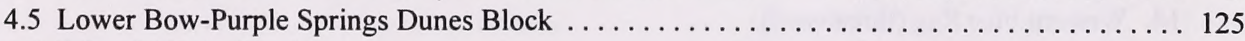

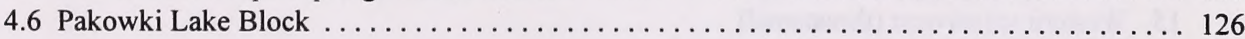

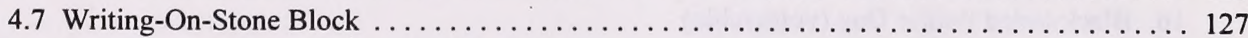

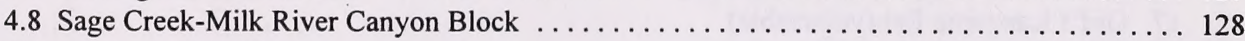

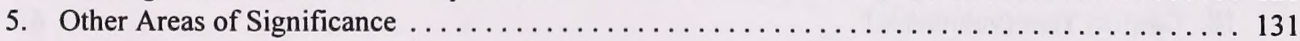

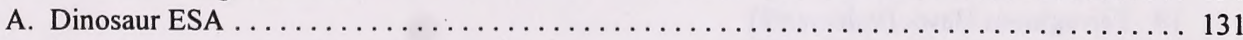

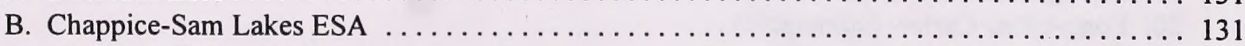

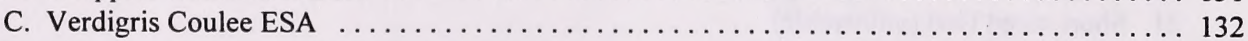

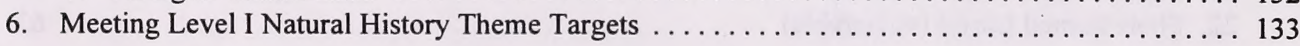


$2.5 \quad$ Filling the Gaps in the Foothills Fescue Subregion $\ldots \ldots \ldots \ldots \ldots \ldots \ldots \ldots \ldots \ldots \ldots \ldots \ldots \ldots \ldots \ldots \ldots \ldots$

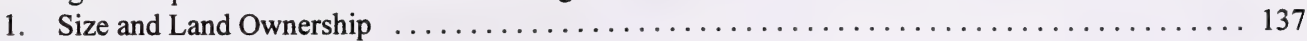

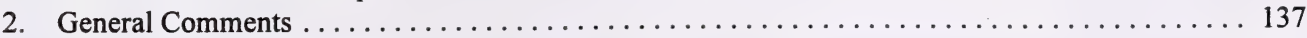

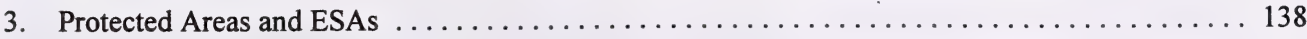

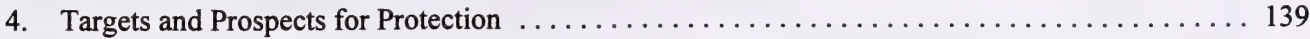

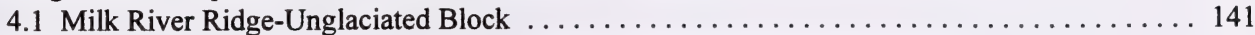

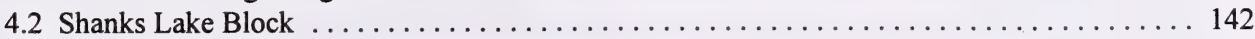

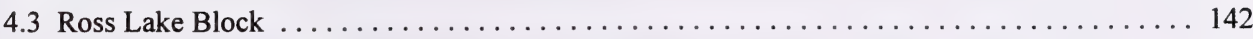

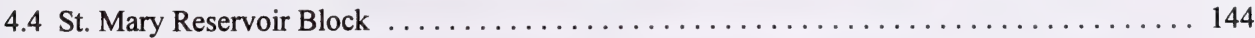

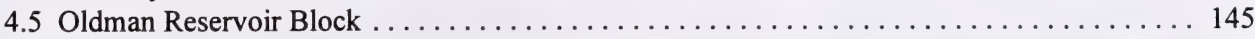

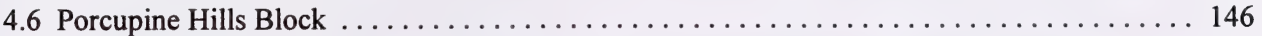

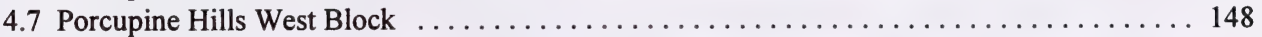

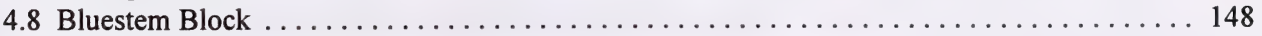

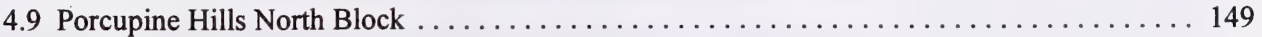

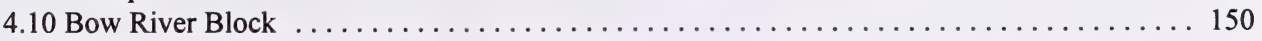

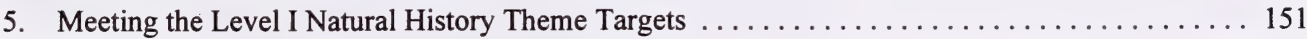

2.6 Filling the Gaps in the Northern Fescue Subregion $\ldots \ldots \ldots \ldots \ldots \ldots \ldots \ldots \ldots \ldots \ldots \ldots \ldots \ldots \ldots \ldots$

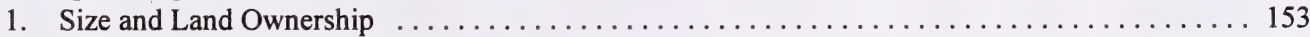

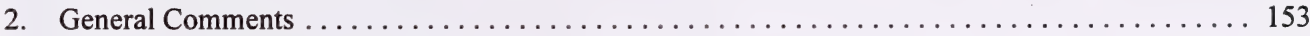

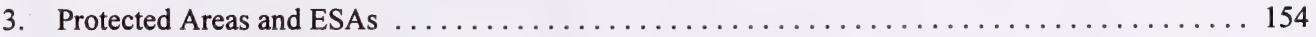

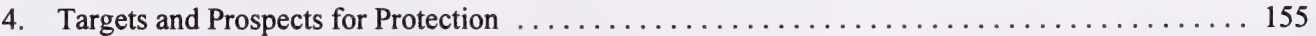

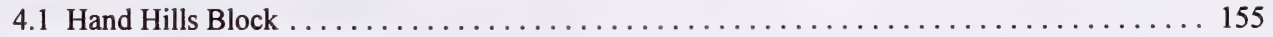

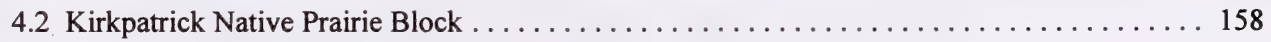

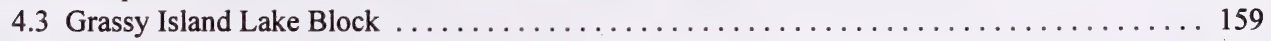

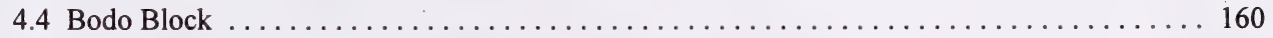

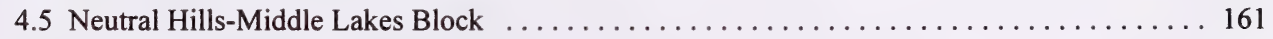

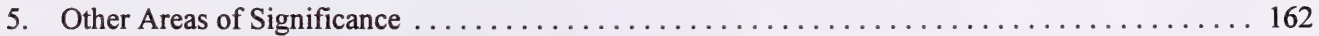

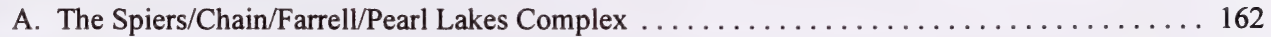

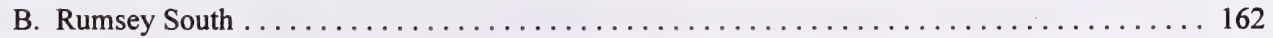

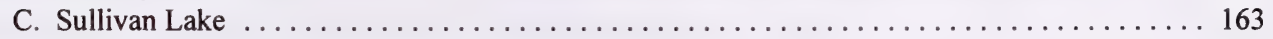

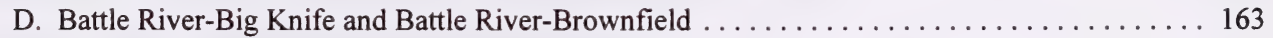

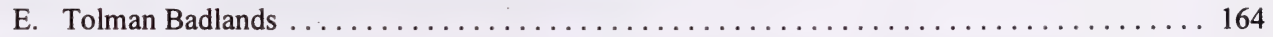

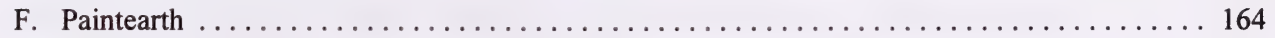

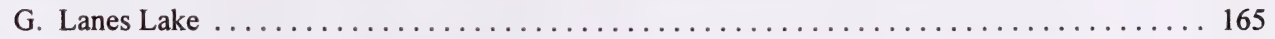

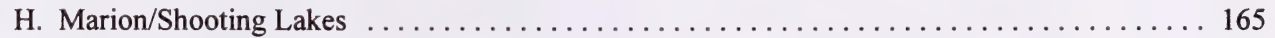

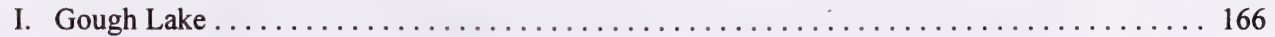

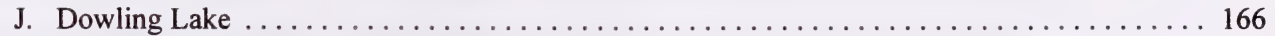

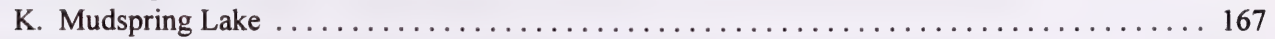

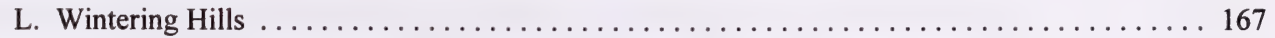

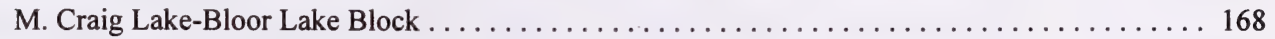

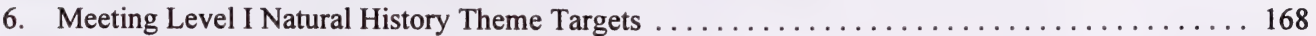

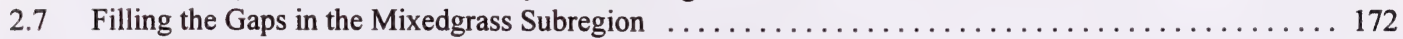

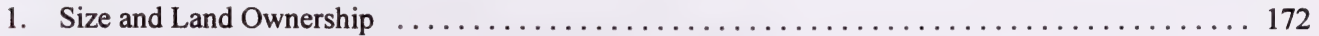

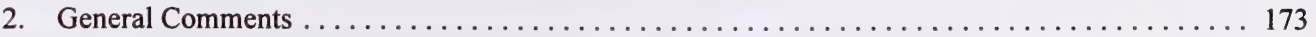

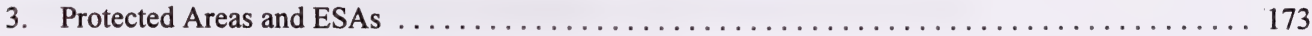

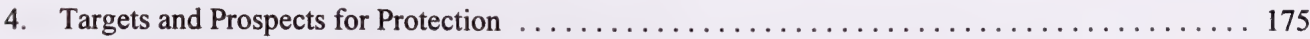

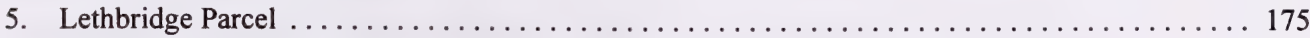

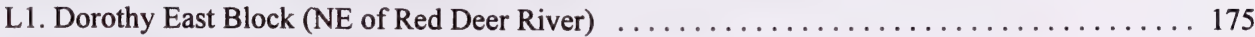

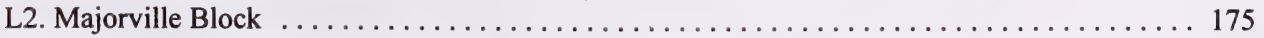

L3. McGregor Lake-Travers Reservoir-Little Bow Reservoir Block . . . . . . . . . . . . . . . . 177

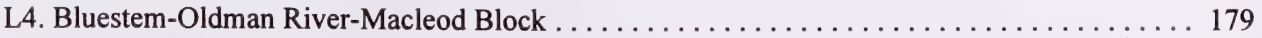

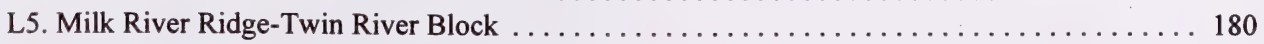


6. Other Areas of Significance Within the Lethbridge Parcel $\ldots \ldots \ldots \ldots \ldots \ldots \ldots \ldots \ldots \ldots 1$

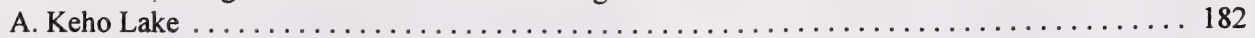

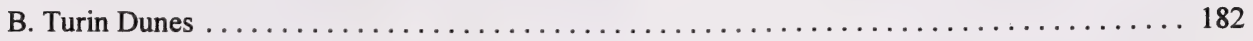

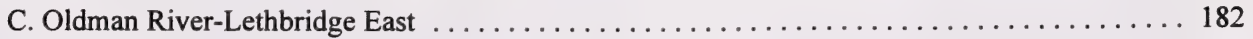

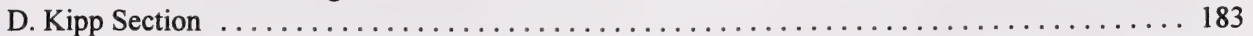

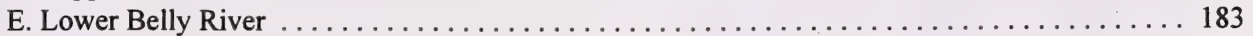

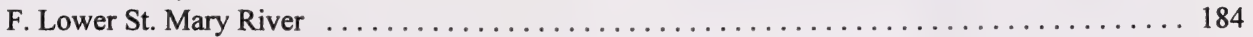

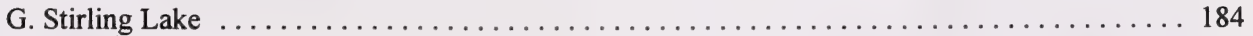

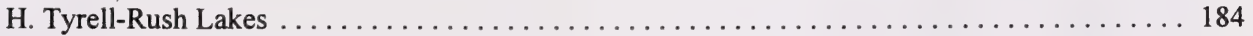

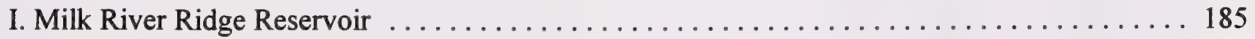

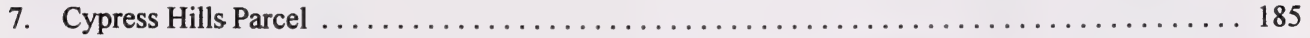

C1. Eagle Butte-Red Rock Coulee Block .......................... 185

C2. Manyberries Creek Badlands-Cypress Hills South Block $\ldots \ldots \ldots \ldots \ldots \ldots \ldots \ldots \ldots \ldots$

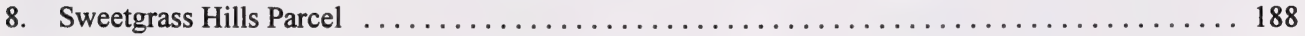

S1. Milk River-Pakowki/Pinhorn-Black Butte Block $\ldots \ldots \ldots \ldots \ldots \ldots \ldots \ldots \ldots \ldots \ldots \ldots$

9. Meeting Level I Natural History Theme Targets $\ldots \ldots \ldots \ldots \ldots \ldots \ldots \ldots \ldots \ldots \ldots \ldots$

Part 3 Conclusion ...................................................... 194

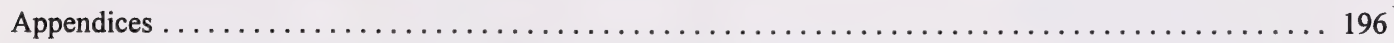

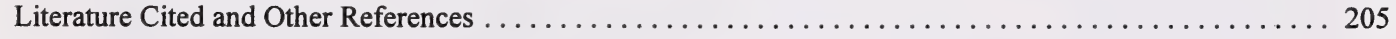




\section{List of Tables}

$\underline{\text { Page }}$

1. Sizes and proportions of the four grassland subregions $\ldots \ldots \ldots \ldots \ldots \ldots \ldots$

2. Vegetation, soils and climatic differences of the four grassland subregions $\ldots \ldots .5$

3. Estimated current area, historic area and percent decline of the prairies $\ldots \ldots \ldots 18$

4. Native prairie remaining in portions of the Grassland Natural Region of Alberta . . . 21

5. Linear distances $(\mathrm{km})$ of roads and railways in the Grassland Natural Region .... 31

6. Length and densities of wellsite roads in the Grassland Natural Region . . . . . . 32

7. Areal extent $\left(\mathrm{km}^{2}\right)$ of roads and railways in the Grassland Natural Region ...... 33

8. Proportion of the grassland subregions occupied by road density classes $\ldots \ldots \ldots 35$

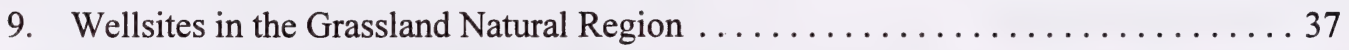

10. Proportion of the grassland subregions occupied by wellsite density classes . . . 40 40

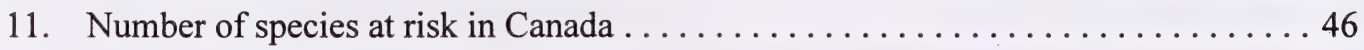

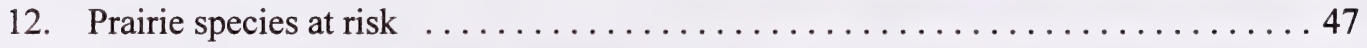

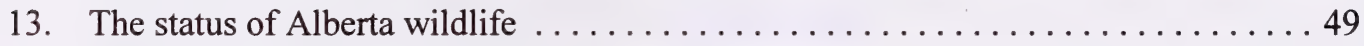

14. Species on the tracking list mapped as occurring within the Grassland

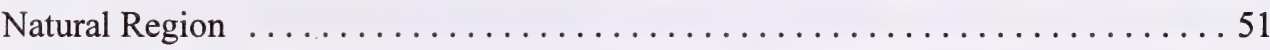

15. Burrowing Owl nest occurrence (1981-1993) by Ecoregion . . . . . . . . 56

16. High priority habitat areas for waterfowl in Alberta $\ldots \ldots \ldots \ldots \ldots \ldots \ldots . \ldots 6$

17. Areas, proportions and Level 1 NHT targets of the four grassland subregions . . . 99

18. Examples of Special Themes in the Grassland Natural Region . . . . . . . . . . 100

19. Protected areas in the Grassland Natural Region ....................... 103

20. Level 1 Natural History Theme summary for the Dry Mixedgrass Subregion . . . . . 108

21. Level 1 Natural History Theme summary for the Foothills Fescue Subregion . . . . 109

22. Level 1 Natural History Theme summary for the Northern Fescue Subregion . . . . 110

23. Level 1 Natural History Theme summary for the Mixedgrass Subregion . . . . . 111

24. Environmentally significant areas studies in the Grassland Natural Region . . . . . 113

25. Distribution, aerial extent and significance ratings of ESAs within the Grassland Natural Region ............................ 113

26. Land ownership within the Dry Mixedgrass Subregion $\ldots \ldots \ldots \ldots \ldots \ldots \ldots$

27. Amount of land per category of remaining native prairie within the

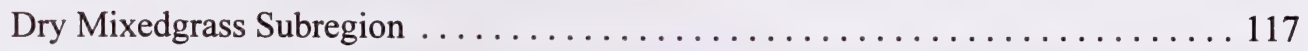

28. Occurrence of Level 1 Natural History Themes in selected blocks within

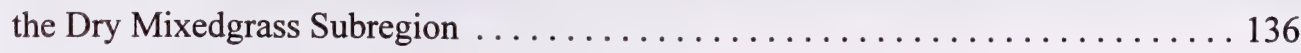




\section{List of Tables (continued)}

29. Land ownership within the Foothills Fescue Subregion . . . . . . . . . . . . 137

30. Amount of land per category of remaining native prairie within the Foothills Fescue Subregion . . . . . . . . . . . . . . . . . . . . . . 138

31. Occurrence of Level 1 Natural History Themes in selected blocks within the Foothills Fescue Subregion . . . . . . . . . . . . . . . . . . 152

32. Land ownership within the Northern Fescue Subregion . . . . . . . . . . . . 153

33. Amount of land per category of remaining native prairie within the Northern Fescue Subregion . . . . . . . . . . . . . . . . . . . 154

34. Occurrence of Level 1 Natural History Themes in selected blocks within the Northern Fescue Subregion . . . . . . . . . . . . . . . . . . . . . . . 169

35. Land ownership within the Mixedgrass Subregion $\ldots \ldots \ldots \ldots \ldots \ldots \ldots \ldots$

36. Amount of land per category of remaining native prairie within the Mixedgrass Subregion $\ldots \ldots \ldots \ldots \ldots \ldots \ldots \ldots \ldots \ldots \ldots \ldots \ldots \ldots$

37. Occurrence of Level 1 Natural History Themes in selected blocks within the Mixedgrass Subregion

38. Sizes and proportions of priority lands for Special Places Level 1 Natural History Theme targets.

\section{List of Figures}

1. Decline of the Canadian prairies (after Samson and Knopf 1994). . . . . . . . . 19

2. Native prairie remaining in Alberta's grassland subregions. . . . . . . . . . . 22

3. Satellite image of landscapes in SE Alberta, SW Saskatchewan and northern

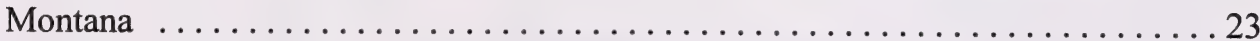

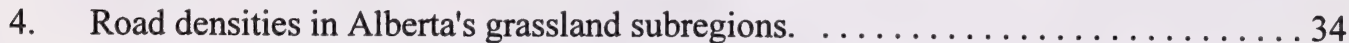

5. Proportion of the grassland subregions occupied by road density classes. . . . . . 35

6. Wellsites and wellsite densities in Alberta's grassland subregions. . . . . . . . . . 39

7. Proportion of the grassland subregions occupied by wellsite density classes. . . . 40 


\section{List of Maps}

$\underline{\text { Page }}$

Map 1. Alberta's Natural Regions and Subregions $\ldots \ldots \ldots \ldots \ldots \ldots \ldots$

Map 2. Road density classes in the Grassland Natural Region . . . . . . . . . . . . 38

Map 3. Wellsite densities (wells $/ \mathrm{km}^{2}$ ) in the Grassland Natural Region .........41

Map 4. Pipeline distribution in T20-R8-W4M ................. 43

Map 5. Known locations of rare species in the Grassland Natural Region . . . . . . . 52

Map 6. Wellsites, pipelines and access roads in CFB Suffield, Alberta . . . . . . . 106

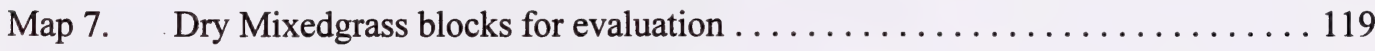

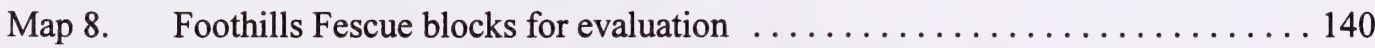

Map 9. Northern Fescue blocks for evaluation . . . . . . . . . . . . . . 157

Map 10. Mixedgrass blocks for evaluation $\ldots \ldots \ldots \ldots \ldots \ldots \ldots \ldots \ldots \ldots \ldots$

\section{Back of document:}

Map A. Land Ownership

Map B. Transportation Networks and Petroleum and Natural Gas Wellsites

Map C. Environmentally Significant Areas

Map D. Native Prairie Remaining

Map E. Contiguous Parcels of Crown Land $10 \mathrm{~km}^{2}$ and Larger

Map F. Prospects for Protection

Map G. Priorities for Special Places Level 1 Targets 


\section{List of Appendices}

\section{$\underline{\text { Page }}$}

Appendix.1. Tracking list of the vascular plant and moss species that occur within the Grassland Natural Region . . . . . . . . . . . . . 197

Appendix 2. Environmentally Significant Areas ..................... 201 


\section{PART 1}

\section{Introduction and Background}




\section{Chapter 1.1 Purpose of Report}

\section{Purpose}

This report is one of a series dealing with the province's Natural Regions and Subregions and was prepared, in part, for the Special Places Provincial Coordinating Committee (PCC). The purpose of this report is to provide the PCC with an analysis of the Grassland Natural Region from a landscape protection/biodiversity conservation perspective. This analysis will assist members of the PCC in evaluating and ranking candidate Special Places sites nominated by Albertans.

\section{Overview of Report Contents}

This report discusses the Grassland Natural Region and focuses on crown land. Chapter 1.1 provides background information on the reasons why this report was prepared. Chapter 1.2 presents a brief biophysical perspective of the grassland biome in North America and in Canada, with more detailed information for Alberta. Chapter 1.3 provides an historical perspective and Chapter 1.4 discusses the resulting amount of grassland remaining. Detailed information on ongoing fragmentation of grassland ecosystems through linear disturbances is presented in Chapter 1.5. Chapters 1.6 and 1.7 review the results of historical trends on grassland species.

The prairies have changed dramatically over the last 75 to 100 years under the cumulative effects of roadways, urbanization, cultivation, livestock grazing, petroleum and natural gas development, mining, hydroelectric dams, irrigation developments, electrical transmission lines and other developments. These are all a necessary part of modern society and help to support the social and economic needs and other demands of its human population - locally, nationally and internationally. Human activity, however, has altered species, landscapes and the natural ecological processes of the prairies.

Many individuals, organizations, agencies and industries recognize the value of restoring, reclaiming and rehabilitating damaged or degraded prairie features, ecosystems and landscapes. Considerable effort and funds are devoted to this cause and progress has been made. Some aspects that are being considered in the task of conserving and restoring native grasslands are discussed in Chapter 1.8.

Along with restoration of damaged or degraded areas, there is a need to protect examples of prairie ecosystems. This is dealt with in considerable detail in Part 2. The philosophy behind designing a protected area's network on provincial crown lands for the grasslands of Alberta is presented in Chapter 2.1. Chapter 2.2 outlines where gaps occur in the system of protected lands in the four grassland subregions in the province. Chapter 2.3 describes the process used to help focus on provincial crown lands that have the potential to fill identified gaps. The final four chapters (2.4 to 2.7) deal with each of the subregions in the Grassland Natural Region and the locations of the best candidate areas to be considered for protection. 


\section{Chapter 1.2 The Grasslands - A Description}

\section{North America's Grassland Biome}

\section{Location}

The grasslands of the Great Plains of North America originally covered nearly 2.6 million $\mathrm{km}^{2}$ (one million square miles) within the interior of North America. This is roughly $14 \%$ of the continent's land mass north of Mexico. They stretched south from the boreal forests of Manitoba, Saskatchewan and Alberta to the arid semi-deserts of the southwest United States and Mexico. From the foothills of the Rocky Mountains they stretched east to western Minnesota, Iowa and Missouri (Ostlie et al. 1996, p11, Wickett et al. 1992, p61).

\section{Classification}

Traditionally, the grasslands of the Great Plains have been broken into three major vegetation regions: tallgrass, mixedgrass, and shortgrass prairie. Coupland and Brayshaw (1953) added a fourth, the fescue prairie. Many authors (eg. Ostlie et al.1996) incorporate the fescue prairie within the mixedgrass prairie vegetation region, probably because it is relatively small in aerial extent.

\section{Surficial Geology}

Cretaceous seas originally covered much of the Great Plains, resulting in a generally flat to rolling topography (Ostlie et al. 1996). The northern portion of the area was extensively glaciated with the result that its surficial materials are primarily glacial in origin. Deposits of varying thickness are found in the form of ground moraine, rolling to hummocky moraine, or have been modified by water action to form glaciolacustrine, glaciofluvial or recent fluvial deposits. There are small areas of exposed bedrock and dunes. In areas, bedrock outcrops are a major component of the landscape. The glaciated northern terrain contrasts considerably with the rolling to dissected, unglaciated landscapes found in the southern part of the Great Plains (ibid.).

\section{Flora (Plants)}

Herbaceous species (e.g., composites, legumes, grasses, sedges) dominate the vascular flora of the Great Plains. Compared to adjacent regions in North America, "the total number of native vascular plant species occurring in the Plains as a whole is depauperate (depauperate area is one that has relatively few species. One estimate for the entire Plains region is five thousand species" (Ostlie et al. 1996, p38). 


\section{Fauna (Animals)}

The indigenous wildlife community of the Great Plains is one of the most distinctive in North America. It is also somewhat "depauperate in species when compared with adjoining areas" (Ostlie et al. 1996, p39). Although relatively low in numbers of species, the Great Plains is known for its historic assemblage of large mammals (e.g., bison, Pronghorn, elk, deer) which occurred in immense numbers.

The Plains have about 10 to 18 endemic mammals (Ostlie et al. 1996). Ricklefs (1979, p869) defines endemic species as those "confined and native to a certain region." Principally, the endemic mammals of the Plains are the White-tailed Jack Rabbit, Thirteen-lined Ground Squirrel, Franklin's Ground Squirrel, Black-tailed Prairie Dog, Plains Pocket Gopher, Olivebacked Pocket Mouse, Plains Pocket Mouse, Plains Harvest Mouse, Prairie Vole, Swift Fox, Black-footed Ferret and Pronghorn.

Large mammalian predators such as the Grizzly Bear and wolf have been largely extirpated from the Great Plains (i.e., they no longer occur in the area, but have not been eliminated from their entire range). Today, the principal mammalian predators are Red Fox, Coyote, American Badger, Long-tailed Weasel and skunk. "Rodents comprise the most diverse taxonomic group of mammals in the Great Plains" (Ostlie et al. 1996, p40). The Black-tailed Prairie Dog provided and prey for Black-footed Ferret, American Badger, Ferruginous Hawk and Golden Eagle and nesting habitat for Burrowing Owl. Black-tailed Prairie Dogs however have been extirpated from much of their former range.

The Great Plains provides nesting habitat about $75 \%$ of the bird species that breed within the United States (Ostlie et al. 1996, p41). The following species are listed as endemic to the Plains: Ferruginous Hawk, Mountain Plover, Long-billed Curlew, Marbled Godwit, Wilson's Phalarope, Franklin's Gull, Sprague's Pipit, Cassin's Sparrow, Baird's Sparrow, Lark Bunting, McCown's Longspur and Chestnut-collared Longspur (ibid.). According to Breeding Bird Survey (BBS) data, "The largest number of grassland species are found in the northern Great Plains, especially in the Dakotas, Montana, and adjacent Canadian provinces. [Notable is southeast Alberta and southwest Saskatchewan]. The fewest species are found from the Rocky Mountains westward and in most of eastern North America" (Sauer et al. 1996).

Moving north, the diversity of reptile and amphibian species in the Great Plains decreases. In the prairies of Texas there are over 100 reptile and amphibian species documented while only eight are known from the prairies of Alberta (Ostlie et al. 1996, p42). Several fish species "evolved within the characteristically turbid waters of the larger Plains rivers" (ibid., p43). Many of these species are endemic to Plains streams and include: Pallid Sturgeon, Sturgeon Chub, Western Silvery Minnow, Plains Minnow, Goldeye, Flathead Chub, Chub Shiner and Plains Killifish (ibid.). 


\section{Alberta's Grassland Natural Region}

Alberta's landscapes are divided into six natural regions based on broad differences in landscape patterns (Alberta Environmental Protection 1994b). These regions are further divided into a total of 20 subregions, based on recurring patterns found within the larger natural region. The Grassland Natural Region is located in southern Alberta and consists of four subregions (Map 1).

The Grassland Natural Region covers about 96425 sq. km., or about 14.5\% of Alberta (Table 1). The Dry Mixedgrass Subregion is the largest of the four grassland subregions, occupying nearly $47,000 \mathrm{~km}^{2}$ or about $7 \%$ of the area of Alberta.

Table 1. Sizes and proportions of the four grassland subregions (Alberta Environmental Protection 1994b).

\begin{tabular}{|c|c|c|c|}
\hline Subregion & Area $\left(\mathrm{km}^{2}\right)$ & $\begin{array}{c}\text { Subregion as \% } \\
\text { of Alberta }\end{array}$ & $\begin{array}{c}\text { Subregion as \% } \\
\text { of region }\end{array}$ \\
\hline Dry Mixedgrass & 46,976 & 7.1 & 48.7 \\
\hline Mixedgrass & 19,177 & 2.9 & 19.9 \\
\hline Northern fescue & 15,385 & 2.3 & 15.9 \\
\hline Foothills fescue & 14,888 & 2.2 & 15.5 \\
\hline Subtotal & 96,425 & 14.5 & 100 \\
\hline Size of Alberta & & $662,948 \mathrm{~km}^{2}$ & \\
\hline
\end{tabular}

The four subregions are separated primarily based on differing vegetation, climate and soils as shown in Table 2.

Table 2. Vegetation, soils and climatic differences of the four grassland subregions (Achuff 1992)

\begin{tabular}{|l|l|l|l|}
\hline \multicolumn{1}{|c|}{ Subregion } & \multicolumn{1}{|c|}{ Vegetation } & \multicolumn{1}{c|}{ Soils } & \multicolumn{1}{c|}{ Climate } \\
\hline Dry Mixedgrass & $\begin{array}{l}\text { western wheatgrass } \\
\text { blue grama } \\
\text { spear grass }\end{array}$ & $\begin{array}{l}\text { brown Chernozems } \\
\text { Solonetzics }\end{array}$ & $\begin{array}{l}\text { few chinooks } \\
\text { warmest \& driest }\end{array}$ \\
\hline Mixedgrass & $\begin{array}{l}\text { northern wheat grass } \\
\text { porcupine grass }\end{array}$ & dark brown Chernozems & $\begin{array}{l}\text { more chinooks } \\
\text { cooler \& moister }\end{array}$ \\
\hline Northern fescue & $\begin{array}{l}\text { porcupine grass } \\
\text { rough fescue } \\
\text { June grass }\end{array}$ & $\begin{array}{l}\text { dark brown \& black Chernozems } \\
\text { Solonetzics }\end{array}$ & $\begin{array}{l}\text { few chinooks } \\
\text { colder \& moister }\end{array}$ \\
\hline Foothills fescue & $\begin{array}{l}\text { oatgrasses } \\
\text { rough fescue } \\
\text { Idaho fescue }\end{array}$ & $\begin{array}{l}\text { dark brown \& black Chernozems } \\
\text { few Solonetzics }\end{array}$ & $\begin{array}{l}\text { more chinooks } \\
\text { milder winters }\end{array}$ \\
\hline
\end{tabular}




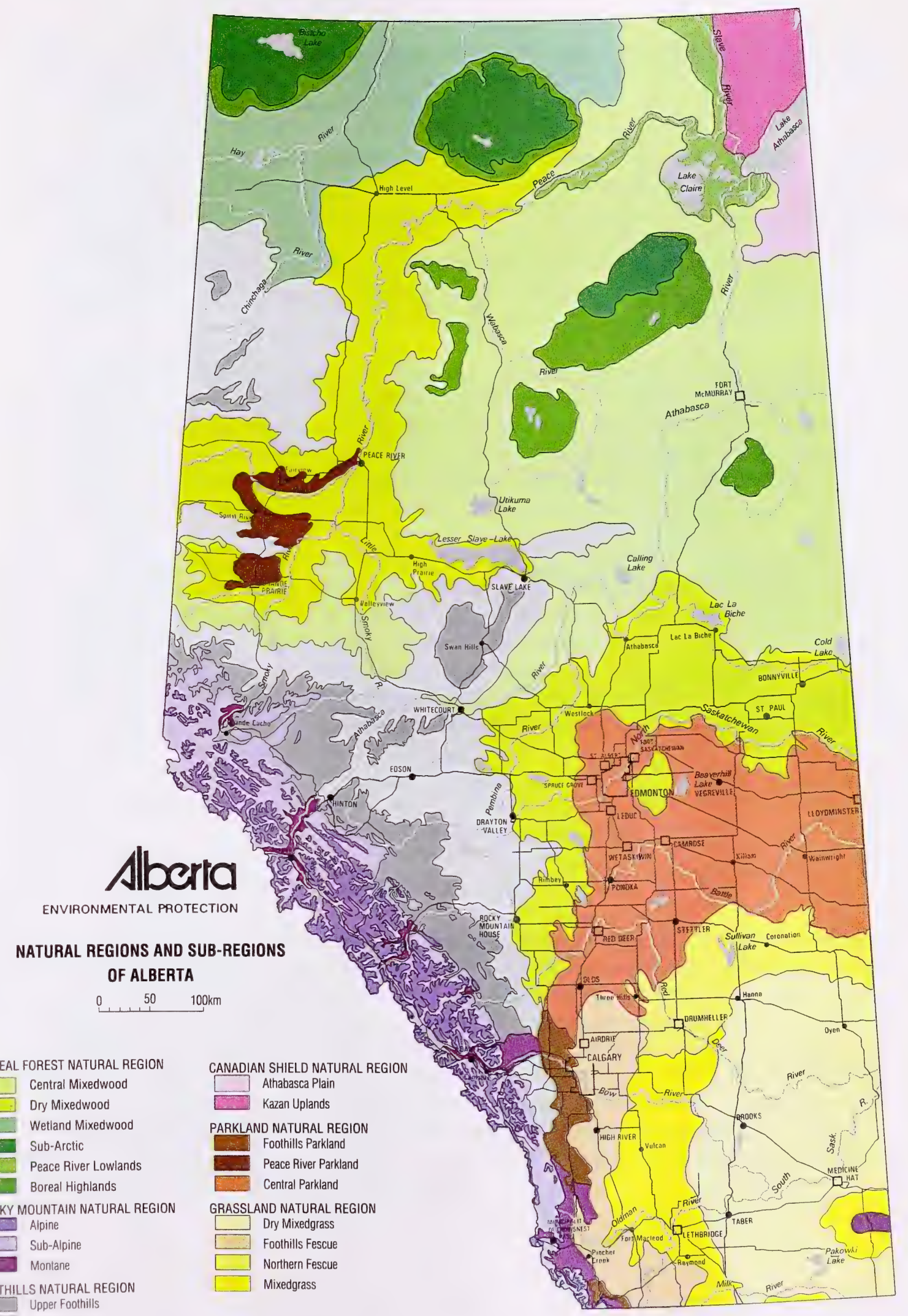

Produced by Alberta Parks Services, Management Support Division. 1994

Map 1. Alberta's Natural Regions and Subregions 


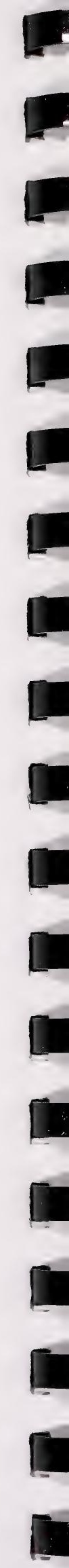


The following description of Alberta's Grassland Natural Region is taken from Natural Regions and Subregions of Alberta, A Revised Classification for Protected Areas Management (Achuff 1992 - revised and updated December 1994):

The Grassland Natural Region occupies a broad area of southern Alberta. It extends west to the Rocky Mountains and north to the southern edge of the Parkland Natural Region in central Alberta. The region is a flat to gently rolling plain with a few major hill systems. Extensive, thick glacial till deposits cover most of the area. The diversity of the uplands is increased by numerous areas of fine-textured materials laid down in proglacial lakes and coarse-textured deposits in dune fields and outwash plains, both of which are associated with proglacial lake basins.

Rivers in the Grassland Natural Region are part of either the Saskatchewan River or Missouri River systems. Where valleys are carved deeply into bedrock, badlands have developed. Numerous coulees and ravines are associated with these river valley systems. Seven exposures of igneous rock, all within the Milk River drainage, are the only igneous exposures in the grasslands of western Canada. With the exception of these isolated igneous outcrops, bedrock exposures are all of sedimentary rocks and commonly occur along stream valleys.

The Grassland Natural Region contains four Subregions - Dry Mixedgrass, Mixedgrass, Northern Fescue, and Foothills Fescue. These Subregions are separated primarily based on climatic, soils and vegetational factors. The Dry Mixedgrass Subregion is most extensive, occurring from the U.S. border, north and west to the Mixedgrass and Northern Fescue Subregions. The Mixedgrass Subregion occurs generally west of the Dry Mixedgrass Subregions. The Northern Fescue and Foothills Fescue Subregions occur in narrow belts along the northern and western margins of the Dry Mixedgrass and Mixedgrass Subregions.

\section{Dry Mixedgrass Subregion}

\section{Geology and Landforms}

The topography of the Dry Mixedgrass Subregion is generally subdued with only a few minor uplands. The predominant landform is a low-relief ground moraine but there are significant areas of hummocky moraine, glaciofluvial outwash, glaciolacustrine sand plains, fine-textured glaciolacustrine lake deposits, and eroded plains. Elevations range from $600 \mathrm{~m}$ near Empress to more than $1300 \mathrm{~m}$ on the lower slopes of the Cypress Hills, Sweetgrass Hills. Although permanent streams are relatively rare, the ones that do exist are well defined. The Subregion is drained by several major rivers that have carved deeply into the bedrock in some places. This has exposed Cretaceous shales and sandstones, creating extensive badlands in some areas. Drainage is to the Missouri River system via the Milk River and to the Saskatchewan River system via all of the other rivers in the subregion. 


\section{Climate}

Climatically, the Dry Mixedgrass Subregion is the warmest and driest in Alberta. It has a typical continental climate with cold winters, warm summers and low precipitation. Because of the warm summer temperatures and a high average wind speed, the rate of evaporation is high throughout the summer months. There is high daily and seasonal temperature variation. It is characterized by a mean annual temperature of $4^{\circ} \mathrm{C}$ and a growing season (May - September) mean of about $16^{\circ} \mathrm{C}$. The mean winter temperature is typically about $-7^{\circ}$ and the mean summer temperature is about $16^{\circ} \mathrm{C}$.

Total annual precipitation is typically around $260-280 \mathrm{~mm}$ and summer precipitation is lowest of any Subregion in Alberta. Compared to other Subregions, the Dry Mixedgrass Subregion has a high year-to-year precipitation variability. Spring is the wettest season with about two-thirds of the annual precipitation falling as rain, the peak occurring in June. The amount of snow cover is relatively low as is the number of days of continuous snow cover. Chinooks are most common along the western border of the subregion where there are more than 30 chinook days per year.

\section{Soils}

The characteristic soils of the Dry Mixedgrass Subregion are Dark Brown Chernozems. Brown Solonetz soils are common in the extreme southeast of the subregion and in a large area north of Dinosaur Provincial Park.

\section{Vegetation}

The name "Mixedgrass" comes from the predominance of both short and mid-height grasses. The most widespread are the mid-grasses, Stipa spp. (spear grass), Agropyron smithii (western wheat grass) and Koeleria micrantha (June grass) and the short grass, Bouteloua gracilis (blue grama). Agropyron dasystachyum (northern wheat grass) and Stipa curtiseta (western porcupine grass) are characteristic of moister sites within the Subregion.

Most Mixedgrass vegetation is a Stipa comata - Bouteloua gracilis community with Agropyron smithii and $A$. dasystachyum also important in hummocky moraine areas. Fine-textured soils in glacial lake basins are characterized by the Agropyron dasystachyum - Koeleria macrantha (northern wheat grass - June grass) community. Solonetzic soils are typically occupied by the Agropyron smithii - Bouteloua gracilis (western wheat grass - blue grama) community.

The most widespread vegetation of sand dune areas is dominated by Stipa comata (spear grass), Calamovilfa longifolia (sand grass), Koeleria macrantha (June grass) and a variety of low shrubs including Artemisia cana (sagebrush), Elaeagnus commutata (silverberry), Symphoricarpos occidentalis (western snowberry) and Rosa acicularis (prickly rose).

Although much of the natural vegetation of the Dry Mixedgrass Subregion has been replaced by agricultural crops, extensive areas of native rangeland remain that are managed primarily for grazing by domestic livestock. 


\section{Wildlife}

The Dry Mixedgrass Subregion contains the greatest number of animal species of any Subregion of the Grassland Natural Region. Many, especially those of sand dunes areas and the extreme southeastern part, occur no where else in Alberta. A few are absent or local in the rest of Canada.

On the upland plains, characteristic species of more heavily grazed areas include Horned Lark, McCown's Longspur, Chestnut-collared Longspur and Richardson's Ground Squirrel. Species of lightly grazed areas include Baird's Sparrow, Sprague's Pipit, Sharp-tailed Grouse, and Upland Sandpiper. Western Meadowlark and White-tailed Jack Rabbit are examples of species that tolerate a broad spectrum of grazing conditions.

Sage Grouse, Lark Bunting, Brewer's Sparrow and Pronghorn show an affinity for sagebrush flats in the uplands and valley bottoms.

Sand plain and dune areas, because they are so out-of-character with the surrounding landscape, contain many rare and local species that are restricted to these habitats, including Ord's Kangaroo Rat and Western Hognose Snake. Wider ranging species that also occur here include Sharptailed Grouse, Grasshopper Sparrow and Mule Deer.

Riparian shrublands and forests support a diverse animal community. These include Brown Thrasher, Gray Catbird, Yellow-breasted Chat, Mourning Dove, Northern Flicker, House Wren, Northern Oriole, Deer Mouse, Nuttall's Cottontail, and White-tailed Deer.

Rock outcrops and badlands are local but significant to a number of birds as nesting habitat including Golden Eagle, Rock Wren, Ferruginous Hawk, Prairie Falcon and Mountain Bluebird.

Marshes and wetlands are important habitat for many species of birds both breeding and migrating. Oxbow lakes of meandering streams provide key habitat for breeding amphibians including Chorus Frog, Leopard Frog, Plains Spadefoot Toad and garter snakes.

\section{Foothills Fescue Subregion}

\section{Geology and Landforms}

The Foothills Fescue Subregion occurs largely on morainal, glaciolacustrine and outwash deposits along the lower flanks of the Foothills Geologic Belt, the Porcupine Hills and onto the adjacent plains area. They occur primarily as a narrow band between the Mixedgrass Subregion and the Foothills Parkland Subregion, although in some areas Foothills Grassland merges directly into the Montane Subregion of the Rocky Mountain Region. There are disjunct areas on the lower slopes of the Sweetgrass Hills and on unglaciated loess deposits on the plateau of the Cypress Hills and immediately adjacent plains. The largest area of this latter type is on the Milk River Ridge. 
Elevations in this subregion are much higher than in the other two grassland subregions. These range up to $1400 \mathrm{~m}$ in parts of the Cypress Hills.

A small portion of this subregion, in the Milk River Ridge and Cypress Hills areas, drains into the Milk River system. The rest is part of the Saskatchewan River system.

\section{Climate}

The climate of the Foothills Fescue Subregion differs from that of the Northern Fescue Subregion in having a greater frequency of chinooks and thus, a milder winter climate. There is also greater snowfall in late winter and early spring. The majority of precipitation falls during the growing season.

The mean annual precipitation ranges from $650 \mathrm{~mm}$ in the far south to about $500 \mathrm{~mm}$ in the north. The mean May - September precipitation is $290 \mathrm{~mm}$. The mean May - September temperature is $11^{\circ}$ to $13^{\circ} \mathrm{C}$. The mean annual temperature is $3^{\circ} \mathrm{C}$ and the frost-free period averages 90 days.

\section{Soils}

The soils of this subregion are predominantly Dark Brown and Black Chernozems. Solonetzic soils are not important in the Foothills Fescue Subregion.

\section{Vegetation}

The Foothills Fescue grasslands are dominated by Festuca scabrella (rough fescue), $F$. idahoensis (Idaho fescue), Danthonia parryi (Parry's oatgrass) and Danthonia californica (intermediate oatgrass). Associated grasses include Koeleria macrantha, Agropyron dasystachyum, Stipa curtiseta, S. columbiana (Columbia needle grass), Poa cusickii (Cusick's bluegrass) and Helictotrichon hookeri. In the Cypress Hills, Danthonia parryi is rare and Agropyron trachycaulum is common. Potentilla fruticosa (shrubby cinquefoil) is a locally dominant shrub on rapidly drained sites along the foothills and on moist sites in the Cypress Hills, where it has increased with grazing pressure on the herbaceous species.

These grasslands have a greater variety and cover of forbs than does the Northern Fescue Subregion. Dominant species include: Geranium viscosissimum (sticky geranium), Anemone patens (prairie crocus), Lithospermum ruderale (woolly gromwell), Galium boreale, Thermopsis rhombifolia (golden bean), Artemisia ludoviciana (prairie sagewort), Hedysarum alpinum (American sweet vetch), Delphinium bicolor (low larkspur), Ranunculus cardiophyllus (heartleaved buttercup), Dodecatheon spp. (shooting star), and Lomatium triternatum (western wild parsley). Balsamorhiza sagittata (balsam-root) is characteristic of steep slopes of the foothills portion but is absent in the Cypress Hills.

Many species occur in the Foothills Fescue Subregion that are not found in the Northern Fescue Subregion. These include Danthonia parryi, Agropyron spicatum, Festuca idahoensis, Stipa 
columbiana, Geranium viscosissimum, Lupinus sericeus, Besseya wyomingensis, Lomatium triternatum, Bupleurum americanum, Perideria gairdneri, Lithospermum ruderale and Conimitella williamsii.

Populus angustifolia (narrow-leaved cottonwood) woodlands occur on fluvial terraces of the Oldman, Belly, Waterton, and St. Mary's rivers. These are generally less extensive than those in the Mixedgrass Subregion.

\section{Wildlife}

The fauna of the Foothills Fescue Subregion is depauperate compared with the other Subregions of the Grassland Natural Region. Upland wildlife is most diverse on the extensive plateaus of the Cypress Hills and the Milk River Ridge.

Wildlife in the forests and shrublands of the southwestern rivers is similar to that of the Milk River in the Mixedgrass Subregion. Along the western edge of the Foothills Fescue Subregion, some Rocky Mountain species occur.

\section{Northern Fescue Subregion}

\section{Geology and Landforms}

Topographically, the Northern Fescue Subregion is characterized by gently rolling terrain. The most common landforms are low-relief ground moraine and hummocky moraine. Areas of outwash and sand plains, dune fields, and fine-textured glaciolacustrine deposits occupy a smaller but significant amount of the landscape. Eroded plains are important in the Sullivan Lake area. The lowest elevations are in the eastern parts of the Subregion.

Stream drainage is part of the Saskatchewan River system except a large area of internal drainage in the Sounding Creek basin. Few stream valleys dissect the subregion but those with permanent flow are usually well-incised.

\section{Climate}

The climate of the Northern Fescue Subregion is transitional between the Mixedgrass and Central Parkland subregions. The mean May - September temperature is $14^{\circ} \mathrm{C}$ and the frost-free period is about 90 days. Mean annual precipitation is about $400 \mathrm{~mm}$, with mean May September precipitation about $280 \mathrm{~mm}$.

\section{Soils}

The predominant soils are Dark Brown and Black Chernozems, with Brown Solonetz soils extending through the centre of the subregion in a broad band north of Hanna. 


\section{Vegetation}

The grasslands of this subregion are dominated by Festuca scabrella (rough fescue), with Koeleria cristata, Stipa curtiseta, Agropyron trachycaulum, and Helictotrichon hookeri (Hooker's oatgrass) also important. Common forbs include Anemone patens (prairie crocus), Artemisia ludoviciana (prairie sagewort), Cerastium arvense (mouse-ear chickweed), Linum lewisii (wild blue flax), Erigeron glabellus (fleabane), Galium boreale (northern bedstraw), Campanula rotundifolia (harebell) and Geum triflorum (old man's whiskers).

Sand dune areas contain a mixture of Festuca scabrella grasslands with scattered shrubs of Elaeagnus commutata or thickets of Rosa spp. and Symphoricarpos occidentalis.

\section{Wildlife}

No animal species are restricted to the Northern Fescue Subregion and the composition is similar to that of the Mixedgrass Subregion. Generally, species that favour lightly to moderately grazed Northern Fescue grassland also favour lightly grazed Mixedgrass areas. These include Baird's Sparrow, Sprague's Pipit, Upland Sandpiper and Sharp-tailed Grouse. With heavy grazing, species more typical of the Mixedgrass Subregion increase, including Horned Lark, Chestnutcollared Longspur and Richardson's Ground Squirrel. Species more characteristic of the Northern Fescue Subregion than the Mixedgrass Subregion include Savannah Sparrow and Thirteen-lined Ground Squirrel.

\section{Mixedgrass Subregion}

The Mixedgrass Subregion is similar to the Dry Mixedgrass Subregion in many features. Those that differentiate it from the Dry Mixedgrass Subregion are emphasized here.

\section{Geology and Landforms}

The topography of the Mixedgrass Subregion is generally subdued with only a few minor uplands. The predominant landforms are ground moraine and hummocky moraine but there are important areas of glaciolacustrine sand plains, and fine-textured glaciolacustrine lake deposits.

The few permanent streams are well defined. Drainage is either to the Missouri River system via the Milk River or to the Saskatchewan River system.

\section{Climate}

The climate of the Mixedgrass Subregion is slightly moister and cooler than that of the Dry Mixedgrass Subregion. The mean annual temperature is about $5^{\circ} \mathrm{C}$ with a mean summer temperature about $15^{\circ} \mathrm{C}$ that is $1-2^{\circ} \mathrm{C}$ cooler than the Dry Mixedgrass Subregion. Winter temperatures in the Mixedgrass Subregion are $1-2^{\circ} \mathrm{C}$ warmer than the Dry Mixedgrass Subregion, with a greater frequency of chinook days (20-30 days) but with greater snow cover 
due to greater winter precipitation. Annual precipitation in the Mixedgrass Subregion is about $20 \%$ greater than for the Dry Mixedgrass Subregion.

\section{Soils}

The characteristic soils of the Mixedgrass Subregion are Dark Brown Chernozems as contrasted with the Brown Chernozems of the Dry Mixedgrass Subregion. A few Black Chernozems occur on moister sites along the northern and western boundaries of this Subregion.

\section{Vegetation}

The vegetation of the Mixedgrass Subregion is similar to the Dry Mixedgrass Subregion. However, it is characterized by greater biomass production and a greater abundance of species that favour cooler and moister sites. Species such as Stipa curtiseta (western porcupine grass) and Agropyron dasystachyum (northern wheat grass) are more predominant than in the Dry Mixedgrass Subregion.

The majority of Mixedgrass vegetation is dominated by Stipa comata (spear grass), Stipa curtiseta (western porcupine grass), Agropyron smithii (western wheat grass) and A. dasystachyum (northern wheat grass). A Stipa curtiseta - Agropyron dasystachyum (western wheat grass - northern wheatgrass) community occurs widely in mesic sites. Fine-textured soils in glacial lake basins are characterized by the Agropyron dasystachyum - Koeleria macrantha (northern wheat grass - June grass) community. On drier, exposed sites Bouteloua gracilis (blue grama) is more common.

Typical vegetation of sandy areas includes Stipa comata (spear grass), Calamovilfa longifolia (sand grass), Koeleria macrantha (June grass) and a variety of low shrubs including Elaeagnus commutata (silverberry), Symphoricarpos occidentalis (western snowberry) and Rosa acicularis (prickly rose).

Extensive Populus angustifolia (narrow-leaved cottonwood) woodlands occur on fluvial terraces of the Oldman, Belly, Waterton, and St. Mary rivers and nowhere else in Canada.

Most of the natural vegetation of the Mixedgrass Subregion has been replaced by agricultural crops. The moister, cooler conditions of this Subregion, compared to the Dry Mixedgrass Subregion, are reflected in the greater productivity of rangelands that typically produce $25 \%$ more biomass.

\section{Wildlife}

The wildlife of the Mixedgrass Subregion is generally similar to but less diverse than that of the Dry Mixedgrass Subregion. Sandy areas are less common in this Subregion and extensive agricultural development has left comparatively little in natural habitat. 
The prairie biome and Alberta's Grassland Natural Region have changed dramatically over the past 100 years. The next chapter begins to explore briefly some changes that have occurred since settlement of the prairies in both Canada and the United States. 


\section{Chapter 1.3 The Historical Perspective}

Before settlement, the most significant impacts on the grassland landscape were wildfires, grazing and trampling by animals such as bison, and aboriginal activities such as hunting. The aboriginal peoples such as the Crow, Blackfoot and Sioux also deliberately burned extensive portions of the land regularly to "improve" the grasslands for bison and other ungulates (Edwards 1970, p114; Finlay 1996, p11). Natural disturbances such as fires, floods and grazing were a normal part of the prairie ecosystem and human impact on the prairie landscape and its species may have been relatively small, although Geist (1996, p62) proposes that aboriginal peoples in North America kept numbers of some species reduced.

The prairies were home to large herds of bison, Pronghorn and elk. That there were large numbers of bison ( 30 to 50 million) is well known, but other grazers were also numerous. One estimate, for example, listed "no fewer than 30 to 40 million Pronghorn on the continent prior to active European settlement" (Mitchell 1980, p7). Large predators such as wolves and grizzlies were common, as were species such as the Swift Fox, American Badger, Black-tailed Prairies Dog and Trumpeter Swan.

With the advent of the furtraders during the late 1700s and early 1800 s, furbearers, large mammals and some birds (e.g., Trumpeter Swans) were heavily trapped and hunted (Finlay 1996, p11). One trading post in Alberta in the spring of 1798 reported that a party of plains Indians had "traded 3212 Swift Foxes, 940 wolves, 22 Red Foxes, 13 Badgers, 6 Wolverines and 4 Grizzly Bears" (ibid,p13). Four years later, in the spring of 1802, there were 11,380 Swift Fox pelts shipped from another trading post in southern Alberta. In 1812, the Hudson's Bay Company in Edmonton traded for 1296 swan skins and 450 hundred weight of swan quills (ibid.). Many of these birds came from prairie habitats.

By the 1870s and 1880s, the bison had been hunted nearly to extinction, and numbers of elk and Pronghorn had declined on the prairies (Coupland 1973). Near the turn of the century, Pronghorn numbers had dropped dramatically due to "increased fencing of prairie lands, agricultural development, improper stock grazing practices, drought, market-hunting, and illegal year-round hunting" (Mitchell 1980). The once common Plains Grizzly was all but gone from southern Alberta by the $1880 \mathrm{~s}$, mainly due to over-hunting. It was the first large carnivore extirpated from the prairies. Three other carnivores - the Gray Wolf, Black-footed Ferret and Swift Fox - were also extirpated a few years later (Willms and Dormaar 1996, p35). By the early 1900 s, hunting had essentially "wiped out most of the accessible game to feed growing towns, mining camps, logging camps and other outposts. Elk survived only in a few small herds" (Van Tighem 1996, p6).

In the latter part of the 19th century, many prospectors, trappers, railroad builders, ranchers, settlers and adventurers were attracted to the prairies (PrairiNet Webmaster 1996). Ranchers became established and livestock was brought in. Until the introduction of livestock, bison had been the most significant herbivore on the grasslands. The effect that bison had on the development of prairie plant communities is not fully understood; but evidently "the grasses 
were adapted to the grazing imposed by bison" (Adams et al. 1993, p126). Whereas bison were migratory and their use of areas somewhat irregular, cattle and sheep are comparatively sedentary and their effects more localized. The introduction of domestic livestock altered the prairie to "a grazing regime dictated by property ownership, fences, and the management skills of the individual rancher or farmer" (ibid.). The late 1800 s were characterized by unrestricted yearround grazing, a situation that led to "substantial deterioration of many range areas" (ibid., p126, $131)$.

Around the turn of the century, another group of people came to the Great Plains - the homesteaders. These new settlers, called "sodbusters" by some, attempted intensive farming to raise cultivated crops rather than livestock. The cattlemen and sodbusters fought many local "range wars' over control of the land, particularly in the United States (PrairiNet Webmaster 1996).

Significant cultivation of the prairies began around the turn of the 20th century. In 1881, only 113,000 hectares were cultivated; by 1921 , there were 16 million cultivated hectares (IISD 1994, p21). Between 1881 and 1901, the number of farms on the prairies in Canada grew from 10,000 to over 55,000 (IISD 1994, p21). During the first 20 years of the 1900s, an additional 200,000 new farmers settled on the prairies. As settlement spread, farmers brought increasingly more land into cultivation. Governments encouraged this through "policy that classified uncropped land as unimproved" (Van Tighem 1996, p7).

Many homesteaders had little experience in agriculture or they had farmed where the climate was better. They expected to make a living on the same size farm, using the same farming practices as they had in the East or in Europe. Rainfall was only half what they were used to, and accordingly, production much lower. Planting crops every year gave the soil no chance to replenish its nutrients. Much of the dry land cultivated could not sustain crops in the long term (PrairiNet Webmaster 1996).

In the early 1900s, precipitation was above average and the newly-broken ground provided good crops. But in the early $1920 \mathrm{~s}$, rainfall decreased drastically and crops failed. As soil moisture continued to decrease, newly planted crops did not sprout, and the bare soil was exposed to severe wind erosion. With little vegetation to hold it in place, the soil began to move. "Thus began the 'dust bowl' with its black blizzards that plagued the Great Plains for nearly a decade" (PrairiNet Webmaster 1996). The Palliser Triangle, which encompasses much of the prairies in Alberta and Saskatchewan, would become infamous during the 1930s as the centre of the "dust bowl."

The financial crisis created by the Great Depression, when coupled with the intense drought, made the situation on the Great Plains even worse. By the early 1930s, hundreds of homesteaders were forced to leave their farms. The disaster throughout the Plains received international attention. Submarginal farms and depleted rangelands were purchased or reverted to the Crown, and the destitute were resettled. Slowly over the years, some of the prairie has been restored (PrairiNet Webmaster 1996). 
Our modern age has imposed "unprecedented stresses on the prairies, at times damaging and irreversible" (Adams et al. 1993, p131). Since settlement, natural fires have been suppressed and flood regimes have been altered. Natural grazing patterns by free-roaming native ungulates have been affected. Within only a few decades, human settlement and the degradation or loss of natural disturbance regimes have had significant impacts on prairie species, populations and ecosystems (Ostlie et al. 1996). Significant amounts of natural prairie have been lost in Canada and Alberta. The extent of grasslands remaining is explored in the next chapter. 


\section{Chapter 1.4 Grassland Remaining}

Coupland (1973) estimated that originally there were between 90 and 100 million acres (36 to 41 million hectares) of "open" grassland in Canada east of the Rockies. He notes that estimates of the extent of the original grasslands will vary, depending on how much of the forest/grassland ecotone is included. Weins (1996), for example, estimated the original extent of prairie in Canada at 50.1 million hectares. According to Samson and Knopf (1994), there were about 29.2 million hectares of prairie historically in the three western provinces. This estimate is significantly lower than that of Coupland or Weins, in part because it does not include Ontario prairie.

The Canadian prairie is among the most intensively developed landscapes in the world (Coupland 1973). If only arable prairie is considered, IISD (1994, p67) suggests that $81 \%$ (38 million hectares) has been cultivated. Most authors agree that, overall, at least $70 \%$ of the native prairie has been lost through cultivation, roads, urbanization and other factors, as suggested by the following estimates:

- $65-70 \%$ decline (Coupland 1973)

- 75\% decline (Weins 1996)

- 77\% decline (Samson and Knopf 1994)

- $87 \%$ decline (Diamond 1993, p180)

The amount of habitat loss in the grasslands increases in extent from west to east and is not distributed evenly among the three major grassland types, as illustrated in Table 3 and Figure 1.

Table 3. Estimated current area, historic area and percent decline of the prairies (after Samson and Knopf 1994)

\begin{tabular}{|l|l|r|r|c|}
\hline Prairie type & \multicolumn{1}{|c|}{ Province } & Historic area (ha) & Current area (ha) & Decline (\%) \\
\hline \multirow{2}{*}{ Tallgrass } & Manitoba & 600,000 & 300 & 99.9 \\
\hline \multirow{3}{*}{ Mixedgrass } & Manitoba & 600,000 & 300 & 99.9 \\
\cline { 2 - 5 } & Saskatchewan & $13,400,000$ & $2,500,000$ & 81.3 \\
\cline { 2 - 5 } & Alberta* & $8,700,000$ & $3,400,000$ & 61.0 \\
\cline { 2 - 5 } & SUM: mixedgrass & $22,700,000$ & $5,900,300$ & MEAN: mixedgrass $=74$ \\
\hline \multirow{2}{*}{ Shortgrass } & Saskatchewan & $5,900,000$ & 840,000 & 85.8 \\
\hline \multicolumn{2}{|l}{ *In Alberta, most of the native prairie remaining is in the Dry Mixedgrass Subregion. } \\
\hline
\end{tabular}




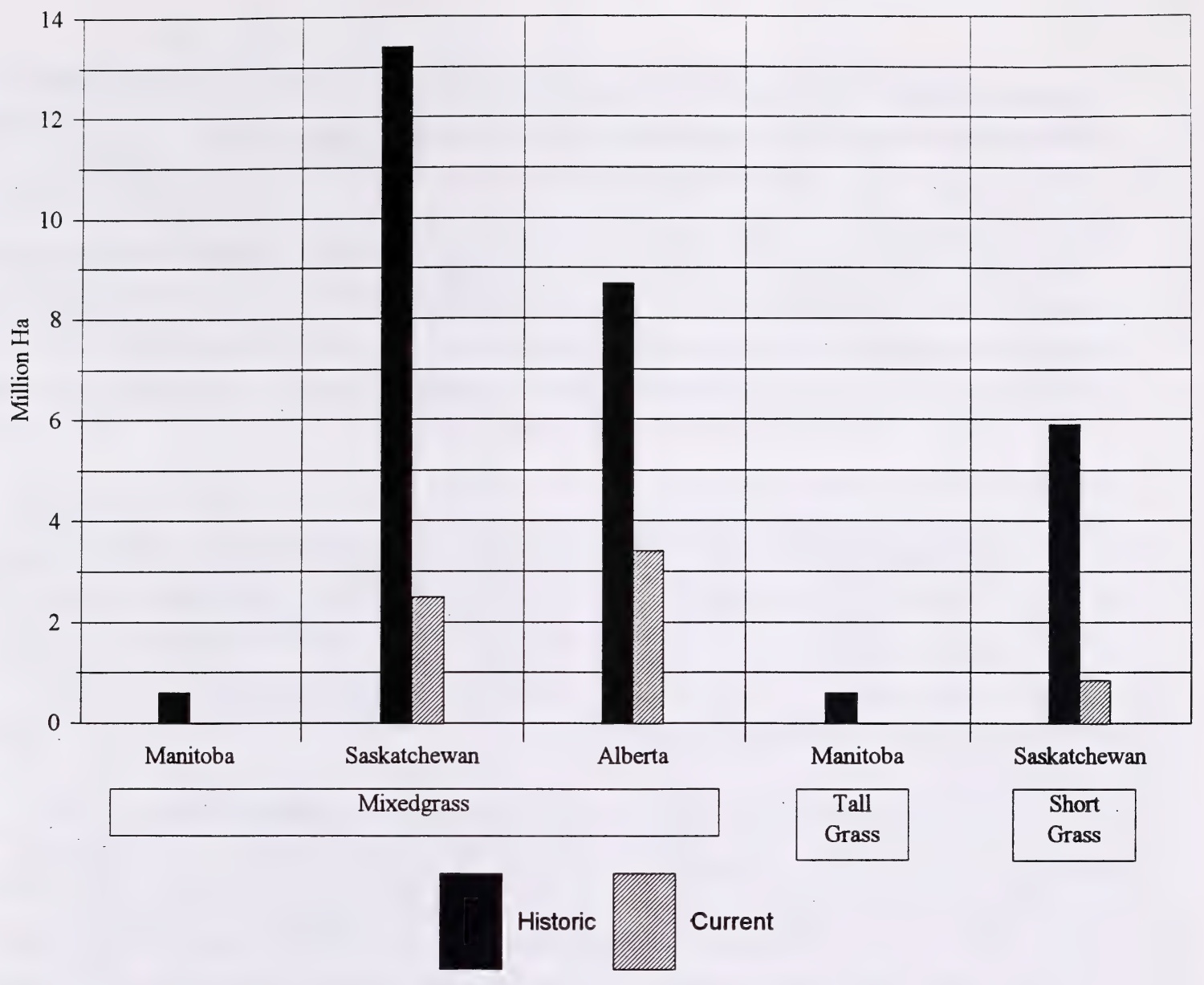

Figure 1. Decline of the Canadian Prairies (after Samson and Knopf 1994).

Tallgrass prairie has almost been eliminated from Canada, with only small remnants left in Manitoba and southern Ontario. In less than 130 years, tallgrass prairie region has changed from large expanses of native prairie into a highly fragmented landscape with little natural prairie remaining. Some estimate that less than $1 \%$ remains in Canada and less than $4 \%$ in North America (Ostlie et al. 1996, p50, Samson and Knopf 1994). The rest "has been converted to crop land, urban development, industrial sites, or has been invaded by forest cover" (Trottier 1992, p7). The amount of tallgrass prairie lost "exceeds that for any other major ecosystem in North America" (Ostlie et al. 1996).

Coupland (1973) considers the grasslands on the dark brown and brown soils in Alberta, Saskatchewan and extreme southwest Manitoba as mixed prairie. They make up "part of the most extensive grassland region that occupies the Great Plains southward to northern Texas." Coupland's "mixed prairie" corresponds well with the Dry Mixedgrass and Mixedgrass Natural Subregions of the Alberta Natural Regions classification (Land Information Services 1994). 
Most of the natural grassland remaining in Canada is mixedgrass prairie (Table 3). Trottier (1992, p13) proposes that it "comprises over half of the remaining native grassland." According to Samson and Knopf (1994), an estimated 22.7 million hectares of mixed prairie originally occurred in Manitoba, Saskatchewan and Alberta, as shown in Table 3. Coupland (1973) and Trottier (1992) estimated there were 24 million hectares of mixed prairie originally in Canada. Now, only about 5.7 to 5.9 million hectares of mixed prairie remain, a decrease ranging between $74 \%$ and $76 \%$ of the original amount (Baydack et al. 1995; Coupland 1973; Diamond 1993; Samson and Knopf 1994; Trottier 1992; Weins 1996). Within the North American Great Plains, estimates of the loss of mixed prairie range between $30 \%$ in Texas and $99.9 \%$ in Manitoba (Ostlie et al. 1996, p50). In Alberta, the amount of mixedgrass prairie, according to Samson and Knopf (1994), has declined by $61 \%$ from the original (Table 3 ).

Coupland (1973) considers the grasslands found on the black chernozemic soils of Alberta and western Saskatchewan as fescue prairie. In the United States, this type of grassland is found only in the Montana foothills (ibid.). Coupland's fescue prairie is roughly analogous in Alberta to the Northern and Foothills Fescue Natural Subregions; it also includes the Central Parkland Subregion of the Alberta Natural Regions classification (Land Information Services 1994). Fescue prairie in Alberta forms part of the Great Plains Steppe ecological province of Ostlie $e t$ al. (1996, p24). Some authors (e.g., Samson and Knopf 1994) include fescue prairie with mixedgrass prairie, in part due to its limited extent.

Fescue prairie originally covered over 25.5 million hectares in the prairie provinces (Trottier 1992). By 1973, only two to four million hectares (five to 10 million acres) of natural fescue grassland remained (Coupland 1973). The amount remaining is generally quoted at $5 \%$ (Weins 1996) or less of the original area (Alberta Prairie Conservation Forum 1995, Diamond 1993, Trottier 1992). Wallis (1987) concluded that fescue grasslands should be considered among the most threatened biogeographic regions on the Canadian plains because of extensive cultivation. He further suggested that any remaining areas should be considered endangered.

In Alberta, it is estimated that "more than $80 \%$ of the native prairie landscape has been transformed by agriculture, industry and urbanization" (The Alberta Prairie Conservation Forum 1995). The area of uncultivated grassland continues to decline (Coupland 1973).

The Department of Agriculture, Food and Rural Development (AFRD 1992) and ERCB (1992) evaluated the proportion of native prairie remaining in parts of southern Alberta. Table 4 presents some GIS-generated data from that evaluation. These data are presented in more detail for each of the grassland subregions in Chapters 2.4 to 2.7 in Part 2 of this report. The AFRD data was based on a quarter section level; the ERCB data was based on a township level.

The data show that a significant proportion $\left(53325 \mathrm{~km}^{2}\right.$ or about $56 \%$ ) of the Grassland Natural Region has $50 \%$ or less of its native prairie remaining (Table 4). Some of the most severe losses in native prairie have occurred in the Foothills Fescue and Mixedgrass Subregions. In the Mixedgrass Subregion, for example, about $13023 \mathrm{~km}^{2}(68 \%)$, is $50 \%$ or less native prairie. Of that, about $7700 \mathrm{~km}^{2}$ has no remaining native prairie (Figure 2). In the Foothills Fescue Subregion, at least $72 \%$ of the area has $50 \%$ or less native prairie. In comparison, in the Dry 
Mixedgrass Subregion, about $47 \%$ of the area is in that category. That subregion also has the highest proportion of native prairie remaining, $33 \%$ in the 76 to $100 \%$ category. The Northern Fescue Subregion has the least, at only 3\% (Table 4 ). This figure is only a rough estimate since data are unavailable for a large proportion $(27 \%)$ of this subregion.

Some of the best blocks of land having more than $75 \%$ in native prairie occur in extreme southeast Alberta, the Milk River Ridge area and the Suffield area (AFRD 1992). Landsat images for southern Alberta show that these are some of the best blocks of contiguous native prairie in the western plains of North America (Figure 3). In fact, "in North America, only Texas and North Dakota retain a larger native prairie land base than Alberta" (Prairie Conservation Forum 1997).

\begin{tabular}{|c|c|c|c|c|c|c|c|c|c|c|}
\hline \multirow[t]{2}{*}{$\begin{array}{l}\text { Proportion of native } \\
\text { prairie remaining* }\end{array}$} & \multicolumn{2}{|c|}{ Dry Mixedgrass } & \multicolumn{2}{|c|}{$\begin{array}{l}\text { Foothills } \\
\text { Fescue }\end{array}$} & \multicolumn{2}{|c|}{ Mixedgrass } & \multicolumn{2}{|c|}{$\begin{array}{l}\text { Northern } \\
\text { Fescue }\end{array}$} & \multicolumn{2}{|c|}{ Total } \\
\hline & $\mathrm{km}^{2}$ & $\%$ & $\mathrm{~km}^{2}$ & $\%$ & $\mathrm{~km}^{2}$ & $\%$ & $\mathrm{~km}^{2}$ & $\%$ & $\mathrm{~km}^{2}$ & $\%$ \\
\hline $76-100 \%$ & 15526 & 33 & 2044 & 14 & 3792 & 20 & 497 & 3 & 21859 & 23 \\
\hline $51-75 \%$ & 6483 & 14 & 536 & 3 & 810 & 4 & 3294 & 22 & 11123 & 11 \\
\hline Sub-total & 22009 & 47 & 2580 & 17 & 4602 & 24 & 3791 & 25 & 32982 & 34 \\
\hline $26-50 \%$ & 6161 & 13 & 1094 & 7 & 936 & 5 & 4149 & 27 & 12340 & 13 \\
\hline $1-25 \%$ & 2394 & 5 & 1277 & 9 & 1912 & 10 & --- & --- & 5583 & 6 \\
\hline $0-25 \%$ & 1692 & 4 & 6296 & 42 & 2443 & 13 & 3271 & 21 & 13702 & 14 \\
\hline $0 \%$ & 11948 & 25 & 2020 & 14 & 7732 & 40 & --- & --- & 21700 & 23 \\
\hline Sub-total & 22195 & 47 & 10687 & 72 & 13023 & 68 & 7420 & 48 & 53325 & 56 \\
\hline Data unavailable & 2772 & 6 & 1621 & 11 & 1552 & 8 & 4173 & 27 & 10118 & 10 \\
\hline Total & 46976 & 100 & 14888 & 100 & 19177 & 100 & 15384 & 100 & 96425 & 100 \\
\hline \multicolumn{11}{|c|}{$\begin{array}{l}\text { * Township data categories are } 0-25 \%, 26-50 \%, 51-75 \% \text { and } 76-100 \% \text {. Quarter-section data categories are } 0 \%, 1- \\
25 \%, 26-50 \%, 51-75 \% \text { and } 76-100 \% \\
\text { NOTE: Due to the precision levels of the data, especially township data, figures are estimates only. Federal crown } \\
\text { lands are not included in these calculations. }\end{array}$} \\
\hline
\end{tabular}

Woodlands on agricultural land in Alberta have decreased by $82 \%$ over a period of 55 years, from 1.56 million hectares in 1931 to 0.29 million hectares in 1986 (Weins 1996). The area in the prairie grasslands occupied by woodland decreased by at least $63 \%$ between 1971 and 1986 (Environment Canada 1991 in Diamond 1993, p180). 


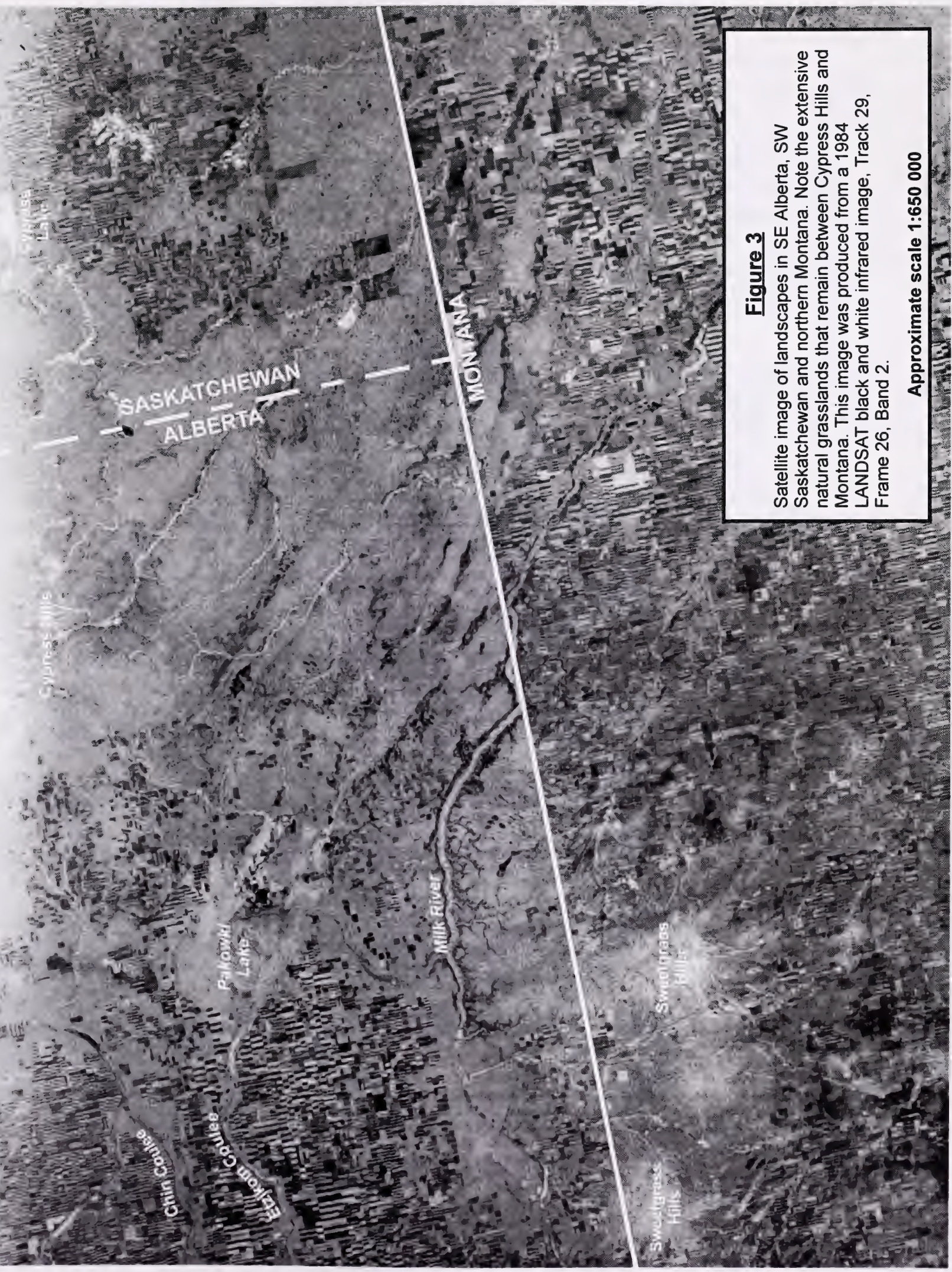




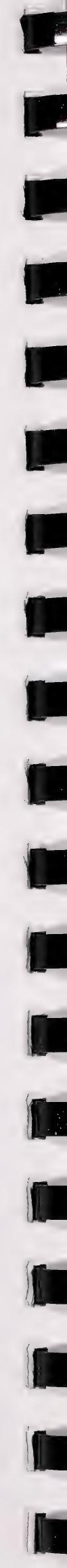


Historically, wetlands were often viewed as "wastelands", particularly in agricultural areas. There were more disincentives than incentives to preserve wetlands and wildlife habitat (IISD 1994, p71). As a result, wetlands were commonly drained and filled, and fields were cultivated from fence to fence. This practice "increased the total arable area and minimized the number of obstructions in fields" (Strong et al. 1993, p2). Since European settlement, wetland loss "has occurred throughout North America at an alarming rate and agriculture has been identified as the continuing major cause" (Usher and Scarth 1990, p5). In Canada, the modification of wetlands for agricultural purposes has accounted for $85 \%$ of total known changes (Cox 1993). In addition, transportation, utility, energy, and community developments, such as roads, pipelines, well-sites, or mines, have contributed directly or indirectly to the loss or degradation of wetlands (Alberta Water Resources Commission 1993a).

Extensive drainage of wetlands, including stream and river channelization, has occurred in many areas of the prairies. This practice began in the late $1800 \mathrm{~s}$ with settlement of the area and has been a major cause of wetland loss (Alberta Water Resources Commission 1993b). According to Usher and Scarth $(1990, \mathrm{p} 5)$,

" . . A first drainage peak was experienced at the beginning of the century as prairies were converted to crop and forage production. Drainage activity declined during the drought of the 1930s, but accelerated again in the late 1940s. In the mid1950 s, with the advent of larger farm equipment, wetland drainage expanded to include wetlands more difficult to drain. This trend has continued to the present and now includes drainage of wetlands on marginal agricultural land ..."

Alberta Environmental Protection (1996a) reported that in "the major irrigation districts [of southern Alberta] between 1977 and 1984, about 45\% of wetland losses were due to natural drying and succession; $30 \%$ to fall/winter grazing; $9 \%$ to cultivation; $6 \%$ to canal rehabilitation; $5 \%$ to drainage; and the remainder due to unknown causes."

According to Strong et al. (1993, p138), wetland losses are continuing even though "agricultural expansion in southern Alberta may be relatively static." For example, between 1973 and 1983, a $24 \%$ loss of critical wetland habitat occurred in six irrigation districts in southern Alberta (Alberta Forestry, Lands and Wildlife, n.d.). This was due, in part, to improved irrigation practices such as restoration of canals to improve water movement efficiency and conservation. Historically, leaky canals and ditch irrigation often resulted in wetlands being created along their margins. These canals and ditches were a source of water during midsummer when other wetland basins were dry.

Although all figures do not agree, clearly the extent of change to wetlands has been considerable, as documented by the following:

\section{Canadian Prairies:}

- Environment Canada (1986) as cited in Diamond (1993, p180) stated that "the number of prairie wetlands overall has declined by over $70 \%$ since European settlement."

- Over the last 200 years about 20 million hectares of Canadian wetlands have been converted to other uses. In Canada, almost $71 \%$ of wetland area has been lost (Westworth and 
Associates $1993 \mathrm{~b}, \mathrm{pl}$ ). In comparison, approximately $79 \%$ of freshwater wetlands have been lost in the U.S. (Wetlands for the Americas, n.d.).

- Environment Canada (1994) estimated that agricultural practices influenced about $22 \%$ of the wetland basins in prairie Canada in 1994.

- IISD $(1994, \mathrm{p} 71)$ estimated that $50 \%$ of the original prairie wetlands have been converted to agricultural land.

- PHJV $(1993, \mathrm{p} 5)$ proposed that $40 \%$ to $70 \%$ of the original wetlands have been lost in the prairies to various causes.

- Turner and Pryor (1992, p22) noted that for 1989 in prairie Canada, $75.2 \%$ of the wetland basins were degraded to some degree.

- IISD $(1994, \mathrm{p} 112)$ estimated that $40 \%$ of the original wetlands in the prairie region have been drained.

\section{Alberta Prairies}

- Strong et al. $(1993, \mathrm{p} 128)$ estimated that $63 \%$ of the original number of wetland basins that existed in the late 1800s in Alberta's White Area have been lost through agricultural and other landscape developments, at an annual attrition rate of about $1 \%$.

- O'Leary and Downing (1990) found that of the 55 townships within the Eastern Irrigation District [EID] of southern Alberta, 17 (31\%) had wetland habitat type losses greater than $30 \%$.

- Alberta Environmental Protection (1996a) proposed that, in the Grassland Natural Region, "there has been an estimated decrease in the number of wetlands of between $5 \%$ and $55 \%$ depending on the location."

- The Alberta Prairie Conservation Forum (1995) stated that 1.2 million hectares of prairie wetlands in Alberta have been converted to agricultural use.

- Schmitt (1980) estimated that Alberta's South Saskatchewan River basin alone suffered a $21 \%$ loss of wetland habitat between 1800 and 1979 .

"The continuing loss and degradation of wetland habitats in the prairie-parkland region of Canada are serious problems, particularly when viewed in the context that $40 \%$ of the wetlands have already been lost" (Canada/US Steering Committee 1996 as cited in Turner and Caswell 1989). Prairie wetlands are vulnerable to ongoing impacts due to the "climate of the area, the less permanent nature of wetlands, particularly during drought, and the various land use activities in the region" (Strong et al. 1993, p133). Turner and Caswell (1989), as cited in Strong et al. (1993, p129), listed some of the impacts and the extent to which they occurred on wetland basins. These were: burning (1.3\%), haying (4.9\%), grazing (22.4\%), and cultivation (34.9\%).

Despite the already extensive losses, draining and degradation of wetlands continues. The rates are variously estimated as follows:

- PHJV (1993, p5) found that during one five-year period (1981-1985), $60 \%$ of the remaining wetland basins were impacted.

- Strong et al. (1993, p127) reported that up to 2.4 wetland basins per square kilometer were lost between the 1970 and 1990 period due to human activity in Alberta's prairie area. 
- O'Leary and Downing (1990) found that the total wetland habitat in the EID of southern Alberta was reduced by 1234 hectares or by $7.6 \%$ between 1984 and 1987, an annual reduction of about $2.5 \%$.

- Brace and Pepper (1984) estimated that the drainage, filling and cultivation of wetlands in Alberta is occurring at a rate of about $13 \%$ per year.

Although the rate of wetland loss during the past few years may have slowed because of low grain prices, "drought conditions have allowed agricultural encroachment and greater margin impacts such as grazing" (Strong et al. 1993, p129). Bredy (1995, p4) noted that intensive farming practices such as the cultivation and burning of wetland margins was in progress throughout his survey area in May of 1995 in Alberta.

Wetland margins are consistently altered by various impacts at a "higher rate than wetland basins" (Usher and Scarth 1990, p6), as shown by the following:

- Turner and Pryor (1992, p22) noted that for 1989 in prairie Canada, $92.2 \%$ of the wetland margins were degraded to some degree.

- Nelson (1989) reported that $88 \%$ of wetland margins in prairie Canada had been impacted during the 1980 to 1987 period. He also estimated that of the 2.6 million wetlands in prairie Canada that held water in 1987, intact margins surrounded fewer than $400,000(15 \%)$.

- Environment Canada (1994) estimated that agricultural practices have affected about $80 \%$ of wetland margins in prairie Canada.

Turner and Caswell (1989), as cited in Strong et al. (1993, p129), listed some of the impacts and the extent to which they occurred on wetland margins. These were: burning $(0.9 \%)$, haying (4.7\%), grazing (33.2\%), and cultivation $(55.9 \%)$.

Cattle are attracted to wetlands and can contribute to their degradation. Grazing can eliminate food and cover plants, reduce nest-sites and overall habitat diversity. Cultivation of wetlands destroys the aquatic ecosystem and the plants, invertebrates and animals dependent on them (Ignatiuk and Duncan, 1995). The hardest hit wetlands are usually the shallow temporary ponds that are easily cultivated but are the preferred habitats for many species of ducks and other wildlife (ibid.).

The loss or degradation of wetlands through various agents destroys wildlife habitat and the staging and nesting areas for millions of migratory birds (Alberta Environmental Protection 1995; Alberta Water Resources Commission 1987, 1993a; Nietfeld et al. 1985). In addition, loss of wetlands results in reduced snow catchment and increased soil and water erosion (Ignatiuk and Duncan, 1995).

Drainage practices can be especially detrimental to nesting waterfowl (IISD 1994; Alberta Water Resources Commission 1987). This group of birds is "dependent not only on the wetland basins in an area but also on the quantity and quality of habitat surrounding the basins" (Turner and Pryor 1992, p113). From 1968 to 1991, there has been a general downward trend in the number of ponds present on the southern prairies during May (IISD 1994, p113). According to IISD, 
"the number of ponds occurring on the prairies in May is a factor of agricultural practices and weather patterns." May pond counts for 1992 were significantly lower than the long-term (i.e., 1961-1991) mean, partially due to the effects of El Nino (Turner and Pryor 1992, p18). "The coinciding population declines in May mallards indicates the relationship between May ponds and ducks" (ibid., p113). In 1985, the prairies experienced the lowest duck numbers in three decades, after years of drought and loss of habitat (NAWMP 1996).

Today, wetlands are more widely accepted as valuable ecosystems important in maintaining ecological diversity, wildlife habitat, hydrologic balance and water quality (Westworth and Associates 1993b; Alberta Water Resources Commission 1993a, 1993b). Helped by several seasons of high precipitation, NAWMP and other organizations and agencies are making progress in securing habitat and restoring waterfowl populations. Survey estimates in 1996 show that there has been an increase of about 35 million ducks since 1985. This is good news, but, the destruction of wetlands, although reduced, continues (ibid.).

The next chapter examines the issue of fragmentation, focusing on transportation networks and petroleum and natural gas activity. 


\section{Chapter 1.5 Fragmentation of Grasslands by Linear Disturbances}

\section{What is fragmentation?}

Fragmentation is a process with recognizable phases that occurs over time as developments slowly change the nature of a landscape. Initially, natural habitat is extensive and contiguous. It makes up the majority of the landscape, or forms the matrix. Natural habitat remains predominant in the early stages of fragmentation and the fragments remain mostly connected to each other. As the area becomes more developed, the landscape becomes dissected into smaller and smaller parcels. Eventually, the developed landscape forms the matrix, and only scattered fragments of the original natural habitat remain. The once-continuous expanse of prairie landscapes has been fragmented by roads, fences and hydroelectric lines, cultivation, towns and water reservoirs.

Most habitat fragmentation studies have looked at forest-dwelling birds. The studies generally conclude that there are "interior species," that rely on relatively large, undisturbed forest patches. Disturbances that cut through these patches introduce an "edge" into the once undisturbed area, bringing with it microclimatic changes, vegetational changes, species changes and increased predation and parasitism. Interior species tend to be "habitat specialists," the species that prefer edges are often "habitat generalists." As fragmentation proceeds, the patches become too small to support populations of interior species and edge species increase (Hobbs and Huenneka 1992). Recent studies have found that not only are birds affected by fragmentation, but also mammals (eg. Mills 1995; Stelfox 1995), invertebrates (eg. Webb 1988) and plants (eg. Jennersten 1988).

The interface between native prairie and tame pasture or hay fields is less dramatic than that between forest and clearing. This means that there is some question as to whether the effects of habitat fragmentation in prairies are comparable to those in forests. There are few studies that have looked at this question. Herkert (1994), in a three-year study of prairie fragments, found that fragment size "strongly influenced bird communities within grasslands." Larger fragments consistently had not only more breeding birds but also greater species richness. Some species were never found in smaller fragments, even when suitable habitat was present; some seemed more dependent on habitat type than fragment size, and some were clearly "edge" species (ibid.). Thus, as in forests, there are "area-sensitive" species in the prairies that require habitat of a minimum size. Burrowing owls, for example, are more likely to be found in larger pastures than on smaller ones (Ganes 1992). As fragmentation proceeds, these area-sensitive species would be predicted to be the ones showing the most serious population declines.

There is a point, termed a "critical threshold," at which the once-connected landscapes become disrupted. Once this point is reached, "small changes in the spatial patterning of resources can produce abrupt, sometimes dramatic ecological responses, with serious ecological consequences" (With and Crist 1995). Small changes in the composition of the landscape near the critical threshold are thus likely to have discernible effects on the distribution and persistence of 
populations. Persistance is a measure of whether a population dies out or maintains itself over the long term. The critical threshold is the "proportion of the landscape at which populations shift from random to clumped distributions" (ibid.). The switch occurs because the species no longer has an integrated landscape that it can move through, and populations concentrate in remaining suitable habitat.

The point that a critical threshold is reached for a species depends first on its degree of habitat specialization, that is, whether it can live in almost any type of habitat or if it is restricted to a single habitat type, like spiderworts are to open sand dunes. Based on computer simulation models done by With and Crist (1995), habitat specialists showed clumped distributions when $45 \%$ or less of the landscape was composed of their preferred habitat. Because they are so closely associated with a specific habitat, they were unlikely to leave once they encountered it (ibid.). When suitable habitat fell below $20 \%$ of the landscape, even species having low affinity to any particular habitat (habitat generalists), began to show clumped distribution. For habitat generalists, their ability to disperse seemed to have the greatest effect on the critical threshold, with small changes in dispersal ability greatly changing the critical threshold.

Whether a landscape has been fragmented beyond a critical threshold depends on the species being looked at, its degree of habitat specialization and its ability to move between habitat fragments. With and Crist (1995) summarize the threshold effect as follows, "Above this threshold, the primary effect of habitat fragmentation is loss of habitat with a concomitant decrease in species richness and population size. Below the threshold, habitat fragmentation increases isolation of habitat patches, thereby reducing landscape connectance."

Island biogeography theory has been used extensively to predict what happens when fragments have lost their connectedness. As summarized in Alberta Environmental Protection (1996), as fragments become isolated, the likelihood of individuals moving between fragments decreases, heightening the risk that species will become extirpated from the individual fragment. The effects on biodiversity can be devastating. Smaller patches can support fewer individuals, and smaller populations are more susceptible to local extinction than larger populations. "Habitat alienation and fragmentation can reduce the viability of plant and animal populations by reducing population levels, genetic diversity and gene flow among isolated subpopulations" (Westworth \& Associates 1993a, pN-2). Both Tilman et al. (1994) and Wickett et al. (1992, p115) have found that the rate of species extinctions increases as remnant size decreases and those species that survive have less chance of surviving over the long term. Habitat fragmentation has become recognized as the most serious threat to biological diversity, a "problem of global proportions" (Wickett et al. 1992, p115; Wilcox and Murphy 1985).

\section{Are the Alberta Prairies Fragmented?}

According to Wickett et al. (1992, p115), "the most severe case [of fragmentation] has occurred on prairies even though all ecosystems have been impacted." Once there were continuous expanses of native prairie, in various states of disturbance because of native ungulate grazing and natural fires. That situation has changed, as described by Owens and Myres (1973, p710): 
"...There [now] exists a patchwork made up of: (a) relatively undisturbed native prairies used as a source of wild hay, (b) grazed native prairie, (c) cultivated land with the native flora removed, (d) roadside ditches and field edges which often contain mixed exotic and native plant species, (e) land seeded to exotic grass species which may be used either as pastures or hay fields, and (f) areas where farm buildings and other structures have been erected often with windbreaks of native or introduced trees and shrubs..."

Native habitats now make up only "about $25 \%$ of the prairie landscape" (Bradley and Wallis 1996). Clearly, the answer is yes - the Alberta prairies have become a fragmented landscape.

\section{Agents of Fragmentation}

Many agents can cause fragmentation of habitats. Some of these include cultivation, urban developments, etc. Rivers can be fragmented by the presence of dams as discussed by Trant $e t$ al. (1995) and Van Tighem (1989). Two additional major agents of fragmentation in the prairies are transportation networks and petroleum and natural gas exploration and development (e.g., wellsites and access roads). These are addressed in the following discussion.

\subsection{Transportation Networks}

Noss (1995) states, "If I had to choose one indicator to assess and compare the ecological integrity of wildlands, it would be road density, as roads make most other human disturbances possible and have cumulative effects that persist as long as the roadbed is in place."

The use of land for transportation corridors (e.g., highways, roads, railroads) in Alberta has increased at a rapid pace since early settlement. Alberta now has over $50,000 \mathrm{~km}$ of roads and railroads in the Grassland Natural Region (Table 5), and over 95,000 km if wellsite roads are included (Table 6). Increased transportation networks increase "the ease of access to remote or inaccessible areas containing sensitive ecosystems" (Environment Canada 1986a). "Roads can change the flow of water through compaction, loss of infiltration, and alteration of surface flow resulting in the interruption of hydrological regimes" (Monds 1995). In addition, habitat is lost when a road is constructed and remaining habitat becomes further fragmented.

The Grassland Natural Region contains approximately 74,629 wellsites (Table 6), each reached by an access route with an estimated average road length of $0.6 \mathrm{~km}$ per well for the prairie area of Alberta Horejsi (1995). There are about 44,777 km of access roads (Table 6). Using an average width of 15 meters for wellsite roads (ibid.), they have replaced an estimated $672 \mathrm{~km}^{2}(=7.2$ townships) of habitat in the prairies. This is likely a maximum figure since some roads to abandoned wellsites may have been reclaimed. Reclaimed roads, however, are unlikely to have been seeded with native species. They are often seeded to non-native species such as crested wheatgrass. 
Road densities, expressed in $\mathrm{km} / \mathrm{km}^{2}$, have been used to predict "habitat effectiveness" (Horejsi 1995; Lyon 1983), particularly in forested environments. For example, the United States Forest Service [USFS] has determined that a maximum road density of $0.3 \mathrm{~km} / \mathrm{km}^{2}$ or lower is required to maintain the effective habitat for Grizzly Bears. At this density, habitat effectiveness is reduced to $80 \%$ of its potential (USFS 1990). For Elk, Lyon (1983) concluded that the habitat effectiveness would also be reduced to about $80 \%$ for multiple road systems with road densities in the order of $0.3 \mathrm{~km} / \mathrm{km}^{2}$.

Table 5. Linear distances $(\mathrm{km})$ of roads and railways in the Grassland Natural Region.

\begin{tabular}{|c|r|r|r|r|r|}
\hline Type of Road & Dry Mixedgrass & Foothills Fescue & Northern Fescue & Mixedgrass & Total \\
\hline Primary - paved & 1007.74 & 656.51 & 575.07 & 531.38 & 2770.69 \\
\hline Primary - divided & 217.22 & 205.17 & 0 & 170.96 & 593.36 \\
\hline Secondary - paved & 1111.64 & 777.62 & 567.63 & 691.80 & 3148.69 \\
\hline Secondary - gravel & 1190.91 & 289.55 & 442.08 & 294.81 & 2217.35 \\
\hline Improved & 9976.72 & 5277.42 & 4011.94 & 7242.30 & 26508.39 \\
\hline Unimproved & 2949.80 & 1704.82 & 1943.32 & 1226.18 & 7824.13 \\
\hline Truck trail & 2033.07 & 700.53 & 1484.82 & 464.05 & 4682.46 \\
\hline Railway* & 948.94 & 596.49 & 384.17 & 657.74 & 2587.34 \\
\hline "Highway" road length $\left(\mathrm{km}^{* * *}\right.$ & $19,436.06$ & $10,208.11$ & $9,409.02$ & $11,279.22$ & $50,332.41$ \\
\hline Area of Subregion $\left(\mathrm{km}^{2}\right)$ & $46,975.90$ & $14,888.27$ & $15,384.61$ & $19,176.65$ & $96,425.43$ \\
\hline Road density $\left(\mathrm{km} / \mathrm{km}^{2}\right)$ & 0.41 & 0.68 & 0.61 & & 0.58 \\
\hline * Railways were included in all calculations of road lengths and road densities. \\
\hline ** inghway" refers to all of the road types, including railways, listed in this table.
\end{tabular}

Studies in Wisconsin, Michigan, Ontario and Minnesota have shown a strong relationship between road density and the presence or absence of wolves. Wolves generally are not present where the density of roads exceeds $0.58 \mathrm{~km} / \mathrm{km}^{2}$ (Paquet and Hackman 1995, p12). In forested environments, Reed et al. (1996) proposed that the amount of land area that is "edge habitat" created by roads is 1.5-2.5 times the land area actually occupied by the roads. Although the literature varies regarding the amount of displacement and other impacts, there is irrefutable evidence that roads and associated disturbances "reduce habitat effectiveness resulting in reduced fitness and increased risk of mortality to species" (Paquet and Hackman 1995, p27). 


\begin{tabular}{|c|c|c|c|c|c|}
\hline Factor & Dry Mixedgrass & Foothills Fescue & Northern Fescue & Mixedgrass & Total \\
\hline Total no. wellsites & 51,931 & 2,335 & 13,207 & 7,156 & 74,629 \\
\hline Wellsite road length $(\mathrm{km})^{*}$ & $31,158.6$ & 1,401 & $7,924.2$ & $4,293.6$ & $44,777.4$ \\
\hline Area of Subregion $\left(\mathrm{km}^{2}\right)$ & $46,975.90$ & $14,888.27$ & $15,384.61$ & $19,176.65$ & $96,425.43$ \\
\hline Wellsite road density $\left(\mathrm{km} / \mathrm{km}^{2}\right)$ & 0.66 & 0.09 & 0.51 & 0.22 & 0.46 \\
\hline "Highway" road length $(\mathrm{km})^{* *}$ & $19,436.06$ & $10,208.11$ & $9,409.02$ & $11,279.22$ & $50,332.41$ \\
\hline $\begin{array}{l}\text { Total road length }(\mathrm{km}) \\
\text { (Wellsite + Highway) }\end{array}$ & $50,594.66$ & $11,609.11$ & $17,333.22$ & $15,572.82$ & $95,109.81$ \\
\hline $\begin{array}{l}\text { Overall road density }\left(\mathrm{km} / \mathrm{km}^{2}\right) \\
(\text { Wellsite + Highway) }\end{array}$ & 1.07 & 0.77 & 1.12 & 0.81 & 0.98 \\
\hline
\end{tabular}

When wellsite roads are considered, there is an overall road density of approximately $1 \mathrm{~km}$ of road for each square kilometer of land in the Grassland Natural Region (Table 6). Without wellsite roads, the road density drops to $0.52 \mathrm{~km} / \mathrm{km}^{2}$ (Table 5.. The Northern Fescue Subregion has the highest road densities $\left(1.12 \mathrm{~km} / \mathrm{km}^{2}\right)$ in the Grassland Natural Region when wellsite roads are included (Table 6, Figure 4). If wellsite roads are not included, then the Foothills Fescue Subregion has the highest at $0.68 \mathrm{~km} / \mathrm{km}^{2}$, (Table 5). When wellsite roads are included, the Foothills Fescue and Mixedgrass Subregion have the lowest road densities, at 0.77 and 0.81 $\mathrm{km} / \mathrm{km}^{2}$ respectively (Table 6). By comparison, in a study of linear disturbances in the Eastern Slopes, an overall road density of $0.40 \mathrm{~km} / \mathrm{km}^{2}$ was found (Alberta Environmental Protection 1996). This figure is similar for the road densities found in the Dry Mixedgrass Subregion (0.41 $\mathrm{km} / \mathrm{km}^{2}$ ), but is considerably lower than that found for the other three grassland subregions (Table 5). Although high, little work has been done on the effects of road densities on prairie ecosystems.

Roads and their rights-of-way occupy an area equivalent to 12.5 townships of land in the Grassland Natural Region and nearly 20 townships if wellsite roads are included (Table 7). This figure does not include the road networks in towns and cities. The Dry Mixedgrass Subregion, at $1.94 \%$, and Northern Fescue Subregion, at $2.1 \%$, have the highest proportions occupied by roads, if wellsite roads are included in the calculations (Table 7). If wellsite roads are not included, $1.65 \%$ of the Foothills Fescue Subregion has the highest proportion occupied by roads. This subregion has a significant level of major roads, including a stretch of Highway 2. 


\begin{tabular}{|c|c|c|c|c|c|c|}
\hline Type of Road & $\begin{array}{l}\text { Road + right- } \\
\text { of-way }(m)^{*}\end{array}$ & $\begin{array}{l}\text { Dry } \\
\text { Mixedgrass }\end{array}$ & $\begin{array}{l}\text { Foothills } \\
\text { Fescue }\end{array}$ & $\begin{array}{l}\text { Northern } \\
\text { Fescue }\end{array}$ & Mixedgrass & Total \\
\hline Primary - paved & 50 & 50.39 & 32.83 & 28.75 & 26.57 & 138.53 \\
\hline Primary - divided & 80 & 17.38 & 16.41 & 0 & 13.68 & 47.47 \\
\hline Secondary - paved & 30 & 33.35 & 23.33 & 17.03 & 20.75 & 94.46 \\
\hline Secondary - gravel & 30 & 35.72 & 8.69 & 13.26 & 8.84 & 66.52 \\
\hline Improved & 20 & 199.53 & 105.55 & 80.24 & 144.85 & 530.17 \\
\hline Unimproved & 20 & 59.00 & 34.10 & 38.87 & 24.52 & 156.48 \\
\hline Truck trail & 10 & 20.33 & 7.01 & 14.85 & 4.64 & 46.82 \\
\hline Railway & 30 & 28.47 & 17.89 & 11.52 & 19.73 & 77.62 \\
\hline Wellsite Roads & 15 & 467.38 & 21.02 & 118.86 & 64.4 & 671.66 \\
\hline \multicolumn{2}{|c|}{ Total (without wellsite roads) } & 444.17 & 245.81 & 204.52 & 263.58 & 1158.08 \\
\hline \multicolumn{2}{|c|}{ Total (with wellsite roads) } & 911.55 & 266.83 & 323.38 & 270.02 & 1829.74 \\
\hline \multicolumn{2}{|c|}{ Area of Subregion $\left(\mathrm{km}^{2}\right)$} & $46,975.90$ & $14,888.27$ & $15,384.61$ & $19,176.65$ & $96,425.43$ \\
\hline \multicolumn{2}{|c|}{ Area of Subregion (twp.) } & 503.86 & 159.69 & 165.01 & 205.69 & 1034.25 \\
\hline \multicolumn{2}{|c|}{$\begin{array}{l}\text { Percent of subregion occupied } \\
\text { by roads, excluding wellsite roads }\end{array}$} & 0.94 & 1.65 & 1.33 & 1.37 & 1.20 \\
\hline \multicolumn{2}{|c|}{$\begin{array}{l}\text { Percent of subregion occupied } \\
\text { by roads, including wellsite roads }\end{array}$} & 1.94 & 1.79 & 2.10 & 1.41 & 1.89 \\
\hline \multicolumn{2}{|c|}{$\begin{array}{l}\text { Land area (in townships) occupied } \\
\text { by roads, excluding wellsite roads }\end{array}$} & 4.76 & 2.63 & 2.19 & 2.82 & 12.42 \\
\hline \multicolumn{2}{|c|}{$\begin{array}{l}\text { Land area (in townships) occupied } \\
\text { by roads, including wellsite roads }\end{array}$} & 9.78 & 2.86 & 3.47 & 2.89 & 19.62 \\
\hline \multicolumn{2}{|c|}{$\begin{array}{l}\text { Land area (twp.) occupied by } 23 \mathrm{~m} \\
\text { zone on each side of all roads"* }\end{array}$} & 14.17 & 7.54 & 6.74 & 8.42 & 36.87 \\
\hline \multicolumn{2}{|c|}{$\begin{array}{l}\text { Total land area (twp.) occupied by } \\
\text { roads plus } 23 \mathrm{~m} \text { zone (including } \\
\text { wellsite roads) }\end{array}$} & 23.95 & 10.40 & 10.21 & 11.31 & 56.49 \\
\hline \multicolumn{2}{|c|}{$\begin{array}{l}\text { Percent of subregion occupied by } \\
\text { all roads plus the } 23 \mathrm{~m} \text { zone }\end{array}$} & 4.75 & 6.51 & 6.19 & 5.50 & 5.46 \\
\hline
\end{tabular}



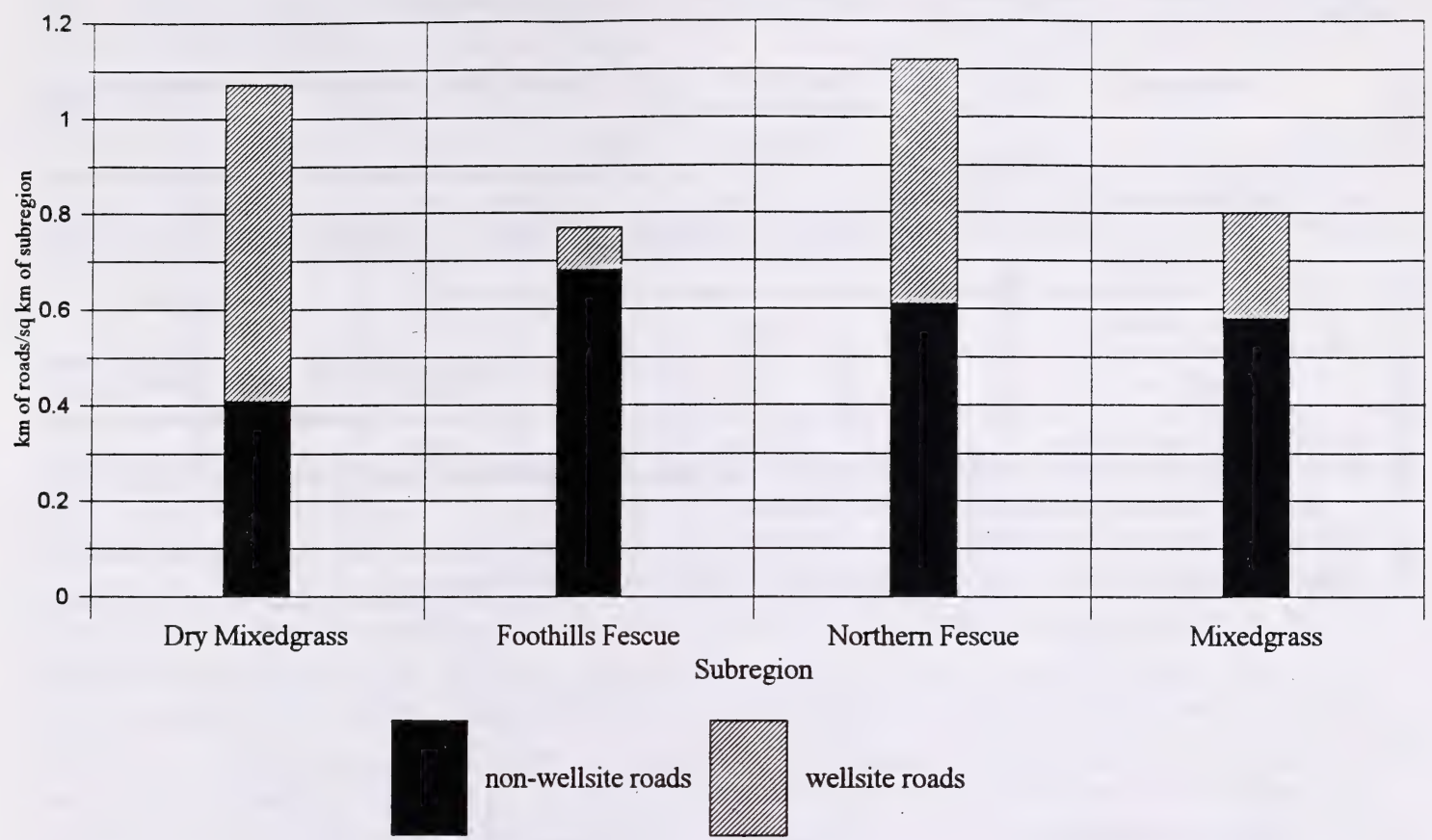

Figure 4. Road densities in Alberta's grassland subregions.

When development occurs, an edge is created. This has associated edge effects that influence the native habitat beyond the actual development itself. Edge effects have not been well studied in prairie ecosystems. One study, however, found "alien" or exotic plant species (Christiansen 1990, p127) in a $23 \mathrm{~m}$ wide zone on either side of the road right-of-way. If this is the case for the Alberta prairies, then an additional area equivalent to 37 townships (Table 7) would have reduced habitat quality due to edge effects alone.

If all roads plus the $23 \mathrm{~m}$ zone of influence on either side are considered, an area equivalent to 56 townships of land, or 5.4\%, of the Grassland Natural Region has been affected (Table 7). Of the four subregions, the highest proportion occupied by roads (including wellsite roads) and the associated $23 \mathrm{~m}$ zone of influence, at $6.51 \%$ and $6.19 \%$ respectively (Table 7 ), is in the Foothills Fescue and Northern Fescue Subregions.

Within the Grassland Natural Region, few extensive areas remain roadless (Map B, back of document). When road density classes and their distribution within the four grassland subregions are considered, more of the Dry Mixedgrass and Mixedgrass Subregions are in the lower road density classes $\left(<0.5 \mathrm{ha} / \mathrm{km}^{2}\right)$ than are the Foothills Fescue and Northern Fescue Subregions (Table 8, Figure 5). Approximately $5.7 \%$ of the Dry Mixedgrass Subregion has no roads. This figure, however, is misleading. Road information for Suffield Military Reserve was unavailable so the entire area was arbitrarily given a density of zero. This skewed the data 
Table 8. Proportion of the grassland subregions occupied by road density classes*.

\begin{tabular}{|c|c|r|r|r|r|r|}
\hline \multirow{2}{*}{ Subregion } & \multicolumn{6}{|c|}{ Road density classes $\left(\mathrm{ha} / \mathrm{km}^{2}\right)$ and their proportions in each subregion (\%) } \\
\cline { 2 - 7 } & 0 & $0.01-0.5$ & $0.51-1$ & $1.1-1.5$ & $1.51-2.5$ & $>2.51$ \\
\hline Dry Mixedgrass & $* * 5.7$ & 21.9 & 31.9 & 23.2 & 15.2 & 2.1 \\
\hline Foothills Fescue & 0.3 & 5.7 & 14.5 & 23.2 & 43.4 & 12.9 \\
\hline Northern Fescue & 0 & 6.4 & 25.9 & 33.1 & 31.7 & 2.9 \\
\hline Mixedgrass & 1.2 & 14.1 & 18.6 & 26.2 & 31.1 & 8.8 \\
\hline Grasslands Natural Region & 3.0 & 15.4 & 25.6 & 25.4 & 25.4 & 5.2 \\
\hline
\end{tabular}

* Wellsite roads are not included in these calculations.

** Road data not available for CFB Suffield. The entire area was given a density of zero, hence the apparently high percentage $(5.7 \%)$ of unroaded area within the Dry Mixedgrass Subregion.

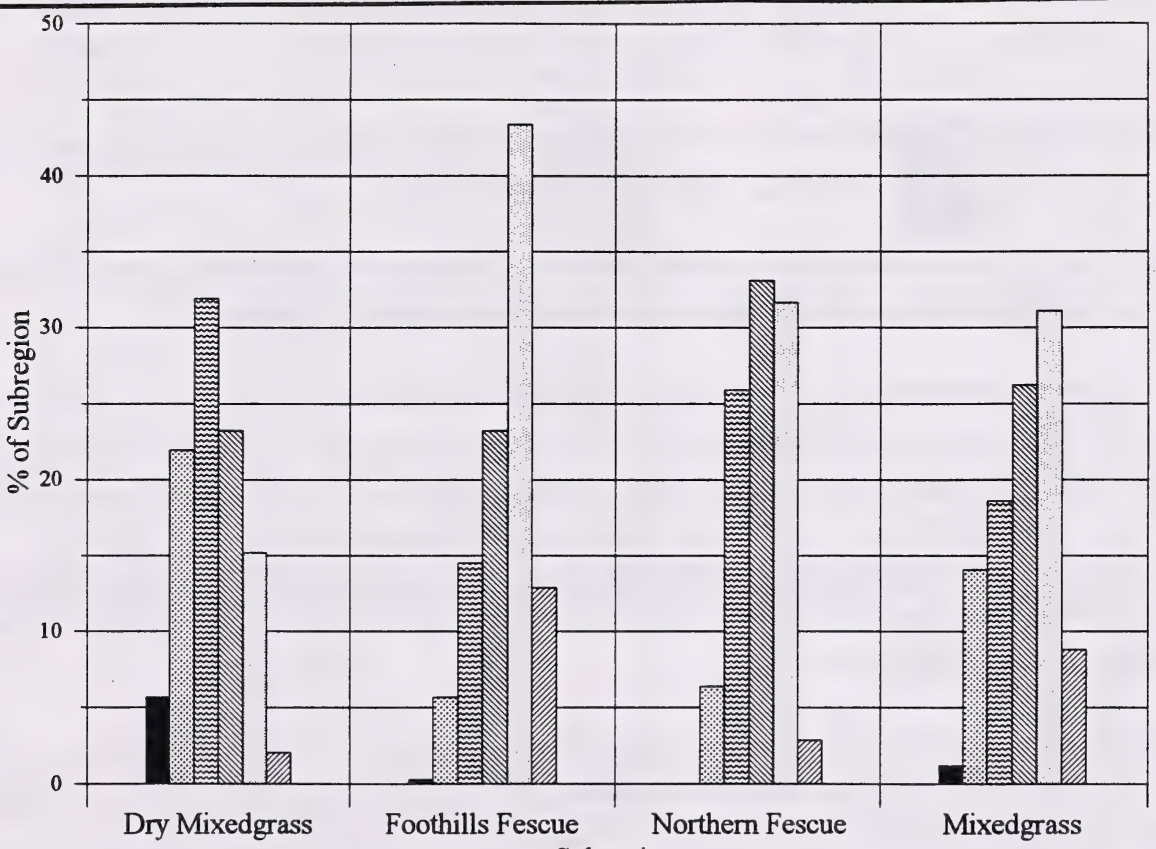

Subregion

$\mathrm{Ha} / \mathrm{Sq} . \mathrm{Km}$.
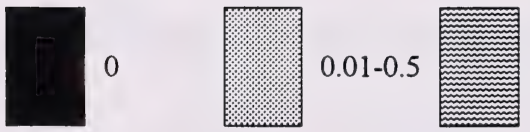

$0.51-1$

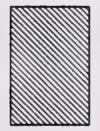

$1.1-1.5$

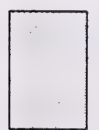

$1.51-2.5$

$>2.51$

Figure 5. Proportion of the grassland subregions occupied by road density classes 
resulting in the high percentage shown. A disproportionately large area of the Foothills Fescue Subregion is in the higher road density classes $\left(>1.5 \mathrm{ha} / \mathrm{km}^{2}\right)$, at approximately $56 \%$. Map 2 illustrates the distribution of road density classes in the Grassland Natural Region.

Townships with the highest road densities are more fragmented than those in the lower density classes. Natural habitat is lost and the potential for invasion by exotic species is increased. This reduces their ecological integrity and value for protected areas.

\subsection{Petroleum and Natural Gas Activities}

Of all the energy produced in Canada in 1995, about 70\% comes from Alberta (Alberta Energy and Utilities Board 1996). The province has just over $60 \%$ of the country's conventional oil reserves and $83 \%$ of the natural gas reserves. Development and production of reserves can take many years and involves the construction of wells, roads and facilities. "Once a field has been established, environmental disruptions become extensive, cumulative, often long term, and would occur continually in varying degrees because of the need for recurring human activity" (Bromley 1985). In a letter addressed to all oil, gas and pipeline operators in the province, the ERCB stressed the need for "an increased awareness by industry, government, and the public that native prairie grassland is a rapidly disappearing ecosystem, and that the cumulative long-term impact of all development, including oil and natural gas, can be very significant" (National Energy Board 1996, p31).

Some cumulative impacts include: soil compaction, stripping and mixing of soil, increased erosion, increased weed invasion, provision of access into once inaccessible areas, the construction of roads, wellsites, pipelines and production facilities, accidental spills (crude oil, drilling fluids, salt water, natural gas), hydrogen sulphide emissions and other pollutants, and the accumulation of debris and wastes from construction and drilling activities (ERCB 1992; National Energy Board 1996). Fuel spills are especially destructive. "The imprint on the land from many of these activities is usually permanent" (ERCB 1992, p1-2).

Wildlife and their habitats have been affected by activities associated with the petroleum industry. There is often considerable fragmentation and loss of native habitat. The severity is "site-specific and depends on the sensitivity of the species affected, the nature of the environmental disruption, habitat characteristics, the availability and condition of alternative habitat," and other factors (Bromley 1985). For example, Pronghorn and other animals tend to be temporarily or permanently displaced from areas of active drilling, pipeline construction and well maintenance (Bromley 1985; Easterly and Guenzel 1992; National Energy Board 1996). Flare stacks have been implicated in causing mortality to some bird species (Bjorge 1987) and toxic pits have caused wildlife deaths (e.g., coating of waterfowl with oil). Hunting pressure on wildlife populations may increase due to increased access (Bromley 1985). 
Since keeping of well records started in 1902, approximately 167,000 gas and oil wells have been drilled in Alberta (Alberta Energy and Utilities Board 1996).

According to Kerr et al. (1993), nearly 110,000 oil and gas well sites have been constructed. The 1996 digital files of the Alberta Energy and Utilities Board, however, show fewer wellsites, nearly 75,000 (about $45 \%$ of the total for Alberta) have been drilled within the Grassland Natural Region (Table 9). This equates to a wellsite density of 0.77 wellsites $/ \mathrm{km}^{2}$ or one wellsite/1.29 $\mathrm{km}^{2}$. Wellsite locations are plotted on Map B (back of document) and wellsite densities graphically depicted in Figure 6. If an average lease size is 1.4 hectares (Horejsi 1995), then with 74,629 wellsites, a cumulative land area of about $1045 \mathrm{~km}^{2}$ (=11.2 townships) has been directly affected by this activity.

Table 9. Wellsites in the Grassland Natural Region.

\begin{tabular}{|c|r|r|r|r|r|}
\hline Wellsites & \multicolumn{1}{|c|}{$\begin{array}{c}\text { Dry } \\
\text { Mixedgrass } \\
\text { Subregion }\end{array}$} & $\begin{array}{c}\text { Foothills } \\
\text { Fescue } \\
\text { Subregion }\end{array}$ & $\begin{array}{c}\text { Northern Fescue } \\
\text { Subregion }\end{array}$ & $\begin{array}{c}\text { Mixedgrass } \\
\text { Subregion }\end{array}$ & Total \\
\hline Total no. wellsites & 51,931 & 2,335 & 13,207 & 7,156 & 74,629 \\
\hline Area of Subregion $\left(\mathrm{km}^{2}\right)$ & $46,975.90$ & $14,888.27$ & $15,384.61$ & $19,176.65$ & $96,425.43$ \\
\hline wellsites/km ${ }^{2}$ & 1.11 & 0.16 & 0.86 & 0.37 & 0.77 \\
\hline $\mathrm{Km}^{2} /$ wellsite & 0.91 & 6.38 & 1.17 & 2.68 & 1.29 \\
\hline Mean no. wellsites/twp. & 103.02 & 14.62 & 80.03 & 34.79 & 72.16 \\
\hline
\end{tabular}

The Grassland Natural Region wholly or partially overlies at least 183 natural gas and 42 oil fields (Energy Resources Conservation Board, 1994). These fields cover approximately $75 \%$ of the natural region. For a given reservoir, the well densities normally permitted in Alberta are one per square mile $\left(2.59 \mathrm{~km}^{2}\right)$ for gas and 16 per square mile for oil (i.e., one per $\left.0.16 \mathrm{~km}^{2}\right)$. In exceptional circumstances oil well densities may be as high as four per legal subdivision (i.e., one per $0.04 \mathrm{~km}^{2}$ ). The difference in oil and gas well spacing has important implications for the intensity of environmental impacts from oil versus gas exploration, drilling and production. To process the production from these fields, there are at least 51 natural gas processing plants within this region with a capacity of over 0.5 million cubic metres per day (ibid.). 


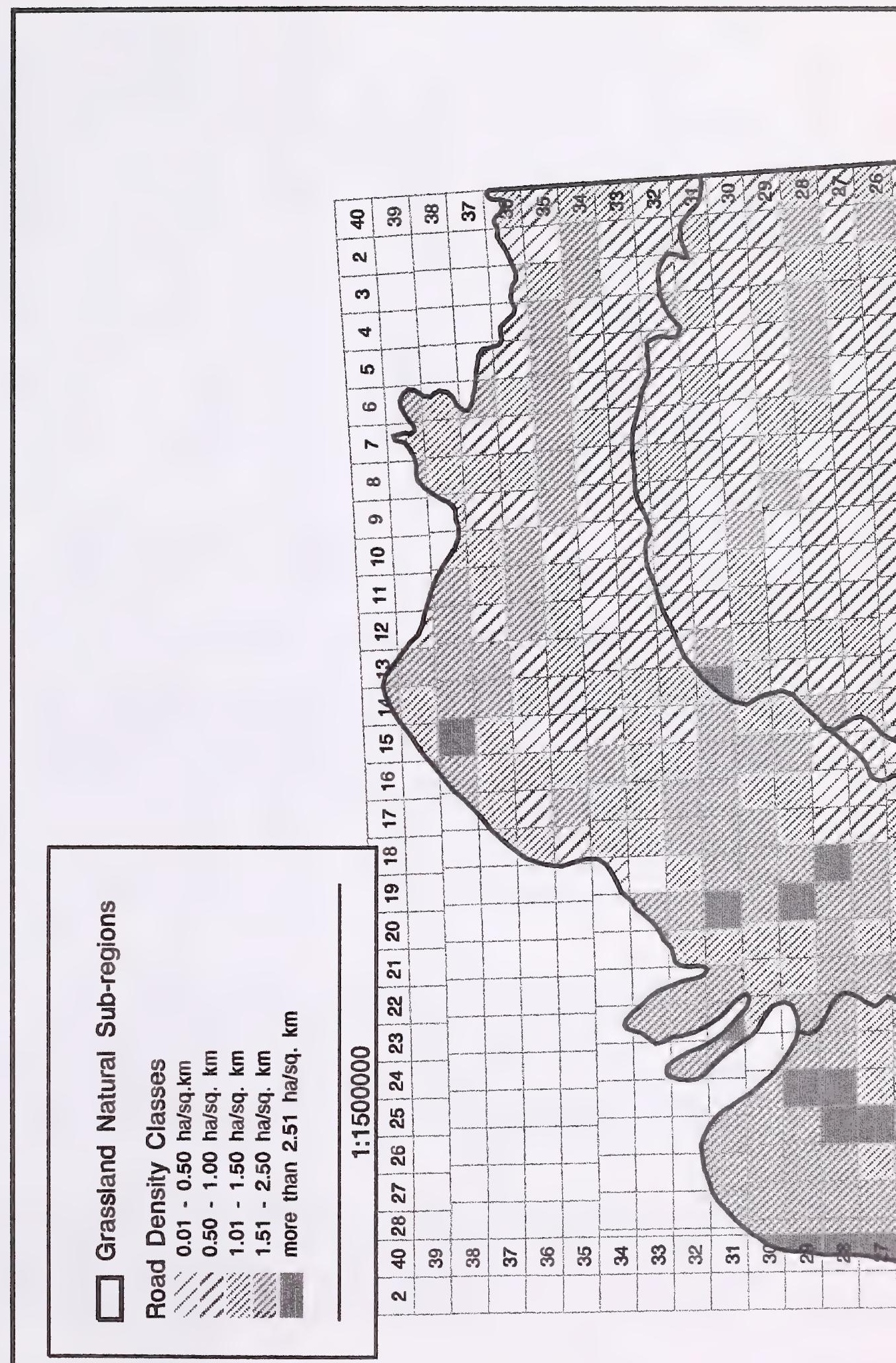




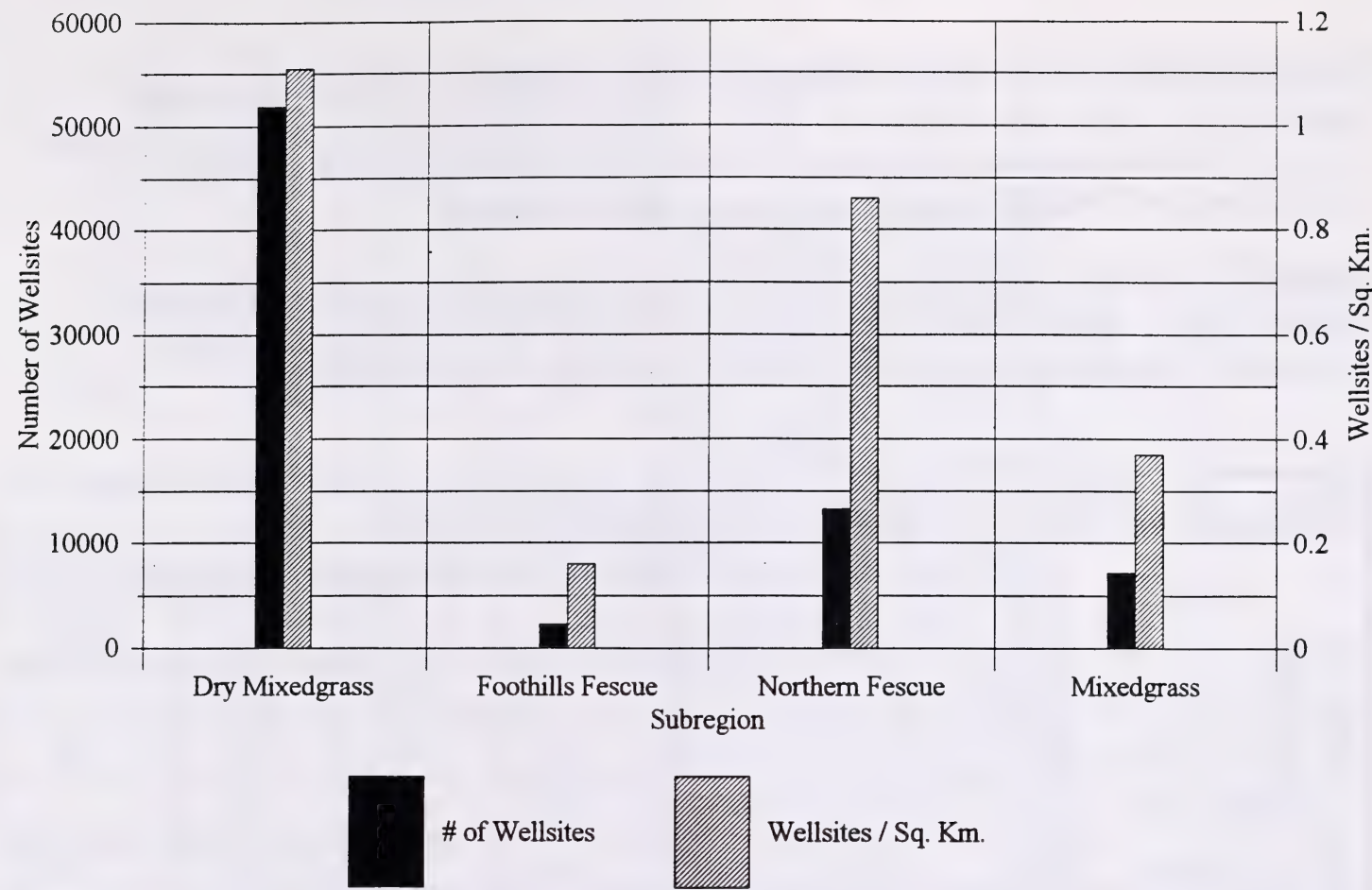

Wellsites / Sq. Km.

Figure 6. Wellsites and wellsite densities in Alberta's grassland subregions.

As Map 3 shows, wellsite concentrations are densest over major gas and oil fields in the central portion of the Dry Mixedgrass Subregion and the northeastern portion of the Northern Fescue Subregion. Major oil and gas fields located in these areas include Taber, Grand Forks (northeast of Taber), Suffield, Bantry (west of Suffield) and Provost. The highest well densities recorded for the Grassland Natural Region occur in T20-R8-W4M, in the area overlying the Suffield and Jenner gas/oil fields. In this township there have been at least 762 wells drilled. This amounts to a density of 8.17 wells $/ \mathrm{km}^{2}$ or one well per $0.12 \mathrm{~km}^{2}$. Of the four grassland subregions, the Dry Mixedgrass and Northern Fescue Subregions have been impacted the most by oil and gas exploration and development.

Wellsite densities for the Grassland Natural Region are high relative to the other natural regions. For example, the Foothills Natural Region has wellsite densities of 0.28 wellsites $/ \mathrm{km}^{2}$ or one wellsite $/ 3.52 \mathrm{~km}^{2}$ (Alberta Environmental Protection 1996, p17). This is about one-third the density of wellsites found in the Grassland Natural Region. The Lower Foothills Subregion has wellsite densities of 0.33 wells $/ \mathrm{km}^{2}$ [i.e., 1 well $/ 3.0 \mathrm{~km}^{2}$ ], the highest in the Foothills Natural Region (ibid.). This is less than one-third the densities found in the Dry Mixedgrass Subregion (Table 9).

Comparison of wellsite density data in the Dry Mixedgrass (38.8\%) and the Northern Fescue (23.9\%) Subregions shows that these two have the highest proportion occupied by wellsites densities (Table 10, Figure 7). The Dry Mixedgrass Subregion contains nearly 52,000 wellsites, about $70 \%$ of the total number of wellsites in the Grassland Natural Region. By comparison, 
only $0.8 \%$ of the Foothills Fescue Subregion, with 2335 wellsites, is occupied by wellsite densities greater than one wellsite $/ \mathrm{km}^{2}$. Also, $9.6 \%$ of that subregion is wellsite free, the highest of any of the four grassland subregions (Table 10). Only a small proportion of the Dry Mixedgrass and Northern Fescue Subregions are without wellsites.

Townships with the highest wellsite densities are more fragmented than those in the lower density classes. Natural habitat is lost and the potential for invasion by exotic species is increased. This reduces their ecological integrity and value for protected areas.

Table 10. Proportion of the grassland subregions occupied by wellsite density classes.

\begin{tabular}{|c|c|r|r|r|r|r|}
\hline \multirow{2}{*}{ Subregion } & \multicolumn{6}{|c|}{ Wellsite density classes (\# wellsites/(km ${ }^{2}$ ) and their proportions in each subregion (\%) } \\
\cline { 2 - 7 } & 0 & $0.01-0.5$ & $0.51-1$ & $1.1-2$ & $2.1-4$ & $4.1-8$ \\
\hline Dry Mixedgrass & 0.1 & 43.2 & 17.9 & 19.2 & 17.4 & 2.2 \\
\hline Foothills Fescue & 9.6 & 84.7 & 4.9 & 0.8 & 0 & 0 \\
\hline Northern Fescue & 0.1 & 40.2 & 35.8 & 17.2 & 5.4 & 1.3 \\
\hline Mixedgrass & 0.7 & 75.5 & 16.9 & 6.5 & 0.3 & 0.1 \\
\hline Grassland Natural Region & 1.7 & 55.5 & 18.6 & 13.5 & 9.4 & 1.3 \\
\hline
\end{tabular}

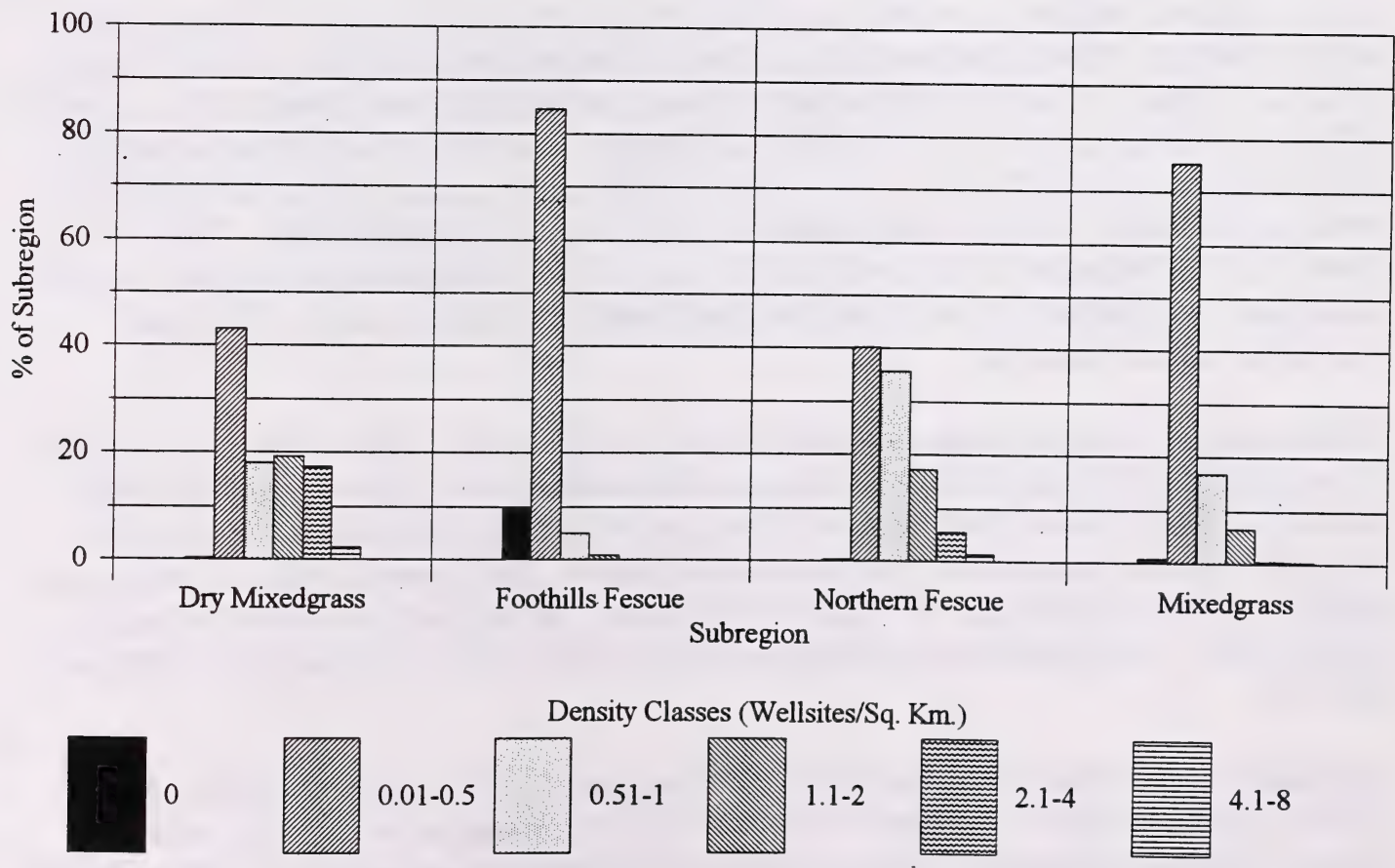

Figure 7. Proportion of the grassland subregions occupied by wellsite density classes. 

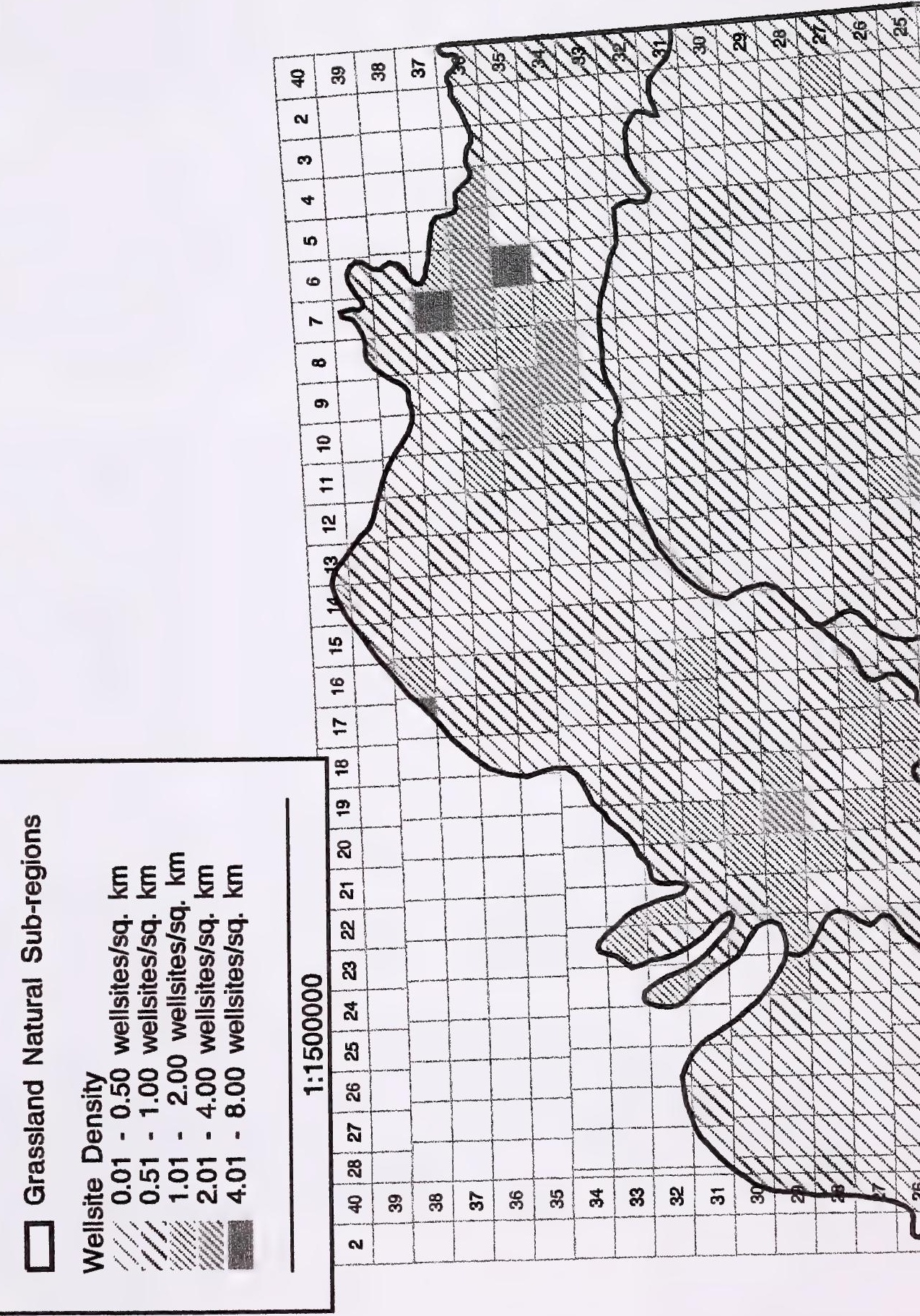
W.

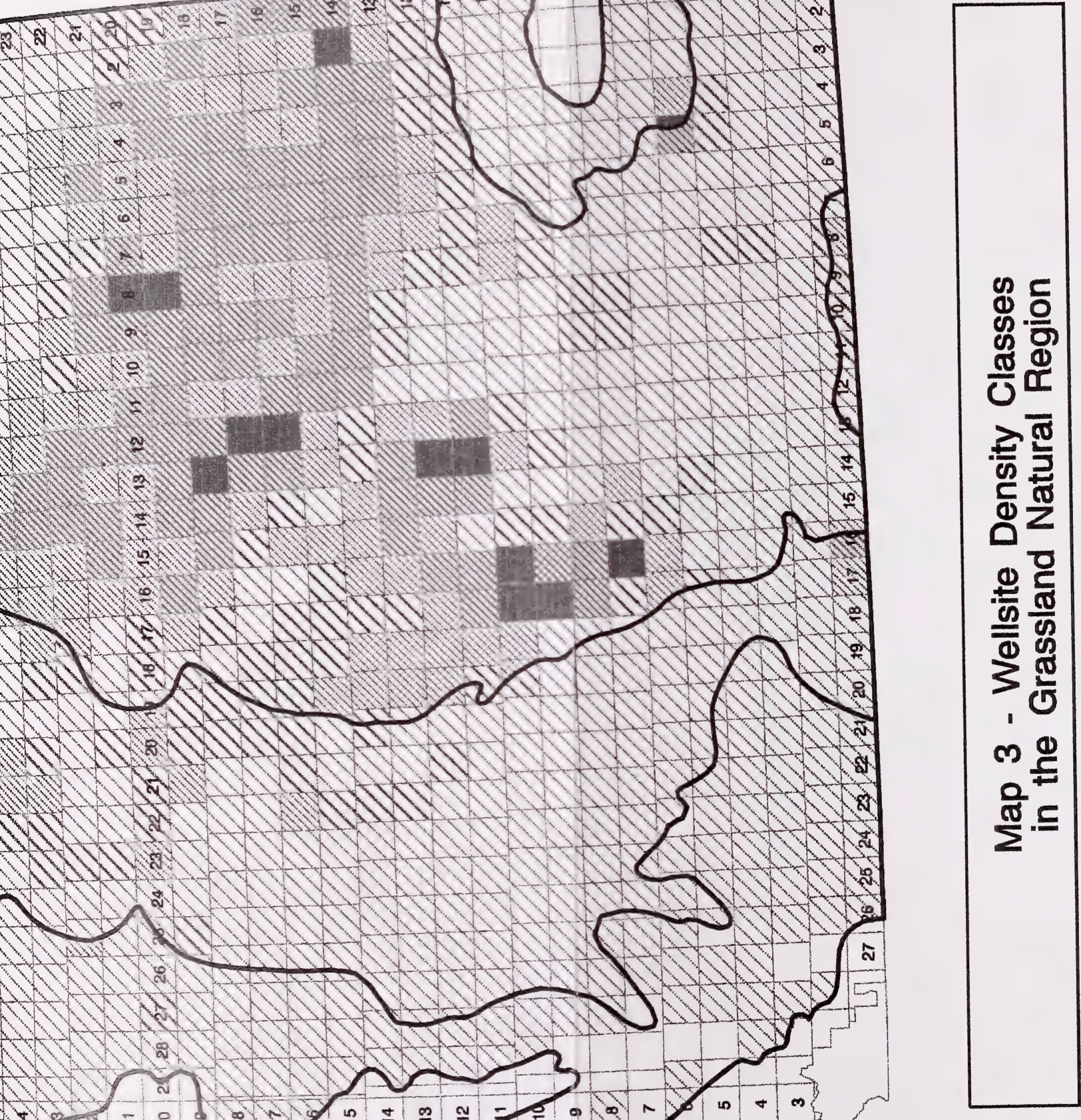


There are also pipelines and associated access routes throughout much of Alberta. During 1995, for example, construction permits were approved for $10,590 \mathrm{~km}$ of pipelines. This is down $25 \%$ from the record level of $14,300 \mathrm{~km}$ of pipeline constructed in 1994. The total length of pipelines in Alberta was 250,498 $\mathrm{km}$ at the end of 1995 (Alberta Energy and Utilities Board 1996). Using an average width of 15 meters for pipeline rights-of-way (Horejsi 1995), they have impacted an estimated $3757 \mathrm{~km}^{2}$ (40.3 townships) of land in the province. For the recently-constructed Express Pipeline from Hardisty to Wildhorse, it was estimated that 717 ha (nearly $3 \mathrm{mi}^{2}$ ) of uncultivated land would be disturbed (National Energy Board 1996, p31).

As discussed above, about $45 \%$ of the wellsites in Alberta are within the Grassland Natural Region. Assuming that about $45 \%$ of the pipeline activity has also occurred in that region, then pipelines there have directly affected about $1690 \mathrm{~km}^{2}$ (18.1 townships) in the grasslands. Map 4 demonstrates the impact pipeline development can have on an area. All nine sections in this area have been affected, with at least three being heavily affected. This area was chosen since it is one of 14 townships in the highest wellsite density class $\left(4.01-8\right.$ wellsites $\left./ \mathrm{km}^{2}\right)$ within the Grassland Natural Region (Map 3). In this area considerable habitat has beem lost and the landscape is clearly fragmented.

Construction of pipelines has influenced Alberta prairies in several ways. Total plant cover is generally less and species composition is different on pipeline rights-of-way than on adjacent undisturbed areas, especially in native prairies (Hardy and Associates Ltd. 1975). Also, plant cover can be very patchy, perhaps due to the mixing of surface and subsurface soils during the construction phase of the pipeline (ibid.). Pipeline rights-of-way typically support many weedy species (e.g., thistle, foxtail barley, knotweed) and often have been seeded with exotic species (e.g., crested wheat grass, smooth brome). Native grasses are generally poorly represented since invasion of native species onto the rights-of-way in native prairies appears to be a slow process. AWA and FAN stated in a submission by to the Express Pipeline Project Hearing that "after five years or even 25 or 50 years, there still may not be the mix of species which was present before construction" (National Energy Board 1996, p38).

In addition, "animal burrows are frequently concentrated in the berms" of the pipeline route (Hardy and Associates Ltd. 1975). Cattle frequently amplify the pipeline disturbance by concentrating trails, bedding and grazing on the rights-of-way. They often preferentially graze seeded rights-of-way over native pastures. According to the National Energy Board (1996, p49), "long-term sedimentation problems [in rivers] can also occur after pipeline construction where right-of-way preparation has removed stabilizing vegetative structures."

Many species used in the seed mixtures for reclamation of pipelines are invasive. Smooth brome, for example, is "an aggressive invader of prairie dominated by plains rough fescue" (Grilz and Romo 1995). As discussed earlier, non-native species have been shown to invade into the prairie up to $23 \mathrm{~m}$ from a disturbance edge (Christiansen 1990). If a $23 \mathrm{~m}$ zone of disturbance was added to both sides of the estimated $1690 \mathrm{~km}^{2}$ of pipeline rights-of-way, this would significantly increase the estimated land area impacted by pipelines in the grasslands. 


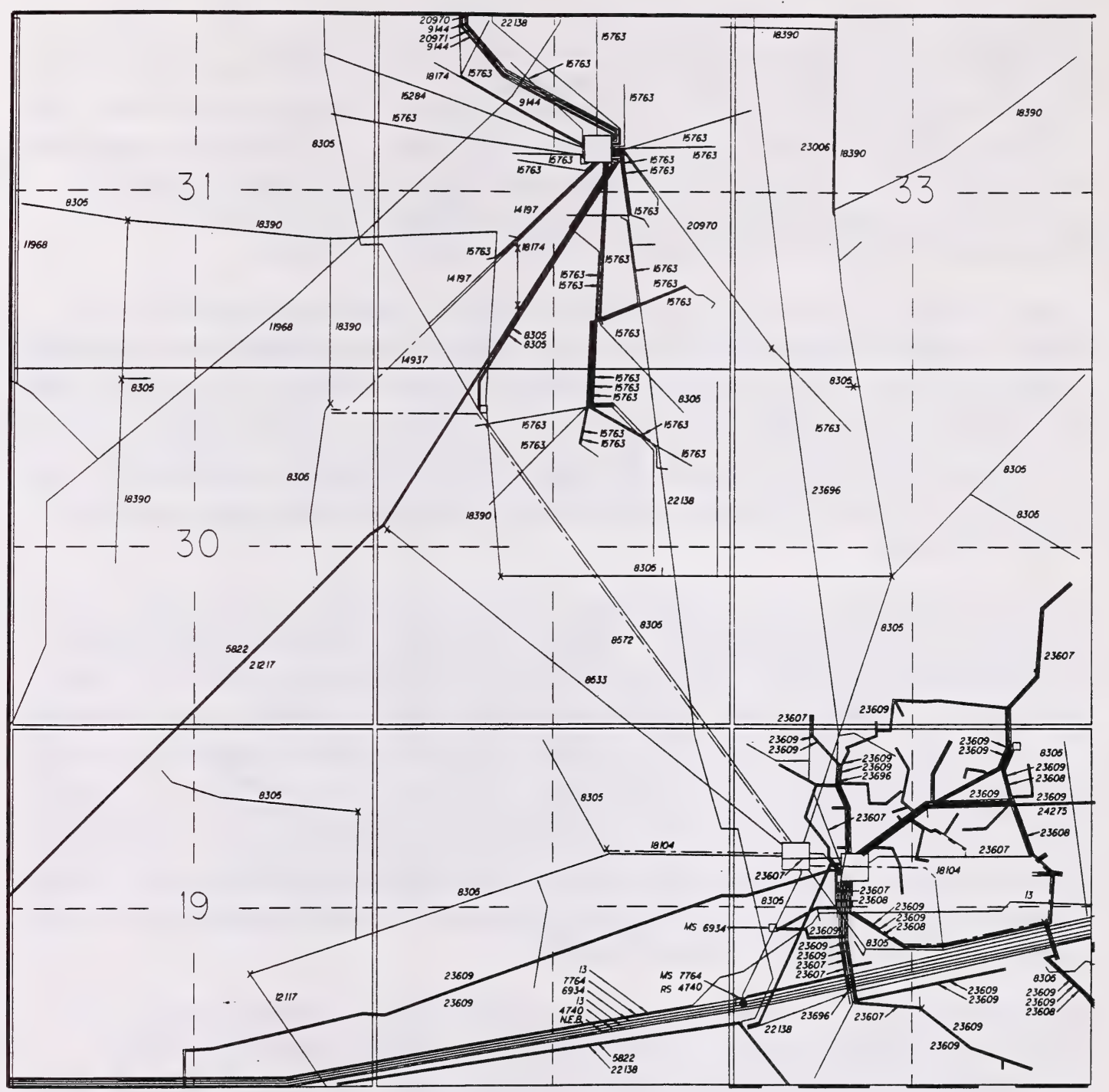

SCALE

IUEUB

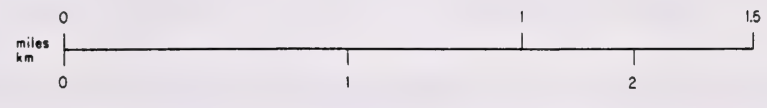

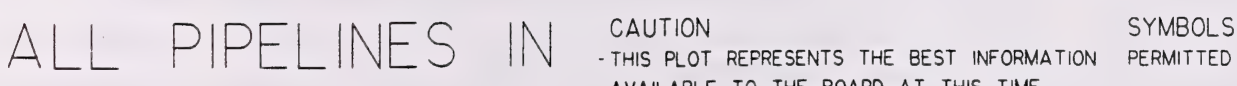
AVAILABLE TO THE BOARD AT THIS TIME.

NW1/4. O2O-OBW4 - SPECIFIC PIPELINE LOCATIONS SHOULD BE OBTAINED FROM SURVEY PLANS. OWNERS. AND FIELD OBSERVATION BEFORE DIGGING.

- LOW-PRESSURE GAS DISTRIBUTION LINES ARE NOT SHOWN. CONTACT THE GAS DISTRIBUTOR IN THIS AREA FOR LINE LOCATIONS.

LICENCED

DISCONTINUED.

$\triangle B A N D O N E D . O R$

$\triangle B A N D O N E D$ AND

PARTIALLY REMOVED 
The fragmentation, degradation and loss of natural prairie habitat, including upland grasslands and wetlands, has had significant impacts on the plant and animal species that depend on those habitats. Many of those species are now considered at risk in Canada, as determined by the Committee on the Status of Endangered Wildlife in Canada (COSEWIC), and other agencies and organizations. The next chapter focuses on these at risk species. 


\section{Chapter 1.6 Prairie Species at Risk}

There are a number of prairie species at risk. Species are considered endangered or threatened (e.g., Burrowing Owl, Piping Plover, Sage Thrasher); others have been extirpated (e.g., Blackfooted Ferret, Swift Fox, Greater Prairie Chicken) (COSEWIC 1996; IISD 1994, p71). The historical distribution and dispersal patterns of some species have been altered.

Within the Great Plains area of North America, 464 species of concern (212 animals, 234 plants) have been identified. This includes species considered: critically imperiled (117); imperiled (123) or rare (224) globally. Of those 464 species, 327 or $70.5 \%$ are either endemic or nearly endemic to the region (Ostlie et al. 1996, pg. viii). This means that "the existence of those species depends on their survival within the Plains, not somewhere else in the world" (ibid.). In addition, fully $42 \%$ of the endemic or near-endemic plant community types are critically imperiled (6\%), imperiled (20\%) or vulnerable (16\%). Nearly $45 \%$ of the mixedgrass prairie community types are considered at risk (ibid., p93).

Of 324 vascular species considered rare in Canada, about $25 \%$ are prairie species (Bradley and Wallis 1996, p15). Many rare or threatened prairie species are found only in special habitats such as sand dunes or badlands. These include western spiderwort, large-flowered paintbrush, sand verbena, Ord's Kangaroo Rat, Great Plains Toad, Western Hognose Snake, Loggerhead Shrike, Northern Prairie Skink and some species of grasshopper and tiger beetle (Trottier 1992, p31, 34; Bradley and Wallis 1996, p5; Wershler and Wallis 1986, p19). In Alberta, about 20\% of the rare plants in the grassland and parkland regions are found in sandy soils, principally in sand hill areas (Wallis 1987).

This and the next chapter reviews the listing of species by the Committee on the Status of Endangered Wildlife in Canada, the Status of Alberta Wildlife document and the Alberta Natural Heritage Information Centre.

\section{COSEWIC Listings of Species at Risk in Canada}

The Committee on the Status of Endangered Wildlife in Canada reviews and ranks species at risk into different risk categories, as follows:

- Extinct: a species that no longer exists.

- Extirpated: a species no longer existing in the wild in Canada, but occurring elsewhere.

- Endangered:

- Threatened: a species facing imminent extirpation or extinction.

- Vulnerable: a species likely to become endangered if limiting factors are not reversed. a species of special concern because of characteristics that make it particularly sensitive to human activities or natural events. 
COSEWIC reviews species for potential ranking only after a status report has been completed. There are many species, particularly plants and invertebrates, for which status reports have not yet been done. Many of these species could potentially be listed. To date, COSEWIC (1996) has ranked 272 animal and plant species at risk in Canada (Table 11). Thirty-nine (14.3\%) of them occur or were formerly present within the prairie biome of Alberta, Saskatchewan and Manitoba. One hundred and fifty (55\%) species are in the extinct, extirpated, endangered and threatened categories. Of those, 18 (12\%) occur within the prairie biome.

Table 11. Number of species at risk in Canada (COSEWIC 1996)

\begin{tabular}{|c|c|c|c|c|c|c|c|c|}
\hline Risk category & Mammals & Birds & Fish & $\begin{array}{c}\text { Reptiles and } \\
\text { Amphibians }\end{array}$ & Plants & Invertebrates & Lichens & Sub-total \\
\hline Extinct & 2 & 3 & 4 & 0 & 0 & 1 & 0 & 10 \\
\hline Extirpated & 5 & 1 & 2 & 1 & 2 & 0 & 0 & 11 \\
\hline Endangered & 12 & 16 & 4 & 4 & 27 & 0 & 1 & 64 \\
\hline Threatened & 9 & 6 & 12 & 3 & 35 & 0 & 0 & 65 \\
\hline Vulnerable & 24 & 19 & 38 & 8 & 31 & 0 & 2 & 122 \\
\hline Sub-total & 52 & 45 & 60 & 16 & 95 & 1 & 3 & 272 \\
\hline
\end{tabular}

About $77 \%$, or 24 of the 31 species at risk in Alberta, rely on prairie habitats. In Saskatchewan that figure is $83 \%$ (Table 12). According to Diamond (1993, p183), "prairie species can be described as nearly four times more likely than the national average to be at risk." At least onethird of the mammals and birds listed as endangered, threatened, or vulnerable by COSEWIC are associated with native prairies (World Wildlife Fund 1992). "Species now at risk are threatened most often by loss of habitat, so the current status of species of concern is usually an indicator of the availability of suitable habitat" (Diamond 1993, p181). 


\begin{tabular}{|c|c|c|c|c|}
\hline Risk category & Species & Alberta & Saskatchewan & Manitoba \\
\hline Extinct & Passenger Pigeon (was in Alberta but no nesting records) & $\mathrm{x}$ & $\mathrm{x}$ & $\mathrm{x}$ \\
\hline \multirow[t]{4}{*}{ Extirpated } & Black-footed Ferret & $\mathrm{x}$ & $\mathrm{x}$ & $\mathrm{x}$ \\
\hline & Grizzly Bear - prairie population & $\mathrm{x}$ & $\mathrm{x}$ & $\mathrm{x}$ \\
\hline & Swift Fox (historically common in Alberta prairies) & $\mathrm{x}$ & $\mathrm{x}$ & $\mathrm{X}$ \\
\hline & Greater Prairie Chicken & $\mathrm{x}$ & $\mathrm{x}$ & $\mathrm{x}$ \\
\hline \multirow[t]{9}{*}{ Endangered } & Burrowing Owl & $\mathrm{x}$ & $\mathrm{x}$ & $\mathrm{x}$ \\
\hline & Loggerhead Shrike - eastern population & & & $\mathrm{x}$ \\
\hline & Mountain Plover & $\mathrm{x}$ & $\mathrm{x}$ & \\
\hline & Peregrine Falcon & $\mathrm{x}$ & $\mathrm{x}$ & $\mathrm{x}$ \\
\hline & Piping Plover & $\mathrm{x}$ & $\mathrm{x}$ & $\mathrm{X}$ \\
\hline & Sage Thrasher & $\mathrm{x}$ & $\mathrm{x}$ & \\
\hline & Slender mouse-ear-cress & $\mathrm{x}$ & $\mathrm{x}$ & \\
\hline & small white lady's slipper & & & $\mathrm{x}$ \\
\hline & westem prairie white fringed orchid & & & $\mathrm{x}$ \\
\hline \multirow[t]{4}{*}{ Threatened } & Loggerhead Shrike - prairie population & $\mathrm{x}$ & $\mathrm{x}$ & $\mathrm{x}$ \\
\hline & sand verbena & $\mathrm{x}$ & $\mathrm{x}$ & \\
\hline & western blue flag & $\mathrm{x}$ & & \\
\hline & western spiderwort & $\mathrm{x}$ & & $\mathrm{x}$ \\
\hline \multirow[t]{21}{*}{ Vulnerable } & Black-tailed Prairie Dog & & $\mathrm{x}$ & \\
\hline & Ord's Kangaroo Rat & $\mathrm{x}$ & $\mathrm{x}$ & \\
\hline & Plains Pocket Gopher & & & $\mathrm{x}$ \\
\hline & Caspian Tern & $\mathrm{x}$ & $\mathrm{x}$ & $\mathrm{x}$ \\
\hline & Ferruginous Hawk & $\mathrm{x}$ & $\mathrm{x}$ & $\mathbf{x}$ \\
\hline & Least Bittern & & & $\mathrm{x}$ \\
\hline & Long-billed Curlew & $\mathrm{x}$ & $\mathrm{x}$ & \\
\hline & Red-headed Woodpecker & & $\mathrm{x}$ & $\mathrm{x}$ \\
\hline & Short-eared Owl & $\mathrm{x}$ & $\mathrm{x}$ & $\mathrm{x}$ \\
\hline & Eastern Short-horned Lizard & $\mathrm{x}$ & $\mathrm{x}$ & \\
\hline & Eastern Yellow-bellied Racer & & $\mathrm{x}$ & \\
\hline & Northern Prairie Skink & & & $\mathrm{x}$ \\
\hline & Bigmouth Buffalo (fish) & & $\mathrm{x}$ & $\mathrm{x}$ \\
\hline & Bigmouth Shiner & & & $\mathrm{x}$ \\
\hline & Chestnut Lamprey & & $\mathrm{x}$ & $\mathrm{X}$ \\
\hline & Rosyface Shiner & & & $\mathrm{x}$ \\
\hline & Silver Chub & & & $\mathrm{x}$ \\
\hline & hare-footed loco weed & $\mathrm{x}$ & & \\
\hline & smooth goosefoot & $\mathrm{x}$ & $\mathrm{x}$ & $\mathrm{X}$ \\
\hline & soapweed & $\mathrm{X}$ & & \\
\hline & western silver-leaf & . & & $\mathrm{x}$ \\
\hline \multicolumn{2}{|c|}{ Sub-Total } & 24 & 25 & 26 \\
\hline \multicolumn{2}{|r|}{ Total } & \multicolumn{3}{|c|}{75} \\
\hline \multicolumn{2}{|c|}{ Total number of species listed at risk in the province (COSEWIC 1996) } & 31 & 30 & 34 \\
\hline \multicolumn{2}{|r|}{ Proportion of prairie vs. total species at risk in the province } & $77.4 \%$ & $83.3 \%$ & $76.4 \%$ \\
\hline
\end{tabular}




\section{The Status of Alberta Wildlife:}

Alberta Environmental Protection (1996b) groups Alberta's mammal, bird, amphibian and reptile species into four categories, as follows:

- RED-LISTED Species: $\quad$ Current knowledge suggests that these species are at risk. Populations of these species have declined, or are believed to have declined, to nonviable levels, or show a rate of decrease indicating that they are at immediate risk of declining to nonviable levels in Alberta.

- BLUE-LISTED Species: . Current knowledge suggests that these species may be at risk. They are particularly vulnerable because of non-cyclical declines in population or habitat, or reductions in provincial distribution.

- YELLOW-LISTED Species: These are sensitive species that are not currently believed to be at risk, but may require special management to address concerns related to naturally low populations, limited provincial distributions, or demographic/life history features that make them vulnerable to human-related changes to the environment.

- GREEN-LISTED species: These species are not considered at risk. Their populations are stable and their key habitats are generally secure at present.

- STATUS UNDETERMINED: This category includes those species not known to be at risk but for which insufficient information is available at present to determine status.

The environmental change in the prairies of Alberta is underscored by the large proportion of species there that are currently at risk. Of the 9 species RED-LISTED for the province in 1996, there are $7(77.8 \%)$ that depend on prairie habitats (Table 13$)$. One-half $(50 \%)$ of the BLUE-LISTED species are also found in the prairies (Table 13). 
Table 13. The Status of Alberta Wildlife (Alberta Environmental Protection 1996b)

\begin{tabular}{|c|c|c|}
\hline Wildlife Group & RED-LISTED Species & BLUE-LISTED Species \\
\hline \multirow[t]{3}{*}{ AMPHIBIANS } & Canadian Toad* & Plains Spadefoot Toad* \\
\hline & Great Plains Toad* & Spotted Frog \\
\hline & Northern Leopard Frog* & \\
\hline \multirow[t]{3}{*}{ REPTILES } & & Prairie Rattlesnake* \\
\hline & & Short-horned Lizard* \\
\hline & & Western Hognose Snake* \\
\hline \multirow[t]{9}{*}{ BIRDS } & Burrowing Owl* & Bay-breasted Warbler \\
\hline & Peregrine Falcon* & Black-throated Green Warbler \\
\hline & Piping Plover* & Cape May Warbler \\
\hline & Whooping Crane & Ferruginous Hawk* \\
\hline & & Long-billed Curlew* \\
\hline & & Sage Grouse* \\
\hline & & Short-eared Owl* \\
\hline & & Sprague's Pipit* \\
\hline & & Trumpeter Swan \\
\hline \multirow[t]{6}{*}{ MAMMALS } & Swift Fox* & Grizzly Bear \\
\hline & Wood Bison & Northern Long-eared Bat \\
\hline & & Ord's Kangaroo Rat* \\
\hline & & Red-tailed Chipmunk \\
\hline & & Woodland Caribou \\
\hline & & Wolverine \\
\hline Total & 9 & 20 \\
\hline Species occurring within the prairie biome & 7 & 10 \\
\hline Proportion of prairie species & $77.8 \%$ & $50 \%$ \\
\hline
\end{tabular}




\section{ANHIC Tracking Lists of Alberta Species:}

The Alberta Natural Heritage Information Centre (ANHIC) collects, evaluates and makes available information on Alberta's elements of biodiversity - plants, animals and natural communities. Plant and animal species are evaluated and ranked on their province-wide status using a system that was developed by The Nature Conservancy and is in use throughout North America. Ranking is based primarily on the number of occurrences, since that is frequently the only information available. A scale of one to five is used to rank elements. An element can be uncommon everywhere (i.e., on a global scale) but common provincially, or common globally but rare in the province. A global rank (G-rank) is first applied for each species across its entire range and then a sub-national or provincial (S-rank) is applied.

\section{Species' Provincial Ranks:}

S1: 5 or fewer occurrences in the province or only a few remaining individuals or may be imperiled because some factor of its biology makes it especially vulnerable to extirpation.

S2: 6-20 occurrences or with many individuals in fewer occurrences; or may be susceptible to extirpation because of some factor of its biology.

S3: 21-100 occurrences, may be rare and local throughout the provincial range, or in a restricted provincial range (may be abundant in some locations or may be vulnerable to extirpation because of some factor of its biology).

S4: apparently secure under present conditions, typically more than 100 occurrences but may be fewer with many large populations; may be rare in parts of its provincial range, especially peripherally.

S5: demonstrably secure under present conditions, more than 100 occurrences, may be rare in parts of its provincial range, especially peripherally.

The Alberta Natural Heritage Information Centre (ANHIC) has developed tracking lists for priority vascular plant and moss species. These lists are updated as new information becomes available. A tracking list includes elements (e.g., species) of high priority; generally those ranked S1, S2, S1S2 or occasionally S3. Tracking lists for other elements of biodiversity are also being developed and some of those elements have also been mapped (e.g., Leopard Frog).

Of the plant species on the tracking list, there are 92 with mapped locations in the Grassland Natural Region (ANHIC 1996b). There are also two animal species with mapped locations. These locations are plotted on Map 5. Table 14 illustrates the distribution of these species; some occur in more than one subregion. Mapped locations record where a trackable species population has been documented. Sometimes these records may be historical in nature, as the population may no longer be present. Mapped locations of trackable species are constantly being updated as information becomes available. 
Table 14. Species on the tracking list mapped as occurring within the Grassland Natural Region (ANHIC 1996b).

\begin{tabular}{|c|c|c|c|c|c|c|}
\hline Subregion & S1 species & S1? species & S2 species & S2? species & S1S2 species & Total \\
\hline Dry Mixedgrass & 16 & 1 & 31 & 1 & 2 & 51 \\
\hline Foothills Fescue & 3 & 1 & 23 & 3 & 3 & 33 \\
\hline Northern Fescue & 1 & 0 & 4 & 1 & 0 & 6 \\
\hline Mixedgrass & 2 & 0 & 21 & 1 & 2 & 26 \\
\hline Number of species* & 20 & 2 & 62 & 4 & 6 & 94 \\
\hline
\end{tabular}

*Figures reflect the number of different species that have mapped locations. Since some of the species occur in more than one subregion, the numbers in each column are not additive.

Locations with concentrations of rare plant species include: (a) extreme southeast Alberta [e.g., Milk River and Pakowki Lake area], (b) river valley areas [e.g., Dune Point area on the Red Deer River, sites along the Oldman River], (c) the Suffield area, and (d) the Ross Lake area (Map 5). The trackable species that are mapped are listed in Appendix 1.

The following discussion focuses on those COSEWIC-ranked species at risk that were or are currently found on the Canadian prairies.

\section{Passenger Pigeon (Extinct)}

The extinction of the Passenger Pigeon is one of the best known examples of human-caused loss of a species. Once one of the most numerous birds in North America, it came under excessive pressure with the growth of cities, the clearing of deciduous forests by European settlers and over-hunting in the 19th century. In 1851, for example, "nearly two million pigeons were shipped to market by rail from a single site in New York State" (Burnett et al. 1989, p10). The following quotation reflects the sentiment of the day:

"The passenger pigeon needs no protection. Wonderfully prolific, having the vast forests of the north as its breeding grounds, travelling hundreds of miles in search of food, it is here today, and elsewhere tomorrow, and no ordinary destruction can lessen them or be missed from the myriads that are yearly produced" [Committee report on the game bill to the State Legislature of Ohio, 1857, as cited in Nature Canada (1996, p45)]

The three to five billion Passenger Pigeons that lived in the forests and grasslands of Canada and the northern U.S. were decimated within decades. By the 1890s these birds were rare. "No one did anything until it was too late and, in 1914, the last Passenger Pigeon died in a Cincinnati zoo" (Burnett et al. 1989, p10). 

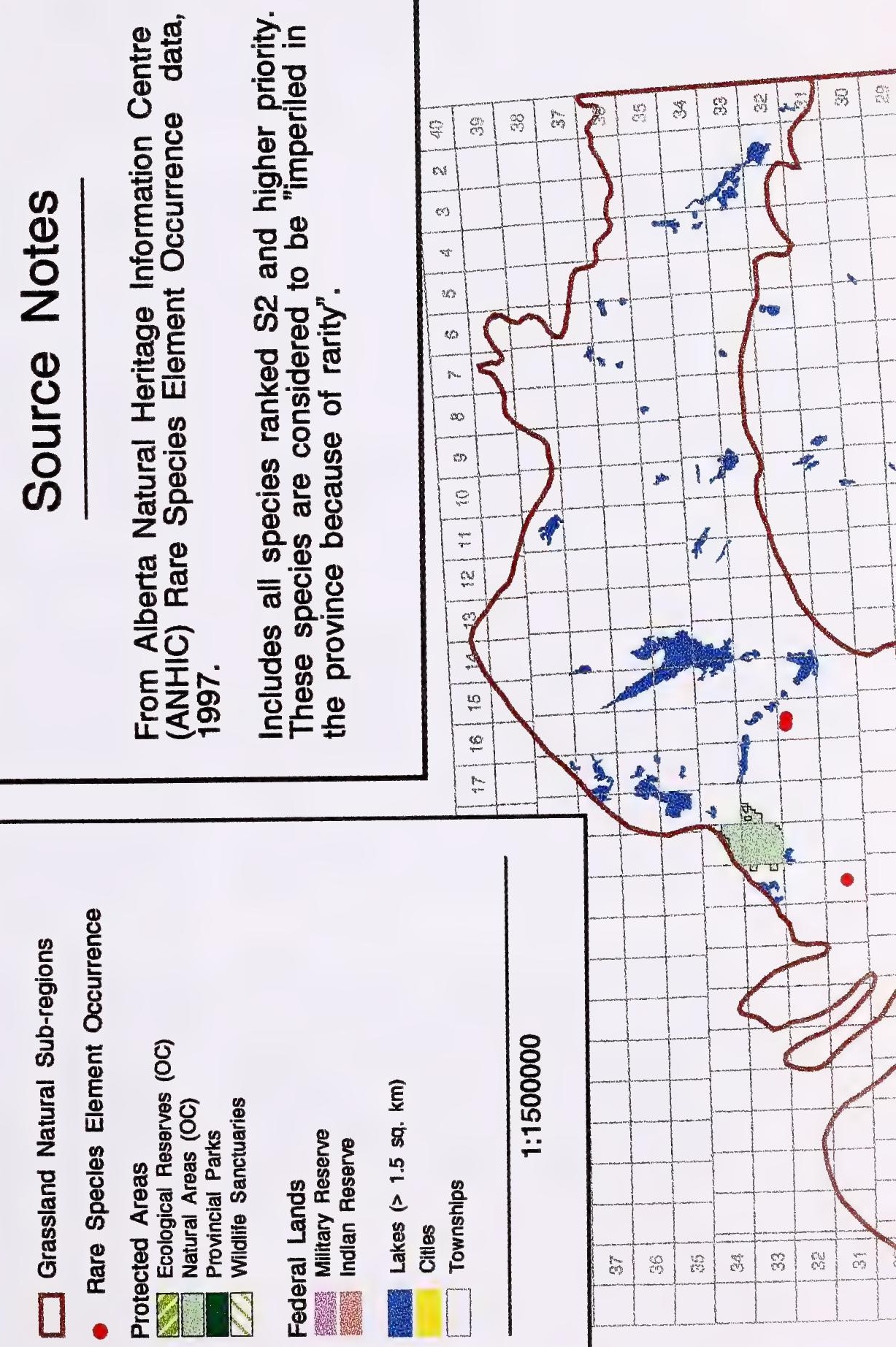


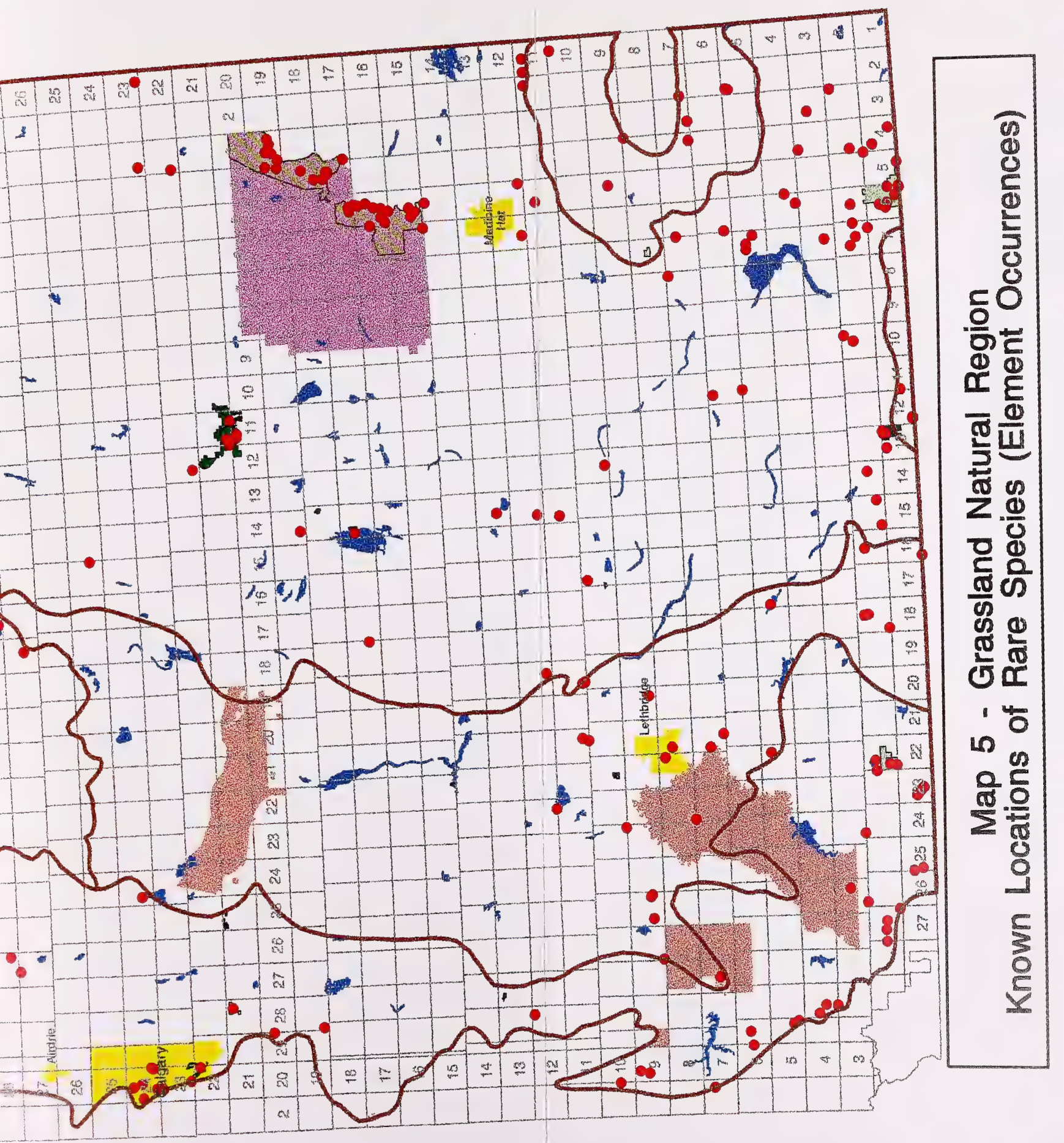




\section{Black-footed Ferret (extirpated)}

The Black-footed Ferret occurred throughout most of the Great Plains. This species is now a rare inhabitant of the prairies of North America and is one of the rarest mammals in the world (RENEW 1996, p13). Ferrets depend on the disappearing Black-tailed Prairie Dogs for $90 \%$ of their food. A family of four will consume over 700 prairie dogs per year (NPSC 1996). Ferrets also use prairie dog burrows for shelter and raising young.

The rapid decline of the Black-footed Ferret has been linked to habitat fragmentation as a result of intense farming and grazing practices and to large-scale prairie dog eradication efforts, including poisoning campaigns (Forsyth 1983, p71; NPSC 1996; Westworth \& Associates 1993a, pN-2). Prairie dogs now occupy less than one percent of their historic range. The Black-footed Ferret has been extirpated from the southern Canadian prairies and has nearly became extinct in the United States (Ostlie et al. 1996, p41). The last known population in the wild was found at Meeteetse, Wyoming, in 1981 and included 18 animals (NPSC 1996). To save the species from extinction, these individuals were trapped and bred in captivity. In 1991, 49 were reintroduced in Wyoming, and 40 ferrets were released in Montana and 36 in South Dakota in 1994(ibid.). "Plans for eventually reintroducing the extirpated Black-footed Ferret to Canada depend on the long-term viability of prairie dog populations" (Trottier 1992, p21).

\section{Grizzly Bear - prairie population (extirpated)}

Grizzly Bear were abundant in the prairie region of Alberta during the 1700 s, "especially along rivers that had suitable foods including berries, roots, carcasses of drowned bison and an abundance of other prey species" (Nagy and Gunson 1990, p2). Grizzlies once occurred on the prairies as far east as the Red River valley in Manitoba. During the 1800s, explorers and fur traders shot grizzlies for safety reasons, for sport and for the money their pelts would bring. The species was still abundant in areas of southern Alberta in the 1850s. "One area in Alberta where grizzlies remained common for a longer period of time was the Cypress Hills. The [aboriginal peoples] did not hunt this area primarily because of religious taboos" (ibid.). But, during the 1870 s, fur trader hunting decimated this population too. One trader's share of the grizzly kill in the Hills in 1871 was 750 skins (ibid., p2).

The beginnings of settlement, ranching and farming during the 1870s spelled the end of the Grizzly Bear on the prairies. By the 1880s they were all but gone from that part of Alberta. Sightings in southern Alberta east of the Rockies were considered abnormal by the 1890s. "By the 1950s, their range had receded to about three-quarters of that occupied during the pre-1900 times" (ibid., p8). In 1991, the prairie population of the grizzly was added by COSEWIC to the list of species extirpated in Canada. In Alberta, the Grizzly Bear still occurs in the mountains, foothills and boreal forest and populations in these areas are considered "relatively stable outside the national parks since 1980" (AEP 1996, p21).

\section{Swift Fox (extirpated)}

Historically, the Swift Fox ranged from southern Canada to the panhandle of Texas, and from 
northwest Montana to western Minnesota. Swift Fox were quite common in southwest Saskatchewan, southern Alberta and southeast British Columbia. The species inhabited southern Alberta north to about Camrose (latitude 53 degrees). Swift Foxes were normally found in "the dryer prairies with characteristic aridity, scanty grass cover, sagebrush and greasewood" (Soper 1964, p274). They also inhabited areas of mixed agricultural use, but in these areas, population densities were lower. Prairie dog towns were the preferred habitat of Swift Fox (NPSC 1996). Swift Fox populations are now found in only a fraction of their former range; however, populations are still healthy in the southern United States (NPSC 1996).

In pre-settlement times, the Prairie Wolf may have controlled Coyote numbers, thereby reducing predation on the Swift Fox. The "elimination of wolves [from the prairies] is believed to have resulted in an increase in Coyotes, which in turn led to increased predation on Swift Foxes and contributed to that species' decline" (Bradley and Wallis 1996, p11). The disappearance of the native prairies due to agricultural, industrial and urban development has also reduced Swift Fox numbers (NPSC 1996). Their dens have been ploughed over and native grasses replaced with tall cereal crops. Such crops are unsuitable habitat for foxes or the small rodents, birds and insects that make up their prey. Swift Foxes have also been trapped for their pelts. Fur traders took about one thousand pelts per year between 1850 and 1870 (Burnett et al. 1989, p157). As a result of habitat change, trapping and predator-control programs, the Swift Fox was eliminated from Alberta almost 70 years ago. This species disappeared entirely from Canada by about 1928 (Burnett et al. 1989, p157).

"Re-introduction efforts between 1983 and 1994 have resulted in more than 750 releases of the Swift Fox in Alberta and Saskatchewan" (RENEW 1996, p18). Indications are that the reintroduction program is having some success, with a current population of about 200 foxes (Klausz et al. 1996). Swift Fox has been removed from the extirpated list for Alberta and moved to the province's RED LIST as a species at risk. It is considered an "endangered animal" with "less than 150 animals re-established in Alberta" and "the ability to maintain [the] population in prairie Canada is uncertain" (AEP 1996).

\section{Greater Prairie Chicken (extirpated)}

The Greater Prairie Chicken is not known to have existed in Canada before European settlement (Hjertaas et al. 1993). In the United States, this species inhabited extensive natural grasslands that were open to bushy. It also used lightly grazed grasslands located near bushy natural grasslands (Microsoft Internet Explorer 1996). The controlled fires, removal of Plains Bison herds and expanded food supply (e.g., waste grain) that came with settlement created suitable habitat for the Greater Prairie Chicken. This is thought to have resulted in the species expanding its range into Canada from Minnesota and North Dakota (Johnston and Smoliak 1976, p153).

Between the 1890s and the mid-1920s, the Greater Prairie Chicken "reached a population density [in the western prairies] estimated at over a million" (ibid., p154). Up to the mid-1920s, it was not uncommon in southern and central Alberta, but by the late 1930s, it had essentially

disappeared from Canada. Among the reasons for its decline were the conversion of grassland to cropland, heavy cattle grazing, drought, harsh winters, increased hunting pressure and 
competition from pheasants (McNicholl 1988; Trottier 1992; Salt and Salt 1976, p111). The species is now essentially confined to the north-central United States (Salt and Salt 1976, p111). It has vanished from Ontario, Manitoba and Alberta, but there were about 15 sightings in Saskatchewan between 1965 and 1977 (Microsoft Internet Explorer 1996). It is considered extirpated from Canada, although the sightings from Saskatchewan suggest that some individuals may still be found, possibly during migration.

\section{Burrowing Owl (endangered)}

COSEWIC (1996) lists the Burrowing Owl as an endangered species in Canada. It is unique among raptors in Canada for its habit of nesting in burrows. It relies almost entirely on the excavations of burrowing animals for this purpose. A pair of owls may use the same nesting area, and often the same burrow, year after year (RENEW 1996, p6). Thus, the availability of burrows and the presence of burrowing mammals are critical components of its habitat. This owl prefers open land with short vegetation in which to nest, with tall grassland nearby for hunting mice, voles, insects and other prey. Habitat size may also be important. A five-year study of Burrowing Owls in Saskatchewan found that "larger pastures contain more breeding pairs" than smaller ones. Populations on smaller pastures were also found to be more likely to become extirpated, possibly due to increased predation levels (James 1993).

From 1890 to the mid-twentieth century, the Burrowing Owl seems to have been common in some districts of the prairies, but uncommon or scarce overall. "The breeding population is historically sparse; increasing during the early to mid-1900s when mixed farming was prevalent, and declining with the intensification of agriculture" (Poston et al. 1990, p.90). A substantial decline in the population has occurred since the 1950s. This decline has been linked to the fragmentation and loss of prairie habitat, reduced prey due to pesticide use (e.g., Carbofuran an insecticide used for grasshopper control) and predation (AFGA 1993, p1; RENEW 1996, p6). "The loss, fragmentation and general degradation of nesting habitat is believed to be the single most important factor influencing the number of owls that nest in Canada". (Scobie 1994, p1). Also implicated is "control of burrowing mammals that provide nesting habitat" (Poston et al. 1990, p.90). Road kills, shooting, secondary poisoning and predation are additional factors (ibid.).

The Burrowing Owl population on the prairies is scattered over a large area of southern Alberta, Saskatchewan and Manitoba. Most of the owls are in Alberta and Saskatchewan (RENEW 1996, p7). In the early 1990s, about 800 pairs of Burrowing Owls were present in Alberta; in Saskatchewan there were about twelve hundred (WWF ca.1993). For the Alberta population, the Dry Mixedgrass Subregion was found to contain about $72 \%$ of the nest sites (Table 15), (AFGA 1993).

The extent of the breeding range of Burrowing Owls in Canada is diminishing (AFGA 1993, p2), and the numbers of these owls continue to decline despite the efforts of a multi-agency recovery team (Hjertaas et al. 1995; Holroyd et al. 1993). In Manitoba, for example, from 76 known pairs in 1982, the population dropped to 8 pairs in 1994 (Hjertaas 1996). The estimated total number of breeding pairs in Canada is now between 1015 and 1695, an historically low number. AEP 
(1996, p19) concludes that the "population [is] declining dramatically in prairie habitats across Canada." In Alberta, the Burrowing Owl is on its RED LIST and is considered to be an "endangered animal" (AEP 1996, p19). The Alberta population is estimated at "700 to 900 breeding pairs (1995) and declining" (ibid.).

Table 15. Alberta Burrowing Owl nest occurrences (1981-1993) by Ecoregion*. [adapted from AFGA 1993, p14]

\begin{tabular}{|c|c|c|}
\hline Ecoregion & Number of nests & $\%$ of total \\
\hline Dry Mixedgrass & 480 & 72 \\
\hline Mixedgrass & 161 & 24 \\
\hline Fescue Grass & 14 & 2 \\
\hline Aspen Parkland & 12 & 2 \\
\hline Total & 667 & 100 \\
\hline \multicolumn{3}{|c|}{$\begin{array}{l}\text { *Note: Strong and Leggat (1992) divided Alberta into } 13 \text { ecoregions. The Dry Mixedgrass and Fescue Grass } \\
\text { Ecoregions of Strong and Leggat correspond fairly closely with the Dry Mixedgrass and Foothills Fescue } \\
\text { Subregions, respectively, of this report. The Mixedgrass Ecoregion of Strong and Leggat includes the Mixedgrass } \\
\text { Subregion of this report, but does not recognize the Northern Fescue Subregion. }\end{array}$} \\
\hline
\end{tabular}

\section{Loggerhead Shrike (endangered/threatened)}

The eastern population of this species is considered endangered; the prairie population is considered threatened (COSEWIC 1996). This species prefers open, short-cropped grassland habitats "for finding and capturing its principal prey of large insects, mice and even small songbirds. Shrub thickets are also essential for perching and nesting" (Trottier 1992).

Several shrike species have been declining in numbers in both North America and Eurasia (RENEW 1996, p9). In eastern North America, in states "such as New York, Pennsylvania and Virginia, populations have either disappeared or been reduced to mere scattered pairs" (Avian Science and Conservation Centre 1996). In Canada, there have been serious declines in the numbers of shrikes on breeding grounds (Johns et al. 1994). Prairie populations, however, appear to have stabilized in all areas except southwest Manitoba, where numbers continue to decline (Scobie 1994, p1; RENEW 1996, p9).

Declines in Loggerhead Shrike numbers are believed to be due primarily to loss of habitat on both wintering and breeding areas. This, coupled with the use of fertilizers and pesticides, has resulted in a diminished diversity and availability of prey (ibid.). The Loggerhead Shrike is on the YELLOW A LIST for Alberta. These are species "for which there has been concern expressed over long term declines in their numbers" (AEP 1996, p9). The "population is low, poorly understood and probably has declined in recent years" (ibid., p23). 


\section{Mountain Plover (endangered)}

In the late 1800 s the species was reportedly common along the 49th parallel, near the Milk River and Frenchman River (Wershler and Wallis 1986, p17). Mountain Plover populations have declined somewhat in recent years throughout their North America range (Microsoft Internet Explorer 1996), but they still "remain plentiful in Montana, Colorado and Wyoming (Shank 1996, p7):

Where present, this shorebird prefers to nest and feed in heavily-grazed native grassland. "Black-tailed Prairie Dog towns are preferred habitat farther south in Montana grasslands, but [recent] searches of similar habitat in southwest Saskatchewan have failed to locate any Mountain Plovers" (Trottier 1992, p20). Sightings near Val Marie suggest it may occur there (Poston et al. 1990). The species was first documented in Alberta in 1979 (ibid.). A few pairs nest in the Lost River area of southeast Alberta. The Lost River population inhabits heavily grazed, grazed and recently burned grassland on flat terrain. Mountain Plovers in Alberta "show a preference for grassland used as pasture during the winter immediately prior to the nesting season" (Wershler and Wallis 1986, p18). The Mountain Plover is extremely rare in Alberta (Patriquin 1993); about seven pairs were found in 1994 (RENEW 1996, p16). The Lost River population has fluctuated from "a high of 11 adults with at least six nests in 1981 to one nesting pair in 1985, and the nest failed" (Wershler 1987 as cited in Poston et al. 1990). It is on the YELLOW B LIST for Alberta, as a species that is at the extreme northern edge of its breeding range and, therefore, naturally rare, with "4-6 pairs known to breed in [the] province" (AEP 1996, p27).

\section{Peregrine Falcon (endangered)}

The anatum subspecies of the peregrine inhabits the area south of the tree-line. "In the 1950's and 1960's, this subspecies underwent a significant decline" (Poston et al. 1990, p82). In Alberta, in the mid-1970s, less than 5 of 73 historical nest sites were occupied (Court et al. 1996). The decline has been linked to a reduced reproductive rate caused by ingesting prey contaminated by DDT and other organochlorines. "With restrictions on the use of DDT in Canada and the United States, combined with intense captive-breeding and release efforts, core populations of peregrine are now being naturally sustained or increased in all areas where the species was historically found" (RENEW 1996, p10). The Peregrine Falcon remains on the RED LIST for Alberta, as an "endangered animal" with less than 50 breeding pairs (AEP 1996, p19). "Continued provincial recovery of this species will depend on declining pesticide levels in prey, releases of captive-reared chicks into southern Alberta and protection of wetland feeding areas" (ibid., p19).

\section{Piping Plover (endangered)}

This small plover depends on undisturbed natural shorelines to nest and raise it's young (Alberta Forestry, Lands and Wildlife 1990). "Pebble beaches and mudflats exposed by the receding waterlines of prairie sloughs and lakes is the critical habitat for this species. Availability of this habitat is variable from year to year depending on rainfall, so it is often difficult to predict just where birds will be found nesting" (Trottier 1992, p28). "Because this plover rests, feeds and 
raises young on the open beach flats, it is very vulnerable to disturbance from recreational activity, livestock trampling, and water-level stabilization projects that permanently flood shoreline habitat" (ibid., p28). Its habitat preferences also make it vulnerable to predators (RENEW 1996, p11).

Over much of their geographic range, Piping Plovers are in direct competition with people for open sand or pebble beaches, particularly in June and July when young birds are active. Human activities such as driving motorized vehicles on beaches used by the birds can result in nest abandonment or destruction. Agricultural development (e.g., drainage, cultivation) around lakes and sloughs has reduced the amount of suitable habitat available for nesting plovers. Changes to water levels such as those associated with lake stabilization projects are detrimental to this species (Microsoft Internet Explorer 1996), since high water levels can eliminate nesting habitat. At some beaches, cattle have trampled nests or young birds. Chicks may have difficulty climbing out of the deep holes left by livestock along lake shores (Alberta Forestry, Lands and Wildlife 1990).

The numbers of Piping Plovers have been decreasing throughout their range (Microsoft Internet Explorer 1996). This species is currently designated under the Alberta Wildlife Act and listed by COSEWIC as an endangered species. It is "threatened or endangered throughout North America" (AEP 1996, p19). In 1991, the entire prairie population of plovers was estimated at 1437 birds (RENEW 1996, p11). It occurs rarely and locally within Alberta. During a survey in 1986, researchers recorded "approximately 100 breeding pairs and 88 non-breeding birds at 28 different sites" in Alberta (Alberta Forestry, Lands and Wildlife 1990). "Most of the breeding birds were found near Provost, Hanna and Medicine Hat" (ibid.). There are now an estimated 100 to 150 breeding pairs in Alberta (AEP 1996). Breeding pairs are often clustered in suitable lake shore habitat. Patriquin (1993, p29) lists this species and the Baird's Sparrow as the two top priority bird species of the prairie biome. "Recovery requires protection from human disturbance and management of key shoreline nesting habitats" (AEP 1996, p19).

\section{Sage Thrasher (endangered)}

In Alberta, breeding habitat is confined to the semi-arid plains found in the southeast of the province. The species also breeds in southern British Columbia and southwest Saskatchewan. Salt and Salt (1976, p321) considered this species to be a rare vagrant in Alberta and at present there is insufficient information available to determine its status (AEP 1996). Populations of Sage Thrashers in Canada vary considerably from year to year, the maximum recent numbers being about five to 12 pairs.

In the past, the numbers of this species in Canada may have been as high as 30 pairs (Microsoft Internet Explorer 1996). During the breeding season, Sage Thrashers prefer sagebrush habitats, where sagebrush is the dominant plant species (Semenchuk 1992, p233). A major limiting factor is loss or alteration of habitat due to agricultural, mining or residential developments. Mowing, burning, herbicide spraying and overgrazing are detrimental to this species (Microsoft Internet Explorer 1996). 


\section{Slender mouse-ear cress - Halimolobos virgata (endangered)}

The following is taken from Smith (1991). Halimolobos virgata is distributed from "southeastern Alberta to southwestern Saskatchewan in Canada and southward in the United States to eastern Idaho, Wyoming, Utah, Colorado and California" (p3). It is a rare species throughout much of its range. In Alberta, the species is found primarily in the Dry Mixedgrass Subregion. It is "restricted to southeastern areas along the Saskatchewan border from the South Saskatchewan River north of Medicine Hat to the Cypress Hills" (p3).

This species occurs "in sandy alkaline soils on dry benches and eroded hillsides" (p4). The only specimens collected in Alberta after 1900 were from a site along the South Saskatchewan River, near the Saskatchewan border. This site was a dry sagebrush-covered silt flat just above river level and a specimen was collected there in 1978. Visits to the site in 1991 revealed no specimens, although the species could still be present.

\section{Sand verbena - Abronia micrantha (threatened)}

The following is taken from Smith and Bradley (1990a). This species is "distributed in widely scattered localities in mixed grassland from southeastern Alberta to southwestern Saskatchewan, south to eastern Montana, Utah, Nevada, New Mexico, South Dakota, western Kansas and northern Texas" (p6). In addition, it is found in North Dakota, Wyoming, Colorado, Arizona and California.

In Alberta, the range of sand verbena extends east of Lethbridge, northeast to south of Empress, and south to the U.S. border in the Manyberries area (p6). This species has been observed at the following sites: Lost River, Lower Bow, Purple Springs, South Saskatchewan River and Wolf Island (p6). "The total Alberta population is estimated to be under one thousand plants" (p10). The only other population in Canada, outside Alberta, is in southwestern Saskatchewan.

Sand verbena is found "in dry habitats, particularly in loose alluvial sands of dune and sand hill areas. Some element of active sand is usually required. The largest populations are on hardpacked sand on level terrain but it also occurs on south, west, and east-facing slopes and along dune ridge tops" ( $\mathrm{p} 7)$. Populations of sand verbena are dependent on major active sandy areas. Much of this habitat has been cultivated or stabilized, perhaps due to lack of fire.

\section{Western blue flag - Iris missouriensis (threatened)}

The following is taken from Wallis (1989). Western blue flag occurs "from southwestern Alberta, Washington, Idaho and Montana east to North Dakota and Minnesota and south through Nebraska, South Dakota, Wyoming, Colorado, Oregon, Nevada and Utah to southern California, Arizona, New Mexico and Coahuila in northern Mexico" (p4). "In Canada, western blue flag naturally occurs only in small populations in the extreme southwestern corner of Alberta so it is considered rare from a national perspective. Only one species of iris grows wild in Alberta" (p2). Populations are known at Whiskey Gap, Carway, Mary Lake and Police Outpost Provincial Park. Surveys conducted in 1987 and 1989 show a total Alberta population of less than 7500 stems at six different sites. 
"While it is abundant in portions of the Rocky Mountain states, there are large areas of its range where it is very localized. Its moist meadow habitats have been referred to as threatened or endangered ... The western blue flag's native foothills grassland habitats in Alberta have suffered considerable modification after European settlement and they continue to be converted to non-native species" (p2). Of the $750 \mathrm{~km}^{2}$ portion of the Foothills Fescue Subregion in which western blue flag may have occurred prior to European settlement, "less than $100 \mathrm{~km}^{2}$ remains in an uncultivated condition" (p13). Only a small fraction of the natural habitats remaining in that subregion are suitable for western blue flag. The "main limiting factors for this species are its natural narrow environmental tolerance and loss of natural habitat. It occupies a very narrow habitat niche between dry uplands and permanent wetlands" (p9).

\section{Western spiderwort - Tradescantia occidentalis (threatened)}

The following is taken from Smith and Bradley (1990b), except as noted. Western spiderwort is "common on the Great Plains of the U.S., from Montana to Utah eastward to western Wisconsin, and southward as far as Mexico (p3). It is known in Canada from southeastern Alberta, southcentral Saskatchewan and southwestern Manitoba. Populations from southeast Alberta were first reported in 1986 from a site in the Pakowki Lake sand hills, to the northeast of Pakowki Lake. In 1988, two other populations were found in the Pakowki dunes. Detailed field investigations of appropriate habitats found no additional populations. The Pakowki Lake sand hills cover an area of about $49 \mathrm{~km}^{2}$ in the mixed grassland area of southeast Alberta. Two small populations totalling less than 50 plants were found in Saskatchewan in 1991 (Thorpe and Godwin 1992).

The western spiderwort is restricted to sand dune areas and appears to require some element of active or drifting sand. Found only in Manitoba, Saskatchewan and Alberta in Canada, the total Canadian population is estimated to be less than two thousand plants. Threats may include invasion of exotic species; an extensive leafy spurge invasion was noted near the largest Saskatchewan population. Although cattle will eat the plants, it unknown if this is detrimental. The main limiting factors affecting this species are its narrow preference for unstabilized sites within dune fields and loss of natural habitat through factors such as fire control. The active sand surface of some dunes in the Pakowki Lake area has been substantially reduced in recent years (Wallis 1988). Continued stabilization of the dunes at Pakowki Lake would likely be detrimental to the long-term survival of the western spiderwort (Wallis and Wershler 1988).

\section{Black-tailed Prairie Dog (vulnerable)}

The Black-tailed Prairie Dog is the most abundant and widely distributed of five species of prairie dogs found in North America. It is found throughout the Great Plains from southern Canada to just inside Mexico. The western edge of its range is along the Rocky Mountains, and the eastern edge follows the natural boundary between tall and mid-grass prairie (Nebraska Game \& Parks Commission 1995). In Canada, the only known populations are located in the "Val Marie grasslands" along the Frenchman River Valley in southwest Saskatchewan. Soper (1964, p389) notes that there was "some possibility of occurrence of prairie dogs in Alberta"; and, "there may well have been small outposts in Alberta in earlier times." At present, there are no known populations of prairie dogs in Alberta and it is not on the list of Alberta mammals (AEP 1996). 
Black-tailed Prairie Dogs live in colonies or "towns" that range in size from as small as one acre up to several thousand acres. In the late $1800 \mathrm{~s}$, "prairie dog colonies [inhabited] between 40 to 100 million hectares of native mixedgrass and shortgrass prairie in western North America" (Ostlie et al. 1996, p66). It was the second most significant herbivore on the Plains. Habitat changes and extensive eradication efforts have reduced numbers about 90 to $98 \%$ (Nebraska Game \& Parks Commission 1995; Ostlie et al. 1996, p66). Areas of short and mid-grass rangeland overgrazed by livestock are the prairie dog's preferred habitats. The prairie dog faces many natural predators, including the Black-footed Ferret.

Many wildlife species are closely associated with prairie dogs colonies (e.g., American Badgers, Golden Eagles, Prairie Falcons, Mountain Plovers, Ferruginous Hawks, Cottontails, Burrowing Owls, Black-footed Ferrets, Swift Foxes). Partly due to the efforts to eradicate prairie dogs, several of these associated species have also diminished in numbers. "Prairie dogs are a keystone species and their decline is threatening vertebrate biodiversity in the prairie ecosystem" (Ostlie et al. 1996, p79).

The prairie dog is not always compatible with agricultural interests. By eating and clipping vegetation, it may compete with livestock. Recent research however shows there is "minimal (4 to 7\%) competition between livestock and prairie dogs" (Ostlie et al. 1996, p66). The economic impact of the prairie dog on rangeland is difficult to assess and depends on several factors. These include the density of prairie dogs, the amount of rainfall, the presence of livestock, and the condition of rangeland in the surrounding area. Most landowners are tolerant of small numbers of prairie dogs, but are concerned about large colonies or expanding populations. Prairie dog numbers fluctuate considerably in many areas, primarily due to extensive control measures. Where they are not controlled, their numbers in recent years seem healthy and even increasing (Nebraska Game \& Parks Commission 1995).

\section{Ord's Kangaroo Rat (vulnerable)}

The Ord's Kangaroo Rat is a medium-size, nocturnal rodent native to the United States and Mexico. Small localized populations occur in the sandhills of southeastern Alberta and southwestern Saskatchewan. In Alberta, this species occurs "from south of the Red Deer River to just north of Hilda, and from the Saskatchewan border to the military reserve at Suffield" (Smith 1993, p102).

Kangaroo rats are most often found in grassland and scrubland habitats with sparse vegetation and sandy soil. "Maintenance of this rare species depends on the availability and management of sand dunes and loose sand areas suitable for burrows" (AEP 1996, p21). In 1995, COSEWIC recognized Ord's Kangaroo Rat as vulnerable. This designation was given because, in Canada, kangaroo rats occur "only in restricted areas at the northern edge of their range, and in geographic isolation from other members of the species" (Gummer 1995, p5). The populations in Alberta are considered "stable but very localized in sandhill and sand plain habitats" (AEP 1996, p21). Ord's Kangaroo Rat is on the BLUE LIST for Alberta as a species for which current knowledge suggests it may be at risk (ibid.). 


\section{Caspian Tern (vulnerable)}

Caspian Terns frequent large lakes rich in small fish. They usually nest on small, isolated islands with little or no vegetation. According to Semenchuk (1992, p138), this species has "a worldwide, but highly disjunct breeding distribution." In Canada, most of the population exists in a few large colonies in Manitoba and Ontario. There are 19 known breeding sites in the Prairie Provinces (Poston et al. 1990). In Alberta, two small colonies are known, at Lake Newell in the south, and at Egg Island in the northeast part of the province. Sightings have been reported at other locations.

The tern is "a rare breeder in Alberta, with about 50 pairs" (Semenchuk 1992, p138). This represents about $1 \%$ of the total Canadian population. Historical data suggest that there has been no reduction in the breeding range of this species in Canada, but there have been population fluctuations in some areas. A decline from 2250 nests or more in 1970 to less than 1400 nests in 1979 was attributed, in part, to the abandonment of one large colony because of road construction (Poston et al. 1990, p93). This species is "sensitive to water pollution, changes in water levels in nesting habitat, and disturbance of the nest site, particularly in the early stages of breeding" (Semenchuk 1992). In Alberta, the Caspian Tern is on the Yellow B LIST as a "very rare" species that is "locally distributed" (AEP 1996, p26).

\section{Ferruginous Hawk (vulnerable)}

This species now inhabits about $48 \%$ of its former range (Microsoft Internet Explorer 1996). In the early 1900s, it nested throughout south and central Alberta, as far north as Edmonton. By 1987, nesting birds were found no further north than Coronation. "Ferruginous Hawks have retracted their range in Alberta about 40\%" (Schmutz et al. 1994, p17) and populations declined more than $50 \%$ where the land had been cultivated (Schmutz 1990).

This species is a specialized hunter of Pocket Gophers, ground squirrels and hares. "Ferruginous Hawks require uncultivated, open grassland with abundant ground squirrels, which comprise $80 \%$ of their diet" (RENEW 1996, p7). Without sufficient food, the hawks will not establish a nest. Loss of prairie habitat to cultivation, settlement and resource exploration has reduced prey abundance and availability of nesting sites. Fire suppression has allowed invasion by woody plants, further reducing prey habitat. This species is easily disturbed by human activity, particularly during the nesting period. These factors have led to serious declines in numbers of Ferruginous Hawks (Schmutz, 1987; Trottier 1992, p19).

However, this species represents a minor recovery success story (RENEW 1996, p7). Populations in southeastern Alberta are estimated to have increased from 1082 pairs in 1982 to 1772 pairs in 1987 (Poston et al. 1990). AEP (1996) estimates a current population of 1400 to 1700 pairs, over half the Canadian population (Microsoft Internet Explorer 1996). This increase is, in part, due to successful nest site restoration programs (e.g., protection of nest trees and erection of nesting platforms). Another important factor has been the cooperation of landowners who are increasingly aware of the essential role these predators play in the prairie ecosystem. The Ferruginous Hawk was listed as a species at risk (RED LIST) in 1991, but based on its 
population recovery, has been moved to the BLUE LIST (may be at risk). "If [the] current recovery of [the] breeding population continues and key nesting and feeding habitats can be secured, the species can be considered for change to a YELLOw LIST" (AEP 1996, p20).

\section{Long-billed Curlew (vulnerable)}

For nesting, curlews require large tracts of open grassland with low vegetative cover and no visual barriers. Maximum breeding densities occur in moderately grazed grasslands on sandy loam soils. This species was once common over most of the prairie regions of southern Canada. Since the late 1800 s, the Long-billed Curlew has undergone considerable reductions in numbers and breeding range, mainly because of over-hunting and loss of its grassland habitat. It is "thought to be declining throughout its Canadian range" (AEP 1996). It is now "found only in isolated populations in south and central British Columbia, southern Alberta, and southwestern Saskatchewan" (Semenchuk 1992, p125). In Alberta, the Long-billed Curlew is on the BLUE LIST as a species that may be at risk. Curlew numbers are low and possibly declining (Semenchuk 1992, p125; AEP 1996, p20) but the available data are "insufficient to allow effective management" (AEP 1996, p20).

\section{Short-eared Owl (vulnerable)}

This owl prefers to breed in relatively open country such as grassland, grassy or bushy meadows, marshland, pastures, stubble fields, crop lands, and previously forested areas that have been cleared. A combination of areas of suitable cover, with adjacent hunting areas containing an abundance of small mammals, is a dominant factor in selecting breeding habitat. It "relies on maintenance of edges of larger wetland habitats" (AEP 1996, p21).

According to Semenchuk (1992, p155), this owl breeds in the south and central parts of the province. The northern limit of breeding is at Peace River, Lesser Slave Lake, and Cold Lake (ibid.). Currently, it is a fairly common species in the Grassland and Parkland Natural Regions of the province ( $\mathrm{ibid}$.), but the "irruptive nature of populations make population trend assessments extremely difficult" (AEP 1996, p21). This owl was on the Audubon Society's Blue List of declining species from 1976 to 1986 (Semenchuk 1992, p155) and is now listed by COSEWIC as a vulnerable species (COSEWIC 1996). It is on the Alberta BLUE LIST as a species that may be at risk, but the "causes of population decline are unknown" (AEP 1996, p21).

\section{Short-horned Lizard (vulnerable)}

In North America, the Short-horned Lizard is found from the western Dakotas to northeastern Montana and adjacent Canada, and south to eastern Colorado and extreme northeastern Utah. In Wyoming and Colorado, the Short-horned Lizard is no longer present in several large areas. The species is locally common in the semi-arid short grass plains of the extreme western portion of Nebraska (NPSC 1996). In Canada, this species is localized and rare, being restricted to southwestern Saskatchewan and southeastern Alberta. "Small scattered populations occur along the Milk River valley and the South Saskatchewan River valley, and at a few sites between" (Wershler and Wallis 1986, p18-19). 
Short-horned Lizards frequent shortgrass prairie, sagebrush, open rocky or sandy plains, and open pinon-juniper, pine-spruce, and spruce-fir forests. Typically, they inhabit hot dry or semiarid regions, such as the shortgrass plains in rough terrain. The soils may be stony, sandy, or firm, but usually some fine loose soil is present. They are often found under or around sagebrush plants (NPSC 1996). In Alberta, this species typically occupies coulee edges, where badlands merge with grassland. It has also been found in yucca stands on badland slopes. "The Lost River populations inhabit relatively undisturbed south or southwest-facing grassland/badland ecotones" (Wershler and Wallis 1986, p18-19).

Loss of habitat and habitat fragmentation due to cropping, intensive grazing, and petroleum and natural gas development have affected this species. Aerial spraying of insecticides also may have reduced insect populations, the main diet of Eastern Short-horned Lizards (NPSC 1996). In Alberta, the Short-horned Lizard is on its BLUE LIST as a species that may be at risk. The population status and trend are unknown and require further investigation(AEP 1996, p2).

\section{Hare-footed locoweed - Oxytropis lagopus (vulnerable)}

The following is taken from Smith (1994). Hare-footed locoweed is endemic to the Rocky Mountains - it has a very narrow distribution, and is found only from Wyoming to western Montana and Idaho, to southern Alberta. In Montana, it is considered rare. In Canada, it is known only from southwestern Alberta. It is restricted to an area near the Montana border, south of Cardston. Populations have been found between Whiskey Gap in the west, to the vicinity of Shanks Lake in the east, and north to the Ross Lake area. "An estimated total of 10 to 20 thousand specimens is located within the restricted Alberta range" (pg. i).

This species "is found only on the unglaciated, gravelly soils of the Milk River Ridge, particularly, the areas surrounding the North Milk River ... It is known from only eight closely distributed locations, all in the Foothills Fescue Subregion" (pg. i). This plant grows mostly "within a $10 \mathrm{~m}$ wide strip along the upper slopes or plateau rims of steep ridges" (pg. i). "Gravel extraction poses the primary threat to the continued success of the species in Alberta, because of the abundance of gravel on the preferred sites. At present, no sites are in immediate danger" (pg. ii). Although some of the original habitat may have been cultivated, the remaining sites are steep and further cultivation is unlikely.

\section{Smooth narrow-leaved goosefoot - Chenopodium subglabrum (vulnerable)}

The following is taken from Smith and Bradley (1990c). Smooth narrow-leaved goosefoot is found from south-eastern Alberta to south-western Manitoba in Canada, and south to Nevada, Utah, Colorado and Kansas in the United States. In Alberta, the species is widely scattered at several sites in the southern mixed grassland. Only at one site (i.e., Turin) does it occur with any frequency.

Populations are "generally found on south- or west-facing, actively eroding slopes at the edge of stabilizing sand" (p7). They sometimes grow in dune slacks. "Populations are highest in areas of finer and more compacted sand" (p7). Smooth goosefoot also grows in alkali soils. The total 
Alberta population is estimated to be under 100 individuals. The main limiting factor is its narrow habitat preference for actively eroding sites within sand dune fields. This type of habitat appears to be declining, due in part to fire control.

\section{Soapweed - Yucca glauca (vulnerable)}

Soapweed, also called "soapweed yucca", "beargrass", and "Spanish bayonet", grows throughout much of the Great Plains, from Texas and Arizona, northward to southeastern Alberta, Montana and the Dakotas. It extends eastward into portions of Kansas, Nebraska, Iowa, and Missouri (FEIS 1996, NPSC 1996). Soapweed is a common constituent of many plains grassland, drier forest-grassland and prairie communities. It is a climax dominant on sandy range sites and grasslands of Montana, east of the Continental Divide (FEIS 1996).

Soapweed grows on dry, rocky outcrops, ridges, dry prairie slopes, badlands, lower mountains, prairies, and plains. It is often found thinly scattered in rolling grasslands or in open coniferous woodlands, but also occurs in dense stands in some areas. This yucca grows well on a variety of soils including coarse gravel, sand or porous loam. Growth is often best on compact sands and it is considered an indicator of sand (FEIS 1996). Light or moderate grazing pressure may favour yucca, but heavy grazing may be deleterious as cattle like the fleshy flowers and young seed pods (NPSC 1996).

An interesting and well-studied aspect of yucca ecology is the symbiotic relationship between yuccas and their pollinators. Soapweed relies solely on the Yucca Moth (Tegeticula yuccasella) for pollination. Seed production is thus totally dependent on the availability of this pollinator that, in the larval stage, feeds on some of the seeds (generally around 7\%). In some years, less than $1 \%$ of the flowering stalks set fruit due to lack of pollinators, or poor weather conditions (FEIS 1996).

In Canada, soapweed reaches the northwestern limits of its range. There are only two known populations, both occur in Alberta in the Milk River/Lost River area. Here it is locally abundant (ANHIC 1996), growing on coulee crests (Fairbarns 1984). The total population is estimated at over 50,500 individuals ( $i b i d$.). A third population, east of the town of Fox Creek in Saskatchewan, is generally considered introduced. Due to the limited number of populations, the species is considered vulnerable in Canada, but does not seem under any immediate threat (ibid.).

\section{St. Mary River Shorthead Sculpin — Cottus sp. (under review)}

The following is quoted from the 1996 State of the Environment Report for aquatic ecosystems in Alberta (Alberta Environmental Protection 1996a):

"Sculpins (Cottus species) are small bottom-dwelling fish that live amongst stones and eat aquatic insect larvae. Several species occur in the Milk River and also in a few other locations within the province." 
"There has been some taxonomical uncertainty regarding the species. The species referred to here as the 'St. Mary Sculpin' was not known to occur in Alberta until 1988 when it was identified by W. Roberts. It is considered a threatened species by COSEWIC." [Note: The species is not shown on the 1996 COSEWIC lists but has been ranked by the Alberta Natural Heritage Information Center as an S1T species for the province]. "The largest specimen found in the province measures $10.8 \mathrm{~cm}$."

"To date, the St. Mary Sculpin has been found in two river reaches in Alberta: about $220 \mathrm{~km}$ of stream in the upper and middle reaches of the Milk River and about $80 \mathrm{~km}$ of stream in the upper St. Mary River. A population in the Milk River upstream of the confluence with the North Milk River has apparently disappeared, probably due to low or absent flows in some years. However, the range has extended eastward in the main stream. Thus, the population appears stable, although vulnerable to the low flows."

According to Roberts (1989), "sculpins are indicators of stream quality; they require clean water and clean substrate in order to prosper."

Prairie habitats also support a number of other notable species. The next chapter focuses briefly on some of these species. 


\section{Chapter 1.7 Notable Prairie Species and Species Groups}

The Alberta grasslands provide essential habitat for many species. The following section focuses on those species groups for which the grasslands are particularly important, such as migrating shorebirds and both nesting and staging waterfowl. In addition, there are a number of species that rely on prairie habitats that have been identified in "The Status of Alberta Wildlife" (AEP 1996) as "at risk" (species on the RED and BLUE lists). A brief discussion on each of these is included. Also included is a discussion of species on that report's YeLLOW A and YeLLOW в lists. Although not considered at risk, these species are generally those considered sensitive and vulnerable to changes to the environment. Information on the status of several of the species found in the grassland is limited. These are on the STATUS UNDETERMINED list, and are also discussed below. Species on the GREEN list are not discussed. They are not considered at risk and have secure habitats and stable populations.

\section{Waterfowl}

The three prairie provinces produce about $60 \%$ of the waterfowl on the continent (DU \& ENR, n.d.). "The Grassland and Parkland Ecoregions provide the most significant complex of breeding habitat in the continent" (Poston et al. 1990, p30). Most of the production occurs in pothole complexes, small ponds a few acres in size, scattered across the prairies. Historically, Alberta has had some of the best waterfowl habitat and some of the highest waterfowl densities and productivity levels in North America; up to $40 \%$ of the total waterfowl production in the three prairie provinces (DU \& ENR, n.d.).

Over $25 \%$ of both Mallard and Pintail and more than $20 \%$ of all ducks normally surveyed in North America are found in Alberta. Alberta's prairie wetlands also provide important breeding habitat for Canada Geese (AHJV 1989, p3). Major production areas for waterfowl in Alberta's prairie include the Milk River Ridge Complex, the Pakowki/Central Meltwater Complex, the Cypress Complex, the Eastern Plains, the Irrigation Core and the Foothills Corridor (AHJV 1989, p3). The Canadian Wildlife Service rates the Rumsey Upland as nationally important for breeding ducks, and the Deadhorse Lake Upland, Neutral Upland and Monitor Hills as regionally important (Poston et al. 1990). Table 16 lists some of the high priority habitat areas for waterfowl in Alberta.

In addition to their importance as breeding areas, Alberta's wetlands are significant, both nationally and internationally, as moulting, stopover and staging areas for large numbers of migrating waterfowl, primarily from the Pacific and Central flyways. Northern-nesting species of geese, for example, rely primarily on parkland and prairie habitats for staging during the fall and spring migration (Poston et al. 1990). An estimated one million Canada geese stage in the southern prairies, as does "most of the world's Lesser Snow Goose population" (ibid., p50). There has been a shift in the use of staging areas in the last 10 years caused perhaps by "changes in population size, weather and habitat conditions" (ibid., p55). 
Table 16. High priority prairie habitat areas for waterfowl in Alberta (after Poston et al. 1990)

\begin{tabular}{|l|l|l|}
\hline Type of Habitat & \multicolumn{1}{|c|}{ Nationally Important Sites } & \multicolumn{1}{c|}{ Regionally Important Sites } \\
\hline Duck moulting habitats & & Pakowki Lake, San Francisco Lakes \\
\hline Duck staging habitats & Many Island Lake & $\begin{array}{l}\text { Namaka Lake, Pakowki Lake, 40-Mile Coulee, Yellow } \\
\text { Lake, Louisiana Lakes, Frank Lake }\end{array}$ \\
\hline Goose breeding habitats & & $\begin{array}{l}\text { Cavan Lake, Murray Lake, Fincastle Lake, Grassy } \\
\text { Lake, Taber Lake, Milk River Ridge Reservoir, Keho } \\
\text { Lake, Hays Reservoir, Scope Reservoir, Cowoki Lake, } \\
\text { Kininvie Flats, Little Bow Lake Reservoir, Bow } \\
\text { River/Calgary-Hays, St. Mary Reservoir }\end{array}$ \\
& & $\begin{array}{l}\text { 40-Mile Coulee, Tyrrell Lake, Travers Reservoir, Red } \\
\text { Deer River (Sandy Point to Saskatchewan border), } \\
\text { Birkshire Reservoir, Brent Lake, Coleman Lake, } \\
\text { Ensleigh Lake, Antelope Lake, Grays Lake, Oldman } \\
\text { Lake, Wiste Lake, Dowling Lake, Farrell Lake, } \\
\text { Handhills Lake, Little Fish Lake, Gough Lake, Lanes } \\
\text { Gake staging habitats }\end{array}$ \\
& $\begin{array}{l}\text { Plover Lake, Grassy Island Lake, } \\
\text { Fitzgerald Lake, Kirkpatrick } \\
\text { Lake, Chain Lakes, Sullivan Lake }\end{array}$ \\
\cline { 2 - 3 } & & \\
\hline
\end{tabular}

Larger marshes and lakes with stable water levels provide abundant food, adequate cover, isolation, and resting sites and are preferred areas for staging and moulting. Declines in natural wetlands along these migration corridors can result in a greater concentration of waterfowl on the remaining areas. This can result in "more rapid depletion of food sources as well as posing potentially higher mortality risks from disease and other causal agents" (Nietfeld et al. 1985).

Wetland habitats have been impacted or lost thereby "decreasing the habitat available for moulting, staging and migrant waterfowl" (ibid.). Losses of wetland habitats, combined with losses of native grasslands, have led to considerable declines in some waterfowl and other wetland-dependent species. The 1980s drought increased pressure on farmers to convert wetlands into cultivated fields. The dry conditions encouraged the ploughing of critical small wetlands. Changes in agricultural practices such as increased application of pesticides and fertilizers, aerial spraying and fencerow-to-fencerow farming has also negatively affected wildlife. Policies adopted by the Canadian government in the mid-1970s (e.g., encouraging agricultural expansion) also were implicated in reducing the amount of wildlife habitat. These factors in concert with a poor farm economy have forced prairie farmers in Canada to expand their operations, often into areas once considered "marginal" such as remnant native areas and hilly sections. Many wetlands and uplands used by wildlife as recently as the 1970s are no longer present (Nelson 1989). Important waterfowl areas such as small wetlands were some of the habitats most impacted (ibid.). "The very future of the waterfowl resource is being threatened by the expansion and intensification of agriculture" (AHJV 1989, p5).

Since approximately $95 \%$ of wetland habitats are associated with privately-owned land (DU \& ENR, n.d.), "the conservation and wise management of those and other remaining habitats is crucial to ensuring the future survival of wetland species" (Wetlands for the Americas, n.d.). 
Since the 1970s, there has been a progressive decline in populations of three common duck species - Mallard, Pintail, and Blue-winged Teal (Nelson 1989). For example, over $50 \%$ of the continent's population of Pintails is raised in the Canadian prairies, yet their numbers are down more than $80 \%$ from the 1950 s (PHJV 1993). The Alberta prairie "traditionally has contained the highest density and numbers of breeding Northern Pintails on the continent" (PHJV 1991, p3). During the 1980s, some duck populations declined to the lowest levels recorded, partly due to the combination of widespread drought and intensive agricultural practices.

The 1992 May Waterfowl Breeding Population Survey recorded a southern Alberta Mallard population that was $39.7 \%$ below the long term average (Turner and Pryor 1992, p8).

Waterfowl breeding surveys conducted in southern Alberta in May of 1995 showed a 35\% decrease in total dabbling ducks below the 1955-1994 mean (Bredy 1995, p5). The Canadian Wildlife Service concluded that "without intensive conservation management on private and public lands, the likelihood of these populations recovering to former abundance is minimal" (Environment Canada 1986b as cited in Usher and Scarth 1990).

Recent efforts through the North American Waterfowl Management Plan, however, are yielding positive results and waterfowl numbers appear to be improving (NAWMP 1996).

None of the waterfowl species that migrate through or rely on the prairies for breeding habitat are considered at risk (AEP 1996). The one exception to this is the Trumpeter Swan. Although the main breeding population in Canada is now in the Grande Prairie area, there were two probable nesting locations reported for the grasslands in the Breeding Bird Atlas (Semenchuk 1992). Historically, Trumpeter Swans were widespread throughout North America. By the 1930 s, their numbers and range were severely reduced, largely due to overhunting. In 1933, the known population was down to 66 birds, although this did not count those nesting in the Grande Prairie area or a population later discovered in Alaska (Shandruk 1987, p179). COSEWIC designated the Trumpeter Swan as rare in 1978. The status was changed to "vulnerable" in 1990 and in 1996 to "not at risk". The Alberta population has been increasing at about 7\% per year (Semenchuk 1992). The species, however, remains on the BLUE LIST (may be at risk), due largely to concerns regarding a "critical shortage of key winter habitat" (AEP 1996, p21).

\section{Other Wetland-Dependent Birds}

Prairie wetlands provide important habitat for a number of other wetland-dependant birds, including many colonial-nesting species such as pelicans, grebes and herons. Prairie wetlands are extremely important to these species. Approximately $60 \%$ of the American White Pelican population, $20 \%$ to $50 \%$ of various grebe species, and $15 \%$ of the continent's Great Blue Heron population nest in the prairie wetland habitats of southern Canada (PHJV 1993, p6). These habitats include areas such as lake islands, wetland emergents and vegetation communities adjacent to rivers and streams. Five species associated with prairie wetlands are included on the YELLOW A LIST in the Status of Alberta Wildlife (AEP 1996), as follows: 
American Bittern: Found in small numbers throughout North America, Finch (1992) considered the American Bittern a species of concern due to significant population declines in the United States. The declines were linked to agricultural conversion, accidental pesticide poisoning and habitat loss. One study suggested that the bittern is found only in wetlands with suitable habitat larger than 11 hectares (Brown and Dinsmore 1986, as cited in Finch 1992). The population status in Alberta is unknown, but declines are suspected. This solitary nesting bird "relies on permanent to semi-permanent wetlands with well-developed emergent vegetation. Drainage, consolidation and cultivation of these marshes is a continuing threat" (AEP 1996, p22).

Black Tern: This colonial species is "found throughout temperate North America and Eurasia" (Finch 1992). It "relies on [the] maintenance of larger marsh/wetland habitats" (AEP 1996, p22). Brown and Dinsmore (1986), as cited in Finch (1992), found that Black Terns were most common on wetlands larger than 20 hectares. The population status is unknown, but declines have been documented "in Saskatchewan, and over large parts of [the] North American breeding range." Semenchuk (1992) concludes that habitat loss is probably the main cause of declines, which were among the highest for any species counted in the Breeding Bird Survey (Finch 1992).

Horned Grebe: This grebe is primarily a western species, breeding from "central Alaska and northwestern Canada south to eastern Washington and east to Wisconsin" (Campbell et al. 1990). In Alberta, it breeds throughout the province, with populations concentrated in the southern boreal, parkland and grassland areas (Semenchuk 1992). The Horned Grebe is primarily a solitary nester but occasionally nests in small loose colonies. It prefers small wetlands for nesting, usually less than 5 hectares in size, with extensive marshy vegetation (ibid.). The population is declining throughout its Alberta range. "Breeding Bird Survey data show [a] sharp decline in the last two decades." This appears to be related to the loss of small wetlands due to drought (AEP 1996, p22).

Pied-billed Grebe: This solitary-nesting grebe is one of the most common in North America (Semenchuk 1992), breeding from "central Canada south throughout most of North, Central and South America" (Campbell et al. 1990). It breeds throughout Alberta, with most of the population being found in the parkland and southern boreal areas, and significant numbers in the grasslands (Semenchuk 1992). Like the Horned Grebe, this species also prefers small wetlands with extensive marshy vegetation, but it is occasionally found in other wetland habitats (Semenchuk 1992). The population is declining throughout its Alberta range. "Breeding Bird Survey data from Alberta show declining numbers over the last two decades." This appears to be related to the loss of small wetlands due to drought (AEP 1996, p23).

Red-necked Grebe: This species breeds "from western Alaska across central Canada to Ontario, south to Washington and southern Wisconsin" (Campbell et al. 1990). It is primarily a solitary nester. About half of Canada's population of Red-necked Grebes breed in Alberta. Although the main population is found in the parkland and southern boreal parts of the province, significant numbers are found in the grassland (Semenchuk 1992). This is probably Alberta's most common grebe, breeding in extensive marshy vegetation. Populations may be declining (AEP 1996) as a result of "pothole drainage, land clearing, environmental contamination and human recreational activities on lakes" (Semenchuk 1992). 
Ten species found in prairie habitats are on the YELLOW в LIST for Alberta. One, the Caspian Tern, is listed by COSEWIC as vulnerable and has been discussed earlier. The remaining species are as follows:

American White Pelican: This species "breeds locally from southwestern Canada south to southern California, northern Utah, southern Montana and South Dakota" (Godfrey 1986). Although colonies are occasionally found on deep lakes or rivers, this pelican prefers shallow lakes with a good fish population (Semenchuk 1992). Nesting colonies are usually located on low, protected flat islands. Semenchuk (1992) summarized the population trends of this species as follows. Their populations declined in Canada until the 1970s, and in 1978 COSEWIC listed the pelican as threatened. Under protection, their populations rebounded from less than 16,000 breeding pairs in the mid-1970s to 50,000 in the 1980's. The species was then removed from the COSEWIC list in 1987. In Alberta, AEP (1996) estimates there are about 1000 nesting pairs scattered throughout the eastern half of the province. Their numbers are increasing, possibly due to birds moving in because of drought elsewhere. The number of active colonies, however, are decreasing and there is concern of a possible disease risk (ibid., p24.). Pelicans are vulnerable to pesticides and disturbances at their nesting site.

Black-crowned Night Heron: This is a small, widely distributed heron. In North America, it breeds "throughout much of the United States and central, southern and southeastern Canada" (Campbell et al. 1990). In Alberta, it nests primarily in the Grassland and Parkland Natural Regions (Semenchuk 1992). This night heron is a "colonial species, reliant on marsh habitat" (AEP 1996). Population trends are "downward in eastern Canada" (Desgranges and Laporte 1979 as cited in Poston et al. 1990, p73). Numbers, however, have increased in Alberta (AEP 1996). Semenchuk (1992) suggests that this species is "particularly susceptible to land clearing, drainage and human disturbance."

Clark's Grebe: This is a "poorly known" species that "breeds in very small numbers from Washington and the southern Canadian prairie provinces south to Mexico" (Campbell et al. 1990, p374). This grebe is similar to the Western Grebe and nests in similar habitats - larger lakes with abundant fish and marshy vegetation (Semenchuk 1992). For successful breeding, it requires stable water levels and minimal human disturbance (ibid.). It has a localized distribution in Alberta, with "less than 20 breeding pairs " (AEP 1996, p26). During the Breeding Bird Atlas Project, only one breeding location was found - at Crow Indian Lake in the south-central Alberta (Semenchuk 1992).

Double-crested Cormorant: This species is widespread, breeding from "southwestern Alaska, central Alberta, James Bay and Newfoundland south to Mexico and the Bahamas (Godfrey 1986). Although locally distributed in Alberta, the population is increasing. Once designated as endangered in Alberta, increasing populations allowed it to be removed from that list (AEP 1996, p26). Alberta colonies are generally located in the south and central portions of the province (Semenchuk 1992). They nest on flat, low-lying islands within large lakes having a good fish supply. Like pelicans, cormorants are vulnerable to disturbance at their nesting sites. 
Forster's Tern: This tern breeds from southeastern British Columbia and the prairie provinces south through the eastern parts of Washington and Oregon to California, Colorado and Iowa, and up through to Wisconsin. There is also an Atlantic coastal population in the United States (Campbell et al. 1990a). In Alberta, the main population is in the parkland and southern boreal forest, but there are also some colonies in the prairies. This tern "prefers the deeper portions of large cattail marshes" for nesting (Semenchuk 1992, p140). It is an uncommon species that breeds only locally and may be of concern due to loss of marsh habitat (AEP 1996; Semenchuk 1992).

Great Blue Heron: This heron is wide-ranging, breeding throughout much of the northern and central Americas south to the Galapagos. In Alberta, they nest mainly in the central and southern areas of the province (Semenchuk 1992). Nesting is usually in trees near water and it feeds in the shallow waters of rivers, streams, wetlands and ditches. The Great Blue Heron is "suspected to be in decline throughout much of its range" in Canada (Poston et al. 1990, p72). In Alberta, however, "known colony numbers doubled between 1967 and 1980" (Brechtel 1981 as cited in Poston et al. 1990). The Alberta population is considered stable, with approximately 75 colonies and 1500 breeding pairs (AEP 1996). "Management of key habitats and protection from human disturbance is essential" (ibid., p26).

Marsh Wren: This bird commonly nests in cattails. It breeds across southern Canada south to California, New Mexico, Texas and Florida (Godfrey 1986). In Alberta, populations are concentrated in the parkland, but it also occurs in the grasslands. Its population status is unknown, but drought conditions over the past 10 years combined with impacts on prairie wetlands have eliminated some breeding areas (ibid., p27).

Western Grebe: This grebe breeds in western North America from southern British Columbia and the Canadian prairie provinces south to Mexico (Godfrey 1986). In Alberta, this species breeds as far north as Slave Lake. A significant portion of the population is also found in prairie habitats. They are "colonial nesters, usually found on medium to large lakes" (Semenchuk 1992, p41). They nest in emergent vegetation and although local and uncommon, populations in Alberta are believed to be stable (AEP 1996, p28). Disturbances such as "industrial developments, recreational activities and unstable water levels" are believed to cause this grebe to abandon otherwise suitable nesting habitat (Campbell et al. 1990).

White-faced Ibis: This is a southern species that mainly breeds in the Great Basin area, nesting in loose colonies. It appears to be expanding its range northward. It was first documented in Alberta in 1974, and has been regularly observed since (Semenchuk 1992, p41). It "breeds in marshes of larger lakes and forages on mudflats, in shallow marshes, sloughs, flooded pastures, meadows, and in irrigated fields" (ibid.). It is very locally distributed in Alberta with under 20 breeding pairs (AEP 1996, p28). It is considered a sensitive species in the United States and is "vulnerable to marsh drainage, human disturbance" and pesticide contamination within its winter range (Semenchuk 1992, p50).

One wetland dependant bird, the Virginia Rail, is on the status undetermined list. This is a secretive bird that nests in emergent vegetation. 
Many of the above species are colonial nesting birds. According to Poston et al. (1990), some of the nationally $(\mathrm{N})$ and regionally $(\mathrm{R})$ important breeding sites for colonial waterbirds in Alberta's prairie wetlands include: Pakowki Lake (Black-crowned Night Heron, R), Murray Lake (Great Blue Heron, R; Ring-billed Gull, R), Grassy Lake (Eared Grebe, N), Stirling Lake (Ring-billed Gull, R), Keho Lake (Ring-billed Gull, R; California Gull, N), Lake Newell (Double-crested Cormorant, N), Dowling Lake (Ring-billed Gull, R; California Gull, R), St. Mary Reservoir (Ring-billed Gull, R; California Gull, N), Janet Slough (Eared Grebe, R) and Irricana Reservoir (Ring-billed Gull, R).

The prairie wetlands are also important during migration for many species. For example, up to $75 \%$ of the Franklin's Gull population and $95 \%$ of all Sandhill Cranes stage on or near prairie wetlands (PHJV 1993, p6). Poston et al. (1990) also list some of the nationally (N) and regionally $(\mathrm{R})$ important staging areas for colonial waterbirds in Alberta's prairie wetlands. These include: Lake Newell (Western Grebe, R; Double-crested Cormorant, N), McGregor Lake (American White Pelican, N), Namaka Lake (Western Grebe, N), Irricana Reservoir (California Gull, N) and Shooting Lake (Black-crowned Night Heron, R), (ibid.).

Colonial-nesting species and other wetland-dependant birds have been affected by habitat loss and degradation through land clearing, drainage and human disturbance. In addition, "toxic wastes and pesticides pose serious threats to these species because of their diets of fish and/or aquatic invertebrates" (Poston et al. 1990, p66). Colonial nesting species are "particularly vulnerable to site-specific disturbances and habitat changes" (ibid., p66).

\section{Shorebirds}

The Canadian prairie region is an important migration staging area for Arctic-nesting shorebirds (Poston et al. 1990). About $80 \%$ of Lesser Golden Plovers, $75 \%$ of Baird's Sandpipers, $50 \%$ of Hudsonian Godwits, and $35 \%$ of White-rumped Sandpipers stage in Canada's southern prairies during migration (PHJV 1993, p6). Short-billed Dowitchers and Sanderlings also frequent the prairies during migration (Salt and Salt 1976).

Shorebird migrations have evolved over thousands of years. "Many birds follow the same routes and use the same wetland areas along the way each year, making it difficult for them to respond to dramatic and rapid changes in the landscape" (Wetlands for the Americas, n.d.). "The occurrence of mud flats and shallow water habitats is critical to refuelling efforts of small shorebirds. These habitats are perhaps some of the most endangered habitats in the continent because of the rapid loss of wetlands due to agricultural conversion and extensive alteration of hydrologic processes" (Ostlie et al. 1996, p81).

In addition to being an important migration route, the prairies provide crucial breeding habitat for several species of shorebirds. Eighty percent of the continent's Marbled Godwits, $40 \%$ of the Willets, and $20 \%$ of all American Avocets and Wilson's Phalaropes nest on the prairies (PHJV 1995, p6). The Long-billed Curlew (BLUE-LISTED by Alberta, listed as vulnerable by COSEWIC), the Mountain Plover (YELLOW B-LISTED by Alberta, listed as endangered by 
COSEWIC) and the Piping Plover (RED-LISTED by Alberta, listed as endangered by COSEWIC), have been discussed previously in Chapter 1.6. Three additional shorebird species are on Alberta's YeLLOW B LIST, as discussed below.

American Avocet: The avocet is primarily a western species, breeding in southeastern British Columbia through the southern prairies and southwest Ontario south to the southwestern United States (Campbell et al. 1990a). In Alberta, it is found mainly in the parkland and grassland areas of the province. It "favours the shallow muddy borders of saline or alkaline lakes or sloughs" (Semenchuk 1992). Although locally abundant, "drought and the degradation of prairie wetlands ... have further restricted the distribution of this species" (AEP 1996).

Black-necked Stilt: This species favours "shallow and brackish pools, marshes and lakes, especially where there are extensive areas of mudflats" (Semenchuk 1992, p117). It breeds locally north from south America through to southern Washington (Campbell et al. 1990a). Here it is at the northern edge of its range, and southern Alberta is the only place it breeds in Canada (Semenchuk 1992). Few populations and localized distribution make it vulnerable to habitat loss (AEP 1996).

Willet: This species "breeds in the prairie regions of Canada, the northwestern United States, and on the Atlantic coast from Nova Scotia to northern Mexico" (Campbell et al. 1990a). It frequents "moist and wet meadows and the grassy edges of prairie sloughs and lakes" (Semenchuk 1992). Although the Breeding Bird Atlas surveys found it to be common in the Alberta prairies and parkland (ibid.), there is some evidence that populations may be declining (AEP 1996), possibly due to drought and wetland drainage, particularly in the prairies.

Wetland loss and degradation have affected shorebird populations (Howe, 1987). Howe et al. (1989), in their analysis of International Shorebird Survey data, found that Short-billed Dowitchers and Sanderlings experienced significant declines in their numbers between 1972 and 1983. Population declines for these species ranged between 46 and $80 \%$. Many shorebird species have suffered precipitous declines, some by as much as $80 \%$ in the last 25 years (Wetlands for the Americas, n.d.).

\section{Landbirds}

According to Partners in Flight - Canada (1996), landbird populations in both the United States and Canada have shown long-term declines over the last 30 years. This includes many neotropical migrant species. Declines in some forest edge and grassland species that winter in the United States have also been reported for Canada and the United States. The Greater Prairie Chicken is considered extirpated in Alberta and Canada and was discussed earlier. There are two species of landbirds found in the grasslands that are on the BLUE LIST for Alberta - Sage Grouse and Sprague's Pipit. They are discussed below.

Sage Grouse: This grouse is generally found in semi-arid grasslands, primarily in sagebrush (Artemisia cana) habitats. Their distribution is closely linked to that of sagebrush. They are 
found from central Washington, southern Alberta and Saskatchewan, and south to eastern California (Campbell et al. 1990a). Sage Grouse are limited in Canada to the extreme southeastern part of Alberta and the southwestern part of Saskatchewan and are at the northern edge of their range there (Sauer et al. 1996). The species has been extirpated from British Columbia and, although once widespread, "it is today a local resident throughout its range" (Campbell et al. 1990a, p458). Removal of sagebrush by cultivation or overgrazing can cause declines in Sage Grouse populations (Nietfeld et al. 1985). Cattle may compete with Sage Grouse for food, particularly when wintered on sagebrush ranges. Breeding Bird Survey data indicate that overall population trends for Sage Grouse are downward, with the greatest declines occurring in the United States, in parts of Montana, Wyoming and Nevada (Sauer et al. 1996). In Alberta, populations have undergone a "rapid decline" although the reasons for the decline are unknown (AEP 1996).

Sprague's Pipit: This species breeds from the prairies of Canada south to Montana, North Dakota and northwestern Minnesota (Godfrey 1986). In Alberta, it breeds in the grassland and parkland areas of the province. It seems to be intolerant of heavy grazing, but will use moderately grazed areas (Semenchuk 1992). It seems unable to use non-native habitats and so its potential range has been reduced (ibid.). Prescott and Wagner (1996) found Sprague's Pipit only on native prairie pastures. Breeding Bird Survey data have documented "dramatic population declines" (AEP 1996).

A number of grassland species are on the YeLLOW A LIST for Alberta. One, the Loggerhead Shrike, is listed by COSEWIC as threatened and was discussed earlier. The others are as follows:

Baird's Sparrow: This species "has a restricted breeding range, occurring only in the northern Great Plains" (Finch 1992). In Canada, it breeds in southern Alberta, southern Saskatchewan and southwest Manitoba. Historically, it was very abundant in the mixed grass and tall grass prairies. Now, it "probably exists at less than 5\% of its former levels" (De Smet and Miller 1989). Although Breeding Bird surveys indicate significant continent-wide declines from 1966 to 1985 (Finch 1992), recent work suggests that there is "insufficient evidence" from productivity data "to conclude whether the total population is stable, increasing or decreasing" (Goossen and Dale 1996, p10).

This species prefers nesting sites with tall, dense grasses and shrubs. Wershler (1990) noted that "fescue grassland is the principal habitat type in Alberta currently used by Baird's Sparrows, followed by mixed grassland, dry lakes and ponds, and riparian meadows." It usually does not breed in grasslands that have been moderately to heavily grazed because of its preferences for tall, dense grasses. Loss of quality nesting habitat as a result of "intensive agriculture, heavy grazing, and other high impact land use activities appear to be major limiting factors affecting Baird's Sparrows" (Goossen et al. 1993). It has been found that "land on which grazing is done on a rotational basis can support nearly ten times as many Baird's Sparrows as continuously grazed pasture" (RENEW 1996, p6). Although on the YELLOW A LIST, more information is required on the apparent population declines of this species to clarify its status (AEP 1996). 
Brown Thrasher: Brown Thrashers in Alberta are at the northwestern edge of a range that extends east to Quebec and Maine and south to Florida. They breed in the parkland, but the main Alberta population is in the Grassland Natural Region, where tall shrubbery in coulees is the preferred habitat. Although considered by Semenchuk (1992) to be relatively common in Alberta's grasslands, AEP (1996) concludes that the population status is unknown but may be declining. Based on this, the Brown Thrasher was placed on the YELLOW a LIST for Alberta.

Clay-colored Sparrow: This sparrow breeds west to the interior of British Columbia, north to the southern Mackenzie area, east to southern Ontario and south as far as northern Texas (Godfrey 1986). It is found throughout Alberta, but most commonly in the parklands and prairies (Semenchuk 1992). It prefers shrubby grasslands, shrubby openings in woodlands and shrublands adjacent to watercourses and wetlands. It nests near the ground in shrubs or small trees. Although a common bird in Alberta, it is on the Yellow A LIST. Populations were considered to be healthy and stable in 1991, but Breeding Bird Survey data show a declining population in recent years. Reasons for the recent population declines have not been documented (AEP 1996).

Sharp-tailed Grouse: This grouse is widespread, ranging from Alaska and across Canada as far east as Quebec and south to "eastern Oregon, northern Utah, Colorado, Minnesota and northern Michigan" (Godfrey 1986). It occupies a variety of habitats. In the prairies, it prefers large expanses of grassland, preferably with a shrub component. Population abundance is dependent on open grassland/shrubland during the mating season. According to Alberta Forestry, Lands and Wildlife (1991), "the retention of undisturbed grassland habitat is essential for the continued welfare of Sharp-tailed Grouse populations in Alberta." Initially, with settlement, the interspersion of large tracts of native vegetation with cropland areas benefited grouse distribution and numbers. However, "with the advent of modern, intensive clean-farming practices, populations have declined as the diversity has been decreased" (Nietfeld et al. 1985). Intensive grazing has also been known to cause declines in grouse populations (ibid.). The species is currently on the YELLOW A LIST for Alberta, but considered relatively common (AEP 1996).

Upland Sandpiper: This species "breeds from Alaska through the Canadian prairie and the northern United States south to Oklahoma and Texas (Finch 1992). It uses open grassy areas for foraging and nesting, rarely using cultivated fields. Once found extensively in the province, it now occurs primarily in the Grassland Natural Region, with only scattered populations elsewhere (Semenchuk 1992). The population status is unknown, but "populations probably have declined with loss of native prairie grassland nesting areas" (AEP 1996).

Western Meadowlark: This species nests on the ground in grassy areas with adequate cover to conceal the nest. While some studies suggest it is found only on non- or lightly-grazed grasslands, others suggest grazing intensity is not a factor (Prescott and Wagner 1996). The Western Meadowlark breeds from British Columbia east to southern Ontario and south to northern Mexico, central Texas and Louisiana (Godfrey 1986). The majority of breeding pairs in Alberta are found in the grasslands. There has been a long-term decline in numbers, particularly in parkland populations, perhaps due to a reduction in open grassland (AEP 1996). 
The following species are on the YELLOW B LIST for Alberta:

Bobolink: This species breeds throughout southern Canada, south as far as West Virginia, Pennsylvania and New Jersey (Godfrey 1986). In Alberta, it breeds irregularly in the central and southern areas of the province, preferring habitats such as open meadows and hayfields with tall grasses rather than native prairie (Semenchuk 1992). The Bobolink appears to be a species that expanded its range as settlers provided suitable habitat by developing pastures and hayfields (ibid.). This bird is included on the YELLOW в LIST since it is a species of localized distribution. Numbers are low, with less than 500 breeding pairs in Alberta (AEP 1996).

Brewer's Sparrow: This sparrow breeds in southeastern British Columbia, southern Alberta, southwestern Saskatchewan, and southwestern North Dakota south to California, Arizona and New Mexico (Godfrey 1986). There is a disjunct breeding population in the Yukon. Two subspecies occur in Alberta. The prairie subspecies nests in semi-arid areas, particularly in sagebrush communities in the Grassland Natural Region of Alberta (Semenchuk 1992). Although the population status is unknown, declines are suspected, in part due to the reliance of the prairie subspecies on native sagebrush habitats (AEP 1996).

Grasshopper Sparrow: "This sparrow breeds from southern Canada to the southern United States" (Semenchuk 1992). It is uncommon in Alberta. It has a restricted distribution, being found primarily in the grasslands. It nests on the ground in vegetation high enough to allow the nest to be at least partially covered. It prefers a "mixture of lush grasses and low, relatively open shrubbery" (Semenchuk 1992, p285). AEP (1996) states that this species prefers natural sandhill habitats, however, in a study of bird responses to grazing intensity, Grasshopper Sparrows were found only on tame pasture (Prescott and Wagner 1996).

Lark Sparrow: This is primarily a grassland species, found mainly in "semi-open areas in river valleys and coulees, as well as sandhills" (Semenchuk 1992, p281). It is "uncommon" and "locally distributed." It is "blue listed in B.C." and "a large portion of the Canadian range occurs in Alberta" (AEP 1996). In Canada, it breeds from the interior of British Columbia across the prairie provinces with a population in southwestern Ontario. It breeds as far south as southern California, northern Mexico, Louisiana and central Alabama (Godfrey 1986).

Rock Wren: This is primarily a grassland species, found mainly in areas with "large rock outcrops or the sparsely vegetated walls of valleys or canyons" (Semenchuk 1992, p213). It is also found in suitable habitat in the mountains. The Rock Wren nests in holes in rocks or cliffs. It breeds in interior southern British Columbia, southern Alberta and southern Saskatchewan to as far south as Costa Rica (Godfrey 1986, p408). It is "very local in distribution" (AEP 1996). "Alberta has about $30 \%$ of the Canadian distribution" but its habitat seems secure (ibid.).

Yellow-breasted Chat: In Alberta, this is a species of prairie riverine habitats. It prefers the dense shrub undergrowth of cottonwood stands. The current population status is unknown, and its distribution is considered very restricted (AEP 1996). It breeds locally in southern Canada (interior British Columbia, southeastern Alberta, southwestern Saskatchewan and southwestern Ontario), south to Mexico and northern Florida (Godfrey 1986). The British Columbia population of Yellow-breasted Chats has been listed as threatened by COSEWIC. 
Two species of landbirds known to occur in the grasslands are on the "STATUS UNDETERMINED" list for Alberta (AEP 1996). One, the Sage Thrasher, is listed by COSEWIC as endangered and was discussed in Chapter 1.6. The other, the Common Poorwill, breeds in semi-arid areas, preferring sagebrush. Although Common Poorwills have been sighted in Alberta since 1945, there are no confirmed records of a breeding pair.

\section{Raptors}

Raptor species that have been assigned status by COSEWIC were discussed earlier, in Chapter 1.6. These include the Burrowing Owl (endangered), the Ferruginous Hawk (vulnerable), the Peregrine Falcon (endangered) and the Short Eared Owl (vulnerable). Four additional Alberta raptors found in the grassland are species of concern, as follows.

Northern Harrier: This harrier is widespread, breeding from coast to coast and from Alaska south to Mexico (Campbell et al. 1990a). In Alberta it breeds in the Grassland, Parkland and southern Boreal Natural Regions. It hunts in open country and nests on the ground in areas of adequate cover, often among rose and buckbrush (Semenchuk 1992). Populations appear to be declining overall, especially in eastern North America (ibid.). Although Alberta populations were considered stable in 1992 ( $\mathrm{ibid}$ ), prairie and parkland populations in the province now appear to be declining, perhaps due to the deterioration of foraging and breeding habitats (AEP 1996). Finch (1992) lists a number of factors that have affected this species, including: agricultural conversion, overgrazing, accidental pesticide poisoning, disturbance and loss of habitat. This species is on the YeLLOW A LIST for Alberta.

Prairie Falcon: This falcon is a western North American species, breeding from south-central British Columbia through Alberta and southwestern Saskatchewan and south to Baja California, New Mexico and northern Texas (Campbell et al. 1990a). In Alberta, it breeds primarily in the Grassland Natural Region (Semenchuk 1992). It nests in cliffs of badlands, coulees and river valleys and hunts in adjacent grasslands. The species depends on "secure nest sites and [an] adequate ground squirrel prey base" (AEP 1996, p23). Declines in the range and population of this falcon have occurred in Canada. In the Okanagan Valley of British Columbia, for example, declines have been linked to human interference at nest sites, increasing use of organochloride pesticides and food deficiencies related to the population being at the northern limit of their range (Campbell et al. 1990a). In Alberta, the bounties that were in effect for this bird during the 1920s and 1930s could have reduced its historical range in the province. Although Semenchuk (1992) suggests that the Canadian population is stable and perhaps increasing, AEP (1996) concludes that population trends in Alberta are unclear and, therefore, it has been placed on the YELLOW A LIST.

Swainson's Hawk: This hawk breeds primarily in southern Alberta, southern Saskatchewan and southwest Manitoba, and south to Mexico (Godfrey 1986). "Swainson's Hawk breeds in dry, open country where trees and shrubs are available for nesting. Highest densities of this hawk [in Alberta] are found at the prairie/parkland border" (Semenchuk 1992). Ground squirrels are one of its main foods. Aggregations of "300 to 400 birds feeding on grasshoppers" were reported in 
1893 in British Columbia, but no aggregations of this magnitude have been reported since the 1920s (Campbell et al. 1990a). Declines in British Columbia were related to declining cricket and grasshopper prey on the breeding grounds, declining locusts on the wintering grounds and persistent shooting (ibid.). There have been "sharp declines in prairie populations over the last decade", in part due to mass poisoning in their wintering areas (AEP 1996). This species is on the YELLOW A LIST for Alberta.

Golden Eagle: This eagle is widespread, found throughout North America to central Mexico and also occurring in Europe and Asia. Once the target of an eradication program, populations dropped, but they now appear to be stable or increasing (Campbell et al. 1990a). The Golden Eagle "prefers open areas with short or sparse vegetation, especially slopes and plateaus that allow a commanding view" (Semenchuk 1992). Although found in other scattered locations, the main Alberta populations are concentrated in the mountains and along the major river valleys in the grasslands. In the grasslands, it nests in badlands, coulee edges and river valleys. The Golden Eagle is on the YELLOW B LIST for Alberta as a species with a low but apparently stable population of 100 to 250 breeding pairs (AEP 1996).

\section{Reptiles and Amphibians}

Patriquin (1993, p45) lists several priority reptile and amphibian species for the prairie biome. These include Canadian (Dakota) Toad, Great Plains Toad, Northern Leopard Frog, Plains Spadefoot Toad, Painted (Western Painted) Turtle, Short-horned Lizard and Western Hognose Snake. Most of these species are considered at risk and all depend on "adequate, quality habitat at critical seasons for their continued viability" (Fisher and Roberts 1994, p15).

Canadian Toad: This is a central North American species, found from the Northwest Territories south through eastern Alberta to about the latitude of Lake Newell, through most of Saskatchewan and south-central Manitoba, south to South Dakota and east to northern Minnesota (Russell and Bauer 1993). It breeds in shallow, often temporary waterbodies. Significant population declines of this species have been documented since 1986 across its Alberta range, especially in agricultural areas (Patriquin 1993, p41). It was "once common in boreal and parkland habitats" but there has been a "dramatic decline in [the] parkland distribution." It is on the RED LIST for Alberta (AEP 1996, p19).

Great Plains Toad: This toad is found in the southeast corner of Alberta. This is the northwestern edge of a range that extends to southeast Saskatchewan, through Montana and south to Mexico (Russell and Bauer 1993). It is a "rare prairie resident. Total populations are unknown, but apparently declining" (AEP 1996, p19). This toad breeds in clear, shallow water of marshes, streams and temporary waterbodies. A number of threats have been noted, including the decline of breeding habitat due to "drought, drainage and cultivation of wetlands. Clean water, apparently required for breeding, can be compromised by intensive livestock use of breeding area ponds" (ibid.). This species is on the RED LIST for Alberta (AEP 1996, p19). 
Northern Leopard Frog: This species "is distributed widely across the United States, Mexico and Canada" (Finch 1992). It lives in permanent waterbodies with abundant vegetation (Russell and Bauer 1993). The Northern Leopard Frog has experienced "a catastrophic decline in numbers and range" (Powell and Russell 1996). Once found in Alberta north to the Little Smoky River, it is now found only in the prairie biome (Russell and Bauer 1993). Most of the populations remained healthy until about 1979. They then began to disappear from many sites in the central and southern parts of the province. According to Roberts (1992), all populations have disappeared north of 51 degrees latitude. "Populations south of this line have also suffered in recent years, and those remaining are limited to small areas around springs, seeps, creeks or small ponds" (Patriquin 1993, p41). This species is on the RED LIST for Alberta due to the severe decline in numbers. It is considered extirpated from the North Saskatchewan River drainage basin (AEP 1996, p19).

Plains Spadefoot Toad: In Alberta, this toad is found south of the Red Deer River and west to Pincher Creek. The Alberta population is at the northwestern limit of a range that extends east to Manitoba and south to Mexico and eastern Arizona (Russell and Bauer 1993). It has a "highly variable" population, based on "annual availability of breeding ponds" (AEP 1996, p20). Breeding ponds are usually temporary waterbodies in areas with "sandy or friable soil appropriate for burrowing" (Russell and Bauer 1993, p62). Drought combined with wetland drainage and basin cultivation has likely decreased available habitat. The Plains Spadefoot Toad is on the BLUE LIST for Alberta (AEP 1996, p20).

Scientists have had difficulty explaining the worldwide disappearance of many amphibian species. Causes may involve a combination of unusual local conditions related to drought, frost, disease, acid rain and loss of habitat. Other possible causes include global warming, introduction of exotic competitors, predators, pathogens, changes in ultraviolet radiation levels and the general contamination of air, soil and water (Heyer 1996, p11; Microsoft Internet Explorer 1996). According to Heyer (1996, p11), "the single greatest threat to amphibian disappearances is habitat modification."

Fisher and Roberts (1994, p21) propose that "wetland drainage, upland cultivation, and the use of chemicals have all contributed to the dramatic decline of the Northern Leopard Frog, Canadian Toad and Great Plains Toad in Alberta." Amphibians are extremely sensitive to water pollutants such as pesticides and herbicides. Fisher and Roberts (1994, p21) also postulate that these factors are probably responsible for eliminating much of the historical amphibian and reptile community on one of their study areas - the Medicine Wheel Landscape. Loss, degradation and fragmentation of habitats have all affected the reptile and amphibian populations of the prairies.

A number of prairie reptile species are also of concern. Three, the Short-horned Lizard, the Prairie Rattlesnake and the Western Hognose Snake, are on the BLUE LIST for Alberta. The Shorthorned Lizard is listed by COSEWIC as a vulnerable species and was discussed in detail in Chapter 1.6.

Prairie Rattlesnake: The Prairie Rattlesnake ranges from south-central British Columbia across to southern Saskatchewan and south to Baja California, north-central Mexico and eastern 
Nebraska (Russell and Bauer 1993). This snake is considered a relatively common but localized species, preferring dryer areas with sandy soils. Russell and Bauer (1993) suggest that the distribution of the Prairie Rattlesnake has been shrinking. Saskatchewan populations are apparently in decline, but Alberta population trends are unknown (AEP 1996). Human-caused mortality continues to be a factor, and hibernacula are particularly vulnerable.

Western Hognose Snake: This snake ranges through southern Saskatchewan, western Manitoba and south to Mexico (Russell and Bauer 1993). In Alberta it is known only from the very eastern part, primarily south of the Red Deer River. It "shows a preference for sandy locations and damp lowlands" (ibid., p95). Wallis and Wershler (1988) propose that populations are declining, due largely to human-caused mortality. Russell and Bauer (1993) suggest that its available habitat has been reduced and that it is "now much less common than it once was." Hibernacula are particularly vulnerable. AEP (1996) indicates that the species is extremely rare, and that population trends are unknown.

The three species of garter snake in Alberta are also considered species of concern and are on the province's YELLOW A LIST. The Plains Garter Snake and the Wandering Garter Snake are primarily grassland species. Both are considered "common but localized" (AEP 1996). There apparently is a common perception that the Plains Garter Snake has been undergoing a longterm decline in numbers (ibid.), however, population trends for both species remain essentially unknown.

Reptile species on Alberta's YelLow B LIST include the Bull Snake and Western Painted Turtle. Found in dryer grassland or sagebrush areas, the population of the Bull Snake is considered "stable or possibly declining" (AEP 1996, p24). The Western Painted Turtle is known from very few localities in the province - all in the Milk River drainage. In Alberta, this turtle is low in numbers and, therefore, is "particularly vulnerable to site-specific habitat loss" (ibid.).

\section{Fish}

There are 51 native and 8 introduced fish species in Alberta (Nelson and Paetz 1992). Several species that occur within the lakes and rivers of the Grassland Natural Region have been classified by the Alberta Natural Heritage Information Centre (ANHIC) as "trackable species" (i.e., species that either have a limited distribution and small populations, or for which current information is lacking). Species provincial ranks are defined on page 50. The trackable species that occur in the grasslands of the province are discussed below. One additional species is also on the tracking list - the St. Mary River Shorthead Sculpin. It has been discussed earlier in Chapter 1.6 as a species under review.

As Ostlie et al. (1996, p84) suggest, the "conversion of natural vegetation coupled with mechanical alteration of river and stream habitat (e.g., by dams, road-building, etc.) has greatly impacted the fish fauna of the prairie biome." Alberta has not escaped these impacts. 
Arctic Grayling (Belly River population): This grayling is widespread in northern Canada, including the Hay, Peace, and Athabasca river drainages in Alberta. "Specimens have occasionally been taken from the Belly River in the Oldman River drainage" (Nelson and Paetz 1992). This fish is "confined to cool streams and lakes and is extremely susceptible to various forms of pollution" (ibid.). Larger fish are often rapidly depleted from rivers and creeks by sportfishing activities. Arctic Grayling within the Belly River only have been ranked by ANHIC as an S5T1 species due to a lack of current records and observations.

Brassy Minnow: This species is distributed from Alberta and Colorado to New York; with some scattered localities in British Columbia. In Alberta, it is known from the Milk River drainage, Musreau Lake, the Athabasca River and House River (Nelson and Paetz 1992). "Brassy minnows in the Milk River drainage occur in slow currents, including 'alkali' streams" (ibid.). The Brassy Minnow has been ranked by ANHIC as an S1 species for Alberta.

Bull Trout: This species occurs in northwestern North America from southern Alaska to California. In Alberta, it is known from the Peace, Athabasca, North Saskatchewan, Red Deer, Bow and Oldman river drainages (Nelson and Paetz 1992). "There has been a significant reduction in the range of this species..., especially in the eastern portion of their range in Alberta" (ibid.). According to Alberta Environmental Protection (1996a), the Bull Trout has been eliminated from most of its historic prairie range primarily because of "habitat changes and overfishing". One of the last populations of this species on the prairies, currently found in the downstream reaches of the Oldman River, is under threat and may "disappear if its migration path continues to be blocked" by dams (Nelson and Paetz 1992). The Bull Trout has been ranked by ANHIC as an $\mathrm{S} 3$ species for the province.

Cutthroat Trout: The interior form of this species occurs in "southeastern British Columbia, southwestern Alberta and Montana" (Nelson and Paetz 1992). In Alberta, it is "native to the Bow and South Saskatchewan river drainages" (ibid.). Due primarily to interbreeding between stocked and native populations, there are currently few native populations left in Alberta. No native populations remain within the prairies (ibid.). The native populations of Cutthroat Trout have been ranked by ANHIC as S1 for the province.

Lake Sturgeon: This species is "known in Alberta from the North Saskatchewan, lower Red Deer, lower Bow, lower Oldman, and South Saskatchewan rivers" (Nelson and Paetz 1992). In the South Saskatchewan River in Alberta, it is common only "upstream to the junction of the Bow and Oldman rivers". Factors such as water pollution and changes in river ecosystems as a result of developments are believed to affect sturgeon populations. In 1989, "the American Fisheries Society declared the lake sturgeon to be threatened" (ibid.). For Alberta, the Lake Sturgeon has been ranked by ANHIC as an S3 species.

Quillback: The Quillback is found from Alberta to southern Quebec and eastern Missouri to Virginia. It is known from "central and southern Alberta from the North Saskatchewan, Battle, Red Deer, lower Bow, lower Oldman, and South Saskatchewan rivers" (Nelson and Paetz 1992). In Alberta, the Quillback "has been recorded from sluggish and usually turbid rivers but not from lakes. Nothing is known of their spawning habits in Alberta" (ibid.). It has been ranked by ANHIC as an S2 species for the province. 
River Shiner: This shiner is found from Alberta to eastern Manitoba, south to Oklahoma and eastward to Pennsylvania. "It is sporadic in central and southern Alberta" (Nelson and Paetz 1992). It occurs in the North Saskatchewan, Red Deer, lower Bow, lower Oldman, and South Saskatchewan rivers (ibid.). This species prefers large streams that flow over sandy and gravel substrates. It has been ranked by ANHIC as an $\mathrm{S} 2$ species for Alberta.

Silver Redhorse: This fish is found from Alberta to southern Quebec and Missouri to northern Georgia. In Alberta, it is known "only from the North Saskatchewan River between Devon and the Sturgeon River..., and the South Saskatchewan River at Medicine Hat" (Nelson and Paetz 1992). The Silver Redhorse "frequents large rivers, especially pools or areas of slow gradient. It has not yet been found in any Alberta lakes" (ibid.). Information is lacking on the biology of this species in Alberta. It has been ranked by ANHIC as an S2 species for the province.

Spoonhead Sculpin: This fish occurs from "northeastern British Columbia to Quebec with northward extensions to the mouth of the Mackenzie River and southward to Michigan" (Nelson and Paetz 1992). In Alberta, it is known from the "Slave, Peace, Athabasca, North Saskatchewan, upper Red Deer, Bow and upper Oldman river drainages." It is "most abundant in streams in the foothills and adjacent plains" (ibid.). The Spoonhead Sculpin has been ranked by ANHIC as an $\mathrm{S} 3$ species for the province.

Stonecat: The Stonecat is found from Alberta to southern Quebec, south to Oklahoma and eastward to Tennessee. In Alberta, it is known "only from the Milk River or the lower reaches of some of its tributaries" (Nelson and Paetz 1992). This fish occurs in a variety of river and stream habitats. "It is most commonly associated with boulders in deep pools and over rocky bottoms in currents or riffles of large streams, both turbid and clear" (ibid.). It has been ranked by ANHIC as an $\mathrm{S} 1$ species for the province.

Western Silvery Minnow: This minnow is found in "southern Alberta to southern Manitoba and southward through the Missouri drainage to near the confluence of the Missouri and Ohio rivers" (Nelson and Paetz 1992). In Alberta, it is known from the Milk River and possibly from the South Saskatchewan River at Medicine Hat (ibid.). Very little is known about this species in Alberta and it has been ranked as an S1 species by ANHIC.

One other fish species is on the tracking list for Alberta - the Rainbow Trout. Although this species is currently distributed throughout much of the southern part of Alberta (Nelson and Paetz 1992), the populations that are now present within the prairies originated from introduced stock and are, therefore, not native to the area. For those native populations of Rainbow Trout that occur elsewhere in Alberta, they have been given a rank of S2 by ANHIC.

\section{Mammals}

A number of mammal species that inhabit the grasslands are on the lists of species of concern for Alberta. The Black-footed Ferret (extirpated), Swift Fox (RED-LISTED) and Ord's Kangaroo Rat (BLUE-LISTED) were discussed in Chapter 1.6. Those species found in prairie habitats and that are on the YELLOW A LIST for Alberta are discussed below. 
American Badger: Badgers are found from central Mexico north through the central and western United States to the Great Lakes and into southern Ontario, southwest Manitoba, central Saskatchewan, central Alberta and southeastern British Columbia (Banfield 1974). In Alberta, badgers are essentially restricted to the Grassland and Parkland Natural Regions (Smith 1993). They rely on ground squirrels and pocket gophers for prey. Badger burrows "provide a key habitat element for Burrowing Owls" (AEP 1996, p23). Population trends are presently unknown (ibid.).

Long-tailed Weasel: This weasel is widespread, ranging from southern Canada to South America (Banfield 1974). It is a species of the "grassland, parkland and coniferous forests" and is found throughout the southern two-thirds of the province (Smith 1993). AEP (1996) suggests that this species is disappearing from some areas as habitat is lost. Smith (1993) indicates that the grassland populations may be in decline, but evidence is lacking.

Richardson's Ground Squirrel: As a central Plains species, it reaches the northwestern limit of its range in Alberta's grassland and parkland areas (Banfield 1974). Although a common species, populations are in decline and, therefore, it was placed on the YELLOW A LIST for Alberta (AEP 1996). The decline is thought to be caused by "effective poisoning campaigns and habitat alteration ... Populations [are] increasingly fragmented and restricted to remnants of unbroken ground" (ibid., p24). The Richardson's Ground Squirrel is an important species to the ecology of the grasslands. It is a key prey of species such as Ferruginous Hawk (BLUE-LISTED), Prairie Falcon (YELLOW A-LISTED), Swainson's Hawk (YELLOW A-LISTED) and Badger (YELLOW A-LISTED). It'S burrows may be a critical component of Burrowing Owl (RED-LISTED) nesting habitat.

Thirteen-lined Ground Squirrel: This species is found from east-central Alberta across to Manitoba. Its range continues east to south of the Great Lakes to Ohio and south in the Great Plains to the Gulf of Mexico (Banfield 1974). In Alberta, it is a species of the southern parklands and grasslands. It does not appear to occur in the Dry Mixedgrass Subregion of the Grassland Natural Region (Smith 1993). There is some concern that populations may be declining, but the status is essentially unknown (AEP 1996).

Seven grassland mammals are on the YelLOw B LIST for Alberta - Bobcat, Northern Grasshopper Mouse, Nuttall's Cottontail, Olive-backed Pocket Mouse, Pronghorn, Western Harvest Mouse and Western Small-footed Bat. Each of these is discussed below.

Bobcat: This wide-ranging species is found throughout southern Canada, north to central British Columbia and south throughout the United States and into Mexico (Banfield 1974). In Alberta's grasslands, it is basically restricted to the coulees and river valleys south of the South Saskatchewan River. It does, however, range further north in the foothills and front ranges (Smith 1993). Populations are low (less than 1000 individuals) but "presumed stable" (AEP 1996, p29).

Northern Grasshopper Mouse: This mouse is found within the North American Plains from the Gulf of Mexico north to the Canadian prairies (Banfield 1974). In Alberta, it is restricted to the southeast where it is "found on open, sandy, grassland habitat, interspersed with sagebrush" (AEP 1996). It is of concern due to its restricted distribution, but population levels are unknown (ibid.). 
Nuttall's Cottontail: This is a species of the grasslands. It ranges from southeastern Alberta and southwestern Saskatchewan to New Mexico (Banfield 1974). It is found in southeast Alberta in "river bottomlands, rocky valley sides, and areas of scrub brush on the grasslands" (Smith 1993). Although Smith considered it common in Southern Alberta, AEP (1996) suggests that populations are small (less than 5000) and available habitat may be declining.

Olive-backed Pocket Mouse: This Central Plains species ranges from southeastern Alberta across southern Saskatchewan to the southwestern corner of Manitoba and south to California. It is also found in south-central British Columbia (Banfield 1974). This pocket mouse is found in open grassland, preferably with sandy soil (Smith 1993). Population status is unknown.

Pronghorn: Pronghorn occur throughout the Great Plains, the high sagebrush steppes and valleys of the Great Basin, and portions of south-central Canada and northern Mexico. They reach the northern limits of their North American range in the grasslands of south-central Canada. From herds historically in the millions, their numbers had dropped to about 20,000 animals by 1908 (Banfield 1974). Populations have since increased significantly, but they remain extirpated from areas of their former range (ibid.). Pronghorn typically avoid rugged areas and dense, tall vegetation that restricts their visibility (Ockenfels et al. 1996).

They most frequently occupy grassland and sagebrush (i.e., Artemisia cana) communities. According to FEIS (1996), the North American Pronghorn population (1962 figures) was distributed as follows: $41 \%$ in shortgrass communities, $21 \%$ in mixed grass communities, $33 \%$ in sagebrush-bunchgrass communities, with the remaining $5 \%$ in various other community types.

Pronghorn are usually limited by "large tracts of intensively cultivated land where protective cover and suitable forage is scarce and fences impede movements" (Nietfeld et al. 1985). They are also affected by shrub and tree encroachment (Ockenfels et al. 1996). Highways and railways fragment their habitats and impede travel, particularly when fenced on both sides (ibid.). This becomes critical in severe winters if migration to suitable wintering habitat is blocked.

Their "population levels fluctuate depending on winter and summer climatic conditions" (AEP 1996, p29). This situation was a determining factor for including this species on the YELLOW B LIST for Alberta.

Western Harvest Mouse: This species is found in the arid grasslands of central North America and the central Mexican plateau (Banfield 1974). The range of this harvest mouse just reaches into Canada, into extreme southeastern Alberta, southwestern Saskatchewan and the interior of British Columbia (Banfield 1974, Smith 1993). The population status is unknown (AEP 1996).

Western Small-footed Bat: This is a grassland species found in "rocky outcrops and crevices in badland areas" (Smith 1993) as well as riverine habitats (AEP 1996). It has a clumped distribution and although generally uncommon, can be common in appropriate habitats (Smith 1993). The general population status is unknown, but there is "concern for habitat security because of clumped, disjunct populations" (AEP 1996). 
There are nine mammals of undetermined status in Alberta (AEP 1996). Of those nine, five occur in the grasslands - Hoary Bat, Long-eared Bat, Long-legged Bat, Prairie Shrew and Sagebrush Vole (AEP 1996).

Hoary Bat: This bat is found throughout the United States and central Mexico, reaching the northern edge of its range in Canada (Banfield 1974). In Alberta, it is found in coniferous and deciduous forests throughout most of the province. When observed in Alberta's grasslands, it is usually found along river valleys (Smith 1993).

Long-eared Bat: This species is found from Baja California north to central British Columbia and east to southwestern Saskatchewan (Banfield 1974). In Alberta it is found in the mountains north to Jasper and the grasslands north to Trochu. This bat shelters in rock outcrops in coulees and river valleys (Smith 1993).

Long-legged Bat: This bat occurs from northern British Columbia south to Mexico and east to southern Alberta and Montana (Banfield 1974). In Alberta, this bat is known only from the mountains and the Milk and South Saskatchewan rivers (Smith 1993). The Long-legged Bat relies on shelters in rock outcrops in coulees and river valleys.

Prairie Shrew: This shrew is a species with a restricted distribution, found only in the northcentral plains of North America (van Zyll de Jong 1983). In Alberta, it is found primarily in the prairies and parklands, preferring "dense vegetation, shrubby areas, and meadows" (Smith 1993).

Sagebrush Vole: This vole is found in the arid plains and mountains of central North America as far north as southern Alberta and south-central Saskatchewan (Banfield 1974). It is a grassland species, found only where sagebrush is common (Smith 1993).

Of the 26 RED-, BLUE- and YELLOW-LISTED mammal species in Alberta, one-half are species with at least part of their range in the grasslands. 


\section{Chapter 1.8 What is Being Done?}

Many individuals, groups, agencies and industries are aware of the state of prairie habitats and species and have taken steps to help conserve and restore those ecosystems. Much is being accomplished on a variety of fronts. Some of the programs, plans and initiatives include:

- The Ramsar Convention

- Prairie Habitat Joint Venture under NAWMP

- The Mixedgrass Prairie Habitat Restoration Project under NAWMP

- Adopt-a-Pothole Program

- Prairie Shores Program

- Wetlands for Tomorrow Program

- Recovery of Nationally Endangered Wildlife Program

- Endangered Species Recovery Fund

- Prairie Care Program

- Heritage Marshes Program

- The Alberta Prairie Conservation Action Plan

- Operation Burrowing Owl

- Operation Grassland Community

- Landowner Habitat Program

- Riparian Habitat Management Program

- Wildlife Habitat Development Program

- The Permanent Cover Program

- Alberta Water Management \& Erosion Control Program

- Soil Conservation Area Program

- Fisheries Management Enhancement Program

- Fisheries Habitat Development Program

- Buck for Wildlife Program

Since the release of the Prairie Conservation Action Plan (PCAP) in 1988, considerable effort has been put forward and accomplishments made to meet its goals focusing on the preservation of native prairie. Those goals were: (1) identify the remaining prairie, (2) protect at least one large, representative area in each of the four prairie subregions, (3) establish a system of protected native prairie ecosystems and connecting corridors, (4) protect threatened ecosystems by implementing habitat restoration and management plans, (5) protect and enhance populations of vulnerable, threatened, endangered, or extirpated prairie species, (6) ensure that no additional species become vulnerable, threatened, endangered, or extirpated, (7) encourage government to incorporate the conservation of native prairie into their programs, (8) encourage the sustained use of private land while maintaining and enhancing the native biological diversity of the prairies, (9) promote public awareness of the value and importance of prairie species, and (10) promote research into prairie conservation (World Wildlife Fund 1988). PCAP's accomplishments are documented in its 1994-1995 Annual Report (Prairie Conservation Forum 1996). 
In February of 1997, the Alberta Prairie Conservation Action Plan was released as a successor to the 1988 Prairie Conservation Action Plan that was prepared for Canada's three prairie provinces. The Alberta PCAP "promotes the conservation of native prairie and parkland species and habitats while affirming the importance of community cooperation and respecting the stewardship of local landholders" (Creasey 1997). The plan's four goals are: (1) advance the identification, understanding and use of information about Alberta's prairie ecosystems, (2) ensure governments at all levels have in place policies, programs and regulations that favour the conservation of Alberta's native prairie ecosystems, (3) adopt land use management practices and protective strategies across the whole prairie landscape that sustain diverse ecosystems, and (4) increase awareness of the values and importance of Alberta's native prairie ecosystem (Prairie Conservation Forum 1997).

Many groups and individuals across Canada have cooperated under the North American Waterfowl Management Plan to restore wetlands and associated habitat critical to the breeding, staging, and wintering of many species of wildlife. Partners have conserved and enhanced over a half million hectares of wetland and other habitat in Canada (e.g., the 19,000 ha Medicine Wheel project in Alberta). They have also encouraged land use practices to enhance the value of agricultural land to wildlife. Today, assisted by several seasons of high precipitation, waterfowl numbers are increasing and other species are benefiting (NAWMP 1996).

The Energy Resources Conservation Board, along with several Alberta Government agencies, has compiled guidelines for reducing disturbance on native prairie areas (ERCB 1992). These agencies are working with industry to monitor the effectiveness of the guidelines in reducing the loss of native prairie grassland to oil and gas projects. Some recent efforts of industry in attempting to minimize the disturbance to native prairie areas are encouraging. For example, the Express Pipeline Project, which extended from Hardisty to Wildhorse in Alberta (National Energy Board 1996), incorporated several mitigation techniques in their construction and operation plans, including:

- choosing construction schedules (i.e., August to November) to avoid nesting seasons and critical life-cycle phases of fish species,

- shifting alignments, where possible, to avoid wetlands and lakes, significant plant communities and other valued natural areas,

- scheduling cleanup activities to avoid important occupied denning and reproductive habitats,

- restricting topsoil stripping to an area only slightly wider than the ditch wherever possible,

- employing soil erosion control measures (e.g., mulching),

- installing temporary fencing to protect river banks,

- washing mud and vegetative debris off equipment to prevent weed transfer,

- using native seed mixes, as much as possible, for reclamation, and

- revegetating riparian areas along affected rivers using local native plant species.

Within the agricultural community there are several ongoing projects to reduce degradation of riparian areas, and to increase the value of arable and pasture lands to wildlife (Alberta Environmental Protection 1994a, 1996a; Bentley 1988; NAWMP 1996). These include: 
- the use of conservation tillage practices (e.g., trash cover farming),

- rotational grazing practices,

- under the Riparian Habitat Management Program, livestock grazing management strategies are being developed and tested for the protection of streams and riparian areas,

- restoration of native grass communities,

- the involvement of agricultural scientists in the development of mitigative and protective methodologies,

- agricultural research efforts regarding soil and crop management practices that maintain and protect the productivity of cultivated farmlands,

- taking marginal land out of cultivation. For example, "since 1989, more than 144,000 ha of environmentally sensitive farmland in Alberta was returned to permanent cover of grass or trees" (Alberta Environmental Protection 1994a),

- establishment of permanent forage on marginal lands,

- farmers who are actively involved in maintaining and improving the productivity of their cultivated lands (e.g., reduced or zero tillage, new harvest techniques, replenishment of nutrients, crop rotations), and

- the establishment of farming and ranching associations whose purposes are to address soil degradation problems.

Much remains to be done to reverse or mitigate the decades of loss and degradation of both upland and wetland habitats, soil quality, and water quality and flow patterns. Because of the scale of grassland loss and the wide-ranging nature of most animal species adapted to the prairie environment, "the recovery of many plant and animal species associated with native prairies will likely require management of large landscapes in ways other than full restoration to preagricultural conditions; specifically, in ways compatible with sustainable agriculture" (Anderson et al. 1995, p404-5). For endangered species, in particular, it is increasingly recognized that "future recovery efforts must be broadened to include public participation and emphasize ecosystem-based management" (Dauphine 1996, p1).

Since prairie farmers and ranchers often own much of the land in an area, they must be involved in any large-scale recovery, restoration or conservation initiatives. Although restoration of some private lands may be possible (e.g., marginal lands), "it is not reasonable to assume that many large tracts of productive privately owned agricultural lands can be retired from agricultural use" (ibid.). Baydack et al. (1995, p395) suggest that "effective grassland conservation in the prairie landscape of Canada only can come about through revitalized rural communities supported by more diverse and stable income opportunities that are economically and environmentally sustainable."

Restoration of degraded habitats and landscapes will "require much more than just establishing protected areas" (Sinclair et al. 1995). For renewal,

"...it will be necessary to focus attention on combinations of activities, including protection and enhancement of native remnants, managed grazing systems, and sound soil and water conservation practices which should, collectively, provide for a more diverse, wildlife-friendly prairie landscape than exists over much of central North 
America today. There is a need to develop the means of providing new habitat in a wide range of situations and locations to offset the loss of original habitat" (ibid.).

Establishing protected areas, however, is an effective and practical tool that can be used to conserve ecosystems and species. Protected areas maintain ecosystems and populations of native species, and thus act as storehouses of irreplaceable genetic information. Apart from their invaluable role in the conservation of biodiversity, protected areas provide many other services and benefits (Hummel 1989; Nelson 1993). One of their most important functions is to serve as ecological benchmarks or "baselines", against which we can evaluate the quality of our management strategies for the vast majority of terrestrial and aquatic environments that lie outside such areas. In the coming millennium, protected areas could well constitute our lifelines to an ecologically and economically sustainable future.

The Alberta Government recognizes the need to protect the natural variety of Alberta's species and spaces within a system of protected areas. Implementing Alberta's Special Places initiative, announced March 28, 1995, is a key step.

The document Special Places 2000: Alberta's Natural Heritage -- Policy and Implementation Plan contains the Alberta government's Special Places 2000 policy statement, as follows:

"The Vision for Special Places 2000, Alberta's strategy, is to complete a network of Special Places that represent the environmental diversity of the province's six natural regions (20 subregions) by the end of 1998" (Government of Alberta 1995, p5).

In addition to preserving Alberta's natural heritage, the Special Places policy has three other goals - outdoor recreation, heritage appreciation and tourism/economic development.

One of the seven guiding principles of Special Places 2000 is that: "the land classification system called Natural Regions (subregions) and Natural History Themes provides the scientific basis for the identification, review and designation of Special Places." According to Alberta Environmental Protection (1994b), "the purpose of the natural regions' classification ... is to account for the entire range of natural landscape diversity in Alberta" ... and this scheme ... "best represents the ecosystem and biodiversity elements of importance to protected areas."

The next part of this report details the application of a land classification system in selecting a candidate protected areas network for Alberta's Grassland Natural Region. 


\section{PART 2}

A Protected Areas Network for the Grassland Natural Region 


\section{Chapter 2.1 Designing a Protected Area's Network for the Grasslands.}

The following discussion has been taken primarily from the July 1996 report entitled, "Selecting Protected Areas: the Foothills Natural Region of Alberta" (Alberta Environmental Protection 1996).

\section{Theory}

By far the oldest and most familiar strategy for conserving Canada's landscapes, animals and plants is the establishment and management of parks, reserves or other forms of protected areas; but what is meant by the term "protected area?" Many definitions exist, but central to all officially accepted versions are three basic criteria: 1) the site must be legislated, 2) the protection of natural heritage values must be a fundamental reason for the site's establishment and, 3) management guidelines and monitoring programs must be instituted to ensure the site's long-term protection.

The United Nations "Brundtland Commission Report" (World Commission on Environment and Development 1987) defined protected areas as being "managed explicitly to conserve species and ecosystems." Genuine protected areas are managed so that: a) natural processes and forces are allowed to operate with minimal human interference and, b) all non-human forms of life can freely exercise their intrinsic right to exist for their own sakes. Because they preserve landscapes, ecosystems and habitats, protected areas play an increasingly vital role in the on-going effort to conserve Earth's biological diversity.

According to Cooperrider (1994), four fundamental objectives need to be pursued to maintain native biodiversity in perpetuity:

1. Represent in a system of protected areas all native ecosystem types and developmental stages across their natural range of variation.

2. Maintain viable populations of all native species in natural patterns of abundance and distribution.

3. Maintain ecological and evolutionary processes, such as disturbance regimes, hydrological processes, nutrient cycles and biotic interactions.

4. Manage landscapes and communities to be responsive to short-term and long-term environmental change, as well as to maintain the evolutionary potential of the biota.

With the advent of World Wildlife Fund (WWF) Canada's Endangered Spaces campaign and the subsequent signing of the Aylmer Declaration, the first of these objectives has been formally 
adopted by Canada's federal, provincial and territorial governments. They have committed to "make every effort to ... complete Canada's networks of protected areas representative of Canada's land-based natural regions by the year 2,000 ... " (pg. xiv in Hummel 1995). This commitment, with its emphasis on the "representativeness" of a reserve network, heralds a radical departure from past practices whereby protected areas tended to be selected for their uniqueness or rarity.

Reed Noss, one of the world's foremost conservation biologists, has summarized the legacy of our traditional rationale for protected area selection as follows: "our present system of reserves is far from ideal. National parks and other reserves in most parts of the world, including Canada, were selected to preserve spectacular scenery and provide recreational opportunities, while conflicting minimally with commodity production objectives (Noss and Cooperrider 1994)." Furthermore, "besides being an inadequate representation of Canada's natural diversity, existing parks and other reserves were poorly designed. Many are becoming ecological islands as surrounding lands are intensively developed" (Noss 1995, pp. 61-62).

However, over the last decade or so, major advances have been made in placing the selection and design of protected areas networks on a firmer, more rigorous, scientific footing (see, for example, Canadian Council on Ecological Areas 1992; Achuff and Wallis 1992; Lewis 1993; Noss and Cooperrider 1994; Kavanagh et al. 1995; and many others). Using two studies it commissioned (viz. Kavanagh et al. 1994, and Noss 1995, respectively), WWF Canada has developed "standard procedures" for: (a) the selection of representative protected areas based upon a gap analysis utilizing enduring features and, (b) the evaluation and employment of specific, reserve-network design criteria intended to maximize the probability that their component protected areas will maintain their ecological integrity over the long term. With their strongly Canadian perspective, these two recent publications are relevant to the grassland's situation and are drawn upon extensively in the following account.

WWF Canada's gap analysis methodology is based initially on mapping natural regions and identifying the enduring features within them. By ensuring that representative examples of each natural region's enduring features are included within protected areas, it is hoped that its full range of biodiversity will also be represented. However, as exemplified by Kirkpatrick and Brown's (1994) comparison of the use of physical attributes versus biological data as protected area selection criteria in Tasmania, exclusive use of physical features can result in the omission of many rare species and communities. Noss $(1995, \mathrm{p} 13)$, summarizing the results of this and analogous studies, cautions "final reserve selection decisions should not rely entirely on an enduring features gap analysis (since) critical biological elements would almost surely be missed."

Noss (1995) defines protected area networks as consisting of three integral components, i.e., highly protected core reserves, multiple-use buffer zones (cf. Wells and Brandon, 1993) and linkages with other reserves (see, for example, Taylor et al. 1993, for a discussion of the importance of connectivity). To supplement the above-described gap analysis he recommends the use of various "additional criteria for selecting core areas." Employing Noss' criteria, WWF gives priority to the following kinds of sites (Kavanagh et al. 1995, p7): 
1. Roadless, undeveloped, or otherwise essentially wild areas of significant size. Undeveloped areas, especially when they are less accessible to humans, or when they offer refuge to species sensitive to human activities.

2. Concentrations of rare species. These are obvious "hot spots" of biodiversity that should be included within reserves.

3. Areas of unusually high species richness. These are areas where many different species can be protected efficiently.

4. Unusual plant or animal communities, forest succession stages (such as old-growth), or animal concentration areas such as bird or seal breeding sites; waterfowl staging areas; winter-range or calving grounds for caribou, moose, or elk; bear denning area (etc.).

5. Sites with unusual habitat conditions, such as artesian springs, ice-free bays, outcrops of unusual rocks or surface material, and mineral licks.

6. Watersheds of high value for fish or other aquatic life.

7. Sites that are sensitive to development, such as watersheds with steep slopes or unstable soils.

8. Sites recognized as important or sacred by aboriginal peoples.

9. Sites that could be added to existing protected areas to form larger areas with greater ecological integrity.

As stressed by Noss (1995), "representation of ecosystems ... is only the first step in the process of conserving biodiversity. Keeping species from extinction requires attention to reserve design issues that transcend representation." Maintaining the long-term ecological integrity of potential reserves is the second fundamental issue that governs the selection and design (and ultimate management) of candidate protected area sites. Noss $(1995, \mathrm{p} 1)$ outlines "three major objectives for maintaining ecological integrity in representative reserve networks," namely:

1. Sustain key geomorphological, hydrological, ecological, biological; and evolutionary processes within normal ranges of variation, while building a conservation network that is adaptable to a changing environment;

2. Maintain or restore viable populations of all native species in natural patterns of abundance and distribution; and

3. Encourage human uses that are compatible with the maintenance of ecological integrity." 
For further discussion of the objectives listed above, see Kavanagh et al. (1995, p6-7). He also lists a series of conservation biology principles (some of which are useful aids to the reserve planning process) applicable to the maintenance of ecological integrity, including the following:

- Ecosystems are not only more complex than we think, but more complex than we can think (Egler 1977).

- The less data or more uncertainty involved, the more conservative a conservation plan must be (i.e., the more protection it must offer).

- Conservation biology is interdisciplinary, but biology must determine the bottom line (for instance, when conflicts with socioeconomic objectives occur).

- Species well distributed across their native range are less susceptible to extinction than species confined to small portions of their range.

- Large blocks of habitat, containing large populations of a target species, are superior to small blocks containing small populations.

- Blocks of habitat close together are better than blocks far apart (assuming no absolute barriers to dispersal lie between).

- Habitat in contiguous blocks is better than fragmented habitat.

- Interconnected blocks of habitat are better than isolated blocks.

- Blocks of habitat that are roadless or otherwise inaccessible to humans are better than roaded and accessible habitats.

- Conservation strategy must not treat all species as equal but must focus on species and habitats threatened by human activities (Diamond 1976).

- Maintaining viable ecosystems is usually more efficient, economical, and effective than a species-by-species approach.

- Biodiversity is not distributed randomly or uniformly across the landscape. In establishing protection priorities, focus on "hot spots" of high species richness, endemism, or other biological or ecological values.

- Ecosystem boundaries should be determined by reference to ecology, not politics.

- Because conservation value varies across a regional landscape, zoning is a useful approach to land use planning and reserve network design.

- Ecosystem health and integrity depend on the maintenance of ecological processes. 
- Human disturbances that mimic or simulate natural disturbances are less likely to threaten ecological integrity than are disturbances radically different from the natural regime.

- Ecosystem management requires cooperation between agencies and landowners and coordination of inventory, research, monitoring, and management activities.

- Management must be adaptive.

- Natural areas have a critical role to play as benchmarks or control areas for management experiments.

- "In the face of uncertainty over details, the prudent course is to risk erring on the side of protecting too much. Options for land conservation, once lost, cannot easily be regained" (Noss 1995, p4).

During the reserve design stage, consideration of the long-term maintenance of ecological integrity must take into account the threats posed by human activities "within, directly adjacent to, or between protected areas," since "it is well accepted that the integrity of a protected area becomes more difficult to maintain as the area surrounding it becomes less natural ...." "Roads and other forms of access within or between protected areas can lead to losses of large carnivores and other species sensitive to human exploitation or persecution." And ... "as sensitive species are lost from a reserve or network of reserves, ecological integrity declines" (Noss 1995, p6).

Finally, Noss $(1995, \mathrm{p} 63)$ points out that...

"Maintaining ecological integrity will seldom require complete exclusion of people over large areas. It is not so much people who need to be excluded from sensitive or biologically significant areas, but rather certain kinds of human activities activities such as logging, road-building, mining, oil drilling, intensive livestock grazing, off-road vehicle use, dam-building, and so on. In some areas, hunting, trapping, and fishing will need to be prohibited. Although even non-motorized, nonconsumptive recreationists can have damaging impacts when present in large numbers, in most cases access restrictions (no roads, limited trail systems) in core areas will keep these areas plenty wild."

\section{Challenges}

Given the scope and depth of the environmental changes that have occurred in the Grassland Natural Region of Alberta, it may not be possible to achieve adequate representation of natural landscapes and features within protected areas. The pressures from the cumulative impacts of human activities have taken their toll. Protection opportunities, in some cases, have been lost (e.g., extinct species). In other cases, it may require new management approaches and initiatives to ensure that no additional opportunities are lost. A major challenge in the prairies may well be the difficulty of maintaining, over the long term, a significantly large and contiguous land base within or outside of established protected areas, in which an area's biodiversity and associated natural ecological functions can continue. 
A continuing challenge will be to protect key elements of the grassland's biological diversity (e.g., species, critical and special habitats, biophysical features). Some species have extensive habitat requirements that will be difficult to capture within a network of protected areas.

Establishing "special places", however, can make a significant contribution to the conservation of species and maintenance of biodiversity. The establishment of protected areas that encompass critical habitats of key species would assist in the conservation of those species.

Protecting an adequate representation of an area's landscapes and features is just one part of protecting its biodiversity. As Grumbine (1992, p195) states, "there can be no biodiversityprotection network without a sustainable landscape of use as well." The landscape in which protected areas are "embedded" must also be used and conserved according to the principles of ecosystem-based management (e.g., Slocombe 1993; USDA 1993). As Grumbine expresses it, this will involve "both working with nature and letting it be; it is hands on as well as hands off."

Ecosystem-based management "does not presume to manage all components of the ecosystem, but rather to manage our activities so that overall ecosystem integrity is maintained, biodiversity is preserved and an ecologically sustainable flow of benefits is achieved." This "involves a shift in management focus from sustaining yields of competing resource outputs to sustaining ecosystems" (Bradley and Wallis 1996, p22). These authors present four key principles of ecosystem-based management for the prairies, namely:

- maintaining and restoring native prairie so society can derive and sustain all the benefits that flow from it (ecological, economic and social);

- attempting to perpetuate and approximate natural factors and processes;

- applying ecological knowledge to prairie management, monitoring the results and adapting as required; and

- recognizing multidisciplinary and interjurisdictional needs.

As Bradley and Wallis (ibid., p25) summarize,

"...adopting these principles of ecosystem-based management could have farreaching implications for how we manage and live in the prairie; indeed, it could affect how we think about and understand our place in the prairie ecosystem. It will reflect a shift in values away from controlling or living separate from our natural environment to respecting and living within it. Our decisions as individuals and communities in the prairie will determine how successful we are at managing our activities so that overall ecosystem integrity is maintained, biodiversity is preserved and an ecologically sustainable flow of benefits is achieved." 


\section{Chapter 2.2 Identifying the Gaps in the System of Protected Lands in Alberta}

\section{The Natural History Theme Approach}

The Natural History Theme approach is a three-level classification of the natural history features found within each of Alberta's 20 subregions. The features are sorted into Level 1,2 and 3 "Natural History Themes" [NHTs]. Level 1 NHTs are the broad, representative landscape types and patterns found within a subregion. They represent highly visible landform and ecosystem complexes, typically occupying more than $1 \%$ of the landscape. Level 1 NHTs can be further sub-divided into Level 2 and 3 NHTs. Level 2 NHTs are primarily the broad vegetation and habitat types characteristic of the subregion. Level 3 NHTs are generally localized features such as geologic outcrops, rock formations, plant communities, individual species and microhabitats for uncommon species (Alberta Environmental Protection [AEP] 1994b).

As part of the Special Places 2000 initiative, targets have been established for each of the Level 1 NHTs in each subregion (ibid.). These targets are a "best educated guess" on the amount of land $\left(\right.$ in $\mathrm{km}^{2}$ ) required to adequately represent the natural diversity contained within each NHT. It is assumed that a representative sample of the biophysical features will be protected if a representative portion of the landscapes in which they are found is protected.

Guidelines set out by AEP (ibid., p2) regarding the size and number of protected areas required to achieve adequate representation of Level 1 NHTs are as follows:

- unless a protected area is large relative to the size of the subregion, more than one area will be required to achieve adequate representation. These replicates serve to cover off some of the geographic variation within subregions.

- in addition to meeting the target area requirement, the NHT should be wellrepresented in more than $\mathbf{5}$ widely spaced small units meeting the minimum size criteria of $10 \mathrm{~km}^{2}$, or more than 2 widely spaced large units greatly exceeding the minimum size criteria.

These targets are only for protection objectives; they are "based on the assumption that lands specified for meeting those targets will have a prime function in ecosystem protection and will not be subject to significant recreation and tourism use" (ibid., p2).

According to the Canadian Environmental Advisory Council (1991) - as paraphrased in Report 3 (ibid., p2) - "Large wilderness areas in the order of $4000 \mathrm{~km}^{2}$ and larger are recommended for complete biodiversity and wilderness protection." Report 3 states: "Level 1 Theme targets indicate a desired area of protection that will be adequate to represent a considerable portion of Alberta's natural diversity - additional lands and management approaches are needed to adequately protect the full range of Alberta's natural diversity." 
The NHT system is a type of gap analysis; it provides a way of determining which features are not yet included or not adequately represented within existing protected areas. It also facilitates the comparison of sites within (but not between) subregions. This is important for evaluating and comparing areas for their potential contribution toward filling the gaps in the system of protected areas. Gap analyses have been completed for each of the province's natural regions for Level 1 NHTs (ibid., see Chapter 1 of that report). Gaps may be filled via the creation of new protected areas or, in some instances, by the expansion and/or reclassification of existing protected areas.

Lanscapes of the Grassland Natural Region have been significantly altered. It is one of the least protected regions in Alberta (ibid.). As Table 17 illustrates, less than $31 \%$ of the Level 1 NHT targets have been achieved for any of the grassland subregions. None of the targets have been achieved for the Mixedgrass Subregion and less than $8 \%$ has been achieved for the Foothills Fescue Subregion (Table 17).

Table 17. Areas, proportions and Level 1 Natural History Theme targets of the four grassland subregions (AEP 1994b).*

\begin{tabular}{|c|c|c|c|c|}
\hline Subregion & $\begin{array}{l}\text { Area }\left(\mathrm{km}^{2}\right) \text { of } \\
\text { subregion }\end{array}$ & $\begin{array}{c}\text { Area }\left(\mathrm{km}^{2}\right) \text { of Level } \\
1 \text { target }\end{array}$ & $\begin{array}{c}\% \text { of Level } 1 \\
\text { minimum target } \\
\text { achieved }\end{array}$ & $\begin{array}{c}\% \text { of subregion } \\
\text { protected }\end{array}$ \\
\hline Dry mixedgrass & 46976 & 1253 & 13.3 & 0.3 \\
\hline Foothills fescue & 14888 & 270 & 7.8 & 0.14 \\
\hline Northern fescue & 15385 & 448 & 31.1 & 1.04 \\
\hline Mixedgrass & 19177 & 263 & 0 & 0 \\
\hline
\end{tabular}

\section{Special Themes}

Special themes are included in the Level 1 NHT tables for each subregion "to ensure that all aspects of natural diversity are addressed" (Achuff and Wallis 1992, p6). Although they appear as Level 1 NHTs, they are generally not significant until Level 2 or 3 . Special themes "relate to features that are unique or atypical, characteristically occupying very limited areas of the landscape" (ibid.). Some, like the Milk River Ecosystem are significant at Level 1, but most include an "aggregation of 'atypical' or rare species and communities"(ibid.). Although several Special Themes are listed in the Level 1 NHT tables, "a detailed evaluation and identification of Special Themes has never been done for Alberta" (ibid.). Those identified for the grassland subregions are listed in Table 18. The focus of this report is achieving landscape representation through meeting targets for Level 1 NHTs. But, sites that include recognized Special Themes will be noted. 
Table 18. Examples of Special Themes in the Grassland Natural Region (after AEP 1994b).

\begin{tabular}{|c|c|c|}
\hline Subregion & Level 1 NHT & Level 2 NHT \\
\hline \multirow[t]{11}{*}{ Dry Mixedgrass } & \multirow[t]{6}{*}{ Milk River Ecosystem } & Eroding slope \\
\hline & & Sand plains \\
\hline & & Oxbow Lakes \\
\hline & & Milk River Canyon \\
\hline & & Igneous Dykes \\
\hline & & Police Coulee \\
\hline & \multirow[t]{5}{*}{ Other } & South Saskatchewan River Canyon \\
\hline & & Pakowki Lake \\
\hline & & Ice-thrust ridges \\
\hline & & Glacial streamlined terrain \\
\hline & & Glacial megablock \\
\hline \multirow{4}{*}{$\begin{array}{l}\text { Foothills } \\
\text { Fescue }\end{array}$} & \multirow[t]{4}{*}{ Other } & Sweetgrass Hills \\
\hline & & Milk River Ridge Unglaciated \\
\hline & & Belly Buttes \\
\hline & & Erratics Train \\
\hline \multirow{3}{*}{$\begin{array}{l}\text { Northern } \\
\text { Fescue }\end{array}$} & \multirow[t]{3}{*}{ Other } & Hand Hills \\
\hline & & Wintering Hills \\
\hline & & Ice-thrust Ridges \\
\hline Mixedgrass & Other & Red Rock Coulee \\
\hline
\end{tabular}

\section{Special Features}

To maintain the biodiversity of a natural region, it is necessary to identify and protect both the broad representative landscapes (i.e., Level 1 NHTs) as well as the smaller and more localized special features (e.g., the colonial bird nesting colonies on Lake Newell). It is important not only to achieve representation of Level 1 NHTs within established protected areas, but also to attempt to select those NHTs that have a diversity of high quality special features within them. Relying on landscape features alone may result in the omission or rare species and communities. 


\section{Enduring Features}

The Enduring Features approach is similar to the Alberta Natural History Theme approach. This is a gap analysis methodology used for the World Wildlife Fund Canada's "Endangered Spaces" campaign. A discussion on this approach follows as it is the approach used nationally and is comparable with the Alberta approach. It is based initially on mapping natural regions and identifying enduring features within them. An enduring feature is "a landscape element or unit characterized by relatively uniform origin and type of surficial deposits and topography" (Kavanagh et al. 1995).

As summarized in Alberta Environmental Protection (1996, p44):

"The use of enduring features . . . 'assumes that habitats defined by soils, parent materials, topography and other physical factors provide the appropriate framework to assess representation of landforms and their associated biotic features' (Noss 1995, p13). In addition, 'to capture biological diversity, the full array of physical habitats and environmental gradients associated with each enduring feature must be represented in protected areas' (Kavanagh et al. 1994, p34)...

'Once all enduring features of a given natural region are identified, comparison with the boundaries of existing protected areas reveals which features are not represented within the reserves network. As described by Kavanagh et al. (1995), 'These unrepresented enduring features are the 'gaps' in the system. A 'gap analysis', therefore, shows where there is insufficient protection of enduring features and ecological communities in existing protected-areas systems'."

An analysis of the ecological representation of enduring features within protected areas rated Alberta's Grassland Region as having "little or no representation" (WWF 1996). This level of representation is defined as follows: "None of the major enduring features are moderately or adequately captured and less than 80\% of features are partially captured" (ibid., p27). The 1996 analysis ( $i b i d$.) was done before Rumsey South and Ross Lake natural areas were established.

The addition of Ross Lake would likely not have changed the representation measure for the Foothills Fescue Subregion. Although it is a significant site, it is small and includes primarily special features and themes. Rumsey South, however, has made significant contributions to the protection of enduring features in the Northern Fescue Subregion. Its designation likely increases the representation measure to "partially represented." This category, "partially represented" is measured as "Either up to $50 \%$ of the major enduring features are either moderately or adequately captured and at least $50 \%$ of the remaining features are at least partially captured; or a significant majority (at least $80 \%$ ) of all features are partially captured" (ibid., p27).

The Enduring Feature's methodology is based on "the assumption that ecological diversity (and hence, biodiversity) is largely an expression of abiotic factors such as climate, physiography, topography, and surface geology interacting over time." Level 1 NHTs are also primarily landscape types; however, they consist of a "complex of physical and biological features" (Achuff 1992, p5). An important difference then between the Level 1 NHTs and the Enduring Features is that Level 1 NHTs include a consideration of the biotic component. 
Another difference is that of scale. Enduring features are groupings of soil polygons from the Soil Landscapes of Canada digital database mapped at a scale of 1:1,000,000 (AAFC 1995). Level 1 NHTs are defined based on available data. This often includes the use of surficial geology maps, soil maps and aerial photography. Scales vary, but are generally 1:250,000 or larger. Because both systems look generally at landscape features, there are similarities between the Level 1 NHTs and the soil landscape polygons. The soil polygons, however, are mapped at a coarser scale than the Level 1 NHTs. For example, Valley/Ridge areas can be easily identified from a map, but specific Level 1 NHTs for that category (exposed and protected slope, springs and floor/stream) cannot be identified. In addition, two themes may be grouped within a single polygon as dominant and subdominant soil landscapes, making it difficult or impossible to differentiate them.

The two methodologies, although not entirely comparable, are compatible. The Level 1 NHTs that are primarily abiotic (landscape and soils), match with the enduring features. One example is the dune field at Middle Sand Hills. Themes like springs, however, that were given Level 1 NHT status due primarily to their biotic importance, are embedded within enduring features.

According to Kavanagh (op. cit., p47), enduring features are assessed for their level of representation based on:

- the spatial extent, pattern, variability and distribution of each enduring feature in a natural region,

- the extent that the enduring feature is captured within existing protected areas,

- the long-term security afforded the enduring feature by the existing protected area legal designation, and

- characteristics (size and frequency) of important disturbance-recovery cycles.

The WWF approach "intentionally moves away from an emphasis on percentage as a criterion for representation in order to focus on natural processes" (Kavanagh et al. 1995, p47). The example given is that for some community types, "a larger area would be required to maintain the range of ... community variation and associated disturbance regimes" (ibid., p47). Although measurable size targets were set for Level 1 NHTs, the differences in the various communities were considered. Targets were set based on "the importance of various Themes to natural diversity representation as well as the areal extent of those Themes in the landscape of each subregion" (Achuff 1992, p8). WWF, while stressing that "ecological representation, not percentage, is the Endangered Spaces Campaign goal," notes that achieving the goal to protect "...a representative sample of each of the country's terrestrial natural regions....will likely involve setting aside at least $12 \%$ of Canada's lands" (WWF 1996, p24).

\section{Existing Protected Areas in the Grassland Natural Region}

"Protected Areas" are defined by Alberta Environmental Protection as sites that are "explicitly legislated and managed to protect important natural features" (AEP 1994b). These sites include crown lands that are established as national parks, national wildlife areas, wilderness areas, 
wilderness parks, ecological reserves, provincial parks and natural areas. The protected areas established within the Grassland Natural Region are listed in Table 19. As noted in the table, some sites straddle subregion borders, and so only a portion of the site falls within a particular subregion. Also, several sites are smaller than the minimum size criteria of $10 \mathrm{~km}^{2}$ for contributing to representation of Level 1 NHTs. Report 3, Table A.18 lists Waterton Lakes National Park and Cypress Hills Provincial Park as occurring in the Grasslands Natural Region (AEP 1994b). Due to refinements in the natural region boundaries, both sites are now considered outside this region (Achuff, pers. comm.), and are not included in any of the analyses done for this report.

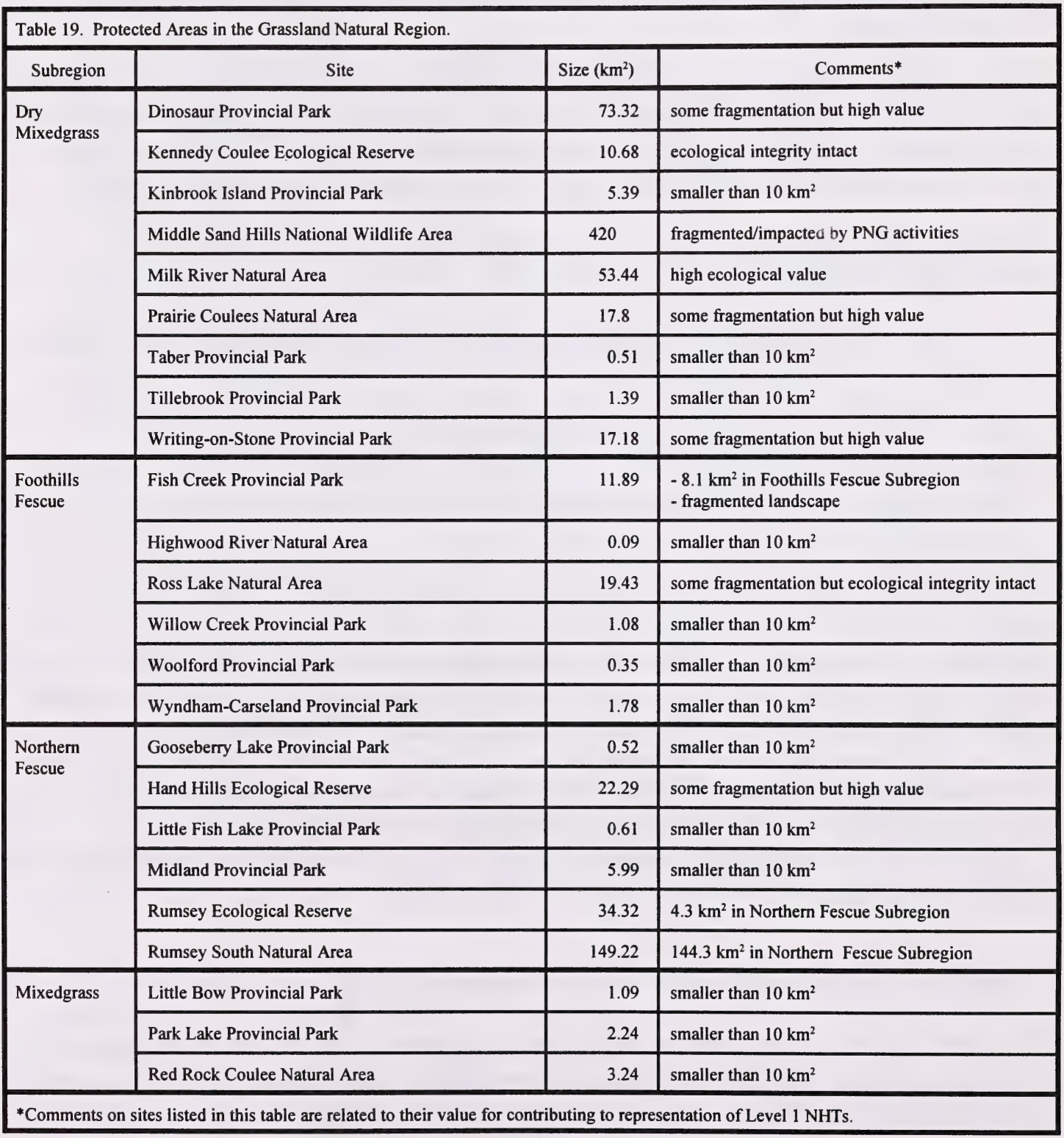




\section{Representation of Level 1 Natural History Themes in Existing Protected Areas}

In Alberta Protected Areas Systems Analysis, Report 3 (AEP, 1994b), the estimated aerial extent of Level 1 NHTs (in $\mathrm{km}^{2}$ ) is presented for existing protected areas within each of the four grassland subregions. Those aerial extent figures, however, were based on the entire land base of each protected area. Developments such as parking lots, roads or townsites were included and counted as contributing to protection targets in these initial estimates, when clearly they do not.

For this report, estimates of the Level 1 NHTs targets within established protected areas have been revised to exclude developments and associated impacted areas. Sites with an area of less than $10 \mathrm{~km}^{2}$ were not evaluated since they do not make significant contributions to the protection of representative landscapes. They may, however, protect significant Level 2 or Level 3 NHTs (e.g., the colonial nesting bird colonies at Kinbrook Island Provincial Park). The following discussion briefly outlines the extent to which the Level 1 NHTs are represented and the major gaps remaining in each of the grassland subregions.

\subsection{Dry Mixedgrass Subregion}

\section{Representation within existing protected areas:}

Five protected areas greater than $10 \mathrm{~km}^{2}$ are located within the Dry Mixedgrass Subregion Dinosaur Provincial Park, the Milk River Natural Area/Kennedy Coulee Ecological Reserve complex, the Middle Sand Hills National Wildlife Area (NWA), Writing-On-Stone Provincial Park and Prairie Coulees Natural Area. Together, these sites contribute to meeting an average of about $13 \%$ (range $=0 \%$ to $100 \%$ ) of the Level 1 NHT targets for this subregion (Table 20 ).

Although the Middle Sand Hills NWA includes a large land base $\left(420 \mathrm{~km}^{2}\right)$, its road network and high density of wellsites and other PNG facilities substantially fragment the area (Map 6). This likely reduces its ecological integrity to the point where it should not be considered as contributing to representation of Level 1 NHTs (Table 20). Facility infrastructures within Dinosaur, Writing-On-Stone and Prairie Coulees also do not contribute to representation of Level 1 NHTs and the "amount protected" figures were adjusted accordingly. The Milk River Natural Area/Kennedy Coulee Ecological Reserve has few developments within its boundaries, and the "amount protected" figures reflect this situation.

The targets have been met for one of the thirteen Level 1 NHTs — the Valley/Ridge: protected slope theme. One other NHT has more than $50 \%$ of its Level 1 target achieved - the Valley/Ridge: exposed slope theme (58\%). The remaining eleven Level 1 NHTs have less than $30 \%$ of their targets achieved and, of those, three have no representation (Table 20). 


\section{Gaps to be filled:}

In the Dry Mixedgrass Subregion, there are major gaps to be filled to meet Level 1 NHT targets since most of those targets have not been met. All of the Level 1 NHT representation comes from sites located in the southern portion of the subregion. There is no representation from the northern portion. Within this subregion, there is no representation for three NHTs - Sandy Upland: dune field, Wetland: deep marsh, and Wetland: alkali wetland (Table 20). To meet the target of at least $1252 \mathrm{~km}^{2}$ for this subregion, an additional minimum of $1085 \mathrm{~km}^{2}$ of land, containing representation of 13 Natural History Themes, is required (Table 20).

\subsection{Foothills Fescue Subregion}

\section{Representation within existing protected areas:}

There are two protected areas greater than $10 \mathrm{~km}^{2}$ in size and have at least a major portion of their area within the Foothills Fescue Subregion - Fish Creek Provincial Park and Ross Lake Natural Area. Eight $\mathrm{km}^{2}(68 \%)$ of Fish Creek is within the subregion. Fish Creek is a developed urban park and is fragmented by trails, parking lots, day-use areas, etc. Once developments were excluded, about $2.2 \mathrm{~km}^{2}$ of the park contributes to representation of Level 1 NHTs. Fish Creek and Ross Lake contribute to seven of the 12 Level 1 NHTs. An average contribution of about $7.8 \%$ (range $=0 \%$ to $62 \%$ ) of the Level 1 targets for this subregion have been met (Table 21). About $0.14 \%$ of the subregion is within these two protected areas. The Level 1 NHTs best represented are the Valley/Ridge: exposed slope (62\%) and the Valley/Ridge: protected slope (49\%).

\section{Gaps to be filled:}

There are major gaps in the Level 1 NHT representation for this subregion. No targets have been achieved. Four Level 1 NHTs have no representation - Non-Sandy Upland: glacial lake bed, Non-Sandy Upland: ground moraine, Sandy Upland: sandy plain and Wetland: deep marsh. Less than $10 \%$ of the minimum targets have been achieved for four other Level 1 NHTs. To meet the target of at least $270 \mathrm{~km}^{2}$ for this subregion, an additional $249 \mathrm{~km}^{2}$ of land, containing representation of 12 Level 1 NHTs, is required (Table 21).

\subsection{Northern Fescue Subregion}

\section{Representation within existing protected areas:}

The Northern Fescue Subregion has two protected areas greater than $10 \mathrm{~km}^{2}$ in size within its boundaries - Hand Hills Ecological Reserve and Rumsey South Natural Area. Some development (i.e., PNG facilities, access roads) occurs in both sites and the "amount protected" figures have been adjusted accordingly (Table 22). 


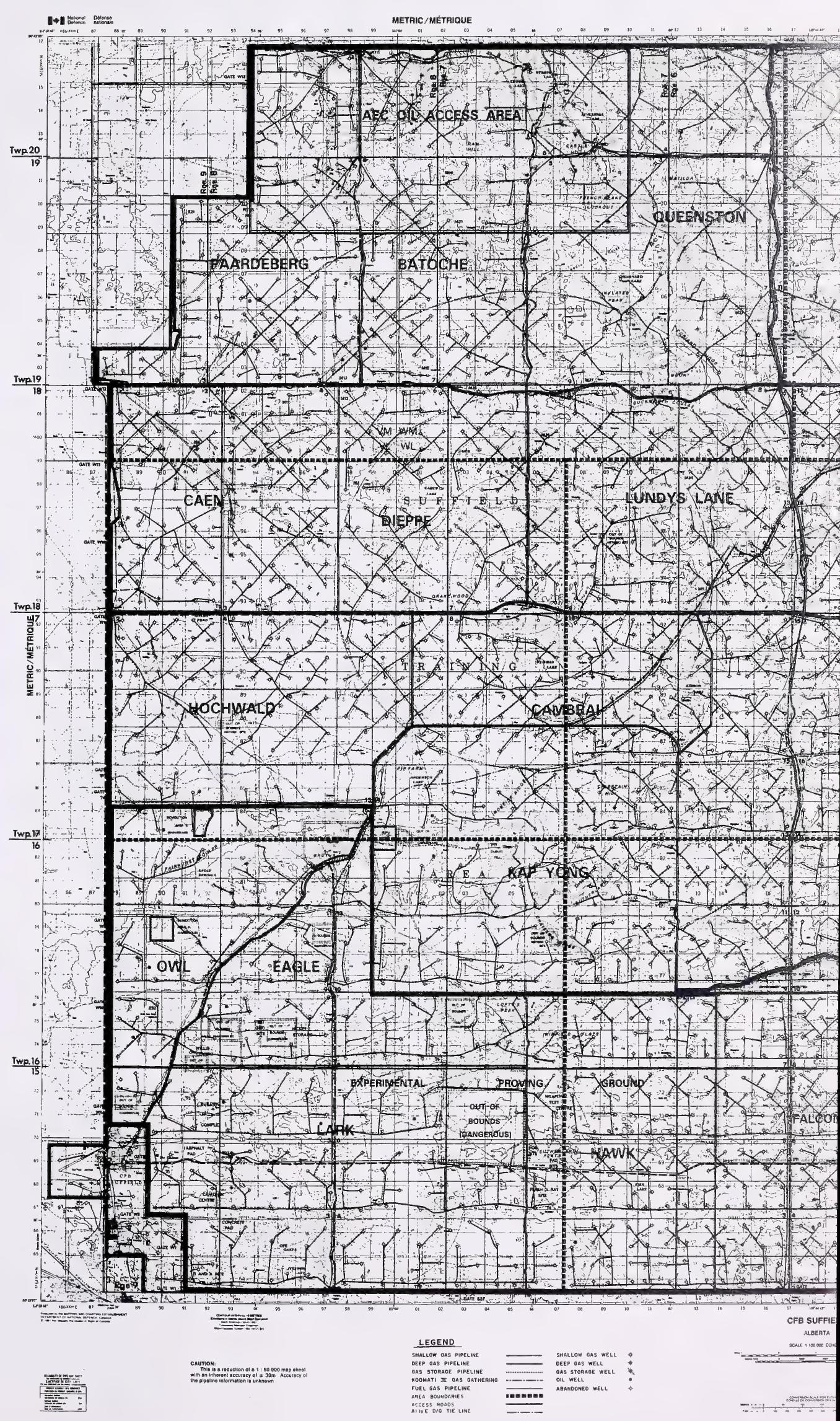


The Hand Hills Ecological Reserve and Rumsey South Natural Area contribute to meeting an average of about $31 \%$ (range $=0 \%$ to $100 \%$ ) of the Level 1 NHT targets for this subregion and make up about $1.04 \%$ of the subregion's total area (Table 22). The targets for three of the Level 1 NHTs have been met - Non-Sandy Upland: hummocky moraine, Wetland: wet meadow and Wetland: shallow marsh. Two other NHTs have nearly $75 \%$ of their targets met - Wetland: deep marsh and Wetland: alkali wetland.

\section{Gaps to be filled:}

There is no representation of two Level 1 NHTs - Non-Sandy Upland: glacial lake bed and Sandy Upland: dune field. Six others are less than 10\% represented. The existing protected areas are located at the western and south-western sides of the subregion. Additional Level 1 NHT representation is still required to cover the biophysical variation across the subregion. To meet the target of at least $447 \mathrm{~km}^{2}$ for this subregion, an additional $308 \mathrm{~km}^{2}$ of land, containing representation of 11 Level 1 NHTs, is required (Table 22).

\subsection{Mixedgrass Subregion}

\section{Representation within existing protected areas:}

Of the four subregions in the Grassland Natural Region, the Mixedgrass Subregion has the least representation of Level 1 NHTs. There are three protected areas within this subregion - Little Bow Provincial Park, Park Lake Provincial Park and Red Rock Coulee Natural Area. None, however, meet the minimum size criteria of $10 \mathrm{~km}^{2}$ for Level 1 NHT evaluation. As a result, there are no protected areas within this subregion that contribute to representation of Level 1 NHTs and no Level 1 NHT targets have been filled (Table 23). These sites do, however, contribute to representation of "special features" and "special themes" (Red Rock Coulee), or to recreation and heritage appreciation objectives.

\section{Gaps to be filled:}

All Level 1 NHTs remain to be filled (Table 23). A target of at least $262 \mathrm{~km}^{2}$ of land, containing representation of 13 Level 1 NHTs, within blocks exceeding $10 \mathrm{~km}^{2}$ has been identified for this subregion. This represents $1.37 \%$ of the total area of the subregion (Table 23). 

The Hand Hills Ecological Reserve and Rumsey South Natural Area contribute to meeting an average of about $31 \%$ (range $=0 \%$ to $100 \%$ ) of the Level 1 NHT targets for this subregion and make up about $1.04 \%$ of the subregion's total area (Table 22). The targets for three of the Level 1 NHTs have been met - Non-Sandy Upland: hummocky moraine, Wetland: wet meadow and Wetland: shallow marsh. Two other NHTs have nearly $75 \%$ of their targets met - Wetland: deep marsh and Wetland: alkali wetland.

\section{Gaps to be filled:}

There is no representation of two Level 1 NHTs - Non-Sandy Upland: glacial lake bed and Sandy Upland: dune field. Six others are less than $10 \%$ represented. The existing protected areas are located at the western and south-western sides of the subregion. Additional Level 1 NHT representation is still required to cover the biophysical variation across the subregion. To meet the target of at least $447 \mathrm{~km}^{2}$ for this subregion, an additional $308 \mathrm{~km}^{2}$ of land, containing representation of 11 Level 1 NHTs, is required (Table 22).

\subsection{Mixedgrass Subregion}

\section{Representation within existing protected areas:}

Of the four subregions in the Grassland Natural Region, the Mixedgrass Subregion has the least representation of Level 1 NHTs. There are three protected areas within this subregion - Little Bow Provincial Park, Park Lake Provincial Park and Red Rock Coulee Natural Area. None, however, meet the minimum size criteria of $10 \mathrm{~km}^{2}$ for Level 1 NHT evaluation. As a result, there are no protected areas within this subregion that contribute to representation of Level 1 NHTs and no Level 1 NHT targets have been filled (Table 23). These sites do, however, contribute to representation of "special features" and "special themes" (Red Rock Coulee), or to recreation and heritage appreciation objectives.

\section{Gaps to be filled:}

All Level 1 NHTs remain to be filled (Table 23). A target of at least $262 \mathrm{~km}^{2}$ of land, containing representation of 13 Level 1 NHTs, within blocks exceeding $10 \mathrm{~km}^{2}$ has been identified for this subregion. This represents $1.37 \%$ of the total area of the subregion (Table 23). 


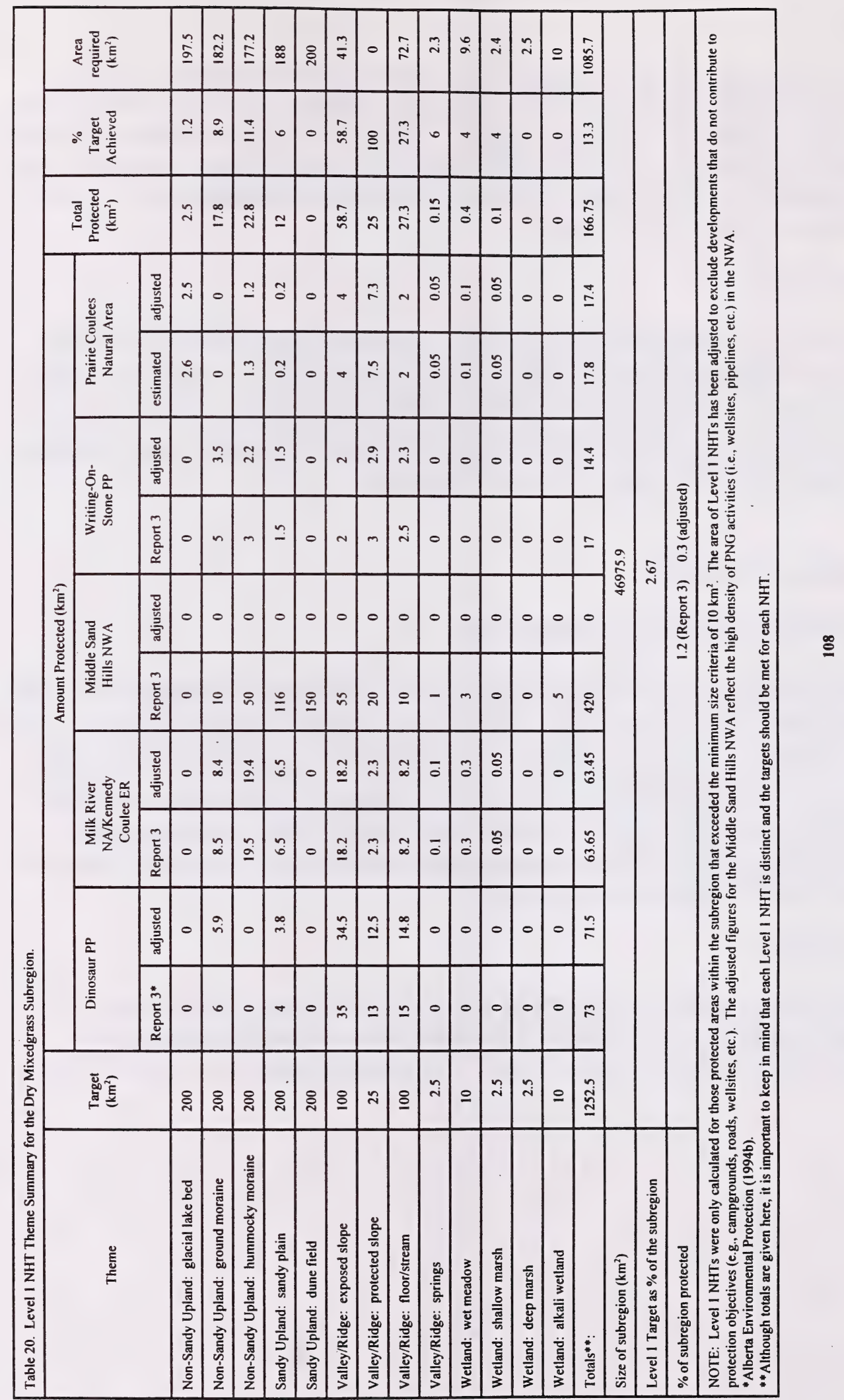




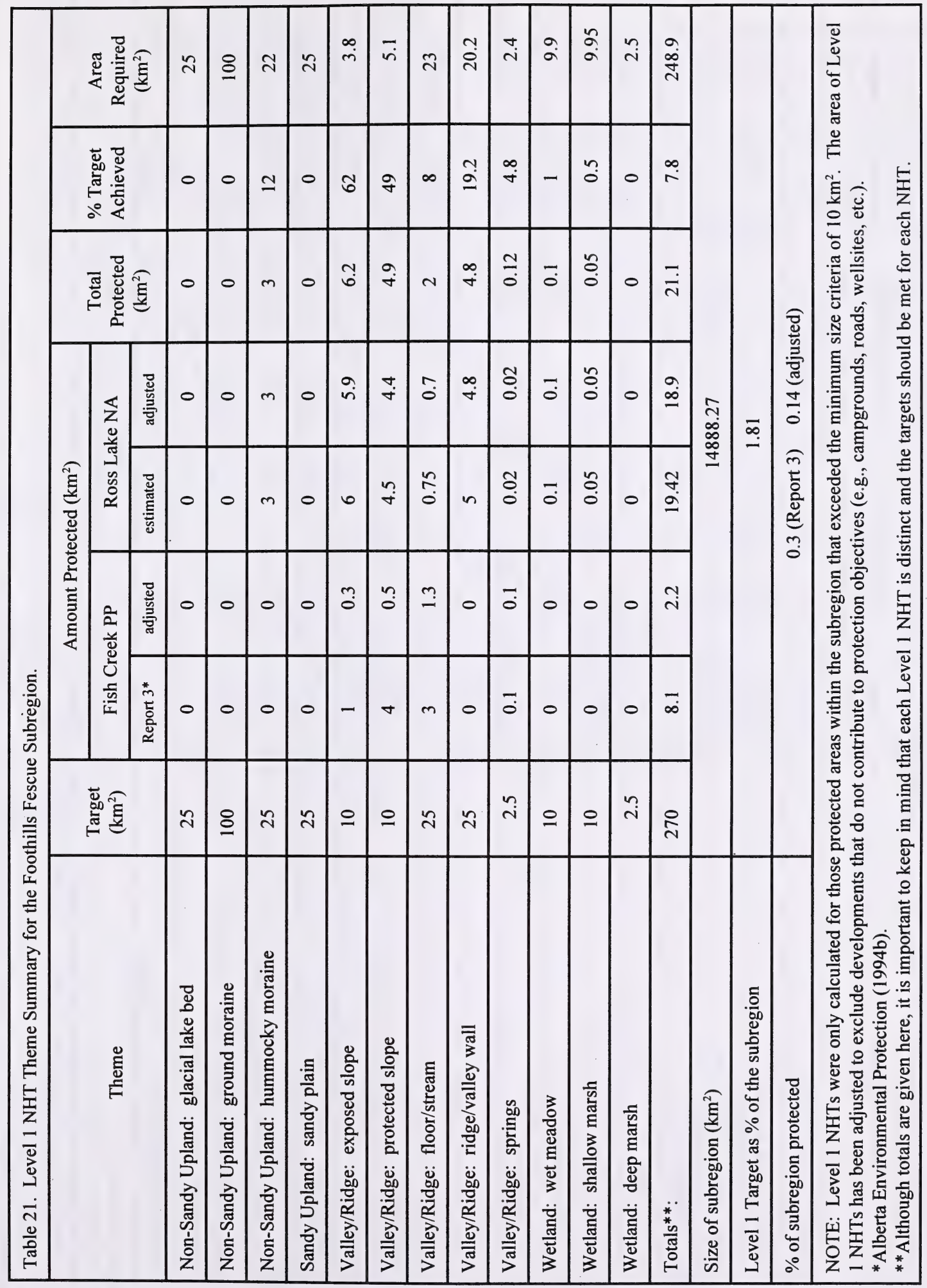




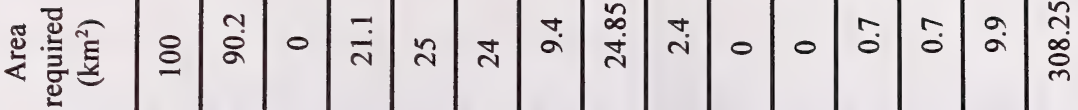

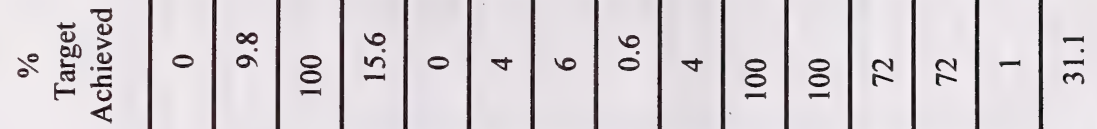

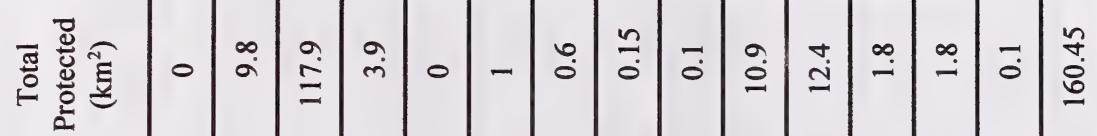

|

蒙

च

㲾

ฮ

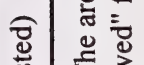

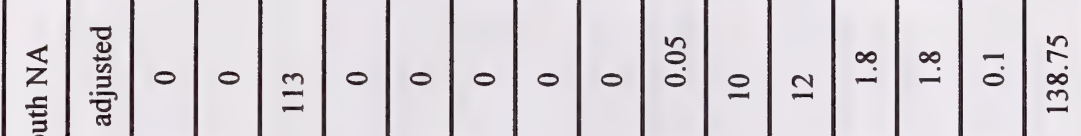

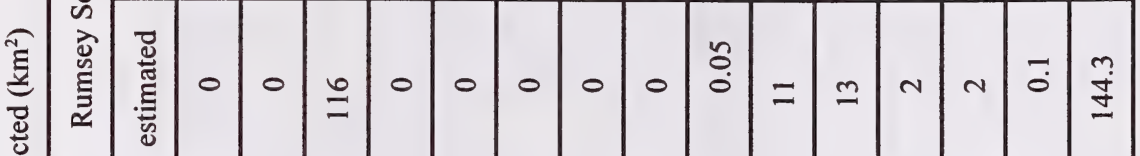

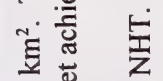

엉응

ก 뜬

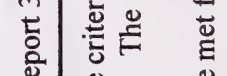

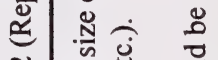

กั

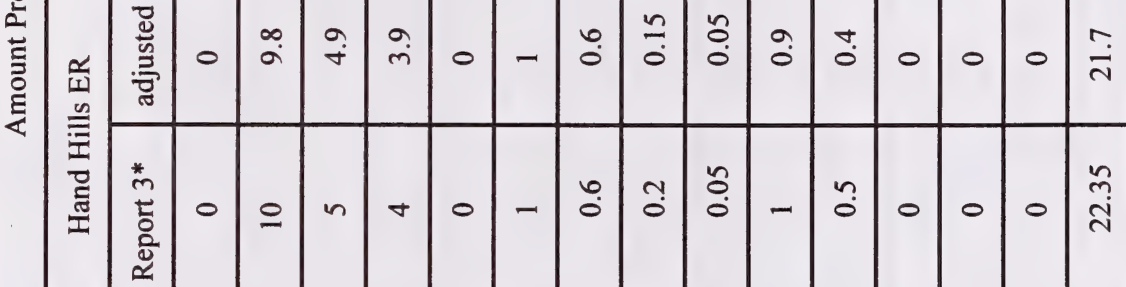

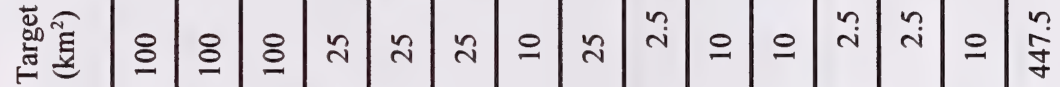




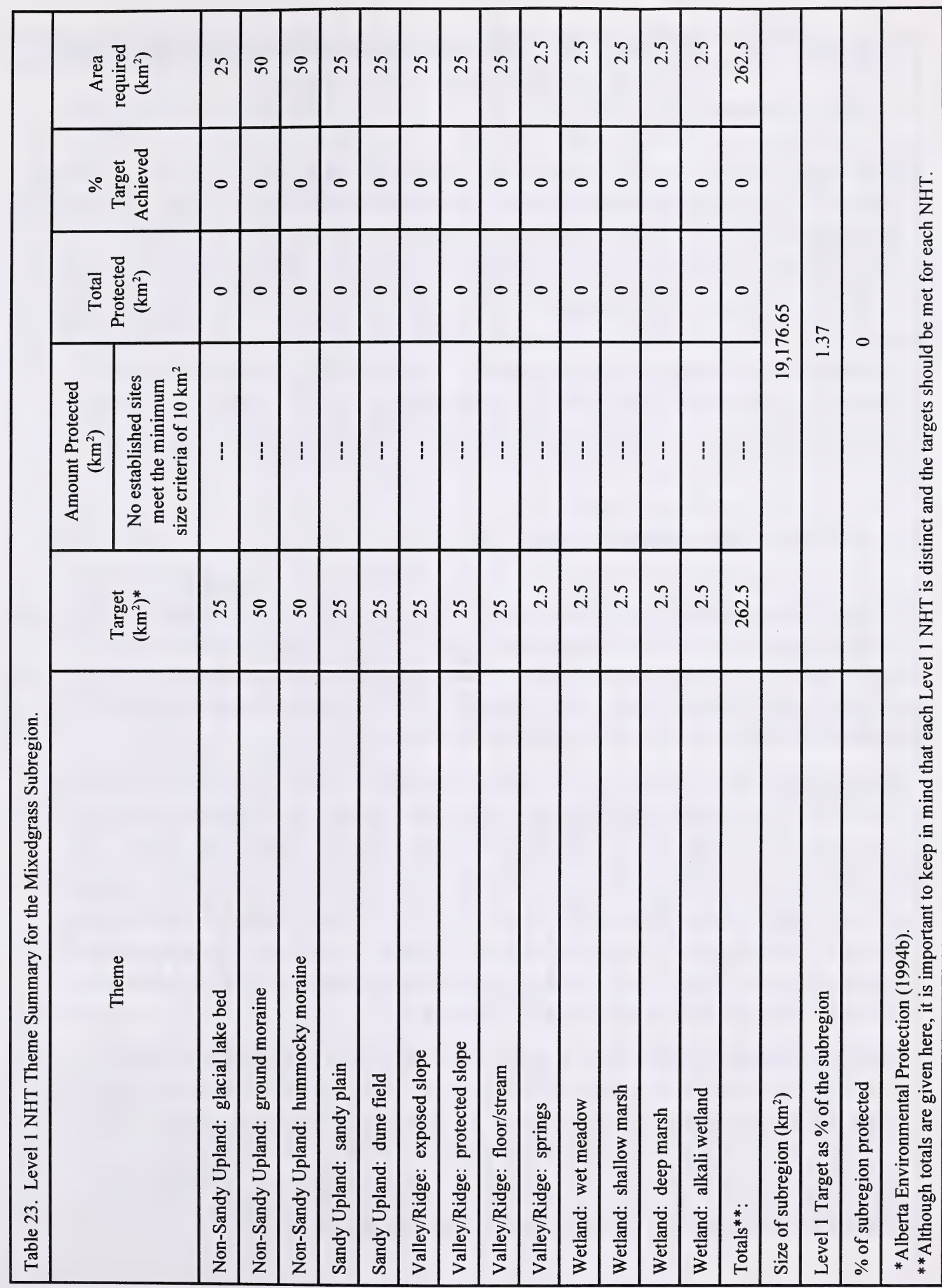




\section{Chapter 2.3 Filling the Gaps in the System of Protected Lands in Alberta's Grasslands}

Once the gaps in the system of protected areas are identified, the next step is to find sites to fill those gaps. In the Grassland Natural Region, most of the Level 1 Natural History Theme targets have yet to be achieved. To help focus on areas that have the potential to contribute to representation of missing themes, there are several studies and sources of information available. These include Environmentally Significant Area (ESA) studies and digital databases, the Soil Landscapes of Canada database (Shields and Lindsay, 1990), a number of overview biophysical studies (e.g., Wallis and Wershler 1988), and interpretation of National Topographic Series and Surficial Geology maps and aerial photographs. The current focus is towards achieving landscape representation through meeting targets for Level 1 NHT, however, relying on landscape features alone may result in the omission of rare species and communities. Any known special features or special themes are therefore noted throughout the discussions.

\section{Environmentally Significant Areas}

Bentz et al. (1995, p6) define ESAs as: "landscape elements or places which are vital to the long-term maintenance of biological diversity, soil, water or other natural processes, both on-site and in a regional context." They also characterize ESAs as "important, unique and often sensitive features of the landscape." ESAs include features such as critical wildlife habitats, rare and endangered flora and fauna, unique geological or physiographic features, representative landscapes and remnants of formerly intact ecosystems.

Several studies have been conducted within the Grassland Natural Region that identify ESAs (Table 24). These studies were originally intended as planning tools for municipal governments. In total, these studies have identified 137 ESAs of provincial and higher significance within the Grassland Natural Region (Table 25). Of these, 22 are internationally significant, 35 nationally significant and 80 provincially significant. Those ESAs of provincial and higher significance occupy a combined area of about $20352 \mathrm{~km}^{2}$ or about $21 \%$ of the Grassland Natural Region (Table 25). The largest ESAs range in size from $348 \mathrm{~km}^{2}$ to $1730 \mathrm{~km}^{2}$. The ESAs within the Dry Mixedgrass Subregion have the largest average size $\left(\right.$ mean $\left.=197 \mathrm{~km}^{2}\right)$; the Foothills Fescue Subregion has the smallest $\left(\right.$ mean $\left.=59 \mathrm{~km}^{2}\right)$.

Most ESAs contain special features and special themes. Many of these are listed in the following four chapters under each of the sites that are discussed. Some sites have been more intensively studied than others and, therefore, the lists vary in their completeness. These lists will aid in selecting sites that are recognized for their diversity. Although a number of special features are located within established protected areas, many are not. Additional lands and different management approaches may, therefore, be required to adequately protect these features, or existing protected area boundaries may need to be modified. 
Table 24. Environmentally Significant Areas Studies in the Grassland Natural Region

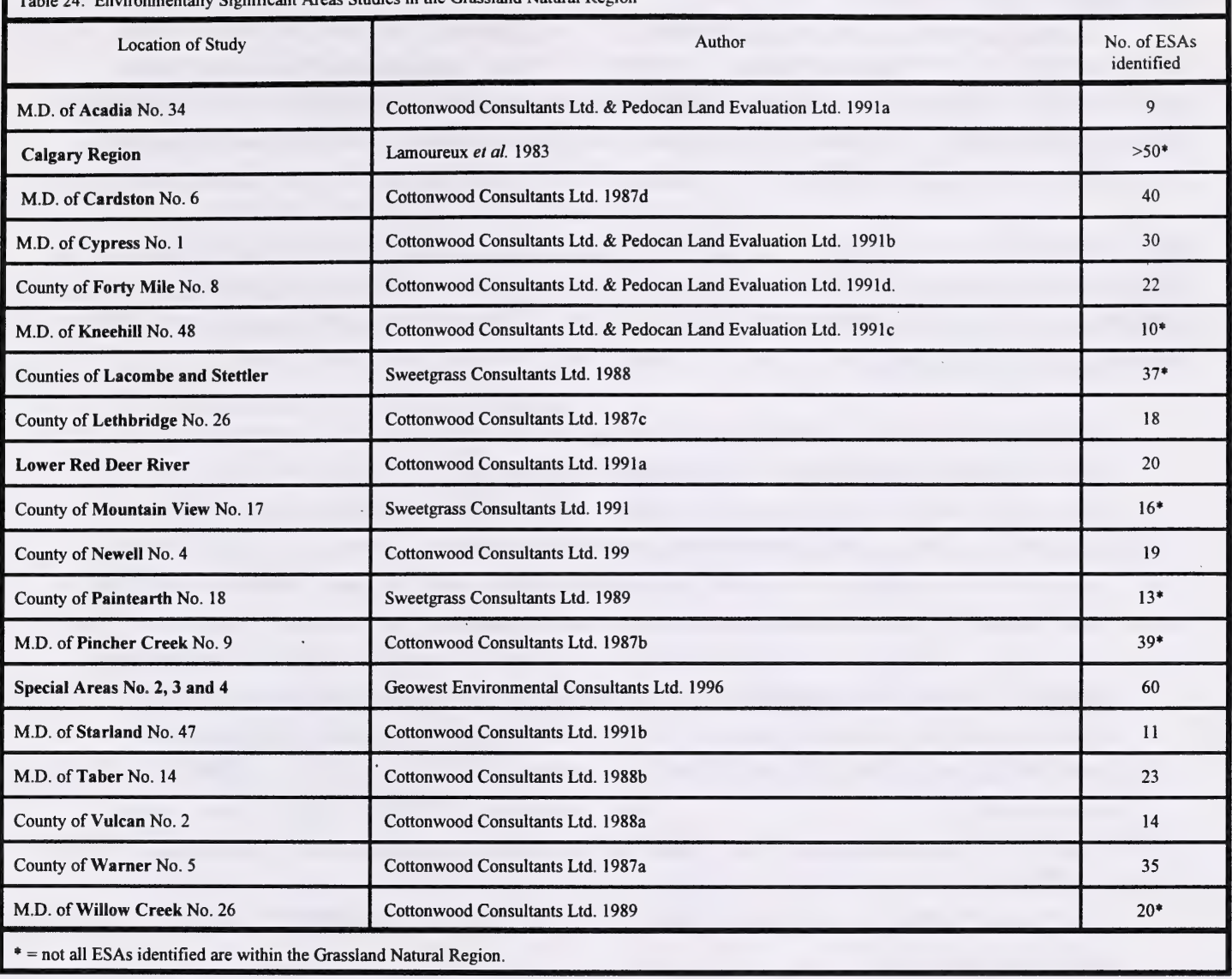

Table 25. Distribution, aerial extent and significance ratings of ESAs within the Grassland Natural Region (ANHIC 1996a, 1997).

\begin{tabular}{|c|c|c|c|c|c|c|c|c|c|c|}
\hline \multirow{2}{*}{$\begin{array}{l}\text { ESA } \\
\text { Significance Rating }\end{array}$} & \multicolumn{2}{|c|}{ Dry Mixedgrass } & \multicolumn{2}{|c|}{ Foothills Fescue } & \multicolumn{2}{|c|}{ Northern Fescue } & \multicolumn{2}{|c|}{ Mixedgrass } & \multicolumn{2}{|c|}{ Total } \\
\hline & $\begin{array}{c}\text { Size } \\
\left(\mathrm{km}^{2}\right)\end{array}$ & $\begin{array}{l}\text { No. } \\
\text { ESAs }\end{array}$ & $\begin{array}{c}\text { Size } \\
\left(\mathrm{km}^{2}\right)\end{array}$ & $\begin{array}{l}\text { No. } \\
\text { ESAs }\end{array}$ & $\begin{array}{c}\text { Size } \\
\left(\mathrm{km}^{2}\right)\end{array}$ & $\begin{array}{l}\text { No. } \\
\text { ESAs }\end{array}$ & $\begin{array}{c}\text { Size } \\
\left(\mathrm{km}^{2}\right)\end{array}$ & $\begin{array}{l}\text { No. } \\
\text { ESAs }\end{array}$ & $\begin{array}{c}\text { Size } \\
\left(\mathrm{km}^{2}\right)\end{array}$ & $\begin{array}{l}\text { No. } \\
\text { ESAs }\end{array}$ \\
\hline International & 641 & 6 & 17 & 2 & 781 & 9 & 84 & 8 & 1523 & 22 \\
\hline National & 5701 & 18 & 177 & 7 & 903 & 7 & 813 & 12 & 7594 & 35 \\
\hline Provincial & 6848 & 43 & 1345 & 17 & 1259 & 19 & 1783 & 24 & 11235 & 80 \\
\hline Total & 13190 & 67 & 1539 & 26 & 2943 & 35 & 2680 & 44 & 20352 & 137 \\
\hline Subregion size $\left(\mathrm{km}^{2}\right)$ & \multicolumn{2}{|c|}{$46,975.90$} & \multicolumn{2}{|c|}{$14,888.27$} & \multicolumn{2}{|c|}{$15,384.61$} & \multicolumn{2}{|c|}{$19,176.65$} & \multicolumn{2}{|c|}{$96,425.43$} \\
\hline $\begin{array}{l}\text { Proportion of subregion } \\
\text { occupied by ESAs }(\%)^{*}\end{array}$ & \multicolumn{2}{|c|}{28.1} & \multicolumn{2}{|c|}{10.3} & \multicolumn{2}{|c|}{19.1} & \multicolumn{2}{|c|}{13.9} & \multicolumn{2}{|c|}{21.1} \\
\hline $\begin{array}{l}\text { Mean size of ESAs } \\
\left(\mathrm{km}^{2}\right)^{*}\end{array}$ & \multicolumn{2}{|c|}{197} & \multicolumn{2}{|c|}{59} & \multicolumn{2}{|c|}{84} & \multicolumn{2}{|c|}{61} & \multicolumn{2}{|c|}{148} \\
\hline Largest ESA $\left(\mathrm{km}^{2}\right)^{*}$ & \multicolumn{2}{|c|}{1632} & \multicolumn{2}{|c|}{430} & \multicolumn{2}{|c|}{348} & \multicolumn{2}{|c|}{399} & \multicolumn{2}{|c|}{$1730 * *$} \\
\hline
\end{tabular}




\section{Digital Coverages}

Given the level of development in the Grasslands Natural Region, an important step in identifying the best potential protected areas in the region involved what could be termed an "inverse gap analysis" (i.e., determining what is left). On a subregion by subregion basis, potential sites were identified by screening to ensure that criteria, as listed below, were met.

Only provincial crown and mixed lands (i.e., these are both crown and private lands as undifferentiated on the quarter section digital coverage) were considered as having potential to contribute to a provincially-legislated protected area. These were determined by $\underline{\text { land }}$ ownership digital coverage:

- Provides information on the distribution of private, provincial crown and federal crown land (e.g., Indian reserves, CFB Suffield) in the area.

- Derived by combining a quarter-section ARC/INFO GIS positional file for Alberta (accuracy to $5 \mathrm{~m}$ ) with land ownership attribute data.

- Land ownership attribute data is by quarter-section from LSAS. The Land Status Automated System is the official government database of the status of lands in Alberta including township information and any dispositions registered against those lands.

- Accurately identifies quarter-sections that are entirely crown or entirely freehold.

- Quarter-sections listed as "mixed" may be almost entirely crown, almost entirely freehold or some combination. Further queries of LSAS would be required to learn their exact status.

- Quarter-sections listed as "other" had an unknown ownership status at the time of the LSAS data exchange.

- The "water" areas are all waterbodies $1.5 \mathrm{~km}^{2}$ or larger as taken from 1:250,000 map data hydrology coverage.

Urban developments were excluded from consideration as having potential to contribute to representation of Level 1 NHTs. These were determined by cities and towns digital coverage:

- Derived by converting digital 1:250,000 scale Provincial Mapping Series (Microstation Files) to ARC/INFO GIS format

High road densities decrease the quality of a site for its contribution to representation of Level 1 NHTs. These were determined by road digital coverage:

- Derived by converting digital 1:250,000 scale Provincial Mapping Series (Microstation Files) to ARC/INFO GIS format.

- Road densities derived by intersecting the road network with townships and subregions.

- Road data was then summarized by unique township/subregion polygons and densities calculated. 
High densities of wellsites decrease the quality of a site for its contribution to representation of NHTs. These were determined by petroleum and natural gas wellsite digital coverage:

- Provides information on the distribution and density of wellsites in an area.

- Point data supplied by Alberta Energy and converted to ARC/INFO GIS format.

- Data shows bottom-hole location, which is usually but not always the same as the surface wellsite location (i.e., non-deviated boreholes).

- Includes all wells on record (i.e., dry, producing, abandoned, etc.).

Areas with more than $50 \%$ remaining in native prairie were considered to be of more value for their contribution to representation of NHTs than sites with less than $50 \%$. These were determined by native prairie digital coverage:

- Provides information, at either a quarter-section scale or a township scale, on the proportion of native prairie in an area.

- Original quarter-section data supplied by Resource Data Division of the Department of Environmental Protection.

- Derived by converting digital quarter-section design files to ARC/INFO GIS format (positional accuracy to $5 \mathrm{~m}$ ).

- Does not cover any one subregion completely and does not cover the Northern Fescue Subregion at all.

- Native prairie coverage (township accuracy) was derived by linking a dBase data file to an ARC/INFO GIS township positional file.

- The dBase file was created by using township coverage generated by ERCB (1992).

- Since one value for native prairie was assigned to an entire township, the value is only an estimate.

ESAs ranked as provincially, nationally or internationally significant were considered as having potential, as determined by $\underline{E} \boldsymbol{S A}$ digital coverage:

- Compiled from the series of ESA reports done for the province

- Digitized from the original report maps, with scales generally between 1:50,000 and $1: 250,000$

- Ranking and criteria have evolved since the first ESA study in Alberta was done for the Calgary region (Lamourex et al. 1983)

- Digital data and rankings were updated for those ESAs ranked as provincially, nationally or internationally significant (ANHIC 1997).

Using combinations of the digital coverages listed above, each grassland subregion was evaluated to identify sites that are of the most value for conservation. Only sites on provincial crown land and mixed land (because of the provincial crown component) were considered as potential protected areas. These are the only lands available for inclusion in the provinciallylegislated protected area's network. The results of this process are presented for each of the grassland subregions in the following four chapters. 


\section{Chapter 2.4 Filling the Gaps in the Dry Mixedgrass Subregion}

\section{Size and Land Ownership}

- This is the largest of the four grassland subregions, totalling about $47,000 \mathrm{~km}^{2}$.

- Approximately one-half $\left(51 \%\right.$ or $\left.23774 \mathrm{~km}^{2}\right)$ of the subregion is privately owned (Table 26$)$.

- The Eastern Irrigation District owns large blocks of land in the Brooks area.

- About $42 \%\left(19896 \mathrm{~km}^{2}\right)$ of the subregion is crown land; $36.7 \%\left(17194 \mathrm{~km}^{2}\right)$ provincially owned and $5.7 \%\left(2702 \mathrm{~km}^{2}\right)$ federally owned (Table 26$)$.

- Large blocks of provincial crown land are located adjacent to Canadian Forces Base Suffield and between the Red Deer River and Highway 9 and south of Cypress Hills Provincial Park.

- About $7 \%\left(3232 \mathrm{~km}^{2}\right)$ of the lands in the subregion are categorized as "mixed" ownership $\left(1042 \mathrm{~km}^{2}\right)$, "other" $\left(1689 \mathrm{~km}^{2}\right)$ and "water" $\left(501 \mathrm{~km}^{2}\right)$, as shown in Table 26.

Table 26. Land ownership within the Dry Mixedgrass Subregion.

\begin{tabular}{|c|c|c|}
\hline Category & Land area $\left(\mathrm{km}^{2}\right)^{*}$ & Percent of total (\%) \\
\hline Crown - provincial & 17194 & 36.7 \\
\hline Crown - federal ${ }^{* *}$ & 2703 & 5.7 \\
\hline Freehold & 23774 & 50.7 \\
\hline Mixed & 1042 & 2.2 \\
\hline Other & 1689 & 3.6 \\
\hline Water*** & 501 & 1.1 \\
\hline Total & 46903 & 100 \\
\hline
\end{tabular}

NOTE: The size of the subregion reported in Report 3 (Alberta Environmental Protection 1994b) is 46975.9 $\mathrm{km}^{2}$. The discrepancy of $72.85 \mathrm{~km}^{2}$ is due differing levels of precision between the land ownership and natural region GIS coverages.

* Land ownership figures were generated from LSAS quarter-section data, adjusted using 1:250,000 lake coverage.

** Federal crown lands include the Siksika Indian Reserve $\left(24 \mathrm{~km}^{2}\right)$ and CFB Suffield $\left(2679 \mathrm{~km}^{2}\right)$.

*** a GIS calculation of all waterbodies with an area of $1.5 \mathrm{~km}^{2}$ or larger.

\section{General Comments}

- Much of the subregion is fragmented, and includes:

- city of Medicine Hat.

- many towns and villages (e.g., Taber, Brooks, Bassano, Hanna, Youngstown, Oyen).

- farming, ranching and irrigation are major land uses. 
- Traversed by several highways (e.g., Highway $1,3,9,36,41$ and 61 ).

- Has the lowest road density of the four grassland subregions, at $0.41 \mathrm{~km} / \mathrm{km}^{2}$ (Table 5).

- Has the highest wellsite density of the four grassland subregions, at 1.11 wellsites $/ \mathrm{km}^{2}$ (Table 9).

- About $33 \%\left(15526 \mathrm{~km}^{2}\right)$ of the subregion has more than $76 \%$ native prairie remaining (Table 27). The majority of native prairie in this category is found as follows: southwest, north and east of CFB Suffield; in the Gem area; in the Lake Newell-Rolling Hills area; and, south of Dinosaur Provincial Park.

- About $14 \%\left(6483 \mathrm{~km}^{2}\right)$ of the subregion has between 51 to $75 \%$ native prairie remaining (Table 27). Much of the native prairie in this category occurs in the northern half of the subregion (Map $\mathrm{D}$, back pocket).

- At least $47 \%\left(22195 \mathrm{~km}^{2}\right)$ of the subregion has less than half native prairie remaining, and of that, at least $25 \%\left(11948 \mathrm{~km}^{2}\right)$ has no prairie remaining (Table 27). A significant portion of the southwestern and northeastern part of the subregion has no native prairie remaining.

Table 27. Amount of land $\left(\mathrm{km}^{2}\right)$ per category of remaining native prairie within the Dry Mixedgrass Subregion.

\begin{tabular}{|c|c|c|c|c|c|}
\hline \multirow{2}{*}{ Category } & \multicolumn{2}{|c|}{ Land area $\left(\mathrm{km}^{2}\right)$} & \multirow{2}{*}{ QSec + Twp. } & \multirow{2}{*}{$\begin{array}{c}\text { Sub-total } \\
(\%)\end{array}$} & \multirow{2}{*}{$\begin{array}{c}\text { Total } \\
(\%)\end{array}$} \\
\hline & QSec* & Twp.** & & & \\
\hline $76-100 \%$ & 11914 & 3612 & 15526 & 33 & \multirow{2}{*}{47} \\
\hline $51-75 \%$ & 981 & 5502 & 6483 & 14 & \\
\hline $26-50 \%$ & 1313 & 4848 & 6161 & 13 & \multirow{3}{*}{22} \\
\hline $1-25 \%$ & 2394 & -- & 2394 & 5 & \\
\hline $0-25 \%$ & --- & 1692 & 1692 & 4 & \\
\hline $0 \%$ & 11948 & -- & 11948 & 25 & 25 \\
\hline data unavailable & & & 2772 & 6 & 6 \\
\hline Total & 28550 & 15654 & 46976 & 100 & 100 \\
\hline \multicolumn{6}{|c|}{$\begin{array}{l}\text { * QSec - quarter section level native prairie GIS coverage } \\
\text { ** Twp. - township level native prairie GIS coverage } \\
\text { NOTE: Due to the precision levels of the data, especially township data, figures are estimates only. Federal } \\
\text { crown land is not included in these calculations. }\end{array}$} \\
\hline
\end{tabular}

\section{Protected Areas and ESAs}

- Contains six protected areas larger than $10 \mathrm{~km}^{2}$ (Table 19). They range in size from $10.7 \mathrm{~km}^{2}$ (Kennedy Coulee Ecological Reserve) to $420 \mathrm{~km}^{2}$ (Middle Sand Hills National Wildlife Area). The Middle Sand Hills NWA is a federally protected area. 
- A total of 67 ESAs occur wholly or partially within the subregion (Map C, back pocket). These include:

- 6 internationally significant ESAs: Chappice-Sam Lakes, Dinosaur, Kirkpatrick Native Prairie, Milk River Section, Verdigris Coulee, Writing-On-Stone

- 18 nationally significant ESAs: Forty Mile Coulee, Grassy Island Native Prairie, Lake Newell, Lower Bow Dunes, Many Island Lake, Manyberries Creek Badlands, Milk River Canyon, Native Prairie (Brostem Reservoir), Pakowki Lake, Red Deer River-Bindloss/Empress Terraces, Remount, Ross Creek, Sage Creek, South Saskatchewan Canyon, South Saskatchewan River-Medicine Hat North, Suffield, Travers Reservoir, Turin Dunes

- 43 provincially significant ESAs: Alkali Creek Moraine, Bow River-Bow City/Scandia, Bow River-Hays, Bow River-Majorville, Coleman Lake, Deer Creek, Dune Point Springs, Eagle Butte, Empress Creek, Esther/Douglas Lake Native Prairie, Etzikom Coulee, Fincastle Lake, Grassy Lake Wetlands, Hays Reservoir, Jenner Moraine, Jenner Springs, Kininvie, Lafine White-Tailed Deer Habitat, Lathom-San Francisco Lakes, Little Bow Reservoir, Little Rolling Hills, Louisiana Lakes, Majorville, Majorville Wetlands, McAlpine Creek, Middle Sand Hills, Milk River-Breed Creek, Milk River-Pakowki/Pinhorn, Muddy Buttes, Murray Lake, Native Prairie (Major Lake), Oldman River-Lethbridge East, Purple Springs Dunes, Red Deer River-Alkali Creek/Dune Point, Red Deer River-Finnegan/Steveville Terraces, Red Deer River-Jenner, Red Rock Coulee, Sounding Creek Native Prairie, South Saskatchewan River-Medicine Hat West, Taber Lake, Tyrell-Rush Lakes, Wolf Island Dunes, Youngstown Aspen Groveland.

\section{Targets and Prospects for Protection}

The target for protection of Level 1 Natural History Themes is adequate representation of 13 Natural History Themes, which total a minimum of $1252.5 \mathrm{~km}^{2}$, or about $2.7 \%$ of the subregion (Table 20). To date, six protected areas greater than $10 \mathrm{~km}^{2}$ have been established within the subregion and about $13 \%$ of the overall target of $1252.5 \mathrm{~km}^{2}$ has been achieved. There are several high quality areas within the subregion that would help to meet some or all of the remaining Level 1 NHT targets. Areas with the greatest potential are those remaining blocks of intact prairie greater than $10 \mathrm{~km}^{2}$ in size, several of which have been identified as ESAs. The following discussion addresses each of these areas in detail. Their location is shown on Map 7. 


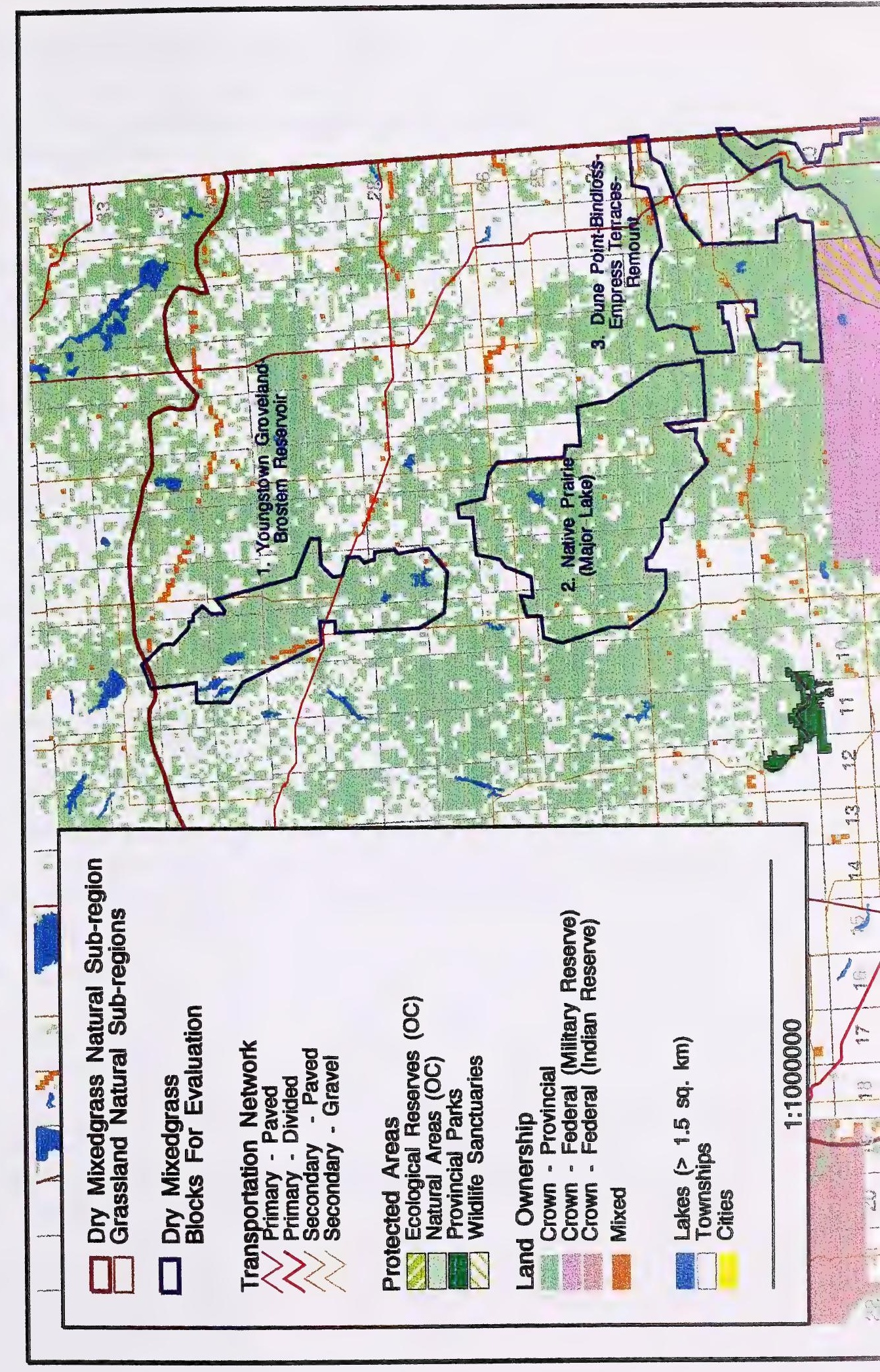




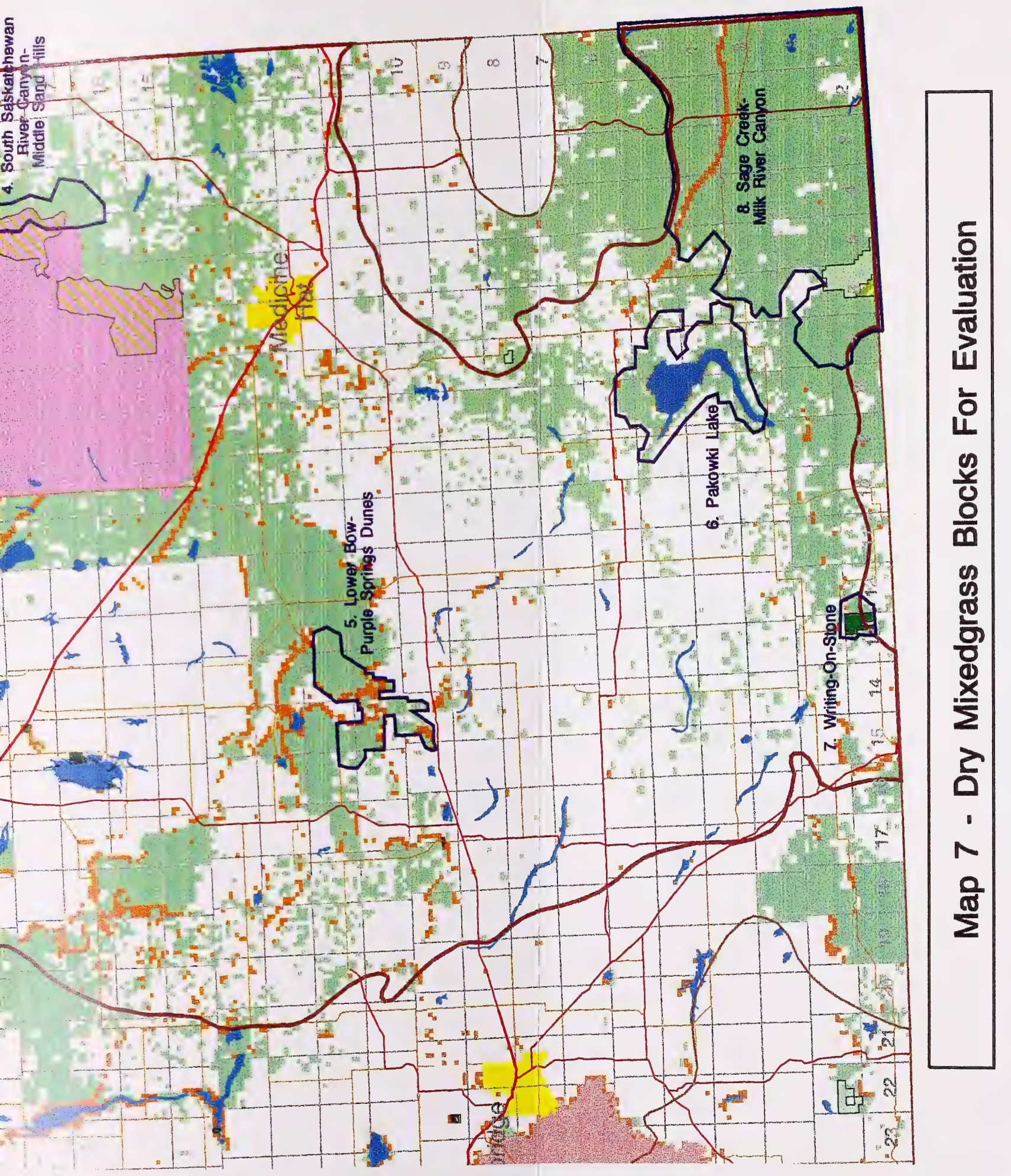




\subsection{Youngstown Groveland-Brostem Reservoir Block}

- Most of the area has $50 \%$ or more native prairie.

- A sizeable area of contiguous crown land greater than $10 \mathrm{~km}^{2}$ occurs within this block.

- Includes the following ESAs:

(a) Youngstown Aspen Groveland (provincially significant)

- ESA is about $98 \%$ within the subregion.

- Biophysical features include:

- significant aspen and dune complex

- hummocky moraine

- high diversity of bird species

- ephemeral wetlands

- dancing grounds of sharp-tailed grouse (YELLOw A-listed by AEP 1996)

(b) Native Prairie-Brostem Reservoir (nationally significant)

- ESA is entirely within the subregion.

- Biophysical features include:

- extensive mixed grasslands

- $\quad$ several wetland types (e.g., wet meadow, alkali ponds)

- potential shorebird staging and nesting habitat

- Loggerhead Shrike (YELLOW A-listed by AEP 1996; threatened rating by COSEWIC)

- This block also contains Antelope Lake and Plover Lake - significant waterfowl staging and production lakes. Antelope Lake has other important features, including: deep and shallow marshes, a Ring-billed Gull colony, ephemeral wetlands, and habitats for Prairie Falcon (YELLOW A-listed by AEP 1996), Golden Eagle (YELLOw B-listed by AEP 1996), Ferruginous Hawk (BLUE-listed by AEP 1996; vulnerable rating by COSEWIC), Burrowing Owl (RED-listed by AEP 1996; endangered rating by COSEWIC) and Sharp-tailed Grouse (YELLow A-listed by AEP 1996). Plover Lake, with its exposed mud flats, is a significant shorebird area. It also has a Ring-billed Gull colony.

\section{Potential for contributing to Level 1 Natural History Theme representation:}

Crown lands within this block have excellent potential for contributing to the following NHTs, most of which are under-represented.

- Youngstown Aspen Groveland ESA: ground moraine, sandy plain, dune field, wet meadow, alkali wetland.

- Native Prairie-Brostem Reservoir ESA: ground moraine, sandy plain, wet meadow, shallow marsh, alkali wetland. 


\subsection{Native Prairie (Major Lake) Block}

- Most of the area has $50 \%$ or more remaining in native prairie.

- Sizeable areas of contiguous crown land greater than $10 \mathrm{~km}^{2}$ occur within this block.

- Includes the following ESA:

Native Prairie(Major Lake) (provincially significant)

- ESA is entirely within the subregion.

- Biophysical features include:

- extensive mixedgrass community

- wet meadows, ephemeral ponds, alkali wetlands

- habitat for Baird's Sparrow (Yellow A-listed by AEP 1996), Upland Sandpiper (yellow A-listed by AEP 1996), Long-billed Curlew (BLUE-listed by AEP 1996)

- potential habitat for Burrowing Owl (RED-listed by AEP 1996; endangered rating by COSEWIC)

\section{Potential for contributing to Level 1 Natural History Theme representation:}

Crown lands within this block have good potential for contributing to the following NHTs, most of which are under-represented:

- Native Prairie (Major Lake) ESA: ground moraine, hummocky moraine, sandy plain, exposed slope, protected slope, wet meadow, shallow marsh, alkali wetland.

\subsection{Dune Point-Bindloss-Empress Terraces-Remount Block}

- Most of the area is $50 \%$ or more native prairie.

- Sizeable areas of contiguous crown land greater than $10 \mathrm{~km}^{2}$ occur within this block.

- Includes the following ESAs:

(a) Red Deer River-Bindloss/Empress Terraces (nationally significant)

- ESA is entirely within the subregion.

- Most extensive and diverse plains cottonwood ecosystem in Canada.

- Biophysical features include:

- extensive river valley habitats, open water, cutbanks, riparian shrubbery

- cottonwood stands, channel wetlands

- grasslands, sand dunes, sagebrush and alkali flats

- massive river terraces

- diverse breeding bird populations

- one of most important sites in Canada for Loggerhead Shrike (YELlow A-listed by AEP 1996; threatened rating by COSEWIC)

- key habitat for Mule Deer, White-tailed Deer and Pronghorn (YeLLow B-listed by AEP 1996)

- Sharp-tailed Grouse (YELLOw A-listed by AEP 1996) habitat, dancing grounds 
- active sand dunes

- priority plant species, including: annual skeletonweed (Lygodesmia rostrata, S2), annual lupine (Lupinus pusillus, S3), bur ragweed (Franseria acanthicarpa, S2), low yellow evening-primrose (Oenothera flava, S2?), shrubby evening-primrose (Oenothera serrulata, S2).

- Western Hognose Snake (BLUE-listed by AEP 1996)

- alkali wetlands and springs

- locally important for staging and breeding geese

\section{(b) Dune Point Springs (provincially significant)}

- ESA is entirely within the subregion.

- Biophysical features include:

- eroding slopes and coulees of the Red Deer River

- nesting area for sensitive bird species, including: Golden Eagle (YELLOW B-listed by AEP 1996) and Loggerhead Shrike (YELLOw A-listed by AEP 1996; threatened rating by COSEWIC)

- extensive, diverse springs with numerous priority plant species, including: few-flowered aster (Aster pauciflorus, S2), common beggarticks (Bidens frondosa, S2), Virginia wild rye (Elymus virginicus, S2), and Manitoba maple (Acer negundo, S2?)

- diverse coulee woodlands, shrubbery and grasslands

- key habitat for Mule Deer and Pronghorn (YeLLOw B-listed by AEP 1996)

\section{(c) Red Deer River-Alkali Creek/Dune Point (provincially significant)}

- ESA is entirely within the subregion.

- One of most diverse river valley systems in Alberta.

- Biophysical features include:

- diverse coulee woodlands, shrubbery, grasslands, riparian habitats

- rock outcrops, eroding slopes

- active sand dunes

- extensive diverse alkali springs (some of the best in Alberta)

- priority plant species, including: few-flowered aster (Aster pauciflorus, S2), common beggarticks (Bidens frondosa, S2); Virginia wild rye (Elymus virginicus, S2), Manitoba maple (Acer negundo, S2?), American water-horehound (Lycopus americanus, S2), little-seed rice grass (Oryzopsis micrantha, S2), annual skeletonweed (Lygodesmia rostrata, S2), bur ragweed (Franseria acanthicarpa, S2) low milk vetch (Astragalus lotiflorus, S2), annual lupine (Lupinus pusillus, $\mathrm{S} 3$ ), shrubby evening-primrose (Oenothera serrulata, S2), prickly milk vetch Astragalus kentrophyta, S1S2)

- variety of breeding birds

- extensive gravelly blowouts, one of the few examples in Alberta

- nesting area for Prairie Falcon (YeLLow A-listed by AEP 1996), Golden Eagle (YELLOW B-listed by AEP 1996) and Loggerhead Shrike (YELLOW A-listed by AEP 1996; threatened rating by COSEWIC)

- Sharp-tailed Grouse (YELLOW A-listed by AEP 1996) habitat and dancing grounds 
- habitat for Plains Garter Snake (YELLOW A-listed by AEP 1996), Wandering Garter Snake (YELLOW A-listed by AEP 1996), Prairie Rattlesnake (BLUE-listed by AEP 1996), Bull Snake (YeLLow в-listed by AEP 1996), Western Hognose Snake (BLUElisted by AEP 1996) and Northern Leopard Frog (RED-listed by AEP 1996)

- most northerly and extensive population in Alberta of Ord's Kangaroo Rat (BLUElisted by AEP 1996)

- locally important for breeding geese

(d) Remount (nationally significant)

- ESA is entirely within the subregion.

- One of largest continuous blocks of native grassland in Alberta.

- Most consistent area for observing Western Hognose Snake (BLUE-listed by AEP 1996) in Alberta.

- Biophysical features include:

- extensive mixedgrass

- ephemeral wetlands

- key habitat for Pronghorn (YELLOw B-listed by AEP 1996)

- habitat for sensitive and at risk species, including: Prairie Falcon (Yellow A-listed by AEP 1996), Golden Eagle (YeLLow в-listed by AEP 1996), Loggerhead Shrike (YELLOw A-listed by AEP 1996; threatened rating by COSEWIC), Ferruginous Hawk (BLUE-listed by AEP 1996; vulnerable rating by COSEWIC), Burrowing Owl (RED-listed by AEP 1996; endangered rating by COSEWIC) and Western Hognose Snake (BLUE-listed by AEP 1996)

\section{Potential for contributing to Level 1 Natural History Theme representation:}

Crown lands within this block have excellent potential for contributing to the following NHTs, most of which are under-represented.

- Red Deer River-Bindloss/Empress Terraces ESA: exposed slope, protected slope, floor/stream, springs, alkali wetland.

- Dune Point Springs ESA: exposed slope, protected slope, springs.

- Red Deer River-Alkali Creek/Dune Point ESA: dune field, exposed slope, protected slope, floor/stream, springs.

- Remount ESA: hummocky moraine, sandy plain, dune field, springs, wet meadow, alkali wetland.

\subsection{South Saskatchewan River Canyon-Middle Sand Hills Block}

- Most of the area is $75 \%$ or more native prairie.

- Sizeable areas of contiguous crown land greater than $10 \mathrm{~km}^{2}$ occur within this block.

- Contains the Prairie Coulees Natural Area $\left(17.8 \mathrm{~km}^{2}\right)$. 
- Includes the following ESAs:

(a) South Saskatchewan Canyon (nationally significant)

- ESA is entirely within the subregion.

- Biophysical features include:

- spectacular canyon of the South Saskatchewan River

- eroding cutbanks, slump blocks and rugged badlands

- diverse coulee shrubbery and locally extensive riparian habitat

- extensive springs, including lightly or ungrazed areas

- nesting area for birds of prey, including: Prairie Falcon (YeLlow A-listed by AEP 1996), Ferruginous Hawk (BLUE-listed by AEP 1996; vulnerable rating by COSEWIC) and Golden Eagle (YELLow B-listed by AEP 1996)

- feeding area for American White Pelicans (YELLOW B-listed by AEP 1996)

- locally important breeding area and provincially important staging area for Canada Geese

- snake hibernacula

- habitat for Short-horned Lizard (BLUE-listed by AEP 1996; vulnerable rating by COSEWIC)

- priority plant species, including: few-flowered aster (Aster pauciflorus, S2), littleseed rice-grass (Oryzopsis micrantha, S2), American pellitory (Parietaria pensylvanica, S3), bushy cinquefoil (Potentilla paradoxa, S2), clammyweed (Polanisia dodecandra, S1), Carolina whitlow-grass (Draba reptans, S2), smooth sweet-cicely (Osmorhiza longistylis, S2), common beggar-ticks (Bidens frondosa, S2), prairie wedge grass (Sphenopholis obtusata, S2), rush-pink (Stephanomeria runcinata, S2), nodding umbrella-plant (Eriogonum cernuum, S2), and smallflowered hawksbeard (Crepis occidentalis, S2)

- deep river pools important to Lake Sturgeon (S3).

(b) Middle Sand Hills (provincially significant)

- ESA is entirely within the subregion.

- Biophysical features include:

- diverse sand plain

- ephemeral wetlands

- dune vegetation ranging from aspen woodland and a variety of tall and low shrubbery and grassland to active blowouts

- sensitive and at risk species, including: Ord's Kangaroo Rat (BLuE-listed by AEP 1996), Baird's Sparrow (YELlow A-listed by AEP 1996), Loggerhead Shrike (YELLOW A-listed by AEP 1996; threatened rating by COSEWIC), Ferruginous Hawk (BLUE-listed by AEP 1996; vulnerable rating by COSEWIC), Great Plains Toad (RED-listed by AEP 1996) and Western Hognose Snake (BLUE-listed by AEP 1996)

- Sharp-tailed Grouse (Yellow A-listed by AEP 1996) dancing grounds

- priority plant species, including: bur ragweed (Franseria acanthicarpa, S2), Pursh's milk vetch (Astragalus purshii, S2), annual skeletonweed (Lygodesmia rostrata, S2) and smooth narrow-leaved goosefoot (Chenopodium subglabrum, S2). 


\section{Potential for contributing to Level 1 Natural History Theme representation:}

Crown lands within this block have excellent potential for contributing to the following NHTs, most of which are under-represented:

- South Saskatchewan Canyon ESA: exposed slope, protected slope, floor/stream, springs.

- Middle Sand Hills ESA: hummocky moraine, sandy plain, dune field, wet meadow.

\subsection{Lower Bow-Purple Springs Dunes Block}

- Most of the area is $50 \%$ or more native prairie.

- Sizeable areas of contiguous crown land greater than $10 \mathrm{~km}^{2}$ occur within this block.

- Includes the following ESAs:

(a) Lower Bow Dunes (nationally significant)

- ESA is entirely within the subregion.

- Extensive oil and gas development, particularly in the southern half.

- Biophysical features include:

- native mixed grassland and sagebrush on sand dune terrain with active blowouts

- priority plant species, including: low milk vetch (Astragalus lotiflorus, S2), prickly milk vetch (Astragalus kentrophyta, S1S2), annual lupine (Lupinus pusillus, S3), and sand verbena (Abronia micrantha, $\mathrm{S} 1$ )

- key habitat for Pronghorn (YeLLow B-listed by AEP 1996)

- habitat for Grasshopper Sparrow (YELLOw B-listed by AEP 1996)

- feeding area for birds of prey that nest along the Oldman and Bow Rivers

- major spring

- breeding wetlands for Great Plains Toad (RED-listed by AEP 1996)

- waterfowl production and staging on wetlands in southern portion of the unit

(b) Purple Springs Dunes (provincially significant)

- ESA is entirely within the subregion.

- Wolf Island, a site near this ESA, is under land use reservation (Protective Notation) as a proposed Natural Area.

- Several wetlands and marshes associated with irrigation developments.

- Biophysical features include:

- native mixed grassland and sagebrush on stabilized sand dune terrain with some active blowouts

- priority plant species, including: annual lupine (Lupinus pusillus, S3), sand verbena (Abronia micrantha, S1), bur ragweed (Franseria acanthicarpa, S2) and smooth narrow-leaved goosefoot (Chenopodium subglabrum, S2).

- breeding habitat for Upland Sandpiper (YELLOw A-listed by AEP 1996), Grasshopper Sparrow (YELLow B-listed by AEP 1996) and Brewer's Sparrow (YELLOW в-listed by AEP 1996)

- several Sharp-tailed Grouse (YELLOw A-listed by AEP 1996) dancing grounds 
- feeding area for rare birds of prey that nest along the Oldman River

- major breeding populations of Great Plains Toad (RED-listed by AEP 1996) through the western half of this area

- Plains Spadefoot Toad (BLUE-listed by AEP 1996) in several ponds in southwestern portion

- Black-crowned Night Heron (YELLOw B-listed by AEP 1996), Great Blue Heron (YeLlow в-listed by AEP 1996) and American White Pelican (Yellow B-listed by AEP 1996) feeding area on large wetland at north end

- waterfowl production for diving and puddle ducks

- some shorebird nesting and migration

(c) Wolf Island Dunes (provincially significant)

- ESA is entirely within the subregion.

- Biophysical features include:

- native mixed grassland on sand dune terrain with active blowouts

- priority plant species, including: annual lupine (Lupinus pusillus, S3), sand verbena (Abronia micrantha, S1), and bur ragweed (Franseria acanthicarpa, S2),

- breeding habitat for Grasshopper Sparrow (YELLOw B-listed by AEP 1996) and Brewer's Sparrow (YELLOw B-listed by AEP 1996)

- nesting Burrowing Owls (RED-listed by AEP 1996; endangered rating by COSEWIC)

\section{Potential for contributing to Level 1 Natural History Theme representation:}

Crown lands within this block have excellent potential for contributing to the following NHTs, most of which are under-represented.

- Lower Bow Dunes ESA: ground moraine, sandy plain, dune field, wet meadow, shallow marsh, deep marsh.

- Purple Springs Dunes ESA: hummocky moraine, sandy plain, dune field, wet meadow, shallow marsh, deep marsh.

- Wolf Island Dunes ESA: ground moraine, sandy plain, dune field, wet meadow.

\subsection{Pakowki Lake Block}

- Most of the area is $75 \%$ or more native prairie.

- Sizeable areas of contiguous crown land greater than $10 \mathrm{~km}^{2}$ occur within this block.

- Includes the following ESA:

\section{Pakowki Lake (nationally significant)}

- ESA is entirely within the subregion.

- Biophysical features include:

- impressive glacial spillway channel

- large playa lake and sand dune-wetland complex

- extensive bulrush marshes and open water 
- waterfowl staging and production area

- occurrence of Snowy Egrets, a species normally breeding in the southern U.S.

- nesting colonies of American White Pelican (YELLow B-listed by AEP 1996) and Double-crested Cormorant (YeLLow B-listed by AEP 1996)

- 'nesting area for Black-necked Stilts (YELLOw B-listed by AEP 1996), Ferruginous Hawks (BLUE-listed by AEP 1996; vulnerable rating by COSEWIC) and Loggerhead Shrikes (YELLOW A-listed by AEP 1996; threatened rating by COSEWIC)

- habitat for sensitive and at risk species, including: Western Hognose Snake (BLUElisted by AEP 1996), Western Grebe (YELLOw B-listed by AEP 1996), Black-crowned Night Heron (Yellow B-listed by AEP 1996), Caspian Tern (YELLow B-listed by AEP 1996) and Forster's Tern (YELLOw B-listed by AEP 1996)

- migratory stopover for Whimbrel and Eurasian Wigeon

- shorebird staging area

- diversity of marsh birds and colonial nesting birds such as gulls and terns

- priority plant species, on sand dunes and in wetlands, including: bur ragweed (Franseria acanthicarpa, S2), sand nut-grass (Cyperus schweinitzii, S2), annual skeletonweed (Lygodesmia rostrata, S2), downingia (Downingia laeta, S1), western spiderwort (Tradescantia occidentalis, S1) and smooth narrow-leaved goosefoot (Chenopodium subglabrum, S2).

- dancing grounds of Sharp-tailed Grouse (YELLOw A-listed by AEP 1996) and Sage Grouse (BLUE-listed by AEP 1996)

- key habitat for Pronghorn (YELLOw B-listed by AEP 1996) along the east shore

\section{Potential for contributing to Level 1 Natural History Theme representation:}

Crown lands within this block have excellent potential for contributing to the following NHTs, most of which are under-represented.

- Pakowki Lake ESA: ground moraine, hummocky moraine, sandy plain, dune field, floor/stream, springs, wet meadow, shallow marsh, deep marsh, alkali wetland.

\subsection{Writing-On-Stone Block}

- Most of the area is $75 \%$ native prairie.

- Writing-On-Stone Provincial Park occurs within the block.

- Ungrazed mixed grasslands, coulee and riparian habitats in Writing-On-Stone Provincial Park.

- Areas of contiguous crown land greater than $10 \mathrm{~km}^{2}$.

- Includes the following ESA:

\section{Writing-On-Stone (internationally significant)}

- ESA is about $70 \%$ within the subregion.

- Biophysical features include:

- diverse and productive riparian plains cottonwood, low and tall shrubbery 
- beaver ponds, moist alkaline meadows, clear streams

- rock outcrops and grasslands

- massive sandstone outcrops and intriguing rock formations

- high density of nesting birds of prey including Prairie Falcon (YELLOw A-listed by AEP 1996), Golden Eagle (YELLOw B-listed by AEP 1996) and Ferruginous Hawk (BLUE-listed by AEP 1996; vulnerable rating by COSEWIC)

- historic nesting area for Peregrine Falcons (RED-listed by AEP 1996; endangered rating by COSEWIC)

- habitat for Bobcats (YELLOw B-listed by AEP 1996) and Yellow-bellied Marmots

- diverse populations and high numbers of breeding and migrating birds

- rare or uncommon butterflies

- hibernacula for Prairie Rattlesnake (BLUE-listed by AEP 1996) and Bull Snake (YELLOW в-listed by AEP 1996)

- populations of Short-horned Lizard (BLUE-listed by AEP 1996; vulnerable rating by COSEWIC) along coulee rims

- priority plant species, including: nodding umbrella plant (Eriogonum cernuum, S2), green milkweed (Asclepias viridiflora, S1), Moquin's sea-blite (Suaeda moquinii, S2), prickly milk-vetch (Astragalus kentrophyta, S1S2), low milk-vetch (Astragalus lotiflorus, S2), small-flowered hawksbeard (Crepis occidentalis, S2), tufted hymenopappus (Hymenopappus filifolius, S1S2), red three-awn (Aristida longiseta, $\mathrm{S} 1$ ), downy paintbrush (Castilleja sessiliflora, $\mathrm{S} 1$ ), little-seed rice-grass (Oryzopsis micrantha, S2), American pellitory (Parietaria pensylvanica, S3)

- sandy outwash plain on upland north of the river

- type section for Upper Cretaceous rocks of the Lower Milk River Formation in Police Coulee in Section 35-T1-R13-W4

- rare fish, including: Brassy Minnow (S1), Western Silvery Minnow (S1) and Stonecat (S1)

\section{Potential for contributing to Level 1 Natural History Theme representation:}

Crown lands within this block have excellent potential for contributing to the following NHTs, most of which are under-represented:

- Writing-On-Stone ESA: glacial lake bed, hummocky moraine, exposed slope, protected slope, floor/stream, springs.

\subsection{Sage Creek-Milk River Canyon Block}

- Most of the area is $75 \%$ or more native prairie.

- Large areas of contiguous crown land greater than $10 \mathrm{~km}^{2}$.

- Includes the following ESAs:

(a) Sage Creek (nationally significant)

- ESA is about $98 \%$ within the subregion. 
- Contains two sites under land use reservation as proposed Natural Areas - Milk River Lake (Protective Notation) and Buffalo Trail (Protective Notation).

- Biophysical features include:

- extensive mixed grassland and ephemeral saline wetlands

- minor badlands and tall shrub riparian habitats along streams

- priority plant species, including: Pursh's milk vetch (Astragalus purshii, S2), bushy cinquefoil (Potentilla paradoxa, S2), saltbush (Atriplex truncata, S1), bahia (Bahia oppositifolia, S1), flowering-quillwort (Lilaea scilloides, S1), rush-pink (Stephanomeria runcinata, S2), nodding umbrella-plant (Eriogonum cernuum, S2), small-flowered hawksbeard (Crepis occidentalis, S2), woollyheads (Psilocarphus elatior, S2) and smooth boisduvalia (Boisduvalia glabella, S2)

- habitat for sensitive or at risk species, including: Bobolink (YELLOW B-listed by AEP 1996), Mountain Plover (YeLlow B-listed by AEP 1996), Baird's Sparrow (Yellow A-listed by AEP 1996), Ferruginous Hawk (BLuE-listed by AEP 1996; vulnerable rating by COSEWIC), Burrowing Owl (RED-listed by AEP 1996; endangered rating by COSEWIC), Loggerhead Shrike (YELLOw A-listed by AEP 1996; threatened rating by COSEWIC)

- dancing grounds of Sage Grouse (BLUE-listed by AEP 1996) and Sharp-tailed Grouse (YELLOW A-listed by AEP 1996)

- key habitat for Pronghorn (Yellow B-listed by AEP 1996) and Mule Deer

- habitat for Swift Fox (RED-listed by AEP 1996); includes several release sites

- productive wetlands in wetter years; includes Milk River (Wild Horse) Lake

- large esker ridge

\section{(b) Milk River Canyon (nationally significant)}

- ESA is about $98 \%$ within the subregion.

- Contains two sites under land use reservation as proposed Natural Areas - Pinhorn (Protective Notation) and Lost River (Consultative Notation).

- A remote wilderness setting surrounding the spectacular canyon of the Milk River.

- Biophysical features include:

- extensive rugged badlands and massive sandstone outcrops

- intriguing rock formations

- diverse riparian woodlands, shrubbery, and wetlands

- minor sand dune area

- extensive lightly to ungrazed grasslands and wooded springs

- priority plant species, including: one-spike oatgrass (Danthonia unispicata, S2), scratch grass (Muhlenbergia asperifolia, S2), American pellitory (Parietaria pensylvanica, S3), Watson's knotweed (Polygonum watsonii, S2), Pursh's milk-vetch (Astragalus purshii, S2), smooth boisduvalia (Boisduvalia glabella, S2), upland evening-primrose (Oenothera andina, S1), Moquin's sea-blite (Suaeda moquinii, S2), prickly milk-vetch (Astragalus kentrophyta, S1S2), smallflowered hawksbeard (Crepis occidentalis, S2), nodding umbrella-plant (Eriogonum cernuum, S2), dwarf fleabane (Erigeron radicatus, S2), prairie false dandelion (Nothocalais cuspidata, S2), soapweed (Yucca glauca, S1), Nebraska sedge (Carex nebraskensis, S2), and woolly-heads (Psilocarphus elatior, S2) 
- habitat for sensitive and at risk species, including: Western Hognose Snake (BLUE-listed by AEP 1996), Short-horned Lizard (BLuE-listed by AEP 1996; vulnerable rating by COSEWIC), Golden Eagle (YELLow B-listed by AEP 1996), Loggerhead Shrike (YELLOW A-listed by AEP 1996; threatened rating by COSEWIC), Baird's Sparrow (YELlow A-listed by AEP 1996) and Swift Fox (RED-listed by EP, 1996b)

- hibernacula for Prairie Rattlesnake (BLuE-listed by AEP 1996) and Bull Snake (YELLOW B-listed by AEP 1996)

- populations of Weidemeyer's Admiral Butterfly

- rare fish, including: Brassy Minnow (S1), Western Silvery Minnow (S1) and Stonecat (S1)

- diversity of breeding birds, including: Violet-green Swallow, Lazuli Bunting, Black-headed Grosbeak and the Bullock's form of the Northern Oriole

- nesting habitat for birds of prey including Prairie Falcon (YELLOw A-listed by AEP 1996), Golden Eagle (YELLow B-listed by AEP 1996) and Ferruginous Hawk (BLUE-listed by AEP 1996; vulnerable rating by COSEWIC)

- Sharp-tailed Grouse (YELLOW A-listed by AEP 1996) dancing grounds

\section{(c) Manyberries Creek Badlands (nationally significant)}

- ESA is about $10 \%$ within the subregion.

- Biophysical features include:

- extensive area of grassland

- badlands with intriguing juniper patterning on sandier soils

- riparian creek habitats at the base of the Manyberries badlands

- extensive riparian tall shrubbery along southeastern drainages

- saline springs with diverse butterfly populations

- priority plant species, including: one-spike oat-grass (Danthonia unispicata, S2), Watson's knotweed (Polygonum watsonii, S2) and rush pink (Stephanomeria runcinata, S2)

- habitat for Short-horned Lizard (BLUE-listed by AEP 1996; vulnerable rating by COSEWIC)

- dancing grounds of Sage Grouse (BLUE-listed by AEP 1996) and Sharp-tailed Grouse (YelLow A-listed by AEP 1996)

- nesting area for Ferruginous Hawks (BLUE-listed by AEP 1996; vulnerable rating by COSEWIC) and Burrowing Owls (RED-listed by AEP 1996; endangered rating by COSEWIC)

\section{Potential for contributing to Level 1 Natural History Theme representation:}

Crown lands within this block have excellent potential for contributing to the following NHTs, most of which are under-represented.

- Sage Creek ESA: ground moraine, hummocky moraine, sandy plain, exposed slope, floor/stream, springs, wet meadow, alkali wetland. 
- Milk River Canyon ESA: ground moraine, hummocky moraine, exposed slope, protected slope, floor/stream, springs, wet meadow, alkali wetland.

- Manyberries Creek Badlands ESA: ground moraine, hummocky moraine, exposed slope, floor/stream, springs, wet meadow.

\section{Other Areas of Significance}

These are areas that are generally not large enough to contribute to the representation of Level 1 NHTs, yet have been recognized for their biophysical importance.

\section{A. Dinosaur ESA}

- An internationally significant ESA.

- Dinosaur Provincial Park occupies much of the ESA.

- Biophysical features include:

- extensive badlands and intriguing rock formations

- extensive cottonwood, tall shrub, and low shrub riparian habitats

- diverse breeding bird habitat

- active Great Blue Heron (YeLLow B-listed by AEP 1996) colony

- snake hibernacula

- nesting area for sensitive and at risk species, including: Loggerhead Shrike (YELLOW Alisted by AEP 1996; threatened rating by COSEWIC), Ferruginous Hawk (BLUE-listed by AEP, 1996b; vulnerable rating by COSEWIC), Golden Eagle (YELLOw в-listed by AEP 1996) and Prairie Falcon (Yellow A-listed by AEP 1996)

- priority plant species, including: low annual lupine (Lupinus pusillus S3), nodding umbrella-plant (Eriogonum cernuum, S2) and rush-pink (Stephanomeria runcinata, S2)

- locally important for breeding geese

- habitat for Saw-whet Owl

\section{Considerations}

- Maintain all remaining crown land within this ESA in a natural state.

- Including crown lands adjacent to Dinosaur Provincial Park would add to the ecological integrity of the park and the area's long-term viability.

\section{B. Chappice-Sam Lakes ESA}

- An internationally significant ESA.

- Most of the area is $75 \%$ or more native prairie.

- Sizeable areas of contiguous crown land greater than $10 \mathrm{~km}^{2}$ occur within this ESA.

- Impacted by PNG and other developments which decreases the area's potential to contribute to representation of Level 1 NHTs. 
- Biophysical features include:

- permanent hypersaline lakes

- extensive saline spring/seepage in excellent condition

- waterfowl production and staging area

- shorebird staging area

- abundant ground squirrel population (important bird of prey feeding area)

- nesting habitat for Piping Plover (RED-listed by AEP 1996; endangered rating by COSEWIC)

- habitat for Baird's Sparrow (YeLLow A-listed by AEP 1996), Long-tailed Weasel (YELLOW A-listed by AEP 1996), Ferruginous Hawk (BLUE-listed by AEP 1996; vulnerable rating by COSEWIC) and Golden Eagle (YELLow B-listed by AEP 1996)

- priority plant species, including: Nevada bulrush (Juncus nevadensis, S1) and scratch grass (Muhlenbergia asperifolia, $\mathrm{S} 2$ )

- key Mule Deer habitat

\section{Considerations:}

- Maintain all remaining crown land within this ESA in a natural state.

- Even though impacted, all crown land parcels should be conserved in recognition of their international significance. Restoration of disturbed areas would likely be required.

\section{Verdigris Coulee ESA}

- An internationally significant ESA.

- Much of the area is $50 \%$ or more native prairie.

- No areas of contiguous crown land greater than $10 \mathrm{~km}^{2}$ occur within this ESA.

- Contains one site under land use reservation for establishment as a Natural Area - Verdigris Coulee (Protective Notation).

- Biophysical features include:

- classic glacial spillway

- diverse badland, moist meadow, grassland, shrub and open water habitats

- key Mule Deer habitat

- priority plant species, including: Moquin's sea-blite (Suaeda moquinii, S2)

- nesting birds of prey, including Ferruginous Hawk (BLUE-listed by AEP 1996; vulnerable rating by COSEWIC)

- major waterfowl staging and production areas in Weston and Verdigris Lake

- lakes used by the American White Pelican (YeLLow в-listed by AEP 1996)

- major fossil finds in Verdigris Coulee.

\section{Considerations:}

- Maintain all remaining crown land within this ESA in a natural state.

- All crown land parcels should be conserved in recognition of their international significance. 


\section{Meeting Level 1 Natural History Theme Targets}

Recommendations for meeting each of the Level 1 NHT targets are presented below. Although each is presented separately, potential protected areas may encompass more than one theme. To ensure maintenance of ecological integrity, representative protected areas ideally need to be greater than $10 \mathrm{~km}^{2}$ (where possible) and include representation of the themes across their range of variation. To ensure adequate representation of the region's biodiversity, several sites across the region need to be considered. Expanding current protected areas will ensure ecological integrity and is an effective way of meeting goals.

- Glacial lake bed: To meet the Level 1 NHT targets, about $197 \mathrm{~km}^{2}$ of this theme are required. Only three ESAs contain examples of this theme - Writing-On-Stone, Louisiana Lakes and Lafine White-tailed Deer Habitat (ANHIC 1997). The amount of glacial lake bed within these three ESAs is considerably less than $200 \mathrm{~km}^{2}$. The targets for this theme, therefore, cannot be met within those ESAs ranked as provincial and higher in significance. Given the small amounts of uncultivated glacial lake bed landscape remaining in this subregion, it is unlikely that the targets for this theme can be met.

Recommendation: Consider protecting all remaining sites containing this theme, particularly the Writing-On-Stone area.

- Ground moraine: To meet the Level 1 NHT targets, about $182 \mathrm{~km}^{2}$ of this theme are required. Several blocks could contribute to representation of this theme: Youngstown Groveland-Brostem Reservoir; Native Prairie (Major Lake); Pakowki Lake and Sage CreekMilk River Canyon (Table 28). The targets for this theme can probably be met from within these blocks.

Recommendation: Focus on the Youngstown Groveland-Brostem Reservoir Block and the Sage Creek-Milk River Canyon Block to ensure representation of this theme across its range of variation.

- Hummocky moraine: To meet the Level 1 NHT targets, about $177 \mathrm{~km}^{2}$ of this theme are required. Several blocks could contribute to representation of this theme: Native Prairie (Major Lake); Pakowki Lake and Sage Creek-Milk River Canyon (Table 28). The targets for this theme can probably be met from within these blocks.

Recommendation: Focus on the Native Prairie (Major Lake) Block and the Sage Creek-Milk River Canyon Block to ensure representation of this theme across its range of variation.

- Sandy plain: To meet the Level 1 NHT targets, about $188 \mathrm{~km}^{2}$ of this theme are required. Several blocks could contribute to representation of this theme: Youngstown GrovelandBrostem Reservoir; Dune Point-Bindloss-Empress Terraces-Remount; South Saskatchewan River Canyon-Middle Sand Hills; Lower Bow-Purple Springs Dunes and Pakowki Lake (Table 28). The targets for this theme can probably be met from within these blocks. 
Recommendation: Focus on the Dune Point-Bindloss-Empress Terraces-Remount Block, the Lower Bow-Purple Springs Dunes Block and the Pakowki Lake Block to ensure representation of this theme across its range of variation.

- Dune field: To meet the Level 1 NHT targets, about $200 \mathrm{~km}^{2}$ of this theme are required. Several blocks could contribute to representation of this theme: Youngstown GrovelandBrostem Reservoir; Dune Point-Bindloss-Empress Terraces-Remount; South Saskatchewan River Canyon-Middle Sand Hills; Lower Bow-Purple Springs Dunes and Pakowki Lake (Table 28). The targets for this theme can probably be met from within these blocks.

Recommendation: Focus on the Youngstown Groveland-Brostem Reservoir Block, the Dune Point-Bindloss-Empress Terraces Block, the Lower Bow-Purple Springs Dunes Block and the Pakowki Lake Block to ensure representation of this theme across its range of variation.

- Exposed slope: To meet the Level 1 NHT targets, about $41 \mathrm{~km}^{2}$ of this theme are required. Several blocks could contribute to representation of this theme: Dune Point-BindlossEmpress Terraces-Remount; South Saskatchewan River Canyon-Middle Sand Hills and Sage Creek-Milk River Canyon (Table 28).

Recommendation: Focus on the South Saskatchewan River Canyon-Middle Sand Hills Block and the Sage Creek-Milk River Canyon Block to ensure representation of this theme across its range of variation.

- Protected slope: Level 1 NHT targets for this theme have been met, however, they were achieved from sites located in the southern half of the subregion. A block that could contribute to a wider representation of this theme is the Dune Point-Bindloss-Empress Terraces-Remount Block (Table 28).

Recommendation: Focus on the Dune Point-Bindloss-Empress Terraces-Remount Block to ensure representation of this theme across its range of variation.

- Floor/Stream: To meet the Level 1 NHT targets, about $72 \mathrm{~km}^{2}$ of this theme are required. Several blocks could contribute to representation of this theme: Dune Point-BindlossEmpress Terraces-Remount; South Saskatchewan River Canyon-Middle Sand Hills and Sage Creek-Milk River Canyon. The targets for this theme can probably be met from within these blocks (Table 28).

Recommendation: Focus on the Dune Point-Bindloss-Empress Terraces-Remount Block and the Sage Creek-Milk River Canyon Block to ensure representation of this theme across its range of variation.

- Springs: To meet the Level 1 NHT targets, about $2.3 \mathrm{~km}^{2}$ of this theme are required. Several blocks could contribute to representation of this theme: Dune Point-Bindloss-Empress Terraces-Remount; South Saskatchewan River Canyon-Middle Sand Hills; Pakowki Lake; Writing-On-Stone and Sage Creek-Milk River Canyon (Table 28). The targets for this theme can probably be met from within these blocks.. 
Recommendation: Focus on the Dune Point-Bindloss-Empress Terraces-Remount Block, the South Saskatchewan River Canyon-Middle Sand Hills Block and the Sage Creek-Milk River Canyon Block to ensure representation of this theme across its range of variation.

- Wet meadow: To meet the Level 1 NHT targets, about $9 \mathrm{~km}^{2}$ of this theme are required. Several blocks could contribute to representation of this theme: Youngstown GrovelandBrostem Reservoir; Native Prairie (Major Lake); Pakowki Lake and Sage Creek-Milk River Canyon (Table 28). The targets for this theme can probably be met from within these blocks.

Recommendation: Focus on the Youngstown Groveland-Brostem Reservoir Block and the Sage Creek-Milk River Canyon Block to ensure representation of this theme across its range of variation.

- Shallow marsh: To meet the Level 1 NHT targets, about $2.4 \mathrm{~km}^{2}$ of this theme are required. Several blocks could contribute to representation of this theme: Youngstown GrovelandBrostem Reservoir; Native Prairie (Major Lake) and Pakowki Lake (Table 28). The targets for this theme can probably be met from within these blocks.

Recommendation: Focus on the Youngstown Groveland-Brostem Reservoir Block and the Pakowki Lake Block to ensure representation of this theme across its range of variation.

- Deep marsh: To meet the Level 1 NHT targets, about $2.5 \mathrm{~km}^{2}$ of this theme are required. Two blocks could contribute to representation of this theme: Lower Bow-Purple Springs Dunes and Pakowki Lake (Table 28). The targets for this theme might be met from within these blocks.

Recommendation: Focus on both blocks to ensure representation of this theme.

- Alkali wetland: To meet the Level 1 NHT targets, about $10 \mathrm{~km}^{2}$ of this theme are required. Several blocks could contribute to representation of this theme: Youngstown GrovelandBrostem Reservoir; Native Prairie (Major Lake); Dune Point-Bindloss-Empress TerracesRemount; Pakowki Lake and Sage Creek-Milk River Canyon (Table 28). The targets for this theme can probably be met from within these blocks of land.

Recommendation: Focus on the Dune Point-Bindloss-Empress Terraces-Remount Block and the Pakowki Lake Block to ensure adequate representation of this theme across its range of variation. 


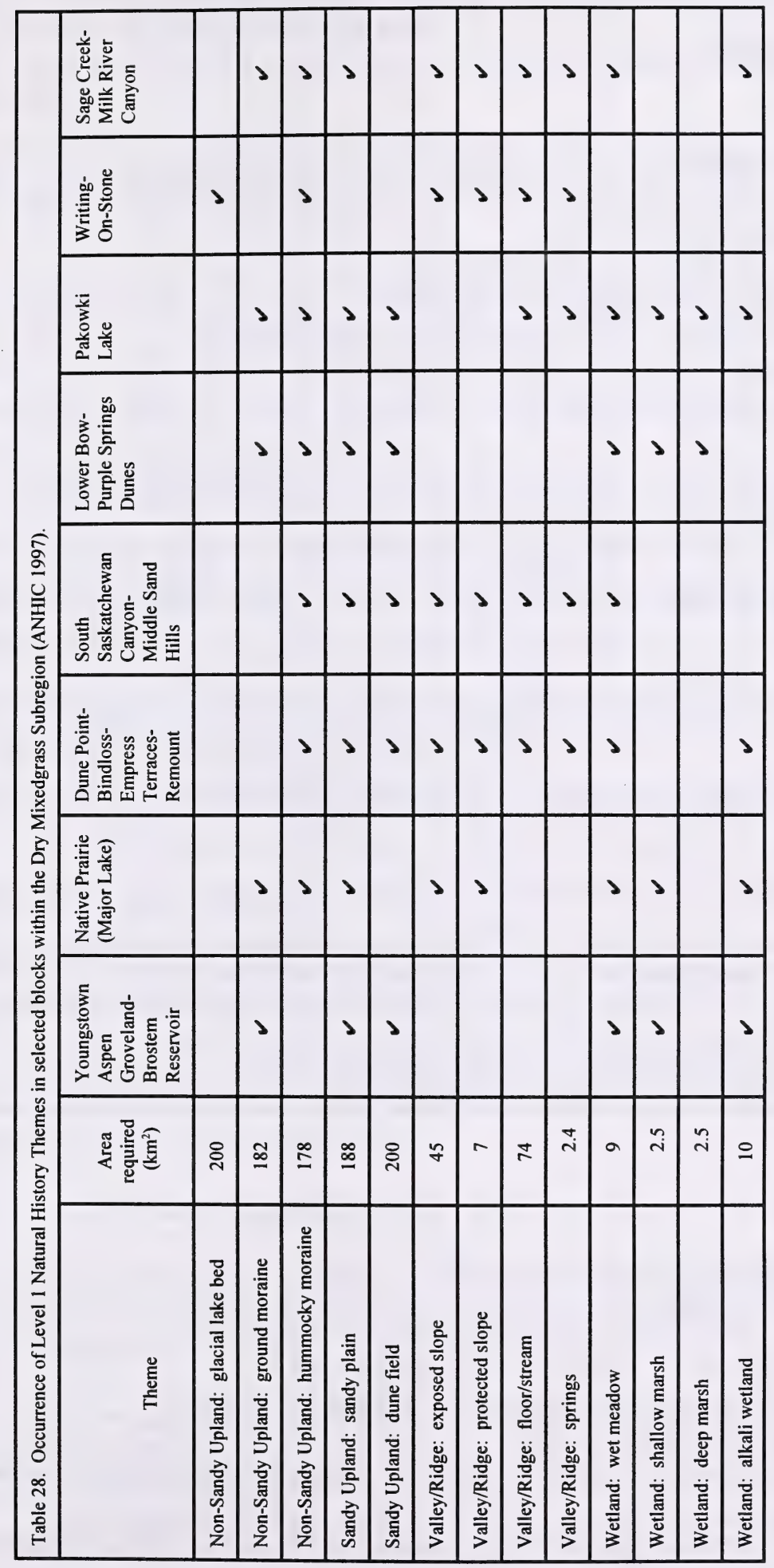




\section{Chapter 2.5 Filling the Gaps in the Foothills Fescue Subregion}

\section{Size and Land Ownership}

- The subregion covers about $15000 \mathrm{~km}^{2}$.

- The majority $(88 \%)$ is privately owned (Table 29$)$.

- Only about $2.4 \%$ is composed of provincial crown land.

- Federal crown lands consist of 7\% of the area, in three Indian Reserves.

- About $2.2 \%$ of the lands are categorized as "mixed" ownership.

- There are small areas of "water" and "other."

Table 29. Land ownership within the Foothills Fescue Subregion.

\begin{tabular}{|c|c|c|}
\hline Category & Land area $\left(\mathrm{km}^{2}\right)$ & Percent of total (\%) \\
\hline Crown - provincial & 357 & 2.4 \\
\hline Crown - federal* & 1044 & 7.0 \\
\hline Freehold & 13035 & 87.6 \\
\hline Mixed & 330 & 2.2 \\
\hline Other & 4.25 & 0.03 \\
\hline Water** & 116 & 0.8 \\
\hline Total & 14885 & 100 \\
\hline \multicolumn{2}{|c|}{$\begin{array}{l}\text { NOTE: The size of the subregion reported in Report 3 (Alberta Environmental Protection } 1994 \mathrm{~b}) \text { is } 14888.27 \\
\text { km². The discrepancy of 3.1 km² is due to the varying levels of precision between the land ownership and the } \\
\text { natural region GIS coverages. } \\
* \text { Federal crown lands include three Indian Reserves (Peigan, Blood, Eden Valley). } \\
\text { ** a GIS calculation of all waterbodies with an area of } 1.5 \mathrm{~km}^{2} \text { or larger }\end{array}$} \\
\hline
\end{tabular}

\section{General Comments}

- This is a highly disturbed subregion and includes:

- most of the City of Calgary

- many towns (eg. Airdrie, Nanton, Pincher Creek and Cardston)

- major stretches of Highway 2 and associated developments

- stretches of other main highways (Highways 1,3,5 and 2)

- farming and ranching as major land uses

- Has the highest density of roads of the four grassland subregions (excluding wellsite roads) (Figure 4).

- Has a relatively high percentage of primary and secondary roads (road density is discussed in detail in Chapter 1.5 of this report). 
- From the native prairie coverage (Table 30 ), about $10687 \mathrm{~km}^{2}(72 \%)$ of the subregion has half or less remaining in native prairie.

- Data are lacking on the amount of native vegetation remaining for about $11 \%$ of the subregion.

Table 30. Amount of land $\left(\mathrm{km}^{2}\right)$ per category of remaining native prairie within the Foothills Fescue Subregion.

\begin{tabular}{|c|c|c|c|c|c|c|}
\hline \multirow[b]{2}{*}{ Category } & \multicolumn{2}{|c|}{ Land area $\left(\mathrm{km}^{2}\right)$} & \multirow{2}{*}{ QSec + Twp. } & \multirow{2}{*}{$\begin{array}{c}\text { Percent of } \\
\text { Sub-total } \\
(\%)\end{array}$} & \multirow{2}{*}{$\begin{array}{l}\text { Total } \\
\left(\mathrm{km}^{2}\right)\end{array}$} & \multirow{2}{*}{$\begin{array}{c}\text { Percent } \\
\text { of total } \\
(\%)\end{array}$} \\
\hline & QSec* & Twp.** & & & & \\
\hline $76-100 \%$ & 2026 & 18 & 2044 & 14 & \multirow{2}{*}{2580} & \multirow{2}{*}{17} \\
\hline $51-75 \%$ & 339 & 197 & 536 & 3 & & \\
\hline $26-50 \%$ & 551 & 543 & 1094 & 7 & \multirow{4}{*}{10687} & \multirow{4}{*}{72} \\
\hline $1-25 \%$ & 1277 & --- & 1277 & 9 & & \\
\hline $0-25 \%$ & --- & 6296 & 6296 & 42 & & \\
\hline $0 \%$ & 2020 & --- & 2020 & 14 & & \\
\hline data unavailable & & & 1621 & 11 & 1621 & 11 \\
\hline Total & 6213 & 7054 & 14888 & 100 & 14888 & 100 \\
\hline \multicolumn{7}{|c|}{$\begin{array}{l}\text { * QSec - quarter section level native prairie GIS coverage } \\
\text { ** Twp. - township level native prairie GIS coverage }\end{array}$} \\
\hline
\end{tabular}

\section{Protected Areas and ESAs}

- Contains two protected areas larger than $10 \mathrm{~km}^{2}$ - Fish Creek Provincial Park $\left(11.89 \mathrm{~km}^{2}\right)$ and Ross Lake Natural Area $\left(19.43 \mathrm{~km}^{2}\right)$.

- About $8 \mathrm{~km}^{2}$ of Fish Creek Provincial Park are within the subregion.

- Additional protected areas in the subregion smaller than $10 \mathrm{~km}^{2}$ are listed in Table 19.

- A total of 26 ESAs has been identified which occur wholly or partially within the subregion (Map C, back pocket). These include:

- 2 internationally significant ESAs: Crowsnest River and Oldman River-Brocket.

- 7 nationally significant ESAs: Carway Iris, Lower Belly River, Milk River Ridge-Unglaciated, Paine-Beaverdam, Ross Lake Unglaciated, St. Mary Reservoir, Whaleback.

- 17 provincially significant ESAs: Bluestem, Bow River, Canon Coulee, Coulee Ridges, Glenwoodville Erratic, Lower St. Mary River, Lynch Lakes, Milk River Ridge-North East, Milk River Ridge-North West, Milk River Ridge-Northeast Slope, Milk River Ridge Reservoir, North Fork Milk River-A, Oldman River-Porcupine Hills, Pine Ridge, Porcupine Hills, Todd Creek Ridge, Upper St. Mary River. 
- There are also several regionally significant ESAs identified for the subregion.

- Most of the ESAs are composed of private land.

- Two ESAs are entirely special features, Glenwoodville Erratic and Milk River Ridge-Unglaciated.

- Significant portions of the Ross Lake Unglaciated and North Fork Milk River-A ESAs also include special themes.

\section{Targets and Prospects for Protection}

The target for protection of Level 1 Natural History Themes is adequate representation of 12 Natural History Themes, which total a minimum of $270 \mathrm{~km}^{2}$, or $1.8 \%$ of the subregion (Table 21 ). To date, approximately $7.8 \%$ of the target has been achieved. With such a small portion of the subregion remaining as crown land $(2.4 \%)$, and most of the subregion no longer with native prairie, the sites to choose as possible protected areas are limited.

Map D (back pocket) illustrates the pattern of native prairie remaining in the subregion. The largest blocks remaining are in the Milk River Ridge area and along the slopes of the Porcupine Hills. Small blocks are scattered along the western boundary of the subregion, up to about Township 16. The more-detailed quarter-section information is not available for the area north of Nanton, but the township data suggest that there is little or no native vegetation remaining.

A query of the land ownership data shows that there are eight contiguous blocks of crown land (excluding Indian Reserves) $10 \mathrm{~km}^{2}$ or larger (Map E, back pocket). Of these, two are flooded by reservoirs - the St. Mary and Oldman. One block in the Ross Lake area and four along the slopes of the Porcupine Hills make these important as protected area candidates in the Foothills Fescue Subregion.

Ideally a system of protected areas should represent an ecosystem, or natural subregion, across its range of variation (Cooperrider 1994). This objective will clearly not be met for the Foothills Fescue Subregion. There are no significant opportunities for the full northern portion of the subregion as there is little or no native vegetation remaining and essentially no crown land. The largest parcel is two sections in size in T29-R25-W4M (Map 8). A review of aerial photographs of the site shows it to be heavily disturbed.

For this subregion, remaining parcels of crown land within ESAs or in contiguous parcels of 10 $\mathrm{km}^{2}$ or greater have been divided into ten blocks (Map 8). Each block will be discussed, starting with those located in the south and moving north. The focus will be on identifying those parcels with remaining natural habitat or important ecological values. Because of the level of development, all such pieces are likely significant for conservation. The Level 1 NHTs will be discussed, but it is unlikely that any targets can be achieved. 


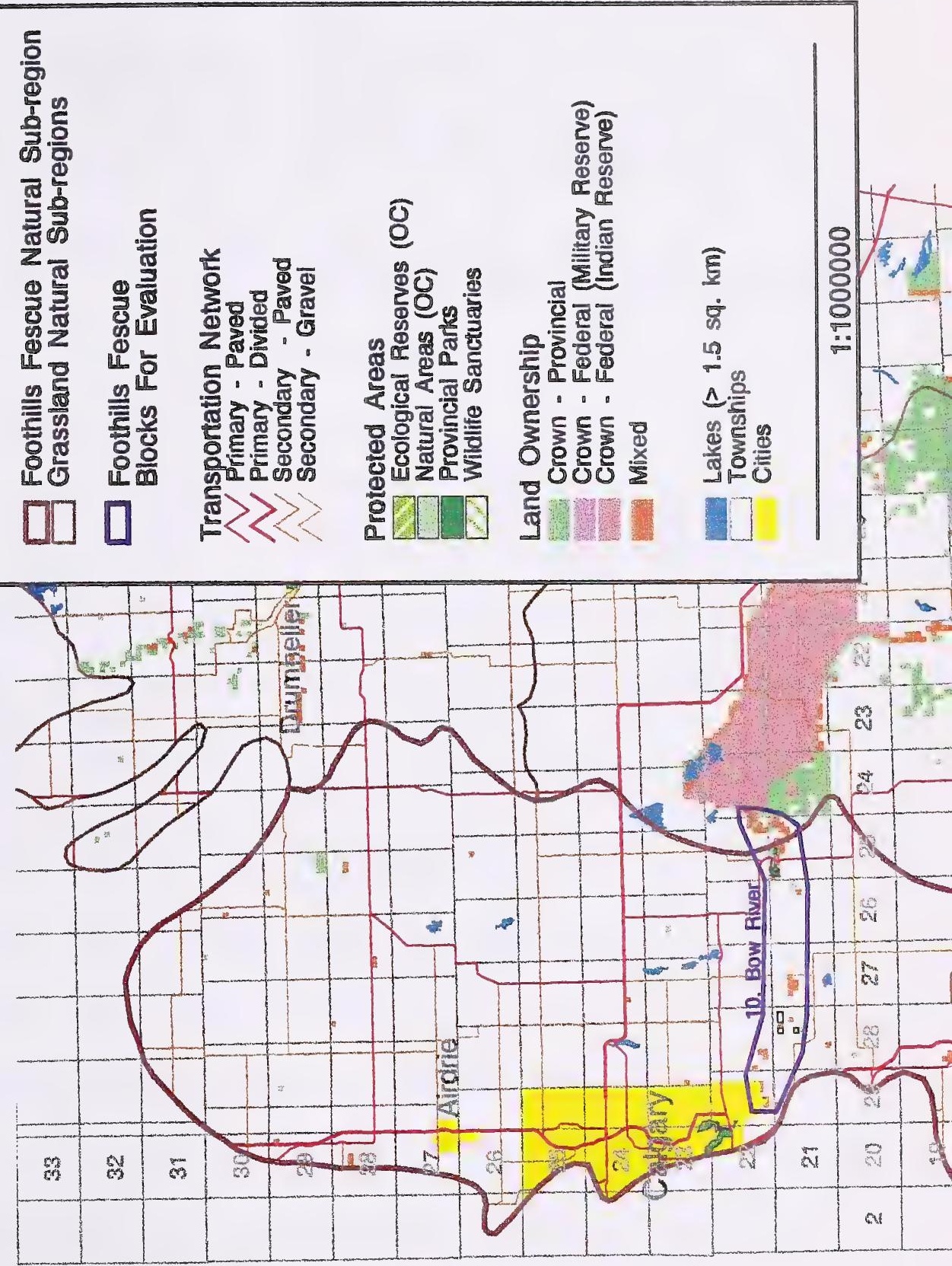




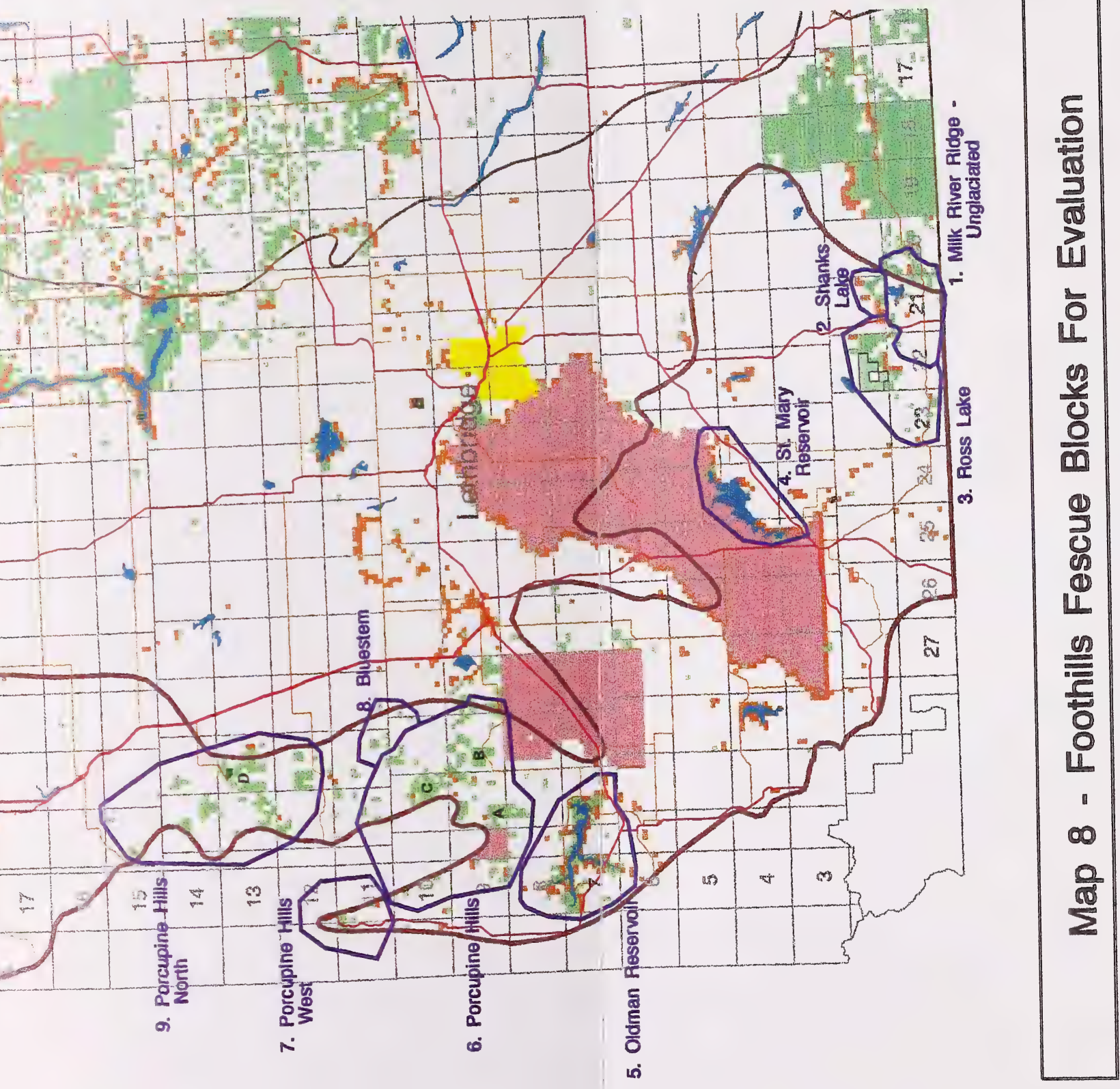




\subsection{Milk River Ridge-Unglaciated Block}

- Scattered quarters of crown land in T1-R20, 21, 22-W4M fall within the nationallysignificant Milk River Ridge-Unglaciated ESA (Map C, back pocket).

- The block includes land in both the Foothills Fescue and Mixedgrass Subregions, but as the main part of the ESA is within the Foothills Fescue Subregion, it is discussed here.

- Includes the following ESA:

\section{Milk River Ridge-Unglaciated (nationally significant)}

- ESA is about $90 \%$ within the Foothills Fescue Subregion, with the remainder within the Mixedgrass Subregion.

- The entire ESA is considered a special theme.

- Composed of twelve small, scattered parts.

- Little crown land occurs within the ESA.

- Biophysical features include:

- unglaciated plateau of the Milk River Ridge, south of the Milk River

- numerous priority plant species, including: tufted hymenopappus (Hymenopappus filifolius, S1S2), hare-footed locoweed (Oxytropis lagopus, S2) and intermediate hawk's-beard (Crepis intermedia, S2)

- disjunct populations of Clouded Parnassian Butterflies (Parnassius phoebus)

- There is one parcel of contiguous crown land bigger than $10 \mathrm{~km}^{2}$ that includes examples of the Milk River Ridge-Unglaciated landscape:

- in the Mixedgrass Subregion (Map 8).

- in the highest native prairie class (76-100\% native vegetation - Map D, back pocket).

- bisected by Highway 501 .

- Insect studies have found this site to be "highly significant," representing "an endemic prairie fauna that has been largely eliminated" (Hamilton 1995).

\section{Potential for contributing to Level One Natural History Theme representation:}

- The features within the Milk River Ridge ESA are all considered part of a special theme (ANHIC 1997).

- The crown land parcels are generally small and discontinuous and so do not contribute to the representation of any Level 1 NHTs.

- The parcel within the Mixedgrass Subregion includes portions of the unglaciated landscapes.

- These lands are outside the ESA and so the Level 1 NHTs within it have not been evaluated.

- They may, however, contribute to alkali wetland and hummocky moraine themes for the Mixedgrass Subregion (Shetsen 1987).

- The main value of the parcel is the presence within it of examples of the unglaciated landscapes and the endemic prairie insect fauna. 


\section{Considerations:}

- All crown land parcels within this block should be considered for establishment as a protected area.

- Some of the parcels are within a nationally significant ESA and include special features such as portions of the unglaciated plateau and may include rare species.

- The ESA is composed of disjointed parcels. Adjacent crown lands outside the ESA should also be considered for protected area status to help maintain ecological integrity.

- The area with endemic prairie insect fauna (Section 18-T1-R20-W4M) appears to be significant (Hamilton 1995) and the parcel it is within should be considered for protected area status.

\subsection{Shanks Lake Block}

- This block is composed primarily of scattered parcels near Shanks Lake in T2-R21-W4M (Map 8). It stretches along the south slopes of the North Milk River within the North Fork Milk River B ESA (Cottonwood Consultants 1987d).

\section{North Fork Milk River-B ESA (regionally significant)}

- An extensive grassland and incised valley with some sandstone outcrops.

- A large ESA of which only a very small portion is crown land.

- Biophysical features include:

- key habitat for Pronghorn (Yellow B-listed by AEP 1996)

- erratics of the McNeill Erratics Train (special theme)

- potential for nesting birds of prey on rock outcrops

- St. Mary River Shorthead Sculpin (rare fish, S1T-ranked by ANHIC)

- habitat for Yellow-bellied Marmot

\section{Potential for contributing to Level One Natural History Theme representation:}

- The crown land parcels are too small and discontinuous to contribute to the representation of Level 1 NHTs.

\section{Considerations:}

- This site is important functionally in maintaining a corridor of native habitat along the North Milk River and includes special features.

- All crown portions should be considered for establishment as a protected area.

\subsection{Ross Lake Block}

- This block is primarily in Township 2, Range 22 (Map 8), with some scattered parcels in T1R23-W4M.

- All the crown lands are within the 76 to $100 \%$ native prairie class (Map D, back pocket). 
- The Ross Lake Natural Area makes up part of the block.

- The parcel of contiguous crown land that includes the Ross Lake Natural area is about 42 sq. $\mathrm{km}$. in size, not including "mixed" lands. This is the largest remaining parcel of crown land in the Foothills Fescue Subregion.

- Includes the following ESAs:

\section{(a) Ross Lake Unglaciated (nationally significant)}

- ESA is entirely within the subregion.

- Composed of three scattered parts.

- Most of the land in the ESA is in the highest class of native prairie (76-100\% native vegetation - Map $D$, back pocket).

- About half the ESA is crown land, most of which is already included in the Ross Lake Natural Area.

- Biophysical features include:

- unglaciated plateau of the Milk River Ridge, north of the Milk River

- numerous priority plant species, including: tufted hymenopappus (Hymenopappus filifolius, S1S2), hare-footed locoweed (Oxytropis lagopus, S2), intermediate hawk'sbeard (Crepis intermedia, S2), Raymond's sedge (Carex raynoldsii, S2) and fewflowered rush (Juncus confusus, S2)

- disjunct populations of clouded Parnassian butterflies (Parnassius phoebus)

- sensitive bird species, including: Baird's Sparrow (YeLlow A-listed by AEP 1996)

- lightly grazed and unglaciated foothills grassland on the Ross Lake Community Pasture

\section{(b) North Fork Milk River A (provincially significant)}

- ESA is entirely within the subregion.

- There are small, scattered parcels of crown land within the ESA and one parcel bigger than $10 \mathrm{~km}^{2}$.

- Biophysical features include:

- moderately incised valley with sandstone outcrops

- moderate density of nesting birds of prey, including Ferruginous Hawk (BLUE-listed by AEP 1996; vulnerable rating by COSEWIC) and Golden Eagle (YELLOW B-listed by AEP 1996)

- historic nest site of Peregrine Falcon (RED-listed by AEP 1996; endangered rating by COSEWIC)

- habitat for Yellow-bellied Marmot

- St. Mary River Shorthead Sculpin (rare fish, S1T-ranked by ANHIC)

- priority plant species, including: western blue flag (Iris missouriensis, S1S2), Cusick's paintbrush (Castilleja cusickii, S2) and hare-footed locoweed (Oxytropis lagopus, S2)

- remnant of preglacial erosional surface at U.S. boundary in Sections 1, 2, 11 and 12 in T1-R23-W4M 


\section{Potential for contributing to Level One Natural History Theme representation:}

- There are several scattered crown land parcels too small and discontinuous to contribute to the representation of Level 1 NHTs.

- The parcel of land that includes the Ross Lake Natural Area and possible additions to it is the largest remaining parcel of provincial crown land within the subregion:

- includes portions of two ESAs

- potential for contributing to the following Level 1 NHTs:

- Ross Lake Unglaciated: ground moraine, hummocky moraine, special themes

- North Fork Milk River A: ground moraine, hummocky moraine, special themes.

\section{Considerations:}

- All crown lands in this block should be maintained in their natural state.

- All crown lands adjoining the Ross Lake Natural Area should be considered for incorporation into the natural area. This would significantly improve the long-term viability of the site and protect sections of provincially and nationally significant ESAs. This would also increase the representation of several Level 1 NHTs.

- One scattered quarter-section (SW 36-T1-R23-W4M), although small, is within the nationally significant Ross Lake Unglaciated ESA. SW 36 should also be considered for protected area status to protect this special theme.

- Section 11-T1-R23-W4M includes a portion of the remnant preglacial erosional surface (Cottonwood Consultants 1987d). This section should be considered for a protected area in recognition of the special features it includes.

\subsection{St. Mary Reservoir Block}

- This block is made up of small parcels of crown land centred on T4-R24-W4M (Map 8).

- The lands are within the following ESAs:

(a) St. Mary Reservoir (nationally significant)

- All of the ESA is within the subregion.

- Biophysical features include:

- a large reservoir on the St. Mary River

- waterfowl staging and production area

- colony of Double-crested Cormorants (YELLOw B-listed by AEP 1996)

- particularly noteworthy for waterfowl production is a slough on the south side of the reservoir in Sections 22 and 23-T4-R24-W4M

\section{(b) Upper St. Mary River (provincially significant)}

- All of the ESA is within the subregion.

- The bed and shore of the river are crown lands, the remainder is private land except the $0.3 \mathrm{~km}^{2}$ Woolford Provincial Park (South Country Protected Areas Project 1993)

- Biophysical features include:

- extensive riparian narrow-leaved cottonwood and shrubbery 
- diverse breeding bird populations

- ungrazed woodland at Woolford Provincial Park, including rare plants

- key White-tailed Deer habitat

- colony of Great Blue Herons (Yellow B-listed by AEP 1996) in Section 5T3-R24-W4M

- canyon and rock outcrops in Coal Canyon area

- good section of Pleistocene deposits in Section 16-T1-R25-W4M

- St. Mary River Shorthead Sculpin (rare fish, S1T-ranked by ANHIC)

\section{(c) Lower St. Mary River (provincially significant)}

- Approximately $40 \%$ of the ESA is within the subregion

- Biophysical features include:

- grassy and rocky valley of the St. Mary River

- massive rock outcrops with abundant ammonite fossils

\section{Potential for contributing to Level One Natural History Theme representation:}

- The adjoining crown land parcels are too small and discontinuous to contribute to the representation of Level 1 NHTs.

\section{Consideration:}

- All crown lands in this block and those scattered along the Upper and Lower St. Mary rivers should be maintained in their natural state.

\subsection{Oldman Reservoir Block}

- A block of crown land in T7-R29,30-W4M and in T7-R1-W5M, primarily underlying the Oldman Reservoir (Map 8).

- Detailed information is unavailable, but from the township data, is appears that the area is less than $25 \%$ native prairie (Map D, back pocket).

- Bisected by a number of roads.

- Includes scattered crown land in two ESAs, as follows:

(a) Oldman River-Brocket (internationally significant)

- About two-thirds of the ESA is within the subregion.

- Biophysical features include:

- part of Canada's most extensive narrow-leaved and balsam poplar riparian woodland, shrubbery and moist channel habitats

- diverse breeding bird habitat

- eroding slopes with priority plants, including: rush-pink (Stephanomeria runcinata, S2)

- extensive hoodoo cliffs of eroding till

- excellent Pleistocene geological sections

- key Mule Deer and White-tailed Deer habitat 
- nesting Prairie Falcons (Yellow A-listed by AEP 1996)

- minor vegetated sand dunes at the edge of the valley on the uplands south of the river

- productive fishery.

(b) Oldman River-Porcupine Hills (provincially significant)

- this ESA is completely within the subregion.

- Occurs primarily on private land.

- Biophysical features include:

- extensive balsam poplar riparian woodland and shrubbery

- diverse rock outcrops, slump blocks, grassland, shrub thickets and Douglas fir woodland along slopes

- diverse breeding bird populations

- prime quality fisheries

\section{Potential for contributing to Level One Natural History Theme representation:}

The adjoining crown land parcels are too small and discontinuous to contribute to the representation of Level 1 NHTs.

\section{Considerations:}

- All crown lands in this block should be maintained in their natural state.

- Lands within the internationally significant Oldman River-Brocket ESA should be considered for a protected area in recognition of their significant features.

\subsection{Porcupine Hills Block}

- Includes three of the six parcels of crown land $10 \mathrm{~km}^{2}$ or larger remaining in the subregion (Sites A, B, and C-Map 8).

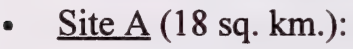

- outside the area of detailed native prairie information, but the township digital database shows it as primarily in a township with greater than $75 \%$ native prairie.

- a long, narrow shape with some private land inholdings.

- $\underline{\text { Site B }}$ (10.5 sq. km.):

- also in an area shown to be greater than $75 \%$ native prairie.

- bisected by secondary Highway 735, likely reducing its effective size to below 10 sq. $\mathrm{km}$.

- $\quad$ Site C (25.5 sq. km.):

- the detailed (quarter section) digital data show the site to be greater than $75 \%$ native prairie.

- a long, narrow shape with some private land inholdings.

- adjacent to crown lands in the Montane portion of the Porcupine Hills.

- adjacent Montane lands connect to a southern parcel of crown land also in the Foothills Fescue Subregion. 
- The lands are within the following ESA:

\section{Porcupine Hills ESA (provincially significant)}

- Roughly $90 \%$ of the ESA is in the subregion.

- Includes small patches of cultivation and logging.

- Includes the internationally significant archeological site at Head-Smashed-In World Heritage Site.

- Biophysical features include:

- diverse montane ridges with massive sandstone outcrops,

- lush fescue grassland and forb communities, low and tall shrubbery, and open Douglas fir and limber pine woodland

- dense forests of Engelmann spruce, lodgepole pine, Douglas fir and aspen at higher elevations

- beaver dam complexes along major valleys

- highest elevations in the northwestern portion were unglaciated

- priority plant species, including: whitlow-wort (Draba reptans, S2) and Geyer's onion (Allium geyeri, $\mathrm{S} 2$ )

- diversity of breeding bird species

- several pairs of nesting Prairie Falcons (YelLOw A-listed by AEP 1996)

- habitat for Cooper's Hawk (YELLow B-listed by AEP 1996) and Cassin's Finch (status undetermined by AEP 1996)

- key Mule Deer and, at higher elevations, key Elk habitat

- Yellow-bellied Marmots in sandstone outcrops

- extensive areas of lightly grazed fescue grassland

- dancing grounds of Sharp-tailed Grouse (YELLOw A-listed by AEP 1996)

\section{Potential for contributing to Level One Natural History Theme representation:}

- The three parcels of crown land $10 \mathrm{~km}^{2}$ or larger in this block are all within the Porcupine Hills ESA.

- Site B is likely too small to contribute to representation of Level 1 themes once disturbances associated with Secondary Highway 785 are excluded.

- Sites A and C could potentially contribute to the following Level 1 NHTs: hummocky moraine, ground moraine, protected slope, exposed slope, floor/stream.

\section{Considerations:}

- All crown lands in this block should be maintained in their natural state.

- All contiguous parcels of crown land should be considered for establishment as protected areas.

- The Foothills Fescue portions, although made up of contiguous lands, are themselves fragmented. Adjacent crown lands in the montane subregion of the Porcupine Hills should also be considered for inclusion in a protected area to increase the viability of the sites. 


\subsection{Porcupine Hills West Block}

- This site is not within an ESA, but appears on Map E (back pocket) as one of the few contiguous parcels of crown land $10 \mathrm{~km}^{2}$ or larger in the subregion .

- Bisected by Highway 22 and has some cultivated portions.

Potential for contributing to Level One Natural History Theme representation:

- Crown lands that are still in native vegetation are scattered and the remaining area of contiguous crown land is too small to contribute toward representation of Level 1 NHTs.

\section{Considerations:}

- All crown lands in this area should be maintained in their natural state.

- Although this site superficially appears to be a possible candidate for a protected area, it is bisected by Highway 22 and interrupted with non-native vegetation. On its own, the site does not merit protected area status, but could be added to adjacent montane sites, if any are under consideration.

\subsection{Bluestem Block}

- There are five scattered parcels of crown land within the provincially significant Bluestem ESA (Map C, back pocket).

- Much of the site is over $75 \%$ native vegetation.

- Crown land is scattered along the Oldman River and west of Fort Macleod.

- Includes the following ESA:

\section{Bluestem ESA (provincially significant)}

- About half of the ESA is within the subregion.

- Biophysical features include:

- coarse glacial lake, outwash and till deposits

- diversity of mixed grassland and foothills grassland types

- silverberry and thorny buffaloberry shrubbery, and fescue and wheatgrass grassland interspersed with drainages and small alkali ponds

- widespread patches of little bluestem (Schizachyrium scoparium, S2) grassland vegetation; some in excellent condition

- abundant ground squirrel populations - food source and feeding area for birds of prey including Prairie Falcon (YeLlow a-listed by AEP 1996), Golden Eagle (YELlow B-listed by AEP 1996) and Ferruginous Hawk (BLUE-listed by AEP 1996; vulnerable rating by COSEWIC)

- glacial erratics of the Foothills Erratics Train (special theme). 


\section{Potential for contributing to Level One Natural History Theme representation:}

- The adjoining crown land parcels are too small and discontinuous to contribute to the representation of Level 1 NHTs.

\section{Consideration:}

- As the site is within a provincially significant ESA and includes special features, all crown lands in this area should be considered for establishment as a protected area.

\subsection{Porcupine Hills North Block}

- The remaining parcels of crown land along the slopes of the Porcupine Hills, north of Secondary Highway 520 are included in this block (Map 8).

- Includes Site D (Map 8), one of the parcels of crown land $10 \mathrm{~km}^{2}$ or larger:

- comprises three almost-contiguous pieces that total about 41 sq. $\mathrm{km}$.

- the largest parcel in the subregion, after Ross Lake.

- includes Willow Creek Provincial Park.

- areas of $50 \%$ of less native prairie (Map D, back pocked) fragment this parcel.

- Lands within this block are primarily within the following ESA:

\section{North Porcupine Hills ESA (regionally significant)}

- About $80 \%$ of the ESA is within the subregion.

- Biophysical features include (Cottonwood Consultants 1989):

- diverse montane ridge and valley habitats

- key ungulate range

- dancing grounds of sharp-tailed grouse (YELLOw A-listed by AEP 1996)

- beaver pond complexes

- diversity of breeding birds

\section{Potential for contributing to Level One Natural History Theme representation:}

These lands are not in a provincial or better ESA and so the Level 1 NHTs have not been evaluated. They may however contribute to: ground moraine, hummocky moraine, floor/stream, protected slope and exposed slope themes (Shetsen 1987).

\section{Considerations:}

- All crown lands in this block should be maintained in their natural state.

- Crown lands in parcel "D" should be considered for establishment as a protected area.

- Although not $10 \mathrm{sq} . \mathrm{km}$ in size, there are other parcels of crown land that, for the subregion, are of significant size and should be considered for protected areas. 


\subsection{Bow River Block}

- Comprises scattered parcels of crown land along the Bow River. They show as "Mixed" on Map 8 because the crown land and patented land are interfingered.

- The majority of the provincial crown land in the block are in this subregion, so it will be discussed here.

- Includes the following ESA:

\section{Bow River ESA (provincially significant)}

- Approximately $50 \%$ of the ESA is within the subregion; $50 \%$ is in the Mixedgrass Subregion

- Most of the ESA is in the Siksika Reserve, but small portions of crown land occur to the west of the Reserve along the river.

- Includes the proposed Carseland Natural Area (Protective Notation).

- The large block of crown land southwest of the Siksika Reserve is cultivated land.

- Biophysical features include:

- narrow natural corridor along shallow river valley

- extensive riparian woodland and shrubbery

- high diversity of breeding birds

- ungrazed riparian woodland islands

- habitat for Pileated Woodpecker (YELLOW B-listed by AEP 1996)

- colony of Great Blue Herons (YELLOW в-listed by AEP 1996)

- $\quad$ white spruce stands on north-facing slopes

- major waterfowl staging and production area

- $\quad$ habitat for Double-crested Cormorants (YELLOw B-listed by AEP 1996)

\section{Potential for contributing to Level One Natural History Theme representation:}

- The adjoining crown land parcels are too small and discontinuous to contribute to the representation of Level 1 NHTs.

\section{Considerations:}

- All crown lands in this block should be maintained in their natural state.

- Assess further those provincial crown lands containing special features (e.g., Great Blue Heron colony, important bird habitats) for consideration as a protected area.

- The proposed Carseland Natural Area includes important biophysical features, but would be difficult to establish due to interfingering with private lands. 


\section{Meeting the Level 1 Natural History Theme Targets}

Excluding those underlying reservoirs, there are only five parcels of crown land in the Foothills Fescue Subregion larger than the $10 \mathrm{~km}^{2}$ minimum size criteria. These parcels are distributed as follows: three in the Porcupine Hills Block (Sites A, B and C-Map 8), one in the Porcupine Hills North Block (Site D) and one in the Ross Lake Block. As indicated in Table 31, the Level 1 NHTs present in the Porcupine Hills and Ross Lake ESAs are ground moraine, hummocky moraine, exposed slope, protected slope and floor/stream. Although levels may be close for ground moraine and hummocky moraine, no Level 1 NHT targets will be met, even if all these parcels were established as protected areas. 


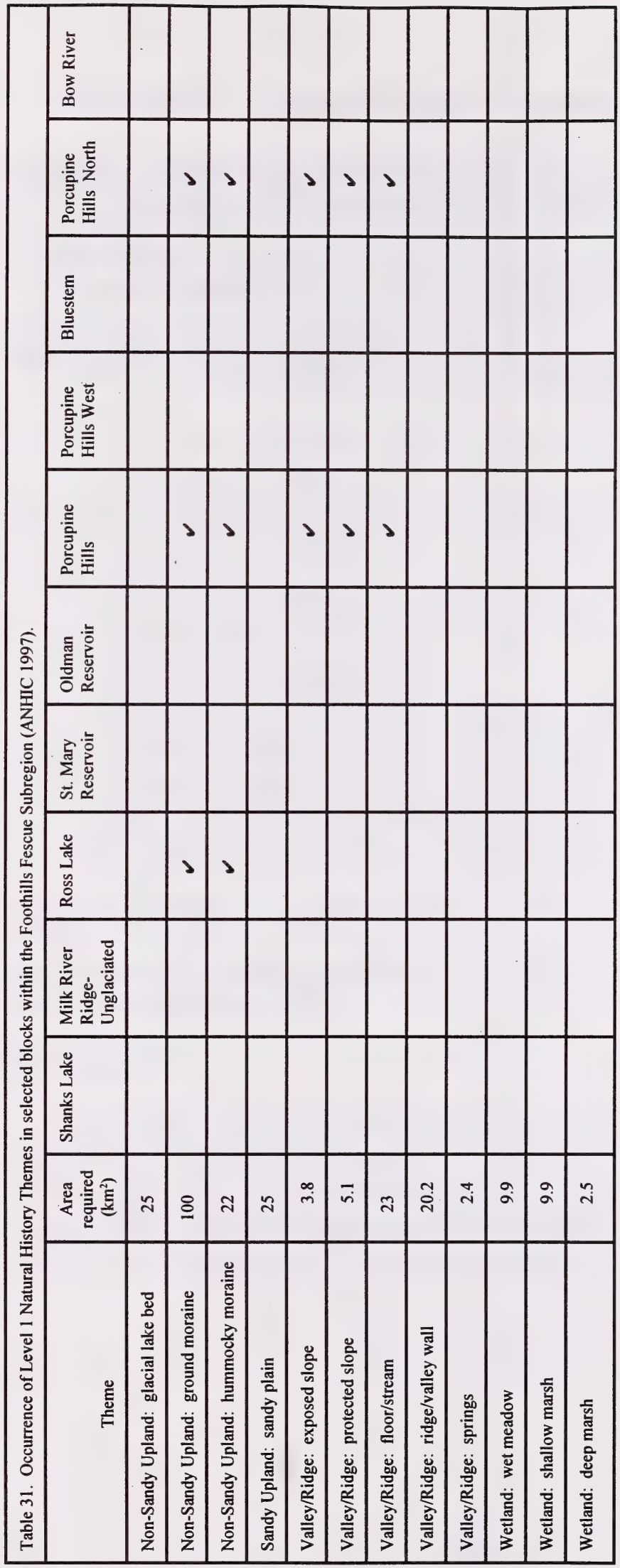




\section{Chapter 2.6 Filling the Gaps in the Northern Fescue Subregion}

\section{Size and Land Ownership}

- Subregion covers about $15000 \mathrm{~km}^{2}$.

- Majority (about $75 \%$ or $11469 \mathrm{~km}^{2}$ ) of the subregion is privately owned (Table 32 ).

- About $20 \%\left(3027 \mathrm{~km}^{2}\right)$ of its lands are crown (Table 32). Of the crown land in the subregion, about $79 \%\left(2398 \mathrm{~km}^{2}\right)$ consists of contiguous areas more than $10 \mathrm{~km}^{2}$ in size (GIS calculations).

- In total, about $5.7 \%\left(870 \mathrm{~km}^{2}\right)$ of the lands in the subregion are categorized as "mixed" $\left(99 \mathrm{~km}^{2}\right)$, "other" ( $\left.312 \mathrm{~km}^{2}\right)$ and "water" $\left(459 \mathrm{~km}^{2}\right)$, (Table 32).

Table 32. Land ownership within the Northern Fescue Subregion.

\begin{tabular}{|c|c|c|}
\hline Category & Land area $\left(\mathrm{km}^{2}\right)$ & Percent of total (\%) \\
\hline Crown & 3027 & 19.7 \\
\hline Freehold & 11469 & 74.6 \\
\hline Mixed & 99 & 0.7 \\
\hline Other & 312 & 2.1 \\
\hline Water** & 459 & 2.9 \\
\hline Total & 15368 & 100 \\
\hline
\end{tabular}

NOTE: The size of the subregion reported in Report 3 (Alberta Environmental Protection 1994b) is 15384.61 $\mathrm{km}^{2}$. The discrepancy of $16.2 \mathrm{~km}^{2}$ is due to differences in the level of precision between the land ownership and natural region GIS coverages.

Land ownership figures were generated from LSAS quarter-section data, adjusted using 1:250,000 lake coverage.

**a GIS calculation of all waterbodies with an area of $1.5 \mathrm{~km}^{2}$ or larger.

\section{General Comments}

- Much of subregion is highly disturbed and fragmented, and includes:

- Drumheller as the largest city.

- many towns and villages (e.g., Castor, Coronation, Consort).

- farming and ranching as major land uses.

- Traversed by several highways (e.g., Highway 9, 56, 26, 41 and 12).

- Second-highest road density of the four grassland subregions, at $0.61 \mathrm{~km} / \mathrm{km}^{2}$ (Table 5).

- Second-highest wellsite density of the four grassland subregions, at 0.86 wellsites $/ \mathrm{km}^{2}$ (Table 9). Some of the highest wellsite densities occur within T35-R6-W4M and T37-R7-W4M.

- About 3\% (about $497 \mathrm{~km}^{2}$ ) of the subregion has more than $76 \%$ of its native prairie remaining (Table 33). Significant blocks of native prairie in this category remain in the Rumsey, Little Fish Lake and Bodo-Altario areas (Map D, back pocket). 
- About $22 \%\left(3294 \mathrm{~km}^{2}\right)$ of the subregion has between 51 to $75 \%$ of its native prairie remaining (Table 33). Significant blocks of native prairie in this category remain in the Kirkpatrick Lake, Grassy Island Lake, Neutral Hills, Hand Hills, areas (Map D, back pocket).

- At least $48 \%\left(7420 \mathrm{~km}^{2}\right)$ of the subregion has less than half of its native prairie remaining (Table 33). There are no data available on the amount of native vegetation remaining for about $27 \%\left(4173 \mathrm{~km}^{2}\right)$ of the subregion. Likely, similar proportions of native prairie would be found in these areas.

Table 33. Amount of land $\left(\mathrm{km}^{2}\right)$ per category of remaining native prairie within the Northern Fescue Subregion.

\begin{tabular}{|c|c|c|c|}
\hline Category & Land area $\left(\mathrm{km}^{2}\right)$ & Sub-total (\%) & Total (\%) \\
\hline $76-100 \%$ & 497 & 3 & \multirow{2}{*}{25} \\
\hline $51-75 \%$ & 3294 & 22 & \\
\hline $26-50 \%$ & 4149 & 27 & \multirow{2}{*}{48} \\
\hline $0-25 \%$ & 3271 & 21 & \\
\hline Data unavailable & 4173 & 27 & 27 \\
\hline Total & 15384 & 100 & 100 \\
\hline
\end{tabular}

NOTE: Figures for the remaining native prairie were generated on a township basis for this subregion since quarter-section data were not available. Due to the precision levels of the data, especially the township data, figures are estimates only.

\section{Protected Areas and ESAs}

- Contains two protected areas larger than $10 \mathrm{~km}^{2}$ (Rumsey South Natural Area and Hand Hills Ecological Reserve)

- A total of 35 ESAs occurs wholly or partially within the subregion (Map C, back pocket). These include:

- 9 internationally significant ESAs: Chain-Farrell Lakes, Handhills Fescue, Handhills Lake, Kirkpatrick Native Prairie, Little Fish Lake, Pearl Lakes/Chain Lakes, Rumsey South, Spiers-Chain-Farrell Lakes, Willow Creek.

- 7 nationally significant ESAs: Battle River-Bigknife, Battle River-Brownfield, Grassy Island Lake, Grassy Island Native Prairie, Silver Heights, Sullivan Lake, Tolman Badlands.

- 19 provincially significant ESAs: Bodo, Dowling Lake, Ensleigh Lakes, Esther/Douglas Lake Native Prairie, Gooseberry Lake, Gough Lake, Handhills, Lanes Lake, Marion-Shooting Lakes, Middle Lakes, Muddy Buttes, Mudspring Lake, Neutral Hills, Paintearth, Rumsey North, Sounding Dunes, Sounding Lake, Wintering Hills, Youngstown Aspen Groveland. 


\section{Targets and Prospects for Protection}

The target for protection of Level 1 Natural History Themes is adequate representation of 14 Natural History Themes, which total a minimum of $447 \mathrm{~km}^{2}$, or $2.91 \%$ of the subregion. To date, approximately $31 \%$ of the target has been achieved within two protected areas (Table 22). Given the level of disturbance that has occurred within this subregion, it may be difficult to achieve adequate representation of all of the NHTs across their range of variation. Areas with the greatest potential to contribute to NHT representation are those blocks of intact prairie greater than $10 \mathrm{~km}^{2}$ in size, many of which have been identified as ESAs. The following discussion addresses each of these areas in detail. Their location is shown on Map 9.

\subsection{Hand Hills Block}

- Much of the area has $75 \%$ or more remaining in native prairie.

- This block "stands out as the finest example of fescue grassland remaining in terms of the extent of continuous lush fescue grassland" (Wershler and Wallis 1990). "It is also the only sizeable tract of fescue grassland located on loamy soil" (ibid., p12).

- $22 \mathrm{~km}^{2}$ of the block has been established as the Hand Hills Ecological Reserve.

- 61 ha on the east side of Little Fish Lake is established as Little Fish Lake Provincial Park.

- Adjoins the Dorothy East Block (see discussion of this block in Chapter 2.7).

- A diversity of grazing regimes, from light to heavy.

- Includes the following ESAs:

(a) Handhills Fescue (internationally significant)

- ESA is entirely within the subregion

- Biophysical features include:

- extensive area of lush fescue grassland

- contains part of the largest area of northern fescue grassland left in North America (Geowest Environmental Consultants 1996).

- significant populations of sensitive bird species, including: Upland Sandpiper (YELLOw A-listed by AEP 1996) and Baird's Sparrow (YeLLow A-listed by AEP 1996)

- priority plant species, including: crowfoot violet (Viola pedatifida, S2)

- dancing grounds of Sharp-tailed Grouse (YeLLOw A-listed by AEP 1996)

- aspen clones provide nesting habitat for Merlins, an uncommon species in the region but GREEN-listed for the province (AEP 1996b)

\section{(b) Handhills Lake (internationally significant)}

- ESA is entirely within the subregion

- Biophysical features include:

- most productive lake in Alberta for Piping Plover (RED-listed by AEP 1996; endangered rating by COSEWIC)

- extensive mudflats provide significant habitat for shorebirds

- significant staging area for waterfowl (Geowest Environmental Consultants 1996). 
(c) Little Fish Lake (internationally significant)

- ESA is entirely within the subregion

- Biophysical features include:

- shallow and slightly saline lake

- significant breeding area for Piping Plover (RED-listed by AEP 1996; endangered rating by COSEWIC)

- significant shorebird area

- waterfowl production and staging lake (Geowest Environmental Consultants 1996).

\section{(d) Handhills (provincially significant)}

- ESA is entirely within the subregion

- Biophysical features include:

- aspen woodlands, tall and low shrubbery, and grasslands on west and north slopes of the Hand Hills

- some remnants of natural vegetation on the plateau

- tertiary conglomerate and gravel cap, an uncommon geological feature

- disjunct populations of Cordilleran plant species, including: heart-leaved buttercup (Ranunculus cardiophyllus) and squawroot (Perideridia gairdneri)

- north-facing slopes along the top edge of the escarpment have small stands of paper birch, a species that is unusual in the region although common in the province

- springs and marl deposits

- diverse breeding bird habitats

(e) Willow Creek (internationally significant)

- ESA is entirely within the subregion

- Biophysical features include:

- steep-walled coulees

- upland northern mixed grassland, some of which is in excellent condition (may be best in Alberta)

- diverse coulee features including badlands, alkali springs, aspen woodlands and tall and low shrub communities

- diverse breeding bird habitats, including nesting habitat for birds of prey such as Prairie Falcon (YELLOw A-listed by AEP 1996) and Ferruginous Hawk (BLUE-listed by AEP 1996; vulnerable rating by COSEWIC)

- Blocks of contiguous crown land greater than $10 \mathrm{~km}^{2}$ occur within and next to identified ESAs in this area.

- Both the Handhills Lake and Handhills ESA have only small segments of crown land within them, but are near large blocks of crown land to the south.

\section{Potential for contributing to Level 1 Natural History Theme representation:}

Crown lands within this block have excellent potential for contributing to the following Level 1 NHTs, most of which are under-represented within existing protected areas: 


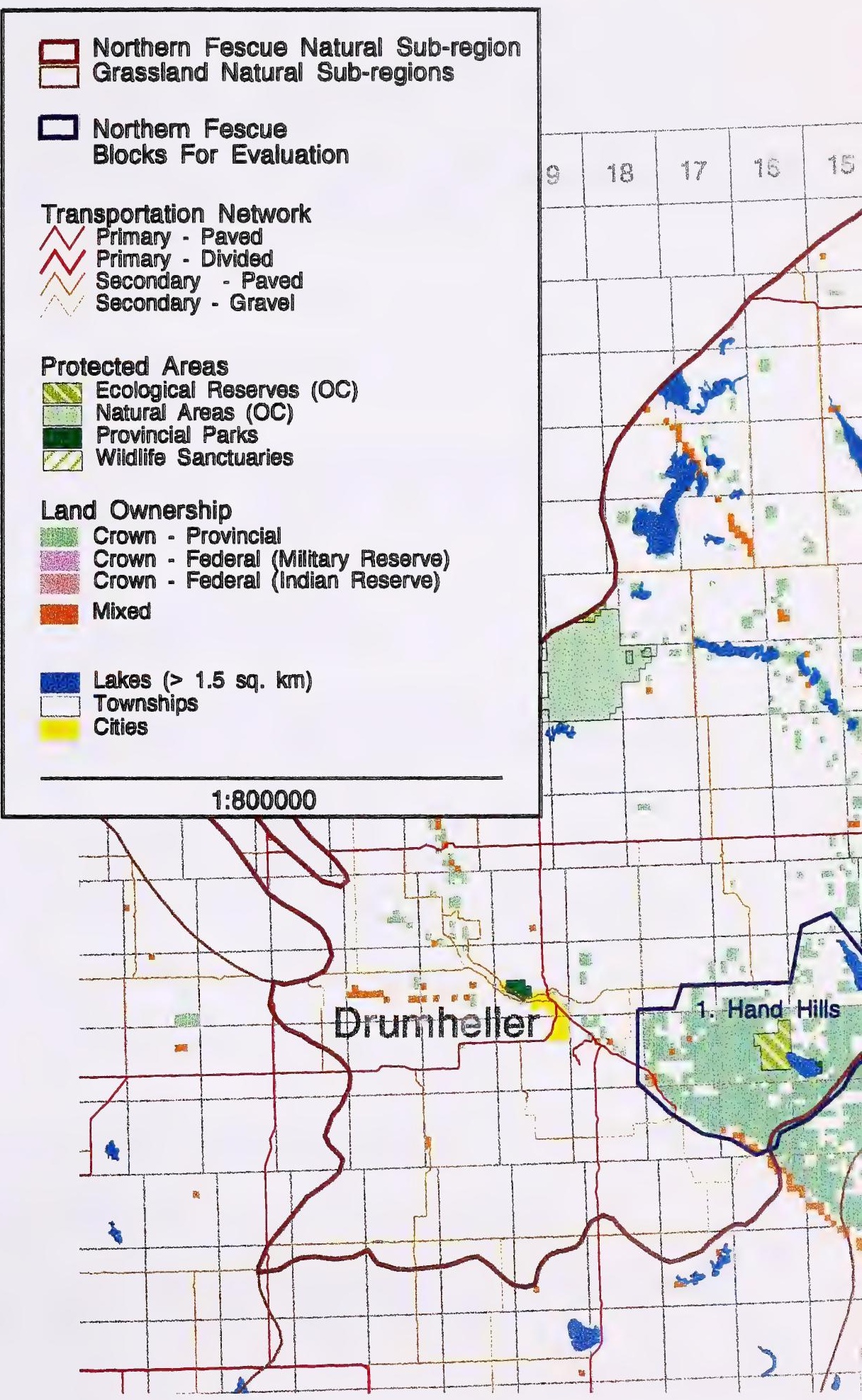




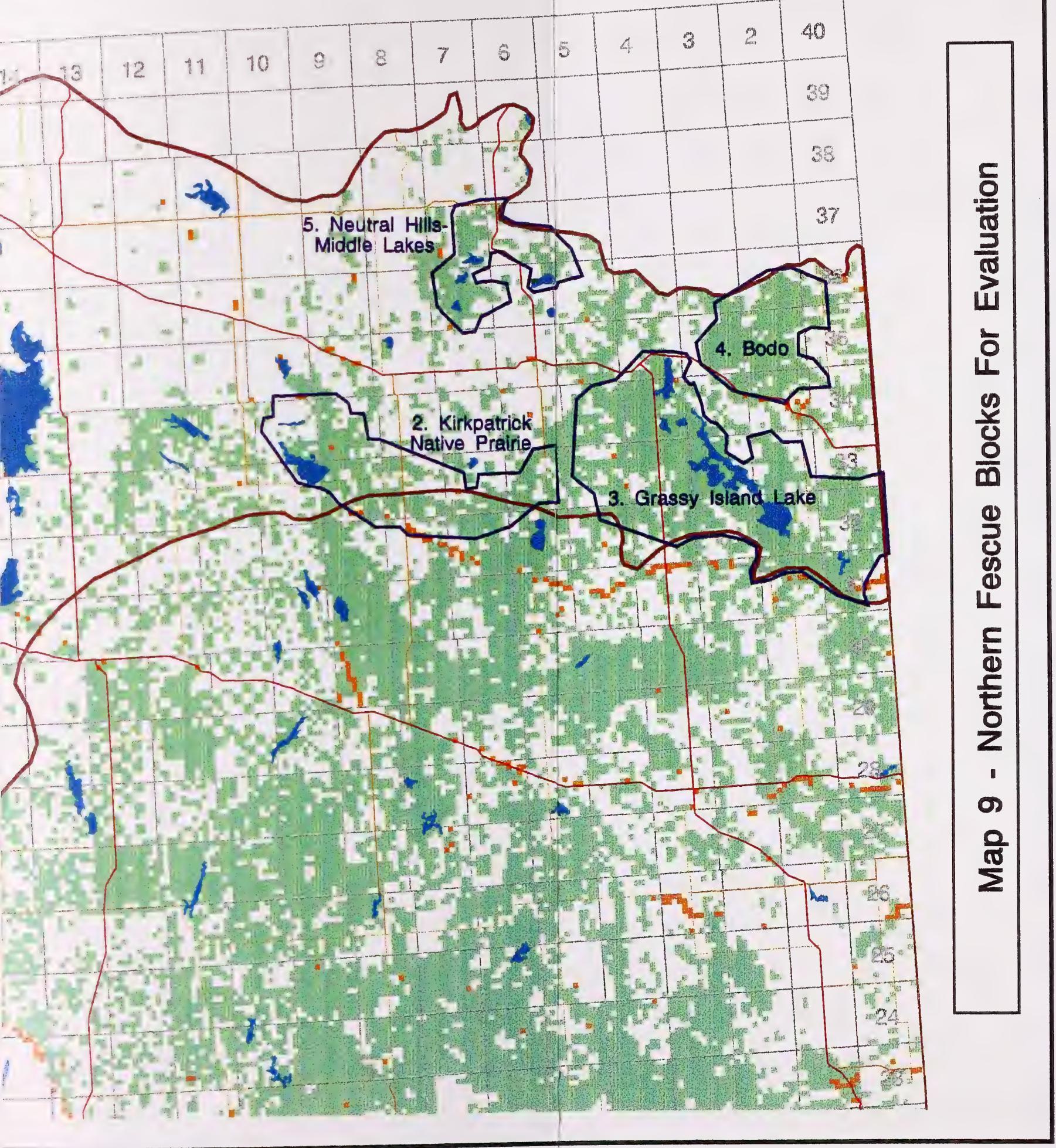


- Handhills Lake ESA: ground moraine, sandy plain, springs, wet meadow, alkali wetland, lake.

- Handhills ESA: ground moraine, exposed slope, protected slope, floor/stream, springs, wet meadow.

- Handhills Fescue ESA: ground moraine, hummocky moraine, sandy plain, exposed slope, protected slope, floor/stream, wet meadow and shallow marsh.

- Little Fish Lake ESA: ground moraine, hummocky moraine, alkali wetland, lake.

-Willow Creek ESA: ground moraine, hummocky moraine, sandy plain, exposed slope, protected slope, floor/stream, springs, wet meadow, shallow marsh.

\subsection{Kirkpatrick Native Prairie Block}

- Most of the area has $50-75 \%$ remaining in native prairie.

- Includes some patches of cultivation.

- Contains lightly grazed areas.

- Contains the Kirkpatrick Lake Bird Sanctuary, a nationally significant site.

- The block includes land in both the Northern Fescue and Dry Mixedgrass Subregions, but will be discussed in this section.

- Includes the following ESA:

\section{Kirkpatrick Native Prairie (internationally significant)}

- ESA is about two-thirds within the subregion.

- Biophysical features include:

- significant fescue prairie communities

- "excellent habitat for terrestrial breeding birds and high potential for rare avian species" (Geowest Environmental Consultants 1996).

- dune systems

- mixture of solonetzic, sandy and loamy soils

- productive creek valley, with grassland and some parkland on the adjacent upland

- beaver ponds, moist meadows, willow and aspen along the creek.

- diversity of breeding birds, including: Baird's Sparrow (YELLOw A-listed by AEP 1996)

- Kirkpatrick Lake is a significant waterfowl production and staging lake

- significant upland habitat

- small ephemeral ponds around its perimeter (Geowest Environmental Consultants 1996).

- Blocks of contiguous crown land greater than $10 \mathrm{~km}^{2}$ occur within and next to identified ESAs, particularly extending eastward from Kirkpatrick Lake.

\section{Potential for contributing to Level 1 Natural History Theme representation:}

Crown lands within this block have excellent potential for contributing to the following Level 1 NHTs, most of which are under-represented within existing protected areas: 
- Kirkpatrick Native Prairie ESA: ground moraine, sandy plain, dune field, floor/stream, wet meadow, alkali wetland.

\subsection{Grassy Island Lake Block}

- Much of the area has $50-75 \%$ remaining in native prairie.

- Includes some cultivated areas.

- Contains areas exposed to varying grazing intensities.

- Includes the following ESAs:

(a) Grassy Island Native Prairie (nationally significant)

- ESA is about $95 \%$ within the subregion.

- Biophysical features include:

- extensive grassland communities (including rough fescue) that are reasonably undisturbed

- significant Mule Deer and White-tailed Deer habitat

(b) Grassy Island Lake (nationally significant)

- ESA is entirely within the subregion.

- Biophysical features include:

- large lake basin

- lakes in this block are significant waterfowl production and staging areas

(c) Muddy Buttes (provincially significant)

- ESA is entirely within the subregion.

- Biophysical features include:

- prominent ice thrust ridge rising $100 \mathrm{~m}$ above the surrounding grassland

- small areas of badlands, ravines and springs

- fescue grassland on undulating to rolling terrain

- populations of Baird's Sparrow (YELLOW A-listed by AEP 1996)

(d) Esther/Douglas Lake Native Prairie (provincially significant)

- ESA is about $90 \%$ within the subregion.

- Area is a transition zone for northern fescue and dry mixed prairie.

- Biophysical features include:

- the highest concentration in the region of Sharp-tailed Grouse (YELLOw A-listed by AEP 1996) dancing grounds

- Blocks of contiguous crown land greater than $10 \mathrm{~km}^{2}$ occur within and next to ESAs in this area.

\section{Potential for contributing to Level 1 Natural History Theme representation:}

Crown lands within this block have good potential for contributing to the following Level 1 NHTs, most of which are under-represented within existing protected areas: 
- Grassy Island Native Prairie ESA: glacial lake bed, ground moraine, hummocky moraine, sandy plain, dune field, exposed slope, protected slope, floor/stream, wet meadow, alkali wetland.

- Grassy Island Lake ESA: glacial lake bed, hummocky moraine, sandy plain, springs, wet meadow, alkali wetland, lake.

- Muddy Buttes ESA: ground moraine, hummocky moraine, exposed slope, protected slope, wet meadow.

- Esther/Douglas Lake Native Prairie ESA: hummocky moraine, sandy plain, springs, wet meadow, shallow marsh, alkali wetland.

\subsection{Bodo Block}

- Most of the area has more than $50 \%$ remaining in native prairie.

- Area is a transition zone between the southern groveland edge of the Central Parkland and the Northern Fescue Subregion.

- Contains fescue grassland, mixed grassland and aspen groveland on rolling hummocky moraine.

- Some cultivated areas.

- Areas under varying grazing intensities.

- A large block of contiguous crown land greater than $10 \mathrm{~km}^{2}$ occurs within this area.

- Includes the following ESA:

\section{Bodo (provincially significant)}

- ESA is entirely within the subregion.

- Biophysical features include:

- lush fescue grasslands

- aspen woodlands, shrub communities

- alkali springs

- strongly hummocky terrain with typical knob and kettle topography

- major ice thrust ridges

- more than 200 plant and more than 50 bird species recorded

- priority plant species

- dancing grounds of Sharp-tailed Grouse (YelLow A-listed by AEP 1996)

- nesting habitat for Upland Sandpiper (YeLLow A-listed by AEP 1996), Baird's Sparrow (YeLlow A-listed by AEP 1996) and Cooper's Hawk (Yellow B-listed by AEP 1996)

\section{Potential for contributing to Level 1 Natural History Theme representation:}

Crown lands within this block have excellent potential for contributing to the following Level 1 NHTs, most of which are under-represented within existing protected areas:

- Bodo ESA: hummocky moraine, wet meadow, shallow marsh and alkali wetland. 


\subsection{Neutral Hills-Middle Lakes Block}

- Most of the area has between $50-75 \%$ remaining in native prairie.

- A transition zone between parkland in the north and prairie to the south.

- $0.5 \mathrm{~km}^{2}$ of land on the northwest shore of Gooseberry Lake established as a provincial park.

- Some of the area is cultivated.

- Parts of the area are heavily grazed.

- Contains one site under land use reservation as a proposed Natural Area - Gooseberry Lake (Protective Notation).

- Includes the following ESAs:

(a) Neutral Hills (provincially significant)

- ESA is entirely within the subregion.

- Biophysical features include:

- diversity of landforms, including prominent ice-thrust ridges

- grasslands interspersed with aspen groves

- diversity of vegetation types

- highly diverse habitat for terrestrial breeding birds

(b) Middle Lakes (provincially significant)

- ESA is entirely within the subregion.

- Biophysical features include:

- significant shorebird habitats

- diverse alkali wetlands

- waterfowl production and migration area

(c) Gooseberry Lake (provincially significant)

- ESA is entirely within the subregion.

- Biophysical features include:

- significant breeding area for Piping Plovers (RED-listed by AEP 1996; endangered rating by COSEWIC)

- staging habitat for shorebirds

- evidence of ice-thrust ridges

- grasslands interspersed with aspen groves

- Large blocks of contiguous crown land greater than $10 \mathrm{~km}^{2}$ occur within this area, particularly on the western end of the Neutral Hills and within or next to the Middle Lakes ESA.

\section{Potential for contributing to Level 1 Natural History Theme representation:}

Crown lands within this block have excellent potential for contributing to the following Level 1 NHTs, most of which are under-represented within existing protected areas:

- Neutral Hills ESA: hummocky moraine, sandy plain, exposed slope, protected slope, springs, wet meadow, shallow marsh, alkali wetland. 
- Middle Lakes ESA: hummocky moraine, springs, wet meadow, shallow marsh, alkali wetland, lake.

- Gooseberry Lake ESA: springs, wet meadow, alkali wetland, lake.

\section{Other Areas of Significance}

These are areas that are generally not large enough to contribute to the representation the Level 1 NHTs, yet have been recognized for their biophysical significance.

\section{A. The Spiers/Chain/Farrell/Pearl Lakes Complex}

- Complex contains internationally significant ESAs.

- Entire complex is within the subregion.

- Small portions of crown land connect some of the lakes.

- Excluding the lakes, the amount of crown land available is too small and discontinuous to contribute to the representation of Level 1 NHTs.

- Biophysical features include:

- shallow alkali lakes that periodically dry up

- grassy meadows and alkali springs on adjacent lands

- staging areas for migrating shorebirds

- nesting habitat at Spiers Lake for Piping Plover (RED-listed by AEP 1996; endangered rating by COSEWIC)

- waterfowl production and staging at Farrell Lake and middle Chain Lakes

- significant populations in backshore areas of Baird's Sparrow (YELLOW A-listed by AEP 1996)

\section{Considerations:}

- Maintain all remaining crown land within this complex in a natural state.

- All crown land parcels, particularly those containing special features, should be considered for establishment as protected areas in recognition of their international significance.

\section{B. Rumsey South}

- Site is an internationally significant ESA.

- Approximately $90 \%$ of the ESA is within the subregion.

- Most of the block was established as the $144 \mathrm{~km}^{2}$ Rumsey South Natural Area in 1996.

- Includes small patches of cultivation.

- Varying levels of grazing intensities.

- Biophysical features include:

- relatively undisturbed aspen woodland, lush fescue grassland and a variety of shrubbery and ephemeral wetlands

- classic moraine plateaux and eskers 
- sensitive bird species, including: Baird's Sparrow (YeLLow A-listed by AEP 1996), Upland Sandpiper (YELLOw A-listed by AEP 1996) and Cooper's Hawk (YELLow B-listed by AEP 1996)

- waterfowl production areas in wetter years

- priority plant species, including: crowfoot violet (Viola pedatifida, S2)

- dancing grounds of Sharp-tailed Grouse (YELLow A-listed by AEP 1996)

\section{Consideration:}

- Consider adding adjacent small parcels of crown land to the existing Rumsey South Natural Area that could contribute to representation of Level 1 NHTs .

\section{Sullivan Lake}

- Site is a nationally significant ESA.

- The entire ESA is within the subregion.

- Small areas of crown land are scattered around the perimeter of the lake. The largest block (about 300 ha) is situated on the southeast side.

- Biophysical features include:

- a large alkali lake

- some native grasslands and badlands next to the lake

\section{Considerations:}

- Excluding the lake, the amount of crown land available in this area is too small and discontinuous to contribute to the representation of Level 1 NHTs.

- Including the lake, the site could make significant contributions to the "lake" and "alkali wetland" NHTs. Consider establishing the bed and shore of the lake and its remaining adjacent crown lands as a protected area.

\section{Battle River-Big Knife and Battle River-Brownfield}

- Sites are nationally significant ESAs.

- Both ESAs are entirely within the subregion.

- Little crown land occurs in these ESAs.

- Contains one site under land use reservation as a proposed Natural Area - Lorraine (Protective Notation).

- Biophysical features include:

- glacial spillway channel (i.e., Battle River valley)

- diversity of habitats (e.g., white spruce stands)

- badlands and oxbow lakes

- riparian woodlands and shrublands

- springs and wet meadows

- major slump blocks with perched wetlands

- abandoned nesting colony of Great Blue Herons (Yellow B-listed by AEP 1996) 


\section{Consideration:}

- Maintain all remaining crown land within this complex in a natural state.

- Consider establishing the Lorraine site and other remaining crown lands as protected areas in recognition of their national significance.

\section{E. Tolman Badlands}

- Site is a nationally significant ESA.

- Approximately $50 \%$ of the ESA is within the subregion.

- Small portions of crown land are scattered along the Red Deer River along the length of the ESA.

- Biophysical features include:

- rugged badlands and significant bedrock exposures

- rare mesa-like formations

- grasslands, sagebrush flats, aspen woodlands and dense white spruce forests

- riparian forests and springs

- diversity of plant species

- sensitive bird species, including: Pileated Woodpecker (YeLLow в-listed by AEP 1996) and Loggerhead Shrike (YELLOw A-listed by AEP 1996; threatened rating by COSEWIC)

- duck staging and goose production area

- prime nesting habitat for birds of prey, including: Prairie Falcon (YeLlOw A-listed by AEP 1996), Golden Eagle (YELLOw в-listed by AEP 1996), Cooper's Hawk (YELLOw B-listed by AEP 1996) and Ferruginous Hawk (BLUE-listed by AEP 1996; vulnerable rating by COSEWIC)

- historic nesting areas for Peregrine Falcon (RED-listed by AEP 1996; endangered rating by COSEWIC)

\section{Considerations:}

- Maintain all remaining crown land within this ESA in a natural state.

- Assess further those crown lands containing special features (e.g., landforms, habitats for uncommon birds, springs) for possible establishment as protected areas.

\section{F. Paintearth}

- Site is a provincially significant ESA.

- Approximately $50 \%$ of the ESA is within the subregion.

- Little crown land occurs in this ESA within the subregion.

- The most productive, least disturbed habitat is in the western area.

- Patchy cultivation is found throughout the area, with ongoing clearing.

- Includes the candidate Paintearth Natural Area (SW 20, 29, S30 and SW 32-T39-R15-W4M).

- Coal mining activities adjacent to the natural area. 
- Biophysical features include:

- picturesque and extensive badlands

- diverse badlands with a mixture of grassland, aspen woods and scattered spruce

- extensive willow shrubbery, some poplar and paper birch woodland

- beaver ponds along the stream courses

- diversity of breeding birds, including sensitive species such as the Rock Wren (YELLOW в-listed by AEP 1996)

\section{Considerations:}

- Maintain all remaining crown land within this ESA in a natural state.

- Consider establishing the candidate Paintearth Natural Area.

\section{G. Lanes Lake}

- Site is a provincially significant ESA.

- The entire ESA is within the subregion.

- Little crown land is present within the ESA.

- Biophysical features within this area include:

- waterfowl production area in wet years

- sensitive and at risk bird species that occur in the dry, grassy lake-bottom habitats, including: Baird's Sparrow (Yellow A-listed by AEP 1996) and Sprague's Pipit (BLUE-listed by AEP 1996)

\section{Considerations:}

- Maintain all remaining crown land within this ESA in a natural state.

- Including the lake, the site could make significant contributions to the "deep marsh" NHT. Consider establishing the bed and shore of the lake and its remaining adjacent crown lands as a protected area.

\section{H. Marion/Shooting Lakes}

- Site is a provincially significant ESA.

- Approximately $50 \%$ of the ESA is within the subregion.

- Little crown land occurs in this ESA.

- Biophysical features include:

- staging, moulting and production wetlands for waterfowl, particularly Shooting Lake

- diverse wetlands (e.g., shallow sedge meadows, bulrush/cattail marshes, mudflats)

- presence in grassy backshore habitats of sensitive bird species, including: Baird's Sparrows (YELLOW A-listed by AEP 1996) and Upland Sandpipers (YeLlOw A-listed by AEP 1996)

- feeding habitat for Great Blue Herons (YeLLOw B-listed by AEP 1996)

- concentrations of terns and gulls 
- possible colony at Shooting Lake of Black-crowned Night-herons (YELLOw B-listed by AEP 1996)

- shorebird staging, especially at Marion Lake

- diversity of breeding marsh and shore birds

- hawthorn (Crataegus rotundifolia), a plant uncommon in the region, on islands in Marion Lake.

\section{Considerations:}

- Maintain all remaining crown land in a natural state.

- Assess further those crown lands containing special features (e.g., colonial water bird habitat, islands with hawthorn, alkali wetlands) for possible establishment as protected areas.

\section{Gough Lake}

- Site is a provincially significant ESA.

- The entire ESA is within the subregion.

- Small areas of crown land occur around the lake.

- Upland fescue grassland around the lake is heavily grazed.

- Biophysical features include:

- ephemeral, large, alkali lake

- productive waterfowl habitat in wet years

- numerous Baird's Sparrows (YeLlOw A-listed by AEP 1996) and Sprague's Pipits

(BLUE-listed by AEP 1996) in vegetated lake bottom and shore habitats during dry years

- variety of saline wetland plant communities

- occurrence of heliotrope (Heliotropium curassavicum), an uncommon plant in the region

\section{Considerations:}

- Maintain all remaining crown land within this ESA in a natural state.

- Including the lake, the site could make significant contributions to the "glacial lake bed," "wet meadow," "alkali wetland" and "lake" NHTs. Consider establishing the bed and shore of the lake and its remaining adjacent crown lands as a protected area.

\section{J. Dowling Lake}

- Site is a provincially significant ESA.

- The entire ESA is within the subregion.

- Small areas of crown land occur around the lake, primarily along the southern and eastern sides.

- Cultivation has fragmented some of the area.

- Biophysical features within this area include:

- large alkali lake surrounded by wetland complexes consisting of ephemeral marshes, wet meadows and alkali marshes 
- alkali springs that feed the lake (rare in the region)

- significant shorebird habitats (e.g., mudflats)

- evidence of nesting Piping Plovers (RED-listed by AEP 1996; endangered rating by COSEWIC)

\section{Considerations:}

- Maintain all remaining crown land within this ESA in a natural state

- Assess further those crown lands containing special features (e.g., alkali springs, nesting habitat for Piping Plover, alkali marshes) for consideration as an established protected area.

- Including the lake, the site could make significant contributions to the "wet meadow" and "alkali wetland" NHTs. Consider establishing the bed and shore of the lake and its remaining adjacent crown lands as a protected area.

\section{K. Mudspring Lake}

- Site is a provincially significant ESA.

- Approximately $95 \%$ of the ESA is within the subregion.

- Little crown land occurs around the lake.

- Biophysical features within this area include:

- alkali lake, alkali meadows, springs and soapholes

- waterfowl and shorebird staging area

- potential for rare plants in spring areas

- potential for Baird's Sparrows (YelLow A-listed by AEP 1996)

\section{Consideration:}

- Maintain all remaining crown land within this ESA in a natural state.

\section{Wintering Hills}

- Site is a provincially significant ESA.

- Approximately $90 \%$ of the ESA is within the subregion.

- Little crown land; mostly along the south side of the Red Deer River valley.

- Portions of the ESA may have $50-75 \%$ native prairie remaining.

- The southern part of the Hills has been converted to agriculture.

- Portions of the ESA have been impacted by coal-mining and gravel quarrying.

- According to Lamoureux et al. (1983), there are several important biophysical features within this area, including:

- gravel-capped hills that are remnants of the landscape surface that existed in the Tertiary period (major remnants of this landscape type are rare in Alberta)

- aspen and balsam poplar woodlands on north-facing slopes

- hummocky moraine fescue grasslands

- badland topography 


\section{Consideration:}

- Maintain all remaining crown land within this ESA in a natural state.

\section{Craig Lake-Bloor Lake Block}

- A large block of contiguous crown land greater than $10 \mathrm{~km}^{2}$ occurs within the Craig Lake/Bloor Lake area, about $20 \mathrm{~km}$ west of Kirkpatrick Lake.

- The entire area is within the subregion.

- No additional data is available for this site, however, the upland and wetland areas may have some potential for representation of Level 1 NHTs.

\section{Considerations:}

- Assess further those crown lands that may have potential for representation of Level 1 NHTs.

- Evaluate the area for its special biophysical features.

\section{Meeting Level 1 Natural History Theme Targets}

Considerations for meeting each of the Level 1 NHT targets are presented below. Although each is presented separately, potential protected areas may encompass more than one theme. To ensure maintenance of ecological integrity, representative areas ideally need to be greater than 10 $\mathrm{km}^{2}$ (where possible) and include representation of the themes across their range of variation. To ensure adequate representation of the region's biodiversity, several sites across the region need to be considered. Expanding current protected areas will ensure ecological integrity and is an effective way of meeting goals.

- Glacial lake bed: To meet the Level 1 NHT targets, $100 \mathrm{~km}^{2}$ of this theme are required. The only block with representation of this theme is Grassy Island Lake (Table 34). Two other sites, Gough Lake and Tolman Badlands, include small areas of glacial lake bed. They do not, however, include any parcels of crown land large enough to make a contribution to theme targets. It is unlikely that the targets for this theme can be met within those ESAs ranked as provincial or higher in significance.

Recommendation: Focus on the Grassy Island Lake Block for representation of this theme. In addition, consider protecting all available parcels of crown land that contain this theme.

- Ground moraine: To meet the Level 1 NHT targets, about $90 \mathrm{~km}^{2}$ of this theme are required. Three blocks could contribute to representation of this theme: Hand Hills, Kirkpatrick Native Prairie and Grassy Island Lake (Table 34). The targets for this theme can probably be met from within these blocks. 
Recommendation: Focus on the Hand Hills Block in the southwestern part of the subregion and the Grassy Island Lake Block in the eastern part to ensure representation of this theme across its range of variation.

- Hummocky moraine: Level 1 NHT targets for this theme have been met, however, they were achieved primarily from one protected area - Rumsey South Natural Area. Other blocks that could contribute to a wider representation of this theme include: Hand Hills, Grassy Island Lake, Bodo and Neutral Hills-Middle Lakes (Table 34).

Recommendation: Focus on the Hand Hills Block in the southwestern part of the subregion and the Bodo Block in the eastern part to ensure broader representation of this theme across its range of geographic variation.

\begin{tabular}{|c|c|c|c|c|c|c|}
\hline Theme & $\begin{array}{c}\text { Area } \\
\text { Required } \\
\left(\mathrm{km}^{2}\right)\end{array}$ & $\begin{array}{l}\text { Hand Hills } \\
\text { Block }\end{array}$ & $\begin{array}{l}\text { Kirkpatrick } \\
\text { Native Prairie } \\
\text { Block }\end{array}$ & $\begin{array}{l}\text { Grassy } \\
\text { Island Lake } \\
\text { Block }\end{array}$ & $\begin{array}{l}\text { Bodo } \\
\text { Block }\end{array}$ & $\begin{array}{l}\text { Neutral } \\
\text { Hills-Middle } \\
\text { Lakes Block }\end{array}$ \\
\hline Non-Sandy Upland: glacial lake bed & 100 & & & $\checkmark$ & & \\
\hline Non-Sandy Upland: ground moraine & 90 & $\checkmark$ & $\checkmark$ & 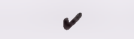 & & \\
\hline Non-Sandy Upland: hummocky moraine & 0 & $\bullet$ & . & $\checkmark$ & $\checkmark$ & $\checkmark$ \\
\hline Sandy Upland: sandy plain & 21 & $\checkmark$ & 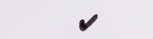 & $\checkmark$ & & $\boldsymbol{\sim}$ \\
\hline Sandy Upland: dune field & 25 & & $\checkmark$ & $\checkmark$ & & \\
\hline Valley/Ridge: exposed slope & 24 & $\checkmark$ & & $\checkmark$ & & 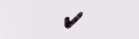 \\
\hline Valley/Ridge: protected slope & 9.4 & $\checkmark$ & & $\checkmark$ & & $\checkmark$ \\
\hline Valley/Ridge: floor/stream & 25 & $\checkmark$ & $\checkmark$ & $\checkmark$ & & \\
\hline Valley/Ridge: springs & 2.4 & $\checkmark$ & & $\bullet$ & & $\checkmark$ \\
\hline Wetland: wet meadow & 0 & $\bullet$ & $\checkmark$ & $\checkmark$ & 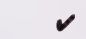 & $\checkmark$ \\
\hline Wetland: shallow marsh & 0 & $\sim$ & & $\checkmark$ & 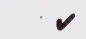 & $\checkmark$ \\
\hline Wetland: deep marsh & 0.7 & & & & & \\
\hline Wetland: alkali wetland & 0.7 & $\sim$ & $\bullet$ & 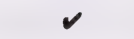 & $\checkmark$ & 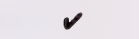 \\
\hline Wetland: lake & 10 & $\checkmark$ & $\checkmark$ & $\nu$ & & $\checkmark$ \\
\hline
\end{tabular}

- Sandy plain: To meet the Level 1 NHT targets, about $21 \mathrm{~km}^{2}$ of this theme are required. Four blocks can contribute to representation of this theme: Hand Hills, Kirkpatrick Native Prairie, Grassy Island Lake and the Neutral Hills-Middle Lakes Block (Table 34). The targets for this theme can probably be met from within these blocks.

Recommendation: Focus on the Kirkpatrick Native Prairie Block in the southern part of the subregion and the Grassy Island Lake Block in the eastern part to ensure representation of this theme across its range of variation. 
- Dune field: To meet the Level 1 NHT targets, about $25 \mathrm{~km}^{2}$ of this theme are required. Two blocks can contribute to representation of this theme: Kirkpatrick Native Prairie and Grassy Island Lake (Table 34). The targets for this theme can probably be met from within these two blocks.

Recommendation: Focus on both the Kirkpatrick Native Prairie and the Grassy Island Lake Blocks for representation of this theme.

- Exposed slope: To meet the Level 1 NHT targets, $24 \mathrm{~km}^{2}$ of this theme are required. Three blocks can contribute to representation of this theme: Hand Hills, Grassy Island Lake (i.e., Muddy Buttes), and Neutral Hills-Middle Lake (Table 34). It is unlikely that the targets for this theme can be met within these blocks.

Recommendation: Consider protecting all available sites that have representation of this theme.

- Protected slope: To meet the Level 1 NHT targets, about $9.4 \mathrm{~km}^{2}$ of this theme are required. Three blocks could contribute to representation of this theme: Hand Hills, Grassy Island Lake and Neutral Hills (Table 34). The targets for this theme can probably be met from within these three blocks.

Recommendation: Focus on all three blocks to ensure sufficient representation of this theme across its range of variation.

- Floor/Stream: To meet the Level 1 NHT targets, about $25 \mathrm{~km}^{2}$ of this theme are required. Three blocks could contribute to representation of this theme: Hand Hills, Kirkpatrick Native Prairie and Grassy Island Lake (Table 34). Due to the small amounts of this theme that occur in these blocks, it is unlikely that the targets can be met.

Recommendation: Consider protecting all available sites that have representation of this theme.

- Springs: To meet the Level 1 NHT targets, about $2.4 \mathrm{~km}^{2}$ of this theme are required. Three blocks could contribute to representation of this theme: Hand Hills, Grassy Island Lake and Neutral Hills (Table 34). Due to the small amounts of this theme that occur in these blocks, it is unlikely that the targets can be met.

Recommendation: Consider protecting all available sites that have representation of this theme.

- Wet meadow: Level 1 NHT targets for this theme have been met, however, they were achieved primarily from one protected area - Rumsey South Natural Area. Other blocks that could contribute to a wider representation of this theme across the subregion include: Hand Hills, Kirkpatrick Native Prairie, Grassy Island Lake, Bodo and Neutral Hills-Middle Lakes (Table 34). 
Recommendation: Focus on the Grassy Island Lake Block (transition area from mixedgrass to fescue) and the Bodo Block (transition area from fescue prairie to parkland) to ensure representation of this theme across its range of variation.

- Shallow marsh: Level 1 NHT targets for this theme have been met, however, they were achieved primarily from one protected area - Rumsey South Natural Area. Other blocks that could contribute to a wider representation of this theme include: Hand Hills, Grassy Island Lake, Bodo and Neutral Hills-Middle Lakes (Table 34).

Recommendation: Focus on the Bodo Block in the eastern part of the subregion and the Hand Hills Block in the southwestern part to ensure representation of this theme across its range of variation.

- Deep marsh: To meet the Level 1 NHT targets, about $0.7 \mathrm{~km}^{2}$ of this theme are required. None of the large blocks of land, except Rumsey South, have significant representation of this theme. It may be possible to meet this target by adding adjacent crown lands to the Rumsey South Natural Area that have representation of this theme (e.g., McKee Lake area). Other "areas of significance" have examples of this theme (e.g., Lanes Lake, Marion/Shooting Lakes) but they are located within areas that have little or no crown land.

Recommendation: Focus on adding adjacent crown lands with "deep marsh" themes to the existing Rumsey South Natural Area.

- Alkali wetland: To meet the Level 1 NHT targets, about $0.7 \mathrm{~km}^{2}$ of this theme are required. Five blocks could contribute to representation of this theme: Hand Hills, Kirkpatrick Native Prairie, Grassy Island Lake, Bodo and Neutral Hills-Middle Lakes (Table 34). The targets for this theme can probably be met from within these blocks.

Recommendation: Focus on the Hand Hills Block in the southwestern part of the subregion and the Grassy Island Lake Block in the eastern part to ensure representation of this theme across its range of variation.

- Lake: To meet the Level 1 NHT targets, about $10 \mathrm{~km}^{2}$ of this theme are required. Four blocks could contribute to representation of this theme: Hand Hills, Kirkpatrick Native Prairie, Grassy Island Lake and Neutral Hills-Middle Lakes (Table 34). The targets for this theme can probably be met from within these blocks.

Recommendation: Focus on the Hand Hills Block (e.g., Handhills Lake, Little Fish Lake) in the southwestern part of the subregion, Kirkpatrick Native Prairie (e.g., Kirkpatrick Lake) in the centre part and the Grassy Island Lake Block in the eastern part to ensure representation of this theme across its range of variation. 


\section{Chapter 2.7 Filling the Gaps in the Mixedgrass Subregion}

\section{Size and Land Ownership}

- The subregion covers about $19000 \mathrm{~km}^{2}$.

- The subregion is comprised of three separate parcels:

- the "Lethbridge Parcel" in the west, covering about $16188 \mathrm{~km}^{2}$

- the "Cypress Hills Parcel" in the east, covering about $2651 \mathrm{~km}^{2}$

- the "Sweetgrass Hills Parcel" in the south, covering about $337 \mathrm{~km}^{2}$

- The majority (about $74 \%$ or $14141 \mathrm{~km}^{2}$ ) of the subregion is privately owned (Table 35 ).

- The largest proportion (about 78\%) of privately owned land (i.e., freehold land) is found within the Lethbridge Parcel.

- About $22 \%\left(4250 \mathrm{~km}^{2}\right)$ of the lands in the subregion are crown; $14.2 \%\left(2726 \mathrm{~km}^{2}\right)$ provincially owned and $7.9 \%\left(1523 \mathrm{~km}^{2}\right)$ federally owned (Table 35$)$.

- Most of the crown land is in the Cypress Hills and Sweetgrass Hills Parcels.

- Of the provincial crown land in the subregion, about $88 \%\left(2413 \mathrm{~km}^{2}\right)$ consists of contiguous areas more than $10 \mathrm{~km}^{2}$ in size (GIS calculations).

- In total, about $4 \%\left(772 \mathrm{~km}^{2}\right)$ of the lands in the subregion are categorized as "mixed" (544 $\left.\mathrm{km}^{2}\right)$, "other" $\left(22 \mathrm{~km}^{2}\right)$ and "water" $\left(206 \mathrm{~km}^{2}\right)$, as shown in Table 35.

\begin{tabular}{|c|c|c|c|c|c|c|c|c|}
\hline \multirow[t]{2}{*}{ Category } & \multicolumn{2}{|c|}{$\begin{array}{l}\text { Lethbridge } \\
\text { Parcel }\end{array}$} & \multicolumn{2}{|c|}{$\begin{array}{c}\text { Cypress Hills } \\
\text { Parcel }\end{array}$} & \multicolumn{2}{|c|}{$\begin{array}{c}\text { Sweetgrass Hills } \\
\text { Parcel }\end{array}$} & \multicolumn{2}{|c|}{ Total } \\
\hline & $\left(\mathrm{km}^{2}\right)$ & $\%$ & $\left(\mathrm{~km}^{2}\right)$ & $\%$ & $\left(\mathrm{~km}^{2}\right)$ & $\%$ & $\left(\mathrm{~km}^{2}\right)$ & $\%$ \\
\hline Crown - provincial & 1363 & 8.3 & 1182 & 44.8 & 182 & 53.8 & 2727 & 14.2 \\
\hline Crown - federal* & 1523 & 9.3 & -- & --- & --- & --- & 1523 & 7.9 \\
\hline Freehold & 12555 & 77.6 & 1433 & 54.3 & 153 & 45.3 & 14141 & 73.8 \\
\hline Mixed & 520 & 3.2 & 21 & 0.8 & 3 & 0.8 & 544 & 2.8 \\
\hline Other & 23 & 0.1 & -- & --- & --- & --- & 23 & 0.1 \\
\hline Water** & 204 & 1.3 & 2 & 0.1 & --- & --- & 206 & 1.1 \\
\hline Total & 16188 & 99.8 & 2639 & 100 & 337 & 99.9 & 19164 & 99.9 \\
\hline \multicolumn{9}{|c|}{$\begin{array}{l}\text { NOTE: The size of the subregion reported in Report } 3 \text { (Alberta Environmental Protection } 1994 \mathrm{~b} \text { ) is } 19176.65 \\
\mathrm{~km}^{2} \text {. The discrepancy of } 12.8 \mathrm{~km}^{2} \text { is due to a difference in the level of precision between the land ownership and } \\
\text { natural region GIS coverages. Land ownership figures were generated from LSAS quarter-section data, adjusted } \\
\text { using } 1: 250,000 \text { lake coverage. } \\
{ }^{*} \text { Federal crown lands include three Indian Reserves (Peigan, Blood, Siksika). } \\
{ }^{* *} \text { a GIS calculation for all waterbodies with an area of } 1.5 \mathrm{~km}^{2} \text { or larger. }\end{array}$} \\
\hline
\end{tabular}




\section{General Comments}

- Majority of the subregion is highly disturbed and fragmented, and includes.

- Lethbridge as the largest city.

- many towns and villages (e.g., Fort Macleod, Magrath, Raymond, Picture Butte, Claresholm, Vulcan, Gleichen).

- farming, ranching and irrigation as major land uses.

- Traversed by several highways (e.g., Highway 1, 2, 3, 4, 5, 23 and 56).

- Has the second lowest road density of the four grassland subregions, at $0.58 \mathrm{~km} / \mathrm{km}^{2}$ (Table 5).

- Has the second lowest wellsite density of the four grassland subregions, at 0.37 wellsites $/ \mathrm{km}^{2}$ (Table 9).

- About $20 \%\left(3792 \mathrm{~km}^{2}\right)$ of the subregion has more than $76 \%$ of its native prairie remaining (Table 36). The majority of native prairie in this category occurs within the Cypress Hills and Sweetgrass Hills Parcels, particularly in the Twin River, Eagle Butte, Cypress Hills south and Black Butte areas. Other significant blocks of native prairie in this category occur in the Majorville and Travers-Little Bow areas.

- About $4 \%\left(810 \mathrm{~km}^{2}\right)$ of the subregion has between 51 and $75 \%$ of its native prairie remaining (Table 36). Significant blocks of native prairie in this category remain in the following areas: southeast of Little Fish Lake, Majorville and Willow Creek-Mud Lake (Map D, back pocket).

- At least $68 \%\left(13023 \mathrm{~km}^{2}\right)$ of the subregion is less than half native prairie, and of that, at least $40 \%\left(7732 \mathrm{~km}^{2}\right)$ has no prairie remaining (Table 36$)$.

- The Lethbridge Parcel has experienced the greatest impact of the three parcels - about $58 \%$ has no native prairie (Table 36).

\section{Protected Areas and ESAs}

- Includes no protected areas larger than $10 \mathrm{~km}^{2}$. The largest protected area is Red Rock Coulee Natural Area $\left(3.24 \mathrm{~km}^{2}\right)$.

- A total of 44 ESAs occurs wholly or partially within the subregion (Map C). These include:

- 8 internationally significant ESAs: Kipp Section, Lenzie Section, Oldman River-Macleod, Oldman River-Brocket, Oldman Section, Scabby Butte, St. Mary Type Section, Writing-On-Stone.

- 12 nationally significant ESAs: Black Butte, Cypress Hills, Lower Belly River, Lower Sweetgrass Hills, Manyberries Creek Badlands, McGregor Lake, Milk River Canyon, Milk River Ridge-Unglaciated, Ross Creek, Sage Creek, Travers Reservoir, Turin Dunes

- 24 provincially significant ESAs: Bluestem, Bow River, Bow River-Majorville, Deer Creek, Eagle Butte, Keho Lake, Little Bow Reservoir, Lower St. Mary River, Majorville, McAlpine Creek, Milk River-Breed Creek, Milk River-Pakowki/Pinhorn, Milk River Ridge-North East, Milk River Ridge-Northeast Slope, Milk River Ridge Reservoir, Oldman River-Lethbridge East, Porcupine Hills, Red Deer River-Finnegan/Steveville Terraces, Red Rock Coulee, Stirling Lake, Twin River Ash, Twin River Valley, Tyrell-Rush Lakes, Wintering Hills. 


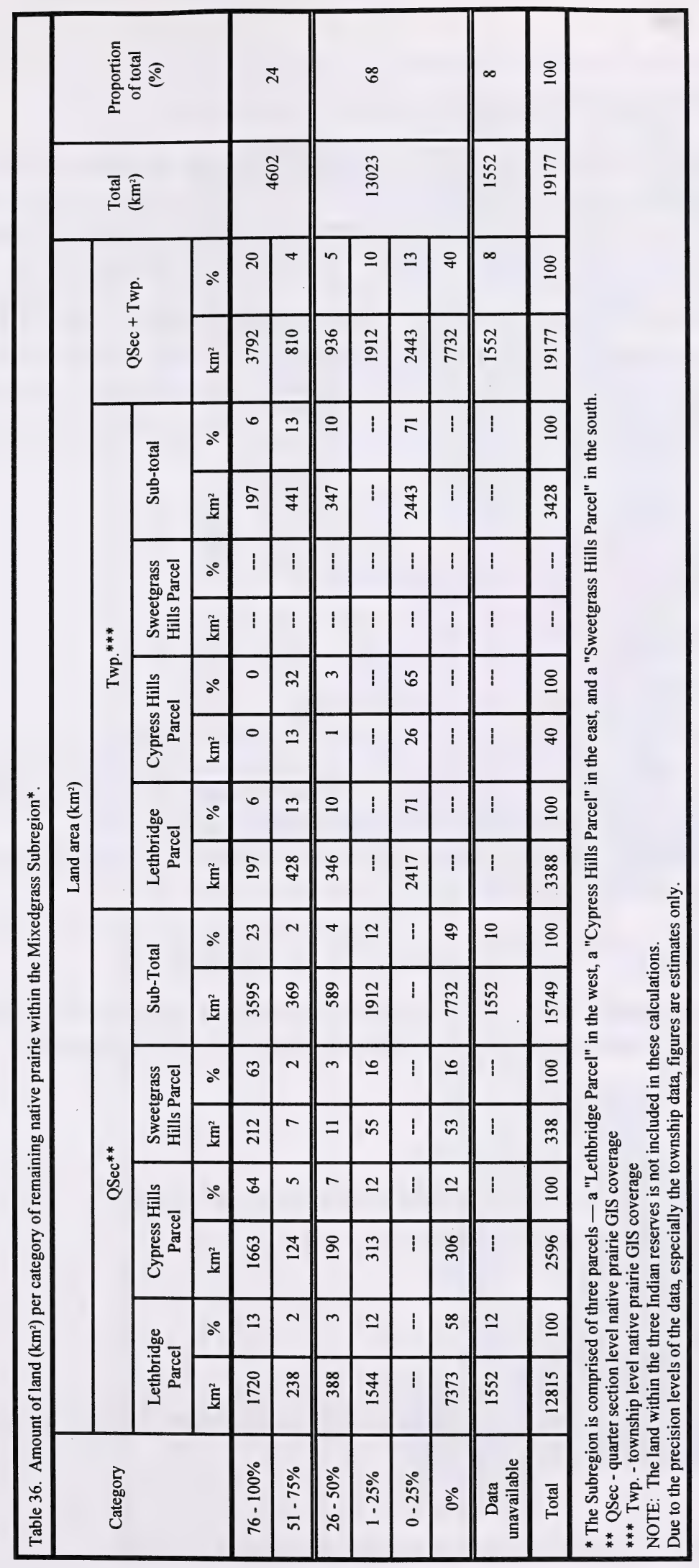




\section{Targets and Prospects for Protection}

The target for protection of Level 1 Natural History Themes is adequate representation of 13 Natural History Themes, which total a minimum $262.5 \mathrm{~km}^{2}$, or $1.37 \%$ of the subregion (Table 23). To date, no protected areas greater than $10 \mathrm{~km}^{2}$ have been established within the subregion and, therefore, none of the targets have been achieved. This subregion has been heavily disturbed, particularly within the Lethbridge Parcel and the northern portion of the Cypress Hills Parcel. It may therefore be difficult to achieve adequate representation of all Level 1 NHTs across their range of variation. However, there are still quality areas within the subregion that would help to meet some identified targets. Some of the areas having the greatest potential are blocks of intact prairie greater than $10 \mathrm{~km}^{2}$ in size. Prospective protected areas are discussed in detail for the Lethbridge, Cypress Hills and Sweetgrass Hills Parcel. Their locations are shown on Map 10.

\section{Lethbridge Parcel}

\section{L1. Dorothy East Block (NE of Red Deer River)}

- Much of the area has $51-75 \%$ remaining in native prairie.

- Blocks of contiguous crown land greater than $10 \mathrm{~km}^{2}$ occur within this area.

- Adjoins with the blocks that include Hand Hills Ecological Reserve and Little Fish Lake Provincial Park (see discussion of the Hand Hills Block in Chapter 2.6). Both Hand Hills and Little Fish Lake have been identified as internationally significant ESAs.

- Although not identified as an ESA, this block may include similar biophysical features as those identified for the Hand Hills Block.

\section{Potential for contributing to Level 1 Natural History Theme representation:}

This area has not been evaluated, but its crown lands have potential to contribute to the following Level 1 NHTs: ground moraine, exposed slope, protected slope, springs, wet meadow.

\section{L2. Majorville Block}

- More than half of the area has greater than $75 \%$ remaining in native prairie.

- Contains areas with a variety of grazing regimes.

- Includes an aboriginal "medicine wheel."

- Includes the following ESA:

Majorville (provincially significant)

- About $95 \%$ within the subregion.

- Contains one site under land use reservation as a proposed Natural Area - Lomond (Protective Notation). 
Mixedgrass Natural Sub-region

Grassland Natural Sub-regions

$\square$ Mixedgrass

Blocks For Evaluation

Transportation Network

Primary - Paved

N Primary - Divided

Secondary - Paved

Secondary = Gravel

\section{Protected Areas}

Ecological Reserves (OC)

Natural Areas (OC)

Provincial Parks

Wildlife Sanctuaries

\section{Land Ownership}

Crown - Provincial

Crown - Federal (Military Reserve)

Crown - Federal (Indian Reserve)

\section{Mixed}

Lakes (> $1.5 \mathrm{sq} . \mathrm{km})$

Townships

Cities

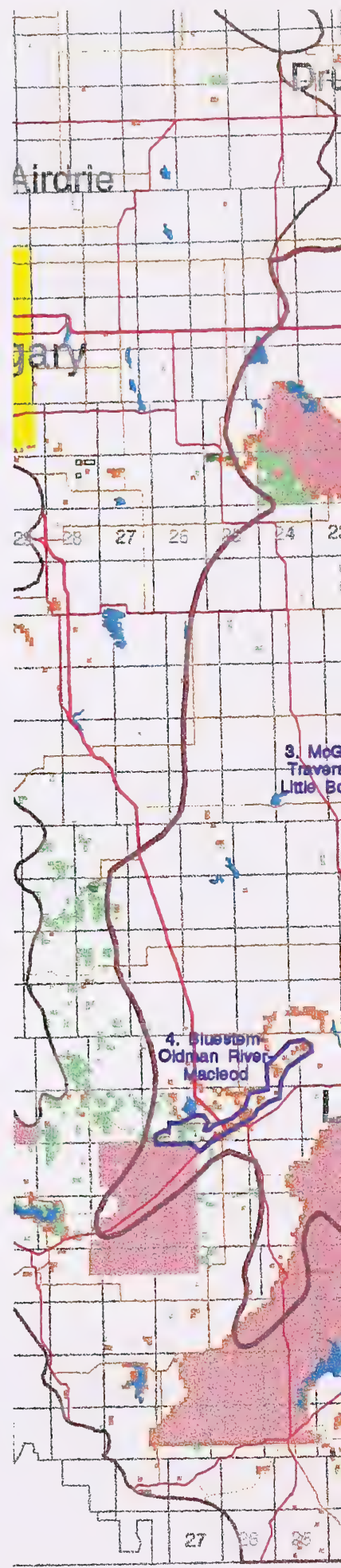




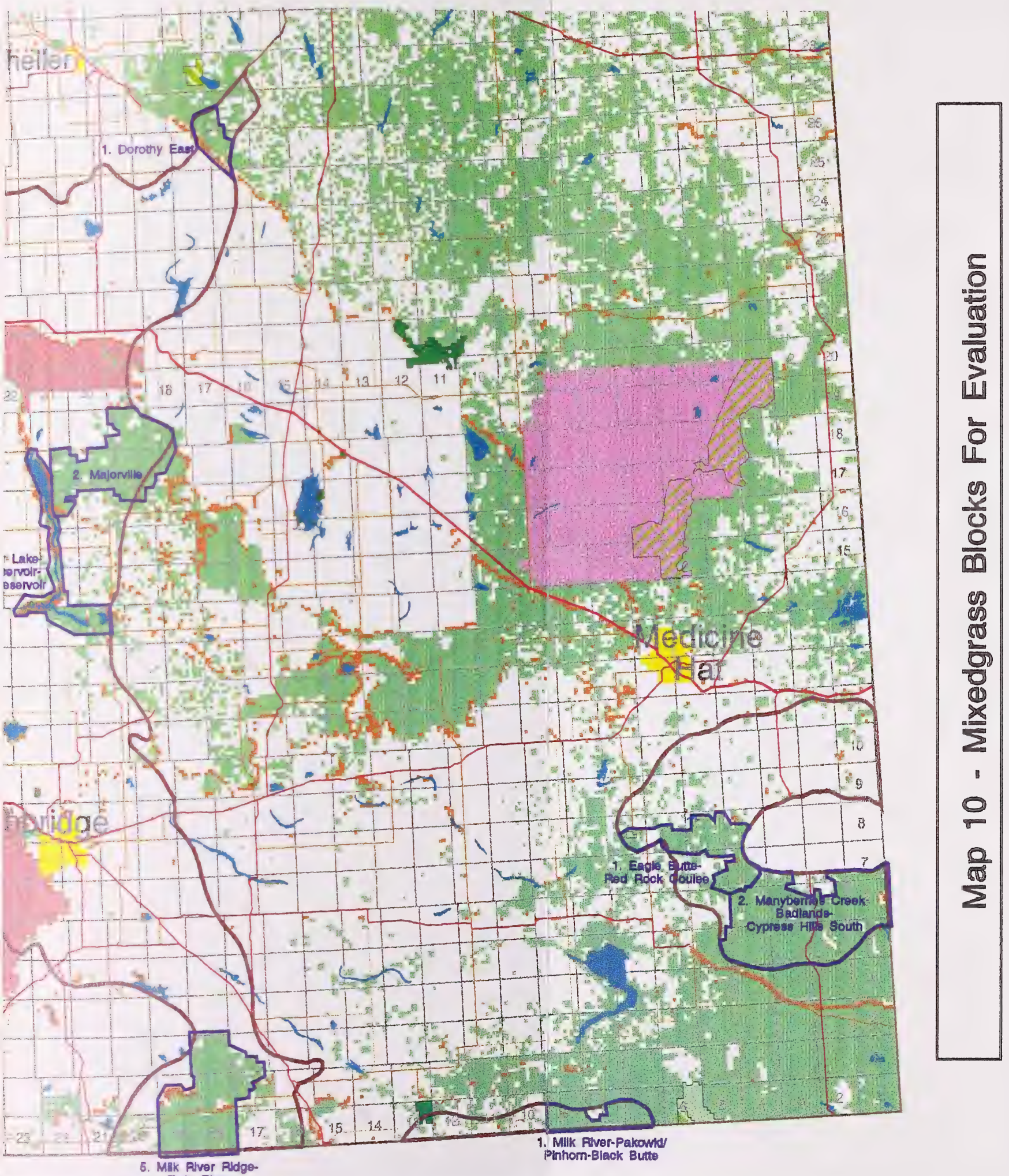


- Biophysical features include:

- well-managed native mixed grassland on hummocky moraine

- several pairs of nesting Burrowing Owls (RED-listed by AEP 1996; endangered rating by COSEWIC)

- feeding and nesting area for sensitive birds of prey species including Golden Eagle (YeLLOw B-listed by AEP 1996), Prairie Falcon (YeLlOw A-listed by AEP 1996) and Ferruginous Hawk (BLUE-listed by AEP 1996; vulnerable rating by COSEWIC)

- important for wintering and migrating birds of prey, including Snowy Owls and Rough-legged Hawks

- numerous wetlands, with some waterfowl production, especially in southwestern portions in wetter years. Waterfowl production and staging ponds are found in Section 36-T17-R21 and Section 3-T18-R21

- moderate numbers of nesting Wilson's Phalaropes

- shallow valley of the Bow River with some coulees, exposed badlands and cliff faces

- major waterfowl staging area in spring and fall, especially for puddle ducks

- staging area for several shorebirds

- feeding area along the Bow River for American White Pelicans (YeLlow B-listed by AEP 1996)

- Blocks of contiguous crown land greater than $10 \mathrm{~km}^{2}$ occur within and adjacent to the identified ESA in this area.

Potential for contributing to Level 1 Natural History Theme representation:

Crown lands within this block have excellent potential for contributing to the following Level 1 NHTs, all of which are under-represented.

- Majorville ESA: glacial lake bed, ground moraine, hummocky moraine, sandy plain, exposed slope, wet meadow, shallow marsh.

\section{L3. McGregor Lake-Travers Reservoir-Little Bow Reservoir Block}

- Much of the area is more than $75 \%$ native prairie.

- Includes the following ESAs:

(a) McGregor Lake (nationally significant)

- ESA is entirely within the subregion.

- McGregor Lake occupies most of the crown land within the ESA.

- Biophysical features include:

- large reservoir with little marsh development

- major waterfowl staging and production area

- American White Pelicans (YeLlow B-listed by AEP 1996) feed on the reservoir

- native mixed grassland next to the reservoir

- habitat for shorebird production and migration, especially at the north end of the reservoir 
(b) Travers Reservoir (nationally significant)

- ESA is entirely within the subregion.

- Most of the crown land within the ESA underlies the reservoir.

- Biophysical features include:

- native mixed grasslands, badlands and eroding coulees next to the reservoir

- part of the Little Bow River valley

- major waterfowl staging and production area

- American White Pelicans (YELLOw B-listed by AEP 1996) feed on this reservoir

- key White-tailed Deer habitat along the Little Bow River valley

- extensive nesting area for birds of prey including Golden Eagle (YELLOW B-listed by AEP 1996), Ferruginous Hawk (BLUE-listed by AEP 1996; vulnerable rating by COSEWIC) and Prairie Falcon (YELLOw A-listed by AEP 1996) - highest density in western portion

- historic nesting area of Peregrine Falcon (RED-listed by AEP 1996; endangered rating by COSEWIC) along the north shore of the western arm

- populations of low milk vetch (Astragalus lotiflorus, S2) in the northwest quarter of section 19-T14-R20-W4M

(c) Little Bow Reservoir (provincially significant)

- ESA is about $98 \%$ within the subregion.

- Reservoir occupies most of the crown land within the ESA.

- Biophysical features include:

- reservoir with several islands

- waterfowl staging and production area, for diving ducks, grebes and puddle ducks

- Double-crested Cormorant colony (YELLOW B-listed by AEP 1996)

- feeding area for American White Pelicans (YELLow B-listed by AEP 1996)

- some shorebird and marsh bird production

- native mixed grassland next to reservoir

- nesting Burrowing Owls (RED-listed by AEP 1996; endangered rating by COSEWIC)

- Sizeable blocks of contiguous crown land greater than $10 \mathrm{~km}^{2}$ occur within the Travers and Little Bow Reservoir ESAs.

Potential for contributing to Level 1 Natural History Theme representation:

Crown lands within this block have excellent potential for contributing to the following NHTs, all of which are under-represented:

- McGregor Lake ESA: glacial lake bed, hummocky moraine, sandy plain, exposed slope.

- Travers Reservoir ESA: hummocky moraine, sandy plain, dune field, exposed slope.

- Little Bow Reservoir ESA: hummocky moraine, wet meadow. 


\section{L4. Bluestem-Oldman River-Macleod Block}

- Portions of the Block have between $50-75 \%$ remaining in native prairie.

- Crown land is scattered along the Oldman River and west of Fort Macleod.

- Has some lightly grazed areas.

- Includes the following ESAs:

(a) Oldman River-Macleod (internationally significant)

- ESA is entirely within the subregion.

- Contains two sites under land use reservation as proposed Natural Areas - Fort Macleod (Protective Notation) and Willow Creek (Protective Notation).

- Biophysical features include:

- part of Canada's most extensive narrow-leaved and balsam poplar riparian woodland,

- shrubbery and moist channel habitats

- productive and diverse breeding bird habitats, including habitat for Black-headed Grosbeak

- eroding slopes with priority plant species, including rush-pink (Stephanomeria runcinata, $\mathrm{S} 2$ )

- floodplains with priority plant species, including water speedwell (Veronica catenata, S2)

- key Mule Deer and White-tailed Deer habitat

- nesting habitat for Ferruginous Hawks (BLUE-listed by AEP 1996; vulnerable rating by COSEWIC), Prairie Falcons (YELLOw A-listed by AEP 1996) and Golden Eagles (YELLOW B-listed by AEP 1996)

- colony of Great Blue Herons (YELLow B-listed by AEP 1996)

- American White Pelican (YELLow B-listed by AEP 1996) feeding area

- important Pleistocene and Cretaceous geological sections

\section{(b) Bluestem (provincially significant)}

- About half of the ESA is within the subregion.

- Includes small patches of cultivation.

- Biophysical features include:

- coarse glacial lake, outwash and till deposits

- meltwater delta complex along the Oldman River

- diversity of mixed grassland and foothills grassland types

- silverberry and thorny buffaloberry shrubbery

- grasslands of fescue and wheat grass that are interspersed with drainages and small alkali ponds

- widespread patches of little bluestem (Schizachyrium scoparium, S2) grassland vegetation; some in excellent condition

- particularly good examples of little bluestem are found in Sections 3 and 33 of T9-R27-W4M

- abundant ground squirrel populations - a food source and feeding area for birds of prey including Prairie Falcon (YELLOw A-listed by AEP 1996), Golden Eagle (YELLOW B-listed by AEP 1996) and Ferruginous Hawk (BLUE-listed by AEP 1996; vulnerable rating by COSEWIC) 
- deer habitat in shrubby areas closer to the Oldman River

- glacial erratics of the Foothills Erratics Train

- Potential for contributing to Level 1 Natural History Theme representation:

The only sizeable block of contiguous crown land is located in T9-R27-W4M. It is nearly 10 $\mathrm{km}^{2}$ in size and may, therefore, contribute to the representation of Level 1 NHTs. The crown land along the river in the Oldman River-Macleod ESA may also have some potential to contribute to the representation of Level 1 NHTs.

- Oldman River-Macleod ESA: sandy plain, exposed slope, floor/stream.

- Bluestem ESA: ground moraine, sandy plain, springs, alkali wetland.

\section{L5. Milk River Ridge-Twin River Block}

- Most of the area is more than $75 \%$ native prairie.

- Large blocks of contiguous crown land greater than $10 \mathrm{~km}^{2}$ occur within this area.

- Adjacent to the United States border.

- Includes the following ESAs:

(a) Milk River Ridge-Northeast Slope (provincially significant)

- ESA is about $65 \%$ within the subregion.

- Biophysical features include:

- deeply incised ravines with intervening ridges

- diverse ravine shrubbery and grassland

- several disjunct plants; moderate potential for rare plants

- diversity of breeding birds

- key White-tailed Deer habitat

(b) Milk River Ridge-Northeast (provincially significant)

- ESA is about $50 \%$ within the subregion.

- Part of extensive foothills grassland.

- Biophysical features include:

- foothills grasslands

- wetlands with some waterfowl production, especially in wetter years

- key habitat for Pronghorn (YeLLOw B-listed by AEP 1996) in southern portion

(c) Twin River-Ash (provincially significant)

- ESA is entirely within the subregion.

- Biophysical features include:

- valleys of the North and South Milk Rivers

- incised portions of the river valleys have dense populations of nesting birds of prey including Ferruginous Hawk (BLUE-listed by AEP 1996; vulnerable rating by COSEWIC), Golden Eagle (YELLOw в-listed by AEP 1996) and Prairie Falcon (YELLOW A-listed by AEP 1996) 
- upland grasslands provide hunting area for birds of prey

- key habitat for Pronghorn (YELLOw B-listed by AEP 1996) in northern portion

- habitat for Yellow-bellied Marmot

- one metre thick deposits of Mazama ash (Twin River Ash)

- priority plant species including prickly milk vetch (Astragalus kentrophyta, S1S2) and tufted hymenopappus (Hymenopappus filifolius, S1S2)

- St. Mary River Shorthead Sculpin (rare fish, S1T-ranked by ANHIC)

- erratics of the McNeill Erratics Train

- small areas of diverse shrubbery and badlands along the North Milk River

\section{(d) Twin River Valley (provincially significant)}

- ESA is entirely within the subregion.

- A transitional area from mixedgrass to foothills grassland.

- Biophysical features include:

- valleys of the North and South Milk Rivers

- incised portions of river valleys have dense populations of nesting birds of prey including Ferruginous Hawk (BLUE-listed by AEP 1996; vulnerable rating by COSEWIC), Golden Eagle (YELLow в-listed by AEP 1996) and Prairie Falcon (YELLOW A-listed by AEP 1996)

- upland grasslands provide hunting area for birds of prey

- key habitat for Pronghorn (YeLLOw B-listed by AEP 1996)

- habitat for Yellow-bellied Marmot

- priority plant species, including tufted hymenopappus (Hymenopappus filifolius, S1S2) and whitlow-grass (Draba reptans, S2)

- rare fish, including: St. Mary River Shorthead Sculpin (S1T-ranked by ANHIC) and Stonecat (S1)

- unusual artesian source wetland with sandy shore in Section 30-T2-R18-W4M

\section{Potential for contributing to Level 1 Natural History Theme representation:}

Crown lands within this block have excellent potential for contributing to the following NHTs, all of which are under-represented.

- Milk River Ridge-Northeast Slope ESA: ground moraine, hummocky moraine, exposed slope, protected slope, springs.

- Milk River Ridge-Northeast ESA: ground moraine, hummocky moraine, sandy plain, exposed slope, protected slope, floor/stream, wet meadow, shallow marsh, deep marsh.

- Twin River-Ash ESA: exposed slope.

- Twin River Valley ESA: ground moraine, hummocky moraine, sandy plain, exposed slope, floor/stream, wet meadow.

\section{Other Areas of Significance within the Lethbridge Parcel}

These area areas that are generally not large enough to contribute to the representation of Level 1 NHTs, yet have been recognized for their biophysical significance. 


\section{A. Keho Lake}

- A provincially significant ESA.

- Area is entirely within the subregion.

- Small amounts of crown land occur around the lake.

- Biophysical features include:

- large reservoir with some marsh areas

- waterfowl staging and production area, including diving ducks

- Double-crested Cormorant (YELLOw B-listed by AEP 1996) colony has been recorded in past years.

\section{Consideration:}

- Maintain all remaining provincial crown land within this ESA in a natural state.

\section{B. Turin Dunes}

- A nationally significant ESA.

- Approximately $50 \%$ of the ESA is within the subregion.

- About 260 ha of crown land occur in the area.

- Biophysical features include:

- native mixed grassland on sand dune terrain with active blowouts

- several priority plant species, including: clammyweed (Polanisia dodecandra, S1)), low milk vetch, (Astragalus lotiflorus, S2), low annual lupine (Lupinus pusillus, S3) and smooth narrow-leaved goosefoot (Chenopodium subglabrum, S2)

- breeding habitat for Grasshopper Sparrow (YELLOw B-listed by AEP 1996)

\section{Considerations:}

- Maintain all remaining provincial crown land within this ESA in a natural state.

- Assess further those provincial crown lands containing special features (e.g., habitats for priority plant species, breeding habitats for Grasshopper Sparrow) for consideration as an established protected area.

\section{Oldman River-Lethbridge East}

- A provincially significant ESA.

- About $80 \%$ of this ESA is within the subregion.

- Although scattered areas of crown land occur along the river, the amount is too small and discontinuous to contribute to the representation of Level 1 NHTs.

- Some cultivation of river terraces.

- Biophysical features include:

- deeply cut river valley eroding cutbanks and rock outcrops

- extensive slump blocks 
- nesting area for sensitive birds of prey including Prairie Falcon (YeLLOw A-listed by AEP 1996) and Golden Eagle (YELLow B-listed by AEP 1996)

- feeding area for American White Pelican (YELLOw B-listed by AEP 1996)

- habitat for Lark Sparrow (YELLOw B-listed by AEP 1996)

\section{Consideration :}

- Maintain all remaining provincial crown land within this ESA in a natural state.

\section{Kipp Section}

- An internationally significant ESA.

- The entire ESA is within the subregion.

- Little crown land occurs in this ESA.

- Biophysical features include:

- eroded cutbank of the Oldman River has exposed one of the best sequences of Quaternary deposits in Canada, including preglacial, glacial, interglacial and post-glacial sediments

- Kipp "megablock" is also found here. This is a large bedrock section (up to $4 \mathrm{~km}$ long) that was rafted during glaciation and deposited on top of glacial till. It is now exposed in the cutbank.

\section{Considerations:}

- Maintain all remaining provincial crown land within this ESA in a natural state.

- Assess further those provincial crown lands containing the geological special features for consideration as an established protected area.

\section{E. Lower Belly River}

- A nationally significant ESA.

- About $95 \%$ of this ESA is within the subregion.

- Although small areas of crown land are scattered along the river, the amount is too small and discontinuous it to contribute to the representation of Level 1 NHTs.

- Biophysical features include:

- some of the most extensive narrow-leaved cottonwood riparian woodland and shrubbery in Canada

- the largest and most lightly grazed areas are in Section 27-T6-R25-W4M; Section 32T5-R25-W4M; and Section 5, 8 and 9-T5-R26-W4M

- diverse breeding bird populations

- Great Blue Heron (YeLLow B-listed by AEP 1996) colony in Section 27-T6-R25-W4M

- key White-tailed Deer habitat near the junction with the Waterton River. 


\section{Considerations:}

- Maintain all remaining provincial crown land within this ESA in a natural state.

- Assess further those provincial crown lands containing special features (e.g., Great Blue Heron colony, important bird nesting habitats, riparian stands) as possible protected areas.

\section{F. Lower St. Mary River}

- A provincially significant ESA.

- Approximately $60 \%$ of the ESA is within the subregion.

- Little crown land occurs in this ESA.

- Biophysical features include:

- grassy and rocky valley of the St. Mary River

- massive rock outcrops with abundant ammonite fossils

- saline oxbow lake and reverse geological fault at junction of St. Mary River and Pothole Creek

\section{Considerations:}

- Maintain all remaining provincial crown land within this ESA in a natural state.

\section{G. Stirling Lake}

- A provincially significant ESA.

- The entire ESA is within the subregion.

- Little crown land occurs in this ESA.

- A Ducks Unlimited wetland project.

- Biophysical features include:

- large, slightly alkaline wetland

- waterfowl staging and production area

- nesting colony of Black-crowned Night Herons (YELLOw B-listed by AEP 1996)

- productive for variety of smaller marsh birds

- nesting record of Black-necked Stilt (YELLOw B-listed by AEP 1996)

\section{Considerations:}

- Maintain all remaining provincial crown land within this ESA in a natural state.

\section{H. Tyrell - Rush Lakes}

- A provincially significant ESA.

- Approximately $95 \%$ of the ESA is within the subregion.

- Little crown land occurs in this ESA. 
- A Ducks Unlimited wetland project.

- Biophysical features include:

- alkaline lakes and marshes

- major waterfowl production and staging area

- some adjacent native grassland

\section{Considerations:}

- Maintain all remaining provincial crown land within this ESA in a natural state.

\section{Milk River Ridge Reservoir}

- A provincially significant ESA.

- Approximately $98 \%$ of the ESA is within the subregion.

- Little crown land occurs in this ESA.

- Biophysical features include:

- a large reservoir north of the Milk River Ridge

- colonies of gulls and Double-crested Cormorants (YELLOw B-listed by AEP 1996)

- waterfowl staging and production area

- feeding area for American White Pelicans (YeLLow в-listed by AEP 1996)

\section{Considerations:}

- Maintain all remaining provincial crown land within this ESA in a natural state.

\section{Cypress Hills Parcel}

\section{C1. Eagle Butte-Red Rock Coulee Block}

- Much of the area has more than native prairie $75 \%$ remaining.

- Includes the following ESAs:

(a) Eagle Butte (provincially significant)

- ESA is entirely within the subregion.

- Biophysical features include:

- lush foothills, fescue grassland, wetlands and riparian shrubbery

- diversity of breeding birds

- key deer habitat.

(b) Red Rock Coulee (provincially significant)

- ESA is about $60 \%$ within the subregion.

- Includes Red Rock Coulee Natural Area. 
- Biophysical features include:

- badlands, mixed grassland and spring-fed wooded coulee

- spectacular sandstone concretions eroded out of surrounding softer bedrock

- hibernacula of Prairie Rattlesnake (BLUE-listed by AEP 1996)

- Both ESAs contain sizeable blocks of contiguous crown land greater than $10 \mathrm{~km}^{2}$.

\section{Potential for contributing to Level 1 Natural History Theme representation:}

Crown lands within this block have excellent potential for contributing to the following Level 1 NHTS, all of which are under-represented.

- Eagle Butte ESA: ground moraine, hummocky moraine, exposed slope, protected slope, floor/stream, wet meadow, shallow marsh, deep marsh, alkali wetland.

- Red Rock Coulee ESA: ground moraine, hummocky moraine, exposed slope, protected slope, springs, wet meadow.

\section{C2. Manyberries Creek Badlands-Cypress Hills South Block}

- Most of the area has more than $75 \%$ remaining native prairie.

- Includes the following ESAs:

(a) Manyberries Creek Badlands (nationally significant)

- ESA is about $90 \%$ within the subregion.

- Biophysical features include:

- extensive area of grassland

- badlands with intriguing juniper patterning on sandier soils

- riparian creek habitats at the base of the Manyberries badlands

- extensive riparian tall shrubbery along southeastern drainages

- saline springs with diverse butterfly populations

- priority plant species, including: one-spike oat-grass (Danthonia unispicata, S2), Watson's knotweed (Polygonum watsonii, S2) and rush pink (Stephanomeria runcinata, S2)

- habitat for Short-horned Lizard (BLUE-listed by AEP 1996; vulnerable rating by COSEWIC)

- dancing grounds of Sage Grouse (BLUE-listed by AEP 1996) and Sharp-tailed Grouse (YELLOw A-listed by AEP 1996)

- nesting area for Ferruginous Hawks (BLUE-listed by AEP 1996; vulnerable rating by COSEWIC) and Burrowing Owls (RED-listed by AEP 1996; endangered rating by COSEWIC) 
(b) Cypress Hills (nationally significant)

- ESA is entirely within the subregion.

- Contains "special themes."

- Biophysical features include:

- unglaciated plateau of the Cypress Hills, surrounding woodlands and fescue grasslands

- fresh water springs and perched wetlands

- diversity of breeding birds

- disjunct vascular and non-vascular plants and birds

- priority plant species, including: low yellow evening-primrose (Oenothera flava, S2?), water speedwell (Veronica catenata, S2), yellow monkey-flower (Mimulus guttatus, SU), Watson's knotweed (Polygonum watsonii, S2), Alaska onion-grass (Melica subulata, S2), slender naiad (Najas flexilis, S2), halimolobos (Halimolobos virgata, S1), dwarf fleabane (Erigeron radicatus, S2), biscuitroot (Lomatium cous, S1), awnless trisetum (Trisetum wolfii, S1), striped form of the round-leaved orchid (Orchis rotundifolia var. lineata, $\mathrm{SU}$ ) and flowering quill-wort (Lilaea scilloides, S1).

- key moose, elk and deer habitat

- hibernacula for Red-sided Garter Snake (YeLLow A-listed by AEP 1996) and other snakes

- priority species, including: Northern Leopard Frog (RED-listed by AEP 1996), Broad-winged Hawk (Yellow B-listed by AEP 1996), Turkey Vulture (YELlow Blisted by AEP 1996), Baird's Sparrow (YELLow A-listed by AEP 1996) and Trumpeter Swan (BLUE-listed by AEP 1996)

- habitat for Ring-necked Duck, Lazuli Bunting and Common Poor-will

- dancing grounds of Sharp-tailed Grouse (YELLOw A-listed by AEP 1996)

- marsh bird and waterfowl production, including grebes and diving and dabbling ducks

- Sizeable blocks of contiguous crown land greater than $10 \mathrm{~km}^{2}$ occur within these ESAs.

- Blocks of crown land also occur to the south of Cypress Hills outside the ESAs.

\section{Potential for contributing to Level 1 Natural History Theme representation:}

Crown lands within these blocks have excellent potential for contributing to the following NHTS, all of which are under-represented.

- Manyberries Creek Badlands ESA: ground moraine, hummocky moraine, exposed slope, floor/stream, springs, wet meadow.

- Cypress Hills ESA: ground moraine, hummocky moraine, sandy plain, floor/stream, springs, wet meadow, shallow marsh, deep marsh. 


\section{Sweetgrass Hills Parcel}

\section{S1. Milk River-Pakowki/Pinhorn-Black Butte Block}

- Most of this block has more than $75 \%$ remaining in native prairie.

- Includes the following ESAs:

(a) Milk River-Pakowki/Pinhorn (provincially significant)

- ESA is about $20 \%$ within the subregion.

- Biophysical features include:

- extensive mixed grassland with rugged, diverse coulees

- diversity of breeding birds

- key habitat for Pronghorn (YELLow B-listed by AEP 1996), Mule and White-tailed Deer

- priority plant species, including: prickly milk-vetch (Astragalus kentrophyta, S1S2) and tufted hymenopappus (Hymenopappus filifolius, S1S2)

- nesting habitat for birds of prey including Prairie Falcon (YELLOW A-listed by AEP 1996) and Golden Eagle (YELLow B-listed by AEP 1996)

- priority animal species, including: Western Hognose Snake (BLUE-listed by AEP 1996), Ferruginous Hawk (BLUE-listed by AEP 1996; vulnerable rating by COSEWIC), Baird's Sparrow (YELLOW A-listed by AEP 1996) and Northern Leopard Frog (RED-listed by AEP 1996)

- alkaline springs

- excellent bedrock exposures along coulees

(b) Black Butte (nationally significant)

- ESA is entirely within the subregion.

- Biophysical features include:

- one of a series of dikes along the Milk River that radiate out from the Sweetgrass Hills

- priority plant species, including: linanthus (Linanthus septentrionalis, S2) and upland evening-primrose (Oenothera andina, S1)

- habitat for Yellow-bellied Marmot

- hibernacula for Prairie Rattlesnake (BLUE-listed by AEP 1996)

- Sizeable blocks of contiguous crown land greater than $10 \mathrm{~km}^{2}$ occur within these ESAs.

\section{Potential for contributing to Level 1 Natural History Theme representation:}

Crown lands within this block have excellent potential for contributing to the following NHTS, all of which are under-represented:

- Milk River-Pakowki/Pinhorn ESA: ground moraine, hummocky moraine, exposed slope, protected slope, floor/stream, springs, wet meadow, shallow marsh, alkali wetland.

- Black Butte ESA: entire butte is considered a special theme. 


\section{Meeting Level 1 Natural History Theme Targets}

Recommendations for meeting each of the Level 1 NHT targets are presented below. Although each theme is presented separately, potential protected areas may encompass more than one Level 1 NHT. To ensure maintenance of ecological integrity, representative protected areas ideally need to be greater than $10 \mathrm{~km}^{2}$ (where possible) and include representation of the themes across their range of variation. To ensure adequate representation of the region's biodiversity, several sites across the region need to be considered. Expanding current protected areas will ensure ecological integrity and is an effective way of meeting goals.

- Glacial lake bed: To meet the Level 1 NHT targets, $25 \mathrm{~km}^{2}$ of this theme are required. Two blocks could contribute to representation of this theme: Majorville and McGregor LakeTravers Reservoir-Little Bow Reservoir (Table 37). There is insufficient land within these blocks that contain this theme and, therefore, it is unlikely that the targets can be met (ANHIC 1997).

Recommendation: Consider protecting all available sites with representation of this theme.

- Ground moraine: To meet the Level 1 NHT targets, about $50 \mathrm{~km}^{2}$ of this theme are required. Several blocks could contribute to representation of this theme: Dorothy East, Majorville, Milk River Ridge-Twin River and Milk River-Pakowki/Pinhorn-Black Butte (Table 37). The targets for this theme can probably be met from within these blocks.

Recommendation: Focus on the Majorville Block, the Milk River Ridge-Twin River Block and the Milk River-Pakowki/Pinhorn-Black Butte Block to ensure representation of this theme across its range of variation.

- Hummocky moraine: To meet the Level 1 NHT targets, about $50 \mathrm{~km}^{2}$ of this theme are required. Several blocks could contribute to representation of this theme: Majorville, Milk River Ridge-Twin River, Eagle Butte-Red Rock Coulee, Manyberries Creek BadlandsCypress Hills South and Milk River-Pakowki/Pinhorn-Black Butte (Table 37). The targets for this theme can probably be met from within these blocks.

Recommendation: Focus on the Majorville Block, the Milk River Ridge-Twin River Block and the Eagle Butte-Red Rock Coulee Block to ensure representation of this theme across its range of variation.

- Sandy plain: To meet the Level 1 NHT targets, about $25 \mathrm{~km}^{2}$ of this theme are required. Several blocks could contribute to representation of this theme: Majorville, McGregor LakeTravers Reservoir-Little Bow Reservoir, Milk River Ridge-Twin River and Manyberries Creek Badlands-Cypress Hills South (Table 37). The targets for this theme can probably be met from within these blocks.

Recommendation: Focus on the McGregor Lake-Travers Reservoir-Little Bow Reservoir Block and the Milk River Ridge-Twin River Block in the Lethbridge Parcel and on the Manyberries Creek Badlands-Cypress Hills South Block in the Cypress Hills Parcel to ensure representation of this theme across its range of variation. 
- Dune field: To meet the Level 1 NHT targets, about $25 \mathrm{~km}^{2}$ of this theme are required. Only the McGregor Lake-Travers Reservoir-Little Bow Reservoir Block has representation of this theme (Table 37). There is insufficient land within this block that contains this theme and, therefore, it is unlikely that the targets can be met (ANHIC 1997). The Turin Dunes ESA also contains dune features, however, there are no blocks of crown land greater than $10 \mathrm{~km}^{2}$ in size in this area.

Recommendation: Consider protecting all available sites that have representation of this theme.

- Exposed slope: To meet the Level 1 NHT targets, $25 \mathrm{~km}^{2}$ of this theme are required. Several blocks could contribute to representation of this theme: Dorothy East, Majorville, McGregor Lake-Travers Reservoir-Little Bow Reservoir, Milk River Ridge-Twin River, Eagle ButteRed Rock Coulee, Manyberries Creek Badlands-Cypress Hills South and Milk RiverPakowki/Pinhorn-Black Butte (Table 37). The targets for this theme can probably be met from within these blocks.

Recommendation: Focus on the McGregor Lake-Travers Reservoir-Little Bow Reservoir Block in the Lethbridge Parcel, the Eagle Butte-Red Rock Coulee Block in the Cypress Hills Parcel and the Milk River-Pakowki/Pinhorn-Black Butte Block in the Sweetgrass Hills Parcel to ensure representation of this theme across its range of variation.

- Protected slope: To meet the Level 1 NHT targets, about $25 \mathrm{~km}^{2}$ of this theme are required. Several blocks could contribute to representation of this theme: Dorothy East, Milk River Ridge-Twin River, Eagle Butte-Red Rock Coulee and Milk River-Pakowki/Pinhorn-Black Butte (Table 37). The targets for this theme can probably be met from within these blocks.

Recommendation: Focus on the Milk River Ridge-Twin River Block in the Lethbridge Parcel, the Eagle Butte-Red Rock Coulee Block in the Cypress Hills Parcel and the Milk River-Pakowki/Pinhorn-Black Butte Block in the Sweetgrass Hills Parcel to ensure representation of this theme across its range of variation.

- Floor/Stream: To meet the Level 1 NHT targets, about $25 \mathrm{~km}^{2}$ of this theme are required. Several blocks could contribute to representation of this theme: Bluestem-Oldman-Macleod, Milk River Ridge-Twin River, Eagle Butte-Red Rock Coulee, Manyberries Creek BadlandsCypress Hills South and Milk River-Pakowki/Pinhorn-Black Butte (Table 37). The targets for this theme can probably be met from within these blocks.

Recommendation: Focus on the Bluestem-Oldman-Macleod Block and the Milk River Ridge-Twin River Block in the Lethbridge Parcel, the Manyberries Creek Badlands-Cypress Hills South Block in the Cypress Hills Parcel and the Milk River-Pakowki/Pinhorn-Black Butte Block in the Sweetgrass Hills Parcel to ensure representation of this theme across its range of variation. 
- Springs: To meet the Level 1 NHT targets, about $2.5 \mathrm{~km}^{2}$ of this theme are required. Several blocks could contribute to representation of this theme: Bluestem-Oldman-Macleod, Milk River Ridge-Twin River Block, Manyberries Creek Badlands-Cypress Hills South Block and the Milk River-Pakowki/Pinhorn-Black Butte Block (Table 37). The targets for this theme can probably be met from within these blocks.

Recommendation: Focus on the Bluestem-Oldman-Macleod Block and the Milk River Ridge-Twin River Block in the Lethbridge Parcel, on the Manyberries Creek BadlandsCypress Hills South Block in the Cypress Hills Parcel, and on the Milk RiverPakowki/Pinhorn-Black Butte Block in the Sweetgrass Hills Parcel to ensure representation of this theme across its range of variation.

- Wet meadow: To meet the Level 1 NHT targets, about $2.5 \mathrm{~km}^{2}$ of this theme are required. Several blocks could contribute to representation of this theme: Majorville, McGregor LakeTravers Reservoir-Little Bow Reservoir, Milk River Ridge-Twin River, Eagle Butte-Red Rock Coulee, Manyberries Creek Badlands-Cypress Hills South and Milk RiverPakowki/Pinhorn-Black Butte (Table 37). The targets for this theme can probably be met from within these blocks.

Recommendation: Focus on the Majorville Block and the Milk River Ridge-Twin River Block in the Lethbridge Parcel, on the Manyberries Creek Badlands-Cypress Hills South Block in the Cypress Hills Parcel and on the Milk River-Pakowki/Pinhorn-Black Butte Block in the Sweetgrass Hills Parcel to ensure representation of this theme across its range of variation.

- Shallow marsh: To meet the Level 1 NHT targets, about $2.5 \mathrm{~km}^{2}$ of this theme are required. Several sites could contribute to representation of this theme: Majorville, Milk River RidgeTwin River, Eagle Butte-Red Rock Coulee, Manyberries Creek Badlands-Cypress Hills South Block and Milk River-Pakowki/Pinhorn-Black Butte (Table 37). The targets for this theme can probably be met from within these blocks.

Recommendation: Focus on the Majorville Block and the Milk River Ridge-Twin River Block in the Lethbridge Parcel and on the Manyberries Creek Badlands-Cypress Hills South Block in the Cypress Hills Parcel and on the Milk River-Pakowki/Pinhorn-Black Butte Block in the Sweetgrass Hills Parcel to ensure representation of this theme across its range of variation.

- Deep marsh: To meet the Level 1 NHT targets, about $2.5 \mathrm{~km}^{2}$ of this theme are required. Three blocks could contribute to representation of this theme: Milk River Ridge-Twin River, Eagle Butte-Red Rock Coulee and Manyberries Creek Badlands-Cypress Hills South (Table 37). The targets for this theme can probably be met from within these blocks.

Recommendation: Focus on the Milk River Ridge-Twin River Block in the Lethbridge Parcel and on the Manyberries Creek Badlands-Cypress Hills South Block in the Cypress Hills Parcel to ensure representation of this theme across its range of variation. 
- Alkali wetland: To meet the Level 1 NHT targets, about $2.5 \mathrm{~km}^{2}$ of this theme are required. Three blocks could contribute to representation of this theme: Bluestem-Oldman-Macleod, Eagle Butte-Red Rock Coulee and Milk River-Pakowki/Pinhorn-Black Butte (Table 37). The targets for this theme can probably be met from within these blocks.

Recommendation: Focus on all three areas to ensure adequate representation of this theme across its range of variation. 


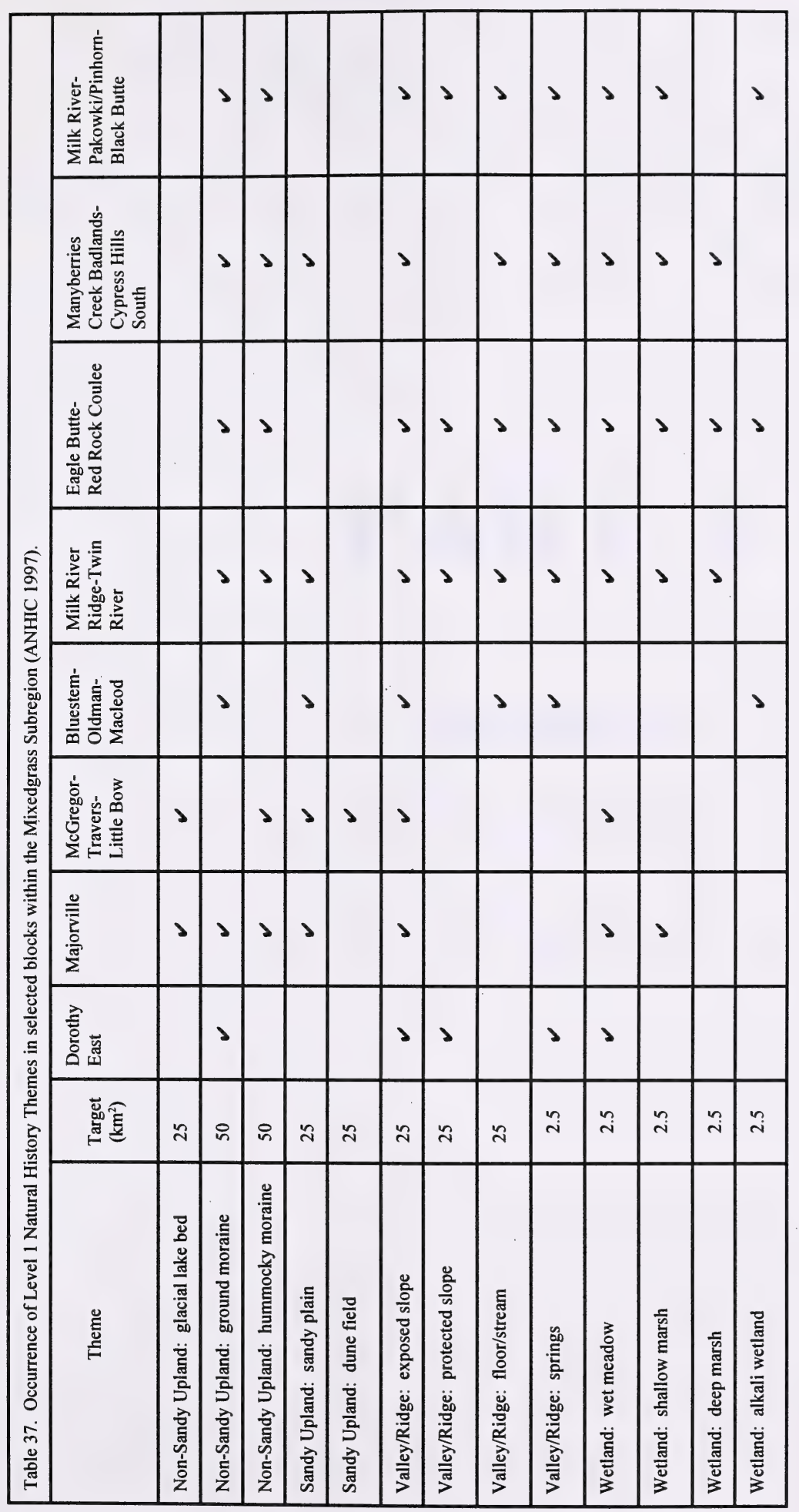

2 
E

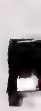

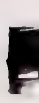

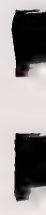

.

,

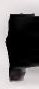

,

,

.

,

.

,

,

,

.

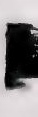


PART 3

Conclusion 
E

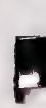

$-$

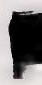

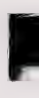

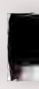

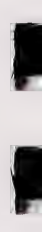

5

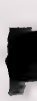

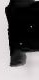

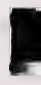

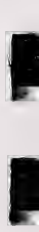

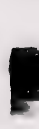

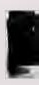

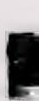

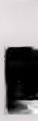

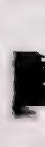




\section{Conclusion}

This report identifies priority sites for possible protected areas. These were identified using available information such as land ownership, remaining native prairie and levels of disturbance. This information was then intersected in a GIS environment with significance levels as identified through ESA studies. Table 38 lists the mostly non-lake areas in these priority sites. They are primarily sites that could make significant contributions to Level 1 Natural History Theme targets. Special features and themes are mentioned where the information is available, but many will not be included in protected areas if these are chosen based only on landscape representation criteria.

An overview of the Grasslands Region shows that extensive areas are no longer in native vegetation and remnant areas are becoming "islands". Some connecting corridors remain, particularly along rivers, but they too are progressively being fragmented. Of the four grassland subregions in Alberta, the Dry Mixedgrass is the largest and within it are the most extensive remaining native grasslands in the province. The southeast corner is the best remaining opportunity to maintain extensive grassland landscapes. The Foothills Fescue Subregion is the most highly impacted. Remaining blocks of greater than $50 \%$ native vegetation are found only on the Milk River Ridge and along the eastern slopes of the Porcupine Hills. Smaller blocks occur along the western boundary of the subregion. Only small portions are crown lands available for inclusion in a provincial protected areas program.

Reviewing available information on the grasslands shows that they have changed substantially. Extensive loss of habitat and fragmentation of those remaining is reflected in the loss of species. Changes in levels and timing of key ecosystem processes and loss of continuity of natural habitats further magnify the impacts of habitat loss. The integrity of the grassland landscape has been compromised. To restore the integrity of the prairie landscape and the species that use it and move through it, establishing protected areas in the grassland is a central component. A protected areas system alone, however, is not enough. Areas of remaining native vegetation outside protected areas should also be maintained, and restoration of corridors and habitat blocks is required. This is the domain of the many individuals, groups, agencies and industries who are presently working together to restore and conserve native prairie ecosystems.

\begin{tabular}{|c|c|c|c|}
\hline Subregion & $\begin{array}{l}\text { Size of subregion } \\
\left(\mathrm{km}^{2}\right)\end{array}$ & $\begin{array}{l}\text { Size of Priority Lands } \\
\qquad\left(\mathrm{km}^{2}\right)\end{array}$ & $\begin{array}{c}\text { Priority Lands as } \\
\% \text { of } \\
\text { Subregion }\end{array}$ \\
\hline Dry Mixedgrass & 46976 & 4111 & 8.7 \\
\hline Foothills Fescue & 14888 & 165 & 1.1 \\
\hline Northern Fescue & 15384 & 1366 & 8.8 \\
\hline Mixedgrass & 19177 & 2062 & 10.7 \\
\hline Total** & 96425 & 7704 & 8.0 \\
\hline \multicolumn{4}{|c|}{$\begin{array}{l}\text { *Priority lands include all crown and mixed land within selected provincially significant ESAs plus nationally } \\
\text { and internationally significant ESAs that have } 50 \% \text { or more remaining in native prairie (where native prairie } \\
\text { coverage is available). Lands within these ESAs that had high road }\left(>1.5 \mathrm{ha} / \mathrm{km}^{2}\right) \text { and wellsite }\left(>2 \text { wellsites } / \mathrm{km}^{2}\right) \\
\text { densities were excluded. } \\
{ }^{* *} \text { The totals here do not include waterbodies, due to the difficulty of determining land ownership status. Crown- } \\
\text { owned bed and shores of some waterbodies also need to be considered to meet gaps in the Grassland Natural } \\
\text { Region. }\end{array}$} \\
\hline
\end{tabular}


E

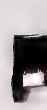

.

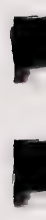

,

.

.

,

.

.

.

.

.

.

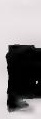

.
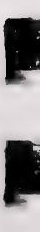
APPENDICES 


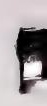

.

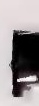

,

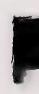

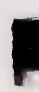

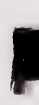

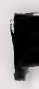

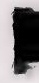

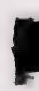

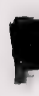

5

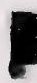

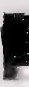

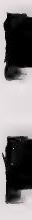

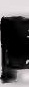

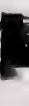


Appendix 1. List of the vascular plant, moss and animal species on the tracking lists that have been mapped as occurring within the Grassland Natural Region (ANHIC files, 1997).

\section{Dry Mixedgrass Subregion:}

Plant Species Name

Abronia micrantha .

Asclepias viridiflora

Castilleja sessiflora

Chenopodium watsonii

Cryptantha minima

Downingia laeta .

Halimolobos virgata

Jaffueliobryum raui

Lilaea scilloides

Munroa squarrosa

Oenothera andina

Polanisia dodecandra

Pterygoneurum ovatum

Tradescantia occidentalis

Weissia controversa

Yucca glauca

Astragalus kentrophyta var. kentrophyta

Chenopodium desiccatum

Leskea gracilescens

Allium geyeri

Asclepias ovalifolia

Astragalus lotiflorus

Astragalus purshii

Bidens frondosa

Boisduvalia glabella

Carex deflexa

Carex nebraskensis

Chenopodium subglabrum

Crepis atrabarba

Crepis occidentalis

Cyperus schweinitzii

Danthonia unispicata

Draba reptans

Eriogonum cernuum

Franseria acanthicarpa

Linanthus septentrionalis

Lygodesmia rostrata

Muhlenbergia asperifolia

Nothocalais cuspidata

Oenothera serrulata

Osmorhiza longistylis

Polygonum watsonii

Potentilla paradoxa

Psilocarphus elatior
Species Common Name

sand verbena

green milkweed

downy paintbrush

Watson's goosefoot

small cryptanthe

downingia

halimolobos

flowering-quillwort

false buffalo grass .

upland evening-primrose

clammyweed

hairy-leaved beardless moss

western spiderwort

green-cushioned weissia

soapweed

prickly milk vetch

goosefoot

Geyer's onion

low milkweed

low milk vetch

Pursh's milk vetch

common beggarticks

smooth boisduvalia

bent sedge

Nebraska sedge

smooth narrow-leaved goosefoot ......S

hawk's-beard ................ S2

small-flowered hawk's-beard ........ S2

sand nut-grass . . . . . . . . . . S2

one-spike oat grass $\ldots \ldots \ldots \ldots \ldots$. . . 2

whitlow-grass .............. S2

nodding umbrella-plant ........... S2

bur ragweed ................. S2

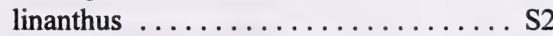

annual skeletonweed ............ S2

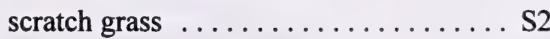

prairie false dandelion ........... S2

shrubby evening-primrose ......... S2

smooth sweet cicely $\ldots \ldots \ldots \ldots \ldots$ S2

Watson's knotweed ............. S2

bushy cinquefoil ............. S2

woollyheads $\underline{\text { S-Rank }}^{*} \quad \underline{\text { G-Rank }}$

$\mathrm{S} 1 \ldots \ldots \mathrm{G} 5$

$\mathrm{S} 1 \ldots \ldots \mathrm{G} 5$

S1 ........ G5

$\mathrm{S} 1 \ldots \ldots \mathrm{G} 5$

S1 ........ G5

$1 \ldots . . .6 \mathrm{G} 5$

$1 \ldots . . . .6 \mathrm{G} 4$

$1 \ldots . . . . \mathrm{G} 4$ ?

$1 \ldots . . .6 \mathrm{G} 4$

$1 \ldots \ldots$ G5

$1 \ldots . . . . . \mathrm{G} 4$

$1 \ldots \ldots . . .65$ G

$\ldots \ldots$ G5

$\ldots \ldots$ G5

$\ldots \ldots$ G5

....... G5

$2 \ldots . . . . \mathrm{G} 5 \mathrm{~T} 3 \mathrm{~T} 4$

$2 \ldots . . \mathrm{G} 5$

$\ldots \ldots . . .65$

....... G4G5

G3G5

G5

G5

G5

G5

G5

G5

G3

G5

G5

G5

G5

G5

G5

G5

G5

G5?

G5

G5

G5

G5

G3G4

G5

G5 


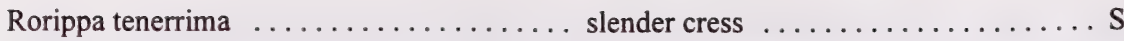

$\mathrm{S} 2 \ldots \ldots \mathrm{G} 5$

Spergularia marina $\ldots \ldots \ldots \ldots \ldots \ldots$ salt-marsh sand spurry $\ldots \ldots \ldots \ldots . \mathrm{S}_{2}$

Stephanomeria runcinata $\ldots \ldots \ldots \ldots \ldots$ rush-pink $\ldots \ldots \ldots \ldots \ldots \ldots$ S

$\mathrm{S} 2 \ldots \ldots \ldots$

Suaeda moquinii . ................ Moquin's sea-blite $\ldots \ldots \ldots \ldots \ldots$ S2 $\ldots \ldots \ldots$ G5

Suckleya suckleyana $\ldots \ldots \ldots \ldots$. . poison suckleya $\ldots \ldots \ldots \ldots \ldots$ S2 $\ldots \ldots \ldots$ G5

Oenothera flava

low yellow evening-primrose

S2?...... G5

Animal Species Name

Species Common Name

$\underline{\text { S-Rank }}$

G-Rank

Rana pipiens

northern leopard frog

S2

\section{Foothills Fescue Subregion:}

\section{Plant Species Name}

Brachythecium reflexum

Desmatodon cernuus

Physcomitrium hookeri

Hymenopappus filifolius

Iris missouriensis

Orthotrichum pumilum

Corispermum nitidum

Allium geyeri

Amaranthus californicus

Aster campestris

Aulacomnium androgynum

Carex crawei

Carex parryana var. parryana

Carex raynoldsii

Carex rostrata

Carex vesicaria

Castilleja cusickii

Conimitella williamsii

Cypripedium montanum

Desmatodon heimii

Elodea longivaginata

Erigeron radicatus

Fissidens grandifrons

Juncus confusus

Lithophragma glabrum

Lomatogonium rotatum

Montia linearis

Plantago canescens

Veronica catenata

Acer negundo

Carex hoodii

Oenothera flava

Animal Species Name

Rana pipiens

\section{Species Common Name}

$\underline{\text { S-Rank }}$

\section{S1}

narrow-leafed chain-teeth moss

$\mathrm{S} 1$

bladder-cap moss

tufted hymenopappus

western blue flag

bugseed

Geyer's onion

Californian amaranth

meadow aster

Crawe's sedge

Parry's sedge

Raynold's sedge

beaked sedge

blister sedge

yellow paintbrush

conimitella

mountain lady's-slipper

long-stalked beardless moss

Canada waterweed

dwarf fleabane

narrow-leaved Chinese phoenix moss .

few-flowered rush

rockstar

marsh felwort

linear-leaved montia

western ribgrass

water speedwell

Manitoba maple

Hood's sedge

low yellow evening-primrose

Species Common Name

northern leopard frog $\underline{\text { S-Rank }}$

\section{S1}

S1S2

S1S2

S1S2

$\mathrm{S} 1$ ?

S2

$\mathrm{S} 2$

$\mathrm{S} 2$

$\mathrm{S} 2$

$\mathrm{S} 2$

$\mathrm{S} 2$

$\mathrm{S} 2$

$\mathrm{S} 2$

$\mathrm{S} 2$

$\mathrm{S} 2$

$\mathrm{S} 2$

$\mathrm{S} 2$

$\mathrm{S} 2$

$\mathrm{S} 2$

$\mathrm{S} 2$

$\mathrm{S} 2$

$\mathrm{S} 2$

$\mathrm{S} 2$

S2

$\mathrm{S} 2$

S2

$\mathrm{S} 2$

$\mathrm{S} 2$ ?

S2?

S2?

S2 $\underline{\text { G-Rank }}$

G4G5

G3G5

G2G4

G5

G5

G5

G5

G4G5

G4

G5

G5

G5

G4T4

G5

G5

G5

G4G5

G3

G4G5

G5

G4G5

G3

G3G5

G5

G4G5

G5

G5

G4G5

G5

G5

G4G5

G5

G-Rank

G5 


\section{Northern Fescue Subregion:}

Bryum marratii

Allium geyeri

Geyer's onion

Populus angustifolia

narrow-leaf cottonwood

Potentilla plattensis

low cinquefoil

$\mathrm{S} 2$

Acer negundo

Manitoba maple

$\mathrm{S} 2 ?$

G5

Animal Species Name

Species Common Name

$\underline{\text { S-Rank }}$

$\underline{\text { G-Rank }}$

Rana pipiens

northern leopard frog

S2

\section{Mixedgrass Subregion:}

\section{Plant Species Name}

Downingia laeta

Polanisia dodecandra

Antennaria corymbosa

Iris missouriensis

Astragalus lotiflorus

Carex nebraskensis

Castilleja cusickii

Chenopodium subglabrum

Coreopsis tinctoria

Crepis occidentalis

Danthonia unispicata

Draba reptans

Fontinalis antipyretica

Juncus confusus

Lithophragma glabrum

Lygodesmia rostrata

Melica subulata

Mertensia lanceolata

Nemophila breviflora

Phacelia linearis

Populus angustifolia

Rorippa tenerrima

Ruppia maritima

Schizachyrium scoparium var. scoparium

\section{Animal Species Name}

Rana pipiens .

Lasiurus cinereus

\section{Species Common Name}

downingia

$\underline{\text { S-Rank }}$

$\underline{\text { G-Rank }}$

c..................... S1

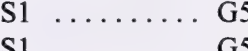

........ G5Q

corymbose everlasting $\ldots \ldots \ldots \ldots$ S1S2 $\ldots \ldots \ldots$ G5

western blue flag $\ldots \ldots \ldots \ldots \ldots \ldots$ S1S2 $\ldots \ldots \ldots$ G5

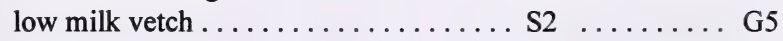

Nebraska sedge $\ldots \ldots \ldots \ldots \ldots \ldots$ S2 $\ldots \ldots \ldots$ G5

yellow paintbrush $\ldots \ldots \ldots \ldots \ldots$ S2 $\ldots \ldots \ldots$ G4G5

smooth narrow-leaved goosefoot $\ldots \ldots$ S2 $\ldots \ldots \ldots$ G3

common tickseed $\ldots \ldots \ldots \ldots \ldots$. S2 $\ldots \ldots \ldots$ G5

small-flowered hawk's-beard $\ldots \ldots \ldots$ S2 $\ldots \ldots \ldots$ G5

one-spike oat grass $\ldots \ldots \ldots \ldots \ldots$ S2 $\ldots \ldots \ldots$ G5

whitlow-grass $\ldots \ldots \ldots \ldots \ldots \ldots$ S2 $\ldots \ldots \ldots$ G5

$\ldots \ldots \ldots \ldots \ldots \ldots \ldots \ldots$ S2 $\ldots \ldots \ldots \ldots$ G5

few-flowered rush $\ldots \ldots \ldots \ldots \ldots$. S2 $\ldots \ldots \ldots$ G5

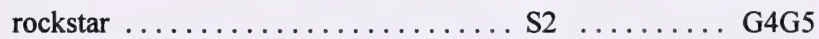

annual skeletonweed $\ldots \ldots \ldots \ldots \ldots$ S2 $\ldots \ldots \ldots$ G5?

Alaska onion grass $\ldots \ldots \ldots \ldots \ldots$ S2 $\ldots \ldots \ldots$ G5

lance-leaved lungwort .......... S2 ...... G5

small baby-blue-eyes ........... S2 ....... G5

linear-leaved scorpionweed ........ S2 $\ldots \ldots \ldots$ G5

narrow-leaf cottonwood ........... S2 ....... G5

slender cress $\ldots \ldots \ldots \ldots \ldots \ldots \ldots$ S2 $\ldots \ldots \ldots$ G5

widgeon-grass $\ldots \ldots \ldots \ldots \ldots \ldots \ldots$ S2 $\ldots \ldots \ldots$ G5

little bluestem $\ldots \ldots \ldots \ldots \ldots \ldots$ S2 $\ldots \ldots \ldots$ G5T?

Species Common Name $\quad \underline{\text { S-Rank } \quad \text { G-Rank }}$

northern leopard frog $\ldots \ldots \ldots \ldots \ldots$ S2 $\ldots \ldots \ldots$ G5

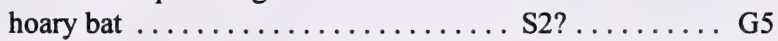




\section{* NOTE:}

S1 $=\leq 5$ occurrences in the province

S2 $=6-20$ occurrences in the province

$\mathrm{S} ?=$ rank questionable

$\overline{\mathrm{G}} \overline{\mathrm{G}}=6-20$ occurrences

$\mathrm{G} 3=21-100$ occurrences

$\mathrm{G} 4=$ typically $>100$ occurrences but may be fewer with many large populations

$\mathrm{G} 5=>100$ occurrences, may be rare in parts of its range

? = rank questionable

Q = taxonomic questions or problems

$\overline{\mathrm{T}}_{-}=$rank for a subspecific taxon 


\section{Appendix 2. Environmentally Significant Areas}

The following discussion has been taken primarily from the July 1996 report entitled, "Selecting Protected Areas: the Foothills Natural Region of Alberta" (Alberta Environmental Protection 1996).

From a Canadian perspective, the groundwork for Environmentally Significant Area [ESA] research was laid by various researchers at the University of Guelph, with the Environmentally Sensitive Areas studies of Eagles (e.g., Eagles 1984) being particularly influential. Subsequent workers have freely adopted and adapted ESA terminology, definitions and identification criteria developed by Eagles (1984) and others, for use with ESAs.

"Although ESAs have traditionally focussed on site-specific biotic (vegetation, wildlife), abiotic (geology, hydrology), or, to a lesser extent, recreational criteria, the concept of environmental significance has become more broadly defined to include greater consideration of ecological processes and ecosystem integrity" (Bentz et al. 1995, p. iii).

Based upon the work of Eagles (1984), Geowest Environmental Consultants Ltd (1996), Sweetgrass Consultants Ltd. (1994) and others, 'criteria' have been developed by which environmentally significant areas can be identified. These criteria include:

- areas that contain large or relatively undisturbed habitats and provide shelter habitat for species which are intolerant of disturbances;

- areas that contain plants, animals, or landforms which are unusual or are of local, regional, provincial, national, or international significance;

- areas that are excellent representatives of one or more ecosystems or landscapes that characterize a natural region;

- areas that contain an unusual diversity of plant and/or animal communities due to a variety of geomorphological features and microclimatic effects;

- areas that are unique habitats with limited representation in the region, or areas that represent small remnants of previously abundant habitats which have virtually disappeared;

- areas that contain significant, rare, or endangered plant and animal species;

- areas that contain unique geological or physiographic features;

- areas that provide an important linking function and permit the movement of wildlife over considerable distances;

- areas that perform a vital environmental, ecological, or hydrological function (e.g., aquifer recharge or groundwater storage area); 
- hazard lands and areas that are unsuitable for development in their natural state (e.g., floodplains, steep and unstable slopes);

- areas with lengthy histories of scientific research;

- areas with intrinsic appeal due to widespread community interest or the presence of highly valued features or species such as game species or sport fish; or

- areas, buildings, or features that are important for cultural or historic reasons.

As ESAs are identified their overall level of environmental significance must also be determined. This process "requires considerable knowledge of significant features both within ... and outside" the Natural Region of interest (Bentz et al. 1995) and a certain degree of subjectivity is inevitably involved in such judgments. The ESA significance categories and definitions "adopted by resource management agencies in Alberta" (ibid.) and used by Geowest Environmental Consultants Ltd. (1996) are based upon those originally developed by Eagles (1984) for Environmentally Sensitive Areas, namely:

international - features which are unique in the world

national - features which are limited in distribution at a national level or which are the best and only representatives in Canada

provincial - features which are of limited distribution in Alberta or are the best examples of a particular feature in Alberta

regional - features which are of limited distribution in the Grasslands Natural Region or are the best examples of a feature in the Grasslands Natural Region.

Another very important consideration is the fact that the significance of any ESA is also relative to the condition of the lands surrounding it and can be strongly influenced (usually adversely) by the patterns of use/types and levels of activity occurring upon those lands. In the Grasslands Natural Region, considerable environmental change has occurred, and is still occurring. Thus, the theoretical published significance level for any given ESA may not necessarily match the current reality 'on-site'. Since most Grasslands ESAs have no legislated protective status, their significance levels may change quickly. Several of the Region's ESAs have already been considerably impacted by various land-use activities, to an extent that their consideration as candidate protected areas may have been precluded.

According to Geowest Environmental Consultants [GEC] Ltd. (1996, p7), in order to properly assess the overall significance level of a potential ESA, four factors regarding the physical state of the site i.e., its representivity; diversity; ecological integrity and naturalness, must be considered. With respect to 'representivity', "features or sites are evaluated according to the degree to which they represent that type of feature within ... the Grasslands Natural Region"... 
"the representivity criterion is intended to provide context" (ibid.). It should be noted however, that as the whole landscape becomes more degraded, "ESAs" identified within it over time, can be less and less representative of the region's original ecological baseline.

Relative to 'ecological' diversity, a site is evaluated primarily on its physiographic diversity. Thus, according to GEC (1996), "areas with dramatic relief, varied exposures, and heterogeneous substrates usually exhibit greater ecological diversity than areas of comparable size that are more homogeneous in nature and possess narrower ecological gradients." Further, "the ecological integrity of each potential ESA site is integral to ensure the incorporation of whole viable systems into the protected areas network, thereby minimizing potentially negative impacts of extrinsic biophysical processes and anthropogenic activities" (GEC 1996). Specific factors which contribute to ecological integrity include size, distribution, shape, compatibility of adjacent land uses, watershed completeness, replication, and intended use and manageability. GEC asserts that a consideration of ecological integrity is particularly important for the wetland, riparian, and aquatic components of the Grassland Natural Region.

Regarding 'naturalness', GEC (1996, p8) states the following: "The degree of anthropogenic disturbance is an important factor in determining the suitability of a site for inclusion as an environmentally significant area. ... protected areas should be located in areas that have experienced a minimal degree of development and/or disturbance ... Mineral extraction, agriculture conversion, grazing, human habitation, and hunting and trapping are some examples of disturbances which have been used in the past to disqualify candidate ESA sites." These authors (ibid.) believe that "Since some form and level of disturbance has occurred over a great deal of the Grasslands Natural Region, some potential ESA sites must be assessed with regards to their ability to recover to a natural state following designation within a protected areas system." While this assertion has merit for future potential buffer zones or sites designed to meet other (non-preservation) goals of Special Places, it is inappropriate for the "core reserve"-quality sites being considered here. This is because the most valuable and significant protected areas are those whose ecological diversity, when they are established, most closely resembles that of their original, natural and pristine state ( $c f$. Noss and Cooperrider 1994; and many others).

Examples of grasslands-related, regionally, provincially and nationally significant environmental features as provided by Geowest Environmental Consultants Ltd. (1996, p10) and Wallis (1996), are listed in the chart below. In this chart, "significant populations" of rare plants or animals generally refers to populations that are self-sustaining. Occurrences of individuals or single nest sites are not considered significant unless they are one of very few localities for the species in Alberta. 
- habitats supporting populations of plants or animals that are rare in the region (e.g. swift fox, colonial nesting birds)

- $\quad$ areas of unusually high landform, vegetation, or wildlife diversity

- lakes supporting commercial, domestic, or sport fisheries

- $\quad$ rivers or streams supporting spawning populations of important sport fish species

- $\quad$ important wintering areas for ungulates such as moose and mule deer

- critical wildlife movement corridors

- landforms, landscapes or geological features that are uncommon or rare or the best examples of their types in the Grassland Natural Region.

- habitats supporting significant populations of plants or animals that are rare or uncommon in Alberta (e.g., piping plover, burrowing owl)

- $\quad$ rare plants and native plant communities that are among the best examples of their type in Alberta

- areas of unusually high landform, vegetation, or wildlife diversity including native habitat assemblages that are among the best examples of their type in the province.

- provincially designated protected areas

- relatively undisturbed and sizable remnants of natural habitat that elsewhere in Alberta have been disturbed by various forms of development

- landforms, landscapes or geological features that remain in a natural state and that are the best examples of their types in Alberta.

- landforms, landscapes or geological features which are rare in Alberta.

- $\quad$ areas designated as provincially important by other agencies

- critical ungulate habitats which are considered to be some of the most important in Alberta.

- $\quad$ rivers which are among the best sport fish production streams in Alberta.

- extensive, relatively intact native grasslands

- $\quad$ old-growth forests that are the largest or best representatives in Alberta.

- interprovincial rivers

- $\quad$ extensive and diverse riparian woodlands and shrubbery

- deepest river canyons/most diverse river valley systems in Canada

- excellent representation of transverse sand dune forms

- $\quad$ nationally designated protected areas (e.g., national parks, NWAs)

- $\quad$ areas designated as nationally important by other agencies

- critical ungulate habitats which are considered to be some of the most important in North America

- large, intact remnants of ecosystems that have been largely developed (e.g., northern fescue grassland)

- habitats supporting breeding populations of nationally endangered species (e.g., piping plover, mountain plover)

- $\quad$ areas which support some of the largest or only populations of rare plants or animals in Canada

- $\quad$ nationally rare geologic features (e.g., igneous intrusive dikes on plains)

- $\quad$ areas which support natural habitat types which are rare in Canada

- relatively undisturbed and sizeable remnants of natural habitats which, elsewhere in Canada, have mostly been disturbed by development

- landforms, landscapes or geological features which are the best examples of their types in Canada

- $\quad$ rivers which are among the best sport fish production streams in Canada

- type localities for geology and biology (e.g., geological formations, fossils, plants or animals)

- largest, most intact remnants of ecosystems that have been largely developed throughout their range (e.g., northern fescue grassland)

- habitats supporting significant breeding populations of internationally endangered species (e.g., piping plovers) 


\section{LITERATURE}

CITED and OTHER

REFERENCES 


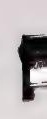

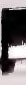

.

,

,

,

,

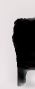

,

,

,

,

,

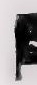

,

,

,

1 
AAFC. 1995. Soil Landscapes of Canada, Version 2.1. National Soil Database, Agriculture and Agri-Food Canada.Achuff, P.L., J. Godfrey and W. Wallis. 1988. Natural Regions of Alberta: Annotated Bibliography. Protected Areas Report No. 4. Prepared for Alberta Recreation and Parks, Edmonton, AB., 112 pp.

Achuff, P.L. 1992. Natural Regions, subregions and Natural History Themes of Alberta: A classification for protected areas management. Report No. 2. Prepared for Parks Services and Natural \& Protected Areas, Alberta Government. Revised and updated December 1994.

Achuff, P.L., and C. Wallis. 1992. Natural Regions and Natural History Themes: Targets for Alberta. Protected Areas Report No.3. Prepared for Alberta Tourism, Parks and Recreation and Alberta Forestry, Lands and Wildlife, Edmonton, AB., 71 pp.

Adams, B.W., W. Willms and M. Powell. 1993. Sustainable rangeland management--aligning livestock with the ecosystem. In: Proceedings of the International Workshop on Sustainable Land Management for the 21st Century (Volume 2: plenary papers). University of Lethbridge. Lethbridge, Canada. June 20-26, 1993.

AEC. 1996 (July). Cattle and the oil and gas industry in Alberta: a literature review with recommendations for environmental management. Prepared by the Alberta Environmental Centre (AEC) for the Alberta Cattle Commission, Calgary.

AEP. 1996. The Status of Alberta Wildlife. Prepared by Wildlife Management Division; Natural Resources Service; Alberta Environmental Protection; Edmonton, Alberta. 44pp.

AFGA. 1993. Final Report: Operation Burrowing Owl, Alberta. Prepared by the Alberta Fish and Game Association. 19pp + appendices.

AFRD. 1992. GIS data re. "southern region native prairie vegetation". Prepared by Alberta Agriculture, Food and Rural Development. Hardcopy map scale 1:350,000.

AHJV. 1989 (January). The Alberta Habitat Joint Venture--A Planning Document. Prepared by Alberta Forestry, Lands and Wildlife; Canadian Forestry Service; Alberta Agriculture and Ducks Unlimited Canada.

Alberta Energy and Utilities Board (EUB). 1996. Alberta's energy resources: 1995 in review. Website addresses@http://www.eub.gov.ab.ca/bbs/inf/stat/st-96-40.b.html. and http://borg.energy.gov.ab.ca/dept/annrp.htm\#Energy and the enviro.

Alberta Environmental Protection. 1994a. Alberta's State of the Environment Comprehensive Report. Prepared by Dept. of Environmental Protection; Edmonton, AB. 119pp.

Alberta Environmental Protection [AEP]. 1994b. Alberta Protected Areas System Analysis (1994). Report 3: Revised by Achuff December 7, 1994; Edmonton, Alberta.

Alberta Environmental Protection. 1995 (August). Alberta's threatened wildlife. Brochure prepared by Natural Resources Service. 
Alberta Environmental Protection. 1996 (July). Selecting protected areas: the Foothills Natural Region of Alberta. Prepared for the Special Places Provincial Coordinating Committee. $77 \mathrm{pp}$. + maps and photos.

Alberta Environmental Protection. 1996a. Alberta 1996 State of the Environment Report: Aquatic Ecosystems. Draft report No. 4. Prepared by Strategic \& Regional Support Division, Alberta Environmental Protection.

Alberta Forestry, Lands and Wildlife. n.d. Alberta's Landowner Habitat Program. Brochure prepared by the Fish and Wildlife Division.

Alberta Forestry, Lands and Wildlife. 1990. Alberta's threatened wildlife-Piping Plover. Brochure prepared by the Fish and Wildlife Division.

Alberta Forestry, Lands and Wildlife. 1991. The status of Alberta wildlife. Prepared by Wildlife Management Branch, Fish and Wildlife Division, Edmonton.

Alberta NAWMP Centre. 1993. A strategy to assist Alberta Transportation and Utilities in developing environmental guidelines to apply to their activities--a proposal. Prepared by the North American Waterfowl Management Plan Centre, Edmonton.

Alberta Prairie Conservation Forum. 1995 (November). Prairie Conservation. A bulletin from the Alberta Prairie Conservation Forum. 4pp.

Alberta Soil Survey Unit Staff. 1991. Soil landscapes of Canada-Alberta; Soil landscapes polygon attribute digital data; CanSIS No. AL088200, version 91.11.30; CLBRR Archive, Agriculture Canada, Research Branch, Ottawa, Canada (CLBRR Contribution No. 91-106D).

Alberta Water Resources Commission. 1987. Drainage potential in Alberta: an integrated study. Prepared by AWRC in concert with Alberta Departments of Agriculture, Environment and Forestry, Lands and Wildlife.

Alberta Water Resources Commission. 1993a. Beyond prairie potholes: a draft policy for managing Alberta's peatlands and non-settled area wetlands. $15 \mathrm{pp}$.

Alberta Water Resources Commission. 1993b. Wetland management in the settled area of Alberta: an interim policy. $14 \mathrm{pp}$.

Anderson, M.G., R.B. Fowler and J.W. Nelson. 1995. Northern grassland conservation and the Prairie Joint Ventures. In. Transactions of the Sixtieth North American Wildlife and Natural Resources Conference, March 24-29, 1995; Minneapolis, Minn.; pp404-412.

Anderson, S.H., K. Mann and H.H. Shugart, Jr. 1977. The effect of transmission line corridors on bird populations. American Midland Naturalist 97(1):216-221.

Angermeier, P.L. and J.R. Karr. 1994. Biological integrity versus biological diversity as policy directives: protecting biotic resources. BioScience 44(10):690-697. 
ANHIC. 1996a. Alberta Natural Heritage Information Centre (files). Recreation \& Protected Areas Division, Alberta Environmental Protection.

ANHIC. 1996b. Plant species of special concern. Alberta Natural Heritage Information Centre; Edmonton, Alberta. 32pp.

ANHIC. 1997. Digital database for nationally, provincially and internationally significant ESAs in Alberta. Recreation \& Protected Areas Division, Alberta Environmental Protection.

Anon. 1996. Emigrant life in Kansas; Chapter VII: Grasshoppers. Website address is http://history.cc.ukans.edu/carrie/kancoll/books/ebbutt/echap7.html

Avian Science and Conservation Centre. 1996. Saving the Loggerhead Shrike. Recovery-An Endangered Species Newsletter; Fall issue; Canadian Wildlife Service, Ottawa.

Banfield, A.W.F. 1974. The Mammals of Canada. University of Toronto Press, Toronto, Ontario.

Barrett, M.H. 1978. The impact of a severe winter on northern pronghorn ranges. In: Proceedings of the Eighth Biennial Pronghorn Antelope Workshop. Alberta Recreation, Parks and Wildlife, Edmonton, Alberta. pp. 337-359.

Barrett, M.W. 1982. Ranges, habitat and mortality of pronghorns at the northern limits of their range. Ph.D. thesis. Univ. of Alberta. 226pp.

Baydack, R.K., J.H. Patterson, C. Rubec, A. Tyrchniewicz and T.W. Weins. 1995. Management challenges for Canadian prairie grasslands in the 21st century. In. Transactions of the Sixtieth North American Wildlife and Natural Resources Conference, March 24-29, 1995; Minneapolis, Minn.; pp386-396.

Bentley. 1988 (December). Overview of agriculture in the prairie-parkland. Address given to the annual joint meeting of the Public Advisory Committees of the Environment Council of Alberta., Edmonton. 36pp.

Bentz, J.A., Saxena, A. and T.T. Normand. 1995. Environmentally Significant Areas Inventory. Foothills Natural Region, Alberta. Geowest Environmental Consultants Ltd., Edmonton, AB., 142 pp. + Appendices, + Map.

Biodiversity Working Group. 1994 (November). Canadian Biodiversity Strategy -- Canada's response to the Convention on Biological Diversity. Prepared by the Federal-ProvincialTerritorial Biodiversity Convention Office, Environment Canada, Hull, QE., 62 pp.

Biodiversity Working Group. 1994a. Draft Canadian Biodiversity Strategy. Biodiversity Convention Office, Environment Canada, Hull, QE., 61 pp. (Draft for discussion purposes February 28, 1994.) 
Bird, R.D. 1961. Ecology of the aspen parkland of Western Canada in relation to land use. Can. Agric. Publ. 1066:(II)I,X, 155pp.

Bjorge, R.R. 1987. Bird kill at an oil industry flare stack in northwest Alberta. Can. Field Nat. 101(3):346-350.

Blair, R.B. 1996. Land use and avian species diversity along an urban gradient. Ecological Applications. Vol.6(2):506-519.

Bleich, V.C., J.D. Wehausen and S.A. Holl. 1990. Desert-dwelling mountain sheep: conservation implications of a naturally fragmented distribution. Conserv. Biol. 4(4):383390.

Bollinger, E. K. 1995. Successional changes and habitat selection in hayfield bird communities. The Auk 112(3):720-730.

Bowen, B.S. and A.D. Kruse. 1993. Effects of grazing on nesting by Upland sandpipers in south-central North Dakota. J. Wildl. Mgmt. 57(2):291-301.

Brace, R.K. and G.W. Pepper. 1984. Impact of agricultural drainage on wildlife. Western Provincial Conference on Soil and Water Management. 22pp.

Bradley, C. 1996. Noah's ecosystem: we can't save endangered species one at a time. Recovery-An Endangered Species Newsletter; Fall issue; Canadian Wildlife Service, Ottawa.

Bradley, C. and C. Wallis. 1996 (February). Prairie ecosystem management: an Alberta perspective. Published by Prairie Conservation Forum, Occasional Paper No. 2; 29pp.

Brechtel, S.H. 1981. A status report, management proposal and selected bibliography for the White Pelican, Double-crested Cormorant and Great Blue Heron in Alberta - 1980. Unpubl. report, prep. for Fish and Wildlife Division, Alberta Energy and Natural Resources. 113pp.

Bredy, J. 1995 (May). Waterfowl Breeding Population Survey: southern and central Alberta. Data supplied by the United States Fish \& Wildlife Service, Canadian Wildlife Service, Alberta Fish \& Wildlife Division.

Bromley, M. 1985. Wildlife management implications of petroleum exploration and development in wildland environments. Gen. Tech. Report INT-191. Ogden, UT: U.S. Dept. of Agric., Forest Service, Intermountain Research Station, 42pp.

Brown, M. and J.J. Dinsmore. 1986. Implications of marsh size and isolation for marsh bird management. J. Wildl. Manage. 50:392-397.

Burnham, W.A. and T.J. Cade. 1995. Raptor populations: the basis for their management. In. Transactions of the Sixtieth North American Wildlife and Natural Resources Conference, March 24-29, 1995; Minneapolis, Minn.; pp115-130. 
Burnett, J.A., C.T. Dauphine Jr., S.H. McCrindle and T. Mosquin. 1989. On the brink: endangered species in Canada. Western Producer Prairie Books, Saskatoon, Sask.

Calverley, B. 1993 (September). Preliminary investigation of the incidence of female duck mortality during haying. Prepared by Alberta NAWMP Centre and Ducks Unlimited Canada.

Campbell, R.W., N.K. Dawe, I. McTaggart-Cowan, J.M. Cooper, G.W. Kaiser and M.C.E. McNall. 1990. The Birds of British Columbia. Vol. I. Introduction and Loons through Waterfowl. Published by the Royal British Columbia Museum in association with Environment Canada, Canadian Wildlife Service.

Campbell, R.W., N.K. Dawe, I. McTaggart-Cowan, J.M. Cooper, G.W. Kaiser and M.C.E. McNall. 1990a. The Birds of British Columbia. Vol. II. Diurnal Birds of Prey through Woodpeckers. Published by the Royal British Columbia Museum in association with Environment Canada, Canadian Wildlife Service.

Canadian Council on Ecological Areas. 1992. A Framework for Developing a Nation-wide System of Ecological Areas. Part 1: A Strategy. Can. Council on Ecol. Areas, Ottawa, ON., 10 pp.

Canadian Environmental Advisory Council. 1991. A Protected Areas Vision for Canada. Canadian Environmental Advisory Council, Environment Canada, Ottawa. 88pp.

CCEA. 1995. An introduction to Canadian Ecozones. Brochure prepared by the Canadian Council on Ecological Areas.

Christiansen, P.A. 1990. Alien species cover on the perimeter of two northwest Iowa prairies. In. Proceedings of the 12th North American Prairie Conference; August 1990; Cedar Falls, Iowa.

Coffin, D.P., W.K. Lauenroth and I.C. Burke. 1996. Recovery of vegetation in a semi-arid grassland 53 years after disturbance. Ecol. Applic. 6(2):538-555.

Cooperrider, A.Y. 1994 (Summer). Saving Nature's Legacy. How can our public and private lands best be managed to protect biological diversity? Defenders 69(3):17-24.

Corkal, D. and H.G. Peterson. 1994. Prairie surface water quality initiative-a joint federal, provincial, and industry approach to produce safe and palatable drinking water from small reservoirs on the prairies. Proceedings of the 6th National Conference on Drinking Water; Victoria, B.C.

Cornwell, G and H.A. Hochbaum. 1971. Collisions with wires-a source of anatid mortality. Wilson Bulletin 83(3):305-306.

COSEWIC. 1996 (April). Canadian species at risk. Prepared by the Committee on the Status of Endangered Wildlife in Canada. 
Cottonwood Consultants Ltd. 1983. A Biophysical Systems Overview for Ecological Reserves Planning in Alberta. Prepared for Alberta Recreation and Parks, Edmonton, AB., 365 pp.

Cottonwood Consultants Ltd. 1987a. County of Warner Environmentally Significant Areas. Prepared for Alberta Forestry, Lands \& Wildlife; Edmonton. Vol. 1 (37pp) and Vol. 2 (42pp).

Cottonwood Consultants Ltd. 1987b. M.D. of Pincher Creek Environmentally Significant Areas. Prepared for Alberta Forestry, Lands \& Wildlife; Edmonton. Vol. 1 (34pp) and Vol. $2(37 \mathrm{pp})$.

Cottonwood Consultants Ltd. 1987c. County of Lethbridge Environmentally Significant Areas. Prepared for Alberta Forestry, Lands \&.Wildlife; Edmonton. (37pp) and Vol. 2 (35pp).

Cottonwood Consultants Ltd. 1987d. Environmentally Significant Areas in the Oldman River Region: M.D. of Cardston. Prepared for Alberta Forestry, Lands \& Wildlife; Edmonton. (38pp) and Vol. 2 (26pp).

Cottonwood Consultants Ltd. 1988a. Environmentally Significant Areas in the Oldman River Region: County of Vulcan. Prepared for Alberta Forestry, Lands \& Wildlife and the Oldman Regional Planning Commission. Vol. 1 (29pp) and Vol. 2 (31pp).

Cottonwood Consultants Ltd. 1988b. Environmentally Significant Areas in the Oldman River Region: M.D. of Taber. Prepared for Alberta Forestry, Lands \& Wildlife and the Oldman Regional Planning Commission. Vol. 1 (29pp) and Vol. 2 (35pp).

Cottonwood Consultants Ltd. 1989. M.D. of Willow Creek Environmentally Significant Areas. Prepared for Alberta Forestry, Lands \& Wildlife; Edmonton. Vol. 1 (37pp) and Vol. 2 (41pp).

Cottonwood Consultants Ltd. 1991a. Lower Red Deer River Environmentally Significant Areas. Prepared for Alberta Forestry, Lands \& Wildlife; Edmonton. 66pp.

Cottonwood Consultants Ltd. 1991b. M.D. of Starland No. 47-- Environmentally Significant Areas. Prepared for Alberta Forestry, Lands \& Wildlife; Edmonton. 42pp.

Cottonwood Consultants Ltd. 1991c. Environmentally Significant Areas of the County of Newell. Prepared for Alberta Forestry, Lands \& Wildlife; Edmonton. 64pp.

Cottonwood Consultants Ltd. \& Pedocan Land Evaluation Ltd. 1991a. M.D. of Acadia No. 34 Environmentally Significant Areas. Prepared for Alberta Forestry, Lands \& Wildlife; Edmonton. Vol. 1 (72pp) and Vol. 2 (75pp).

Cottonwood Consultants Ltd. \& Pedocan Land Evaluation Ltd. 1991b. M.D. of Cypress No. 1 Environmentally Significant Areas. Prepared for Alberta Forestry, Lands \& Wildlife; Edmonton. 76pp. 
Cottonwood Consultants Ltd. \& Pedocan Land Evaluation Ltd. 1991c. M.D. of Kneehill No. 48 Environmentally Significant Areas. Prepared for Alberta Forestry, Lands \& Wildlife; Edmonton. Vol. 1 (72pp) and Vol. 2 (40pp).

Cottonwood Consultants Ltd. \& Pedocan Land Evaluation Ltd. 1991d. County of Forty Mile No. 8 Environmentally Significant Areas. Prepared for Alberta Forestry, Lands \& Wildlife; Edmonton. 22pp.

Coupland, R.T. 1973. A Theme Study of Natural Grasslands in Western Canada. A report to National and Historic Parks Branch, Canada Department of Indian Affairs and Northern Development.

Coupland, R.T and T.C. Brayshaw. 1953. The fescue grassland in Saskatchewan. Ecology 34: 386-405.

Court, G., S. Brechtel, G. Erickson and B Treichel. 1996. The future of the Peregrine Falcon (Falco peregrinus anatum) population in Alberta. In: Proceedings of the Fourth Prairie Conservation and Endangered Species Workshop. Edited by W.D. Willms and J.F. Dormaar. Provincial Museum of Alberta, Natural History Occasional Paper No. 23.

Courtney, R.F. 1986 (December). The effect of burning northern mixed prairie on pronghorn antelope range use. Master of Envir. Design Thesis; Univ. of Calgary; Calgary, Alberta.

Cox, K.W. 1993. Wetlands--a celebration of life. North American Wetlands Conservation Council (Canada). Issues Paper, No. 1993-1.

Creasey, R. 1997 (February). News release by the Prairie Conservation Forum. Release dated Wednesday, 5 February, 1997.

Crouch, G.L. 1978. Effects of protection from livestock grazing on a bottomland wildlife habitat in northeastern Colorado. In: Lowland river and stream habitat in Colorado: a symposium. p.118-125. Colo. Chap. Wildl. Soc. and Colo. Audubon Council.

Dale, B.C. 1993. Productivity of endemic grassland passerines in haylands. Pages 27-32 in: Holroyd, G.L., H.L. Dickson, M. Regnier, and H.C. Smith (eds.). Proc. of the 3rd Prairie Conserv. and Endang. Spec. Wkshp.; Nat. Hist. Occ. Paper No. 19. Provincial Museum of Alberta. Edmonton, AB.

Dauphine, C. 1996. Broadening the scope of recovery. Recovery-An Endangered Species Newsletter; Fall issue; Canadian Wildlife Service, Ottawa.

De Smet, K.D. and W.S. Miller. 1989. Status report on the Baird's sparrow (Ammodramus bairdii) in Canada. Prepared for the Committee on the Status of Endangered Wildlife in Canada. 26pp.

Desgranges, J.L. and P. Laporte. 1979. Second tour of inspection of Quebec heronries, 1978. Canadian Wildlife Service, Progress Note No. 105. 12pp. 
Diamond, J.M. 1976. Island biogeography and conservation: Strategy and limitations. Science 193:1027-1029.

Diamond, A.W., R.L. Schreiber and R. Bateman. 1989. Save the Birds. Breakwater Books, St. John's, NF., 384 pp.

Diamond, A.W. 1993. Integration of ecological and biodiversity concerns into sustainable land management. In: Proceedings of the International Workshop on Sustainable Land Management for the 21st Century (Volume 2: plenary papers). University of Lethbridge. Lethbridge, Canada. June 20-26, 1993.

Downes, C. 1995. Breeding Bird Survey. Wildlife watchers report, Environment Canada.

DU \& ENR. n.d. Proposal for a five-year co-operative waterfowl habitat program emphasizing key wetlands in Alberta. A joint proposal by Ducks Unlimited and Energy \& Natural Resources.

Duff, D.A. 1979. Riparian habitat recovery on Big Creek, Rich Country, Utah. P-91. In: Proceedings Forum-Grazing and Riparian/Stream Ecosystems. Trout Unlimited Inc.

Duxbury, A. and M.G. McKenna. 1990. On roadsides and wildlife. North Dakota Outdoors, March 1990.

Eagles, P.F.J. 1984. The Planning and Management of Environmentally Sensitive Areas. Longman, Harlow, U.K., 160 pp.

Easterly, T.G. and R.J. Guenzel. 1992. Responses of pronghorn to petroleum development on crucial winter range. Proceedings of the 15th Biennial Pronghorn Antelope Workshop; Rock Springs, Wyoming; June 8-11, 1992.

Edwards, Y. 1970. Man and the prairie landscape. Canadian Audubon 32:111-115.

Edwards, R.W. and F.M. Slater. 1981. Impact of road deaths on wildlife conservation. Nat. Wales 17:153-156.

Egler, F. 1977. The Nature of Vegetation: Its Management and Mismanagement. Aton Forest, Norfolk, CT.

Energy Resources Conservation Board (ERCB). 1994 (December 31). Designated Oil and Gas Fields, Oil Sands Deposits, Main Pipelines, Refineries and Gas Processing Plants. MAP ERCB-90, $($ Scale $=c a \cdot 1: 1,500,000)$. Calgary, AB

Environment Canada. 1986a. Canada's environment--an overview. Prepared by Environment Canada and Statistics Canada.

Environment Canada. 1986b. North American Waterfowl Management Plan. Canadian Wildlife Service Report. Ottawa. 37pp. 
Environment Canada. 1991. The state of Canada's environment--1991. Government of Canada. Ottawa.

Environment Canada. 1994 (December). Prairie Canada Waterfowl Population Surveys. Prepared by Environmental Conservation Branch, Canadian Wildlife Service, Winnipeg.

Environment Canada. 1995. Canadian biodiversity strategy--Canada's response to the Convention on Biological Diversity. Biodiversity Convention Office, Hull, Quebec. 80pp.

ERCB. 1992. Petroleum activity on native prairie--guidelines for surface disturbances. Prepared by Special Areas Board; Energy Resources Conservation Board; Alberta Environment; Alberta Forestry, Lands and Wildlife; and Alberta Energy.

Ehrlich, P. and A. Ehrlich. 1981. Extinction. The Causes and Consequences of the Disappearance of Species. Random House, New York, N.Y., 305 pp.

Ewel, J.J. 1987. Restoration is the ultimate test of ecological theory. In: W.R. Jordan III, M.E. Gilpin \& J.D. Aber (Eds), Restoration Ecology: A Synthetic Approach to Ecological Research, 31-33. Cambridge University Press, Cambridge.

Fairbarns, M. 1984 (January). Status report on Yucca glauca. Prepared for the Committee on the Status of Endangered Wildlife in Canada.

FEIS. 1996. Fire Effects Information System @http://www.fs.fed.us./database/feis/. USDA Forest Service Intermountain Research Station's Fire Science Laboratory, Missoula, Montana.

Finch, D.M. 1992. Threatened, endangered and vulnerable species of terrestrial vertebrates in the Rocky Mountain Region. U.S.D.A. Forest Service, Gen. Tech. Rep. RM-215; Rocky Mountain Forest and Range Experiment Station; Fort Collins, Colorado.

Finlay, C.J. 1996. Dear diary--what the journals of the fur traders tell us about a land we have lost. Environment Views 19(5):11-14.

Fisher, C.C., and W. Roberts. 1994. Herpetofaunal investigations on North American Waterfowl Management Plan properties in Alberta - 1994. 1) Aspen parkland grassland restoration. 2) Medicine Wheel Landscape. Alberta NAWMP Centre. NAWMP-010. Edmonton, Alberta. 23pp.

Fleharty, E.D. and K.W. Navo. 1983. Irrigated cornfields as habitat for small mammals in the sandsage prairie region of western Kansas. J. Mammal. 64:367-379.

Fleischner, T.L. 1994. Ecological costs of livestock grazing in western North America. Conserv. Biol. 8(3):629-644.

Forsyth, A. 1983. The end of emptiness. Equinox 11:66-78. 
Fritts, S.H., E.E. Bangs, J.A. Fontaine, W.G. Brewster and J.F. Gore. 1995. Restoring wolves to the northern Rocky Mountains of the United States. In. Carbyn, L.N., S.H. Fritts and D.R. Seip. 1995. Ecology and conservation of wolves in a changing world. Canadian Circumpolar Institute. Occas. Publication No. 35., pp107-125.

Gainer, R.S. 1995. Recent winter biology of pronghorn near Hanna, Alberta. Alberta Naturalist Vol. 25(4):66-69.

Gainer, R.S. and E. Hofman. 1996. Additional characteristics of the winter biology of pronghorns near Hanna, Alberta. Alberta Naturalist Vol. 26(3):66-69.

Geist, V. 1996. Buffalo Nation-History and Legend of the North American Bison. Fifth House Publishers; Saskatoon, Saskatchewan and Calgary, Alberta.

Geowest Environmental Consultants Ltd. 1996. Environmentally Significant Areas Inventory: Grassland and Parkland Natural Regions, Alberta. Prepared for Alberta Environmental Protection. $121 \mathrm{pp}+$ appendices.

Gillen, R.L., W.C. Krueger, and R.F. Miller. 1984. Cattle distribution on mountain rangeland in northeastern Oregon. J. Range Manage. 37:549-553.

Godfrey, W.E. 1986. The Birds of Canada. Revised edition. National Museum of Natural Sciences, National Museums of Canada, Ottawa, Canada.

Gollop, J.B. 1978. Changes in songbird populations since the mid-1940s in the prairie provinces. Pp. 78-103. In: Davies, W.A. (ed.). Nature and change on the Canadian plains. Can. Plains Proceedings 6; Can. Plains Res. Centre; Univ. Regina; Regina, Saskatchewan.

Goossen, J.P., S. Brechtel, K.D. De Smet, D. Hjertaas and C. Wershler. 1993. Canadian Baird's sparrow recovery plan. Recovery of Nationally Endangered Wildlife Report No. 3. Ottawa: Canadian Wildlife Federation. 28pp.

Goossen, P. and B. Dale. 1996. Delisting not yet a conservation victory. Recovery-An Endangered Species Newsletter; Fall issue; Canadian Wildlife Service, Ottawa.

Government of Alberta. 1995 (March). Special Places 2000: Alberta's Natural Heritage. Policy and Implementation Plan.

Grilz, P.L. and J.T. Romo. 1995. Management considerations for controlling smooth brome in fescue prairie. Natural Areas Journal 15(2):148-156.

Grumbine, R.E. 1992. Ghost Bears. Exploring the Biodiversity Crisis. Island Press, Washington, D.C., 294 pp.

Gummer, D. 1995. Recently listed Kangaroo Rat is focus of new research. In. "The Suffield Rattler"--the official newsletter of the Canadian Forces Base Suffield National Wildlife Area. Published by the Canadian Wildlife Service. 
Hamilton, K.G.A. 1995 (June). Correspondence to J. Gould and D. Nernberg. Biological Resources Division, Agriculture Canada.

Hanley, P. T., J. E. Hemming, J.W. Morsell, T.A. Morehouse, L.E. Leask and G.S. Harrison. (n.d.). Natural resource protection and petroleum development in Alaska. Report prepared for Office of Biological Services, Fish and Wildlife Service. U.S. Department of the Interior, Washington, DC. $318 \mathrm{pp}$.

Hardy, RM. \& Associates Ltd. 1975. Preliminary report on effects of pipeline construction on grasslands of southern Alberta. Prepared for the Research Secretariat of Alberta Department of the Environment.

Heitschmidt, R.K. 1990 (April). The role of livestock and other herbivores in improving rangeland vegetation. Rangelands 12(2):112-115.

Herkert, J. R. 1994. The effects of habitat fragmentation on midwestern grassland bird communities. Ecological Applications 4(3):461-471.

Heyer, R. 1996 (April). Vanishing amphibians: a real problem? World Conservation, pp1011. Published by IUCN, The World Conservation Union.

Hicks, R. 1994. Moving to sustainable agriculture. In. Proceedings of the 1994 Soil Conservation Workshop and Alberta Conservation Tillage Society. 16th Annual Meeting, Edmonton, Alberta.

Hjertaas, D. 1996. Status of Burrowing Owl and of recovery efforts in Canada. In: Proceedings of the Fourth Prairie Conservation and Endangered Species Workshop. Edited by W.D. Willms and J.F. Dormaar. Provincial Museum of Alberta, Natural History Occasional Paper No. 23.

Hjertaas, D., S. Brechtel, R. Jones, R. Edwards and C. Schroeder. 1993. National recovery plan for the greater prairie chicken. Report No. 5. Ottawa: Recovery of Nationally Endangered Wildlife Committee, 18pp.

Hjertaas, D., S. Brechtel, K. De Smet, O. Dyer, E. Haug, G. Holroyd, P. James and J. Schmutz. 1995. National recovery plan for the burrowing owl. Report No. 13. Ottawa: Recovery of Nationally Endangered Wildlife Committee, 33pp.

Hoage, R.J. (editor). 1985. Animal Extinctions. What Everyone Should Know. Smithsonian Institution Press, Washington, D.C., 192 pp.

Hobbs, R.J. and L.F. Huenneke. 1992. Disturbance, diversity, and invasion: implications for conservation. Conserv. Biol. 6(3):324-337.

Holroyd, G.L., H.L. Dickson, M. Regnier and H.C. Smith. 1993. Proceedings of the third prairies conservation and endangered species workshop. Natural History Occasional Paper No. 19. Provincial Museum of Alberta. Edmonton. 
Holroyd, G.L. 1996. Personal Communication. Canadian Wildlife Service, Edmonton.

Horejsi, B.L. 1995. Habitat Fragmentation by the Oil and Gas Industry in Alberta and British Columbia: Its Impact on Wildlife. Western Wildlife Environments Consulting Ltd., Calgary, AB., 10 pp.

Howe, M.A. 1987. Wetlands and waterbird conservation. Amer. Birds 41:204-209.

Howe, M.A., P.H. Geissler and B.A. Harrington. 1989. Population trends of North American shorebirds based on the International Shorebird Survey. Biol. Conserv. 49:185-199.

Hummel, M. (editor). 1989. Endangered Spaces. The Future for Canada's Wilderness. Key Porter Books, Toronto, ON. 288 pp.

Hummel, M. (editor). 1995. Protecting Canada's Endangered Spaces. An Owner's Manual. Key Porter Books, Toronto, ON., 251 pp.

Hynes, H.B.N. 1970. The ecology of running waters. University of Toronto Press. 555pp.

Ignatiuk, J. and D.C. Duncan. 1995 (September). Wetland loss in Aspen Parkland of Saskatchewan. Blue Jay 53(3):129-133.

IISD. 1994. Sustainability of Canada's Agri-Food system-a prairie perspective. Published by the International Institute for Sustainable Development (IISD) for the Faculty of Agricultural and Food Sciences, University of Manitoba.

James, P.C. 1993. Habitat fragmentation and burrowing owls in Saskatchewan. In. Proceedings of the Third Prairie Conservation and Endangered Species Workshop. Provincial Museum of Alberta Nat. Hist. Occas. Paper No. 19., pp.193-194.

Jennersten, O. 1988. Pollination in Dianthus deltoides (Caryophyllaceae): effects of habitat fragmentation on visitation and seed set. Conservation Biology 2:359-366.

Johns, B., E. Telfer, M. Cadman, D. Bird, R. Bjorge, K. De Smet, W. Harris, D. Hjertaas, P. Laporte and R. Pittaway. 1994. National recovery plan for the loggerhead shrike. Report No. 7. Ottawa: Recovery of Nationally Endangered Wildlife Committee, 32pp.

Johnston, A. and S. Smoliak. 1976 (September). Settlements of the grasslands and the Greater Prairie Chicken. Blue Jay 34(3):153-156.

Kavanagh, K., T. Iacobelli and S. Rowe. 1994. A Protected Areas Gap Analysis Methodology: Planning for the Conservation of Biodiversity. World Wildlife Fund Canada, Toronto, ON. $68 \mathrm{pp}$.

Kavanagh, K., R. Noss and T. Iacobelli. 1995. Building the Ark: the Science Behind the Selection of Protected Areas. Pp. 2-8, in: Hummel, M. (editor). Protecting Canada's Endangered Spaces. An Owner's Manual. Key Porter Books, Toronto, ON., 251 pp. 
Kerr, D.S., L.J. Morrison and K.E. Wilkinson. 1993. Reclamation of native grasslands in Alberta: A review of the literature. Alberta Land Conservation and Reclamation Council Report No. RRTAC 93-1. Edmonton.

Kindschy, R., C. Sundstrom and J. Yoakum. 1978. Range/wildlife interrelationships pronghorn. In: Proceedings of the Eighth Biennial Pronghorn Antelope Workshop. Alberta Recreation, Parks and Wildlife, Edmonton, Alberta. pp. 216-269.

Kirkpatrick, J.B., and M.J. Brown. 1994. A comparison of direct and environmental domain approaches to planning reservation of forest higher plant communities and species in Tasmania. Conservation Biology 8:217-224.

Klausz, E.E., R.W. Wein and L.N. Carbyn. 1996. Interaction of vegetation structure and snow conditions on prey availability for Swift Fox in the northern mixed-grass prairies: some hypotheses. In: Proceedings of the Fourth Prairie Conservation and Endangered Species Workshop. Edited by W.D. Willms and J.F. Dormaar. Provincial Museum of Alberta, Natural History Occasional Paper No. 23.

Lamb, D. 1988. IUCN guidelines for restoration of degraded ecosystems. Draft, IUCN, Gland.

Lamoureux, R.J., G.G. Chow and B.O.K. Reeves. 1983. Environmentally Significant Areas of the Calgary Region. Prepared for the Calgary Regional Planning Commission. 257pp.

Land Information Services. 1994. Natural Regions and Subregions of Alberta. Map produced by Alberta Environmental Protection. Edmonton, Alberta.

Lassuy, D.R. 1995. Introduced species as a factor in extinction and management of native fish species. Amer. Fisheries Soc. Symposium 15:391-396.

Laursen, K. 1981. Birds on roadside verges and the effect of mowing on frequency and distribution. Biol. Conserv. 20:81-96.

Leftwich, T.J. and C.D. Simpson. 1978. The impact of domestic livestock and farming on Texas pronghorn. In: Proceedings of the Eighth Biennial Pronghorn Antelope Workshop. Alberta Recreation, Parks and Wildlife, Edmonton, Alberta. pp.307 - 320.

Leopold, A. 1953. Round River. Oxford University Press, New York. 173pp.

Lewis, K.T. 1993. Gap Analysis Workbook for Regional Protected Areas Teams. (Working Draft - June 1993). A Protected Areas Strategy for British Columbia. Province of British Columbia, Victoria, B.C., 43 pp. + 14 Appendices.

Lyon, L.J. 1983. Road density models describing habitat effectiveness for elk. J. Forestry 81(9):592-595. 
Mader, H.J. 1984. Animal habitat isolation by roads and agricultural fields. Biol. Conserv. 20:59-68.

Mandaville, S.M. 1996. Soil \& Water Conservation Society of Metro Halifax. Website address: http://www.ccn.cs.dal.ca/Science/SWCS/SWCSEutrophication.html.

Margules, C.R. and G.A. Milkovits. 1994. Contrasting effects of habitat fragmentation on the scorpion, Cercophonius squama, and an amphipod. Ecology 75(7):2033-2042.

McNicholl, M.K. 1988. Ecological and human influences on Canadian populations of grassland birds. In. Ecology and Conservation of Grassland Birds; ICBP Technical Publication No. 7.

Mech, L.D. 1995. What do we know about wolves and what more do we need to learn? In. Carbyn, L.N., S.H. Fritts and D.R. Seip. 1995. Ecology and conservation of wolves in a changing world. Canadian Circumpolar Institute. Occas. Publication No. 35., pp537-545.

Meehan, W.R. and W.S. Platts. 1978. Livestock grazing and the aquatic environment. J. Soil and Water Conserv. 33(6):274-278.

Microsoft Internet Explorer. 1996. Endangered species. Internet addresses are: (1) http://www-nais.ccm.emr.ca/schoolnet/issues/risk/birds/ebirds.html; (2) http://www.afternet.com/ teal/shawk.html

Mills, G.S., J.B. Dunning Jr. and J.M. Bates. 1989. Effects of urbanization on breeding bird community structure in southwestern desert habitats. Condor 91:416-428.

Mills, L.S. 1995. Edge effects and isolation: Red-backed voles on forest remnants. Conservation Biology 9(2):395-403.

Mitchell, G.J. 1980. The Pronghorn Antelope in Alberta. Dept. of Biol., University of Regina; Regina, Sask., 165pp.

Monds, S. 1995. Basic principles--planning for species needs within a landscape planning framework. Environment Canada.

Myers, N. 1993. Biodiversity and the Precautionary Principle. Ambio 22(2-3):74-79.

Naeem, S., L.J. Thompson, S.P. Lawler, J.H. Lawton and R.M. Woodfin. 1994. Declining biodiversity can alter the performance of ecosystems. Nature 368(6473):734-737.

Nagy, J.A. and J.R. Gunson. 1990. Management plan for grizzlies in Alberta. Wildlife Management Planning Series No. 2. Alberta Forestry, Lands and Wildlife; Fish and Wildlife Division.

National Energy Board. 1996 (May). Express Pipeline Project--Report of the Joint Review Panel. Prepared by the NEB and the Canadian Environmental Assessment Agency. 197pp. 
Nature Canada. 1996 (Summer). Extinction is forever. Advertisement placed by the Canadian Nature Federation.

NAWMP. 1996. North American Waterfowl Management Plan. 1986 to 1996: 10th Anniversary Report-Canada. 16pp. Prepared by NAWMP and its Partners.

Nebraska Game \& Parks Commission. 1995. Nebraska Wildlife - Prairie Dogs. Wildlife Note prepared by the Nebraska Game \& Parks Commission.

Nelson, J.W. 1989. The duck depression of the 1980s: an agenda for recovery. A Ducks Unlimited Discussion Paper. Ducks Unlimited, Inc.

Nelson, J.G. 1993. Beyond Parks and Protected Areas. From public lands and private stewardship to landscape planning and management. Pp. 45-56, In: Dearden, P., and Rollins, R. (editors). Parks and Protected Areas in Canada. Planning and Management. Oxford University Press, Toronto, ON. 336 pp.

Nelson, J.S. and M.J. Paetz. 1992. The Fishes of Alberta. 2nd edition. University of Alberta Press and the University of Calgary Press. $437 \mathrm{pp}$.

Nietfeld, M., J. Wilk, K. Woolnough and B. Hoskin. 1985. Wildlife habitat requirement summaries for selected wildlife species in Alberta. Alberta Forestry, Lands and Wildlife. Fish and Wildlife Division.

Norton, B.G. 1987. Why Preserve Natural Variety? Princeton University Press, Princeton, N.J., $281 \mathrm{pp}$.

Noss, R.F. 1995. Maintaining Ecological Integrity in Representative Reserve Networks. Discussion Paper. World Wildlife Fund Canada/WWF-U.S., Toronto, ON./Washington, D.C., $77 \mathrm{pp}$.

Noss, R.F., and A.Y. Cooperrider. 1994. Saving Nature's Legacy. Protecting and Restoring Biodiversity. Island Press, Washington, D.C., 416 pp.

NPSC. 1996. Northern Prairie Science Centre@http://www.npsc.nbs.gov. National Biological Service, U.S. Department of the Interior.

Ockenfels, R.A., C.L. Ticer, A. Alexander and J.A. Wennerlund. 1996. A landscape-level Pronghorn habitat evaluation model for Arizona. Ariz. Game and Fish Dep. Tech. Rep. 19, Phoenix. 50pp.

O'Leary, D. and D. Downing. 1990. Eastern Irrigation District: an analysis of wetland habitat change. Volume 1. Alberta Forestry, Lands and Wildlife. 30pp.

Ostlie, W.R., R.E. Schneider, J.M. Aldrich, T.M. Faust, R.L.B. McKim and H.M. Watson. 1996. The status of biodiversity in the Great Plains. The Nature Conservancy, 1815 North Lynn Street, Arlington, VA. USA. 
Owens, R.A. and M.T. Myres. 1973. Effects of agriculture upon populations of native passerine birds of an Alberta fescue grassland. Can. J. Zool. 51:697-713.

Paine, L., D.J. Undersander, D.W. Sample, G.A. Bartelt and T.A. Schatteman. 1996 (July). Cattle trampling of simulated ground nests in rotationally grazed pastures. J. Range Mgmt. 49(4):294-300.

Paquet, P. and A. Hackman. 1995 (May). Large carnivore conservation in the Rocky Mountains: a long-term strategy for maintaining free-ranging and self-sustaining populations of carnivores. World Wildlife Fund Canada. 52pp.

Partners in flight - Canada. 1996. Framework for landbird conservation in Canada. Canadian landbird Conservation Working Group. Hull, Quebec. 23pp.

Patriquin, D.L. 1993. An overview of priority vertebrate species and habitats in relation to NAWMP Program Delivery in Alberta. D.A. Westworth and Associates Ltd. Alberta NAWMP Centre. NAWMP-006. Edmonton, Alberta. 77pp.

Peles, J.D. and G.W. Barrett. 1996. Effects of vegetative cover on the population dynamics of meadow voles. Journal of Mammalogy 77(3):857-869.

PFRA. 1989. Prairie soils: the case for conservation. Prepared by Soil and Water Conservation Service. Prairie Farm Rehabilitation Administration, Agriculture Canada.

PHJV. 1991. Prairie Habitat Joint Venture 1992 Program. Prepared by its Canadian Partners-Environment Canada; Agriculture Canada; Governments of Alberta, Saskatchewan and Manitoba; Ducks Unlimited Canada; North American Wildlife Foundation and Wildlife Habitat Canada.

PHJV. 1993 (December). PHJV Progress Summary. Prepared by Prairie Habitat Joint Venture (PHJV), a Key Target Area of the North American Waterfowl Management Plan.

PHJV. 1995. Prairie Habitat Joint Venture: Conserving an International Resource, 19861994. Prepared under the auspices of the North American Waterfowl Management Plan.

Platts, W.S. 1981. Influence of forest and rangeland management on anadromous fish habitat in western North America-effects of livestock grazing. U.S. Department of Agriculture. Pacific Northwest Forest and Range Experiment Station. General Technical Report PNW124.

Poston, B., D.M. Ealey, P.S. Taylor and G.B. McKeating. 1990. Priority migratory bird habitats of Canada's Prairie Provinces. Canadian Wildlife Service. Environment Canada. $107 \mathrm{pp}$. 
Powell, G.L. and A.P. Russell. 1996. Alberta's amphibians and reptiles: current research and conservation issues. In: Proceedings of the Fourth Prairie Conservation and Endangered Species Workshop. Edited by W.D. Willms and J.F. Dormaar. Provincial Museum of Alberta, Natural History Occasional Paper No. 23.

Prairie Conservation Forum. 1996 (May). 1994-1995 Annual Report. Alberta Environmental Protection.

Prairie Conservation Forum. 1997 (January). Alberta Prairie Conservation Action Plan. Published by the Prairie Conservation Forum, Lethbridge, Alberta. 27pp.

PrairiNet Webmaster. 1996. The National Grasslands System. A note from the prairiNet webmaster. $5 \mathrm{pp}$

Prescott, D.R.C., R. Arbuckle, B. Goddard and A. Murphy. 1993. Methods for the monitoring and assessment of avian communities on NAWMP landscapes in Alberta, and 1993 results. Produced by Alberta NAWMP Centre, Edmonton.

Prescott, D.R.C., A.J. Murphy and E. Ewaschuk. 1994. An avian community approach to determining biodiversity values of NAWMP habitats in the aspen parkland of Alberta. Alberta North American Waterfowl Management Plan Centre, Edmonton, Alberta.

Prescott, D.R.C. and A.J. Murphy. 1996. Habitat associations of grassland birds on native and tame pastures in the Aspen Parkland of Alberta. Alberta NAWMP Centre. NAWMP-021. Edmonton, Alberta. $36 \mathrm{pp}$.

Prescott, D.R.C. and G.M. Wagner. 1996. Avian responses to implementation of a complementary/rotational grazing system by the North American Waterfowl Management Plan in southern Alberta: the Medicine Wheel Project. Alberta NAWMP Centre. NAWMP018. Edmonton, AB. 24pp.

Rasmussen, K. 1969. The target for 1980. Proceedings of the Canadian Forage Crops Symposium. Western Cooperative Fertilizers Limited, Calgary, Alberta.

Reed, R.A., J. Johnson-Barnard and W.L. Baker. 1996. Contribution of roads to forest fragmentation in the Rocky Mountains. Conserv. Biol. 10(4):1098-1106.

RENEW. 1996. Fifth Annual Report: 1994/95. Recovery of Nationally Endangered Wildlife Secretariat, Canadian Wildlife Service. 35pp.

Ricklefs, R.E. 1979. Ecology. Chiron Press, New York, New York.

Roberts, W. 1989. The sculpins of Alberta. Alberta Naturalist 18(4):121-127.

Roberts, W. 1992. Declines in amphibian populations in Alberta. In: Declines in Canadian amphibian populations: designing a national monitoring strategy. Occ. Pap. No. 76. Canadian Wildlife Service, Environment Canada, Ottawa. 120pp. 
Rood, S.B. and J.M. Mahoney. 1990. Collapse of riparian poplar forest downstream from dams in western prairies: probable causes and prospects for mitigation. Environ. Mgmt. 4(4):451-454.

Rosaasen, K.A. and J.S. Lokken. 1993. Canadian agricultural policies and other initiatives and their impacts on prairie agriculture. In: Proceedings of the International Workshop on Sustainable Land Management for the 21st Century (Volume 2: plenary papers). University of Lethbridge. Lethbridge, Canada. June 20-26, 1993.

Rosenstock, S.S. 1996. Shrub-grassland small mammal and vegetation responses to rest from grazing. J. Range Mgmt. 49(3):199-203.

Russell, A.P. and A.M. Bauer. 1993. The amphibians and reptiles of Alberta. University of Calgary Press \& University of Alberta Press. 264pp.

Salt, W.R. and J.R. Salt. 1976. The birds of Alberta. Hurtig Publishers. Edmonton.

Samson, F. and F. Knopf. 1994. Prairie conservation in North America. BioScience 44(6):418-421.

Sanderson, K. 1983. Wildlife roadkills and potential mitigation in Alberta. ECA83-ST/1. Edmonton: Environment Council of Alberta. 10 pages.

Saskatchewan Research Council. 1995 (spring). Do farming practices affect water quality? In Prairie Water News 5(1):1-2.

Sauer, J. R., B. G. Peterjohn, S. Schwartz and J. E. Hines. 1996. The North American Breeding Bird Survey. Patuxent Wildlife Research Center, Laurel, MD. Website address: http://www.mbr.nbs.gov:80/bbs/bbs.html.

Schmitt, K. 1980. Wetland reconnaissance within the South Saskatchewan River Basin. Unpublished report prepared for Ducks Unlimited Canada. 29pp.

Schmutz, J.K. 1987. The effect of agriculture on Ferruginous and Swainson's hawks. J. Range Mgmt. 40(5):438-440.

Schmutz, J.K. 1990. Management plan for the ferruginous hawk in Alberta. World Wildlife Fund Canada and Alberta Fish and Wildlife Division. Unpublished report. 69pp.

Schmutz, J.K., S.H. Brechtel, K.D. De Smet, D.G. Hjertaas, C.S. Houston and G.L. Holroyd. 1994. National recovery plan for the ferruginous hawk. Report No. 11. Ottawa: Recovery of Nationally Endangered Wildlife Committee, 35pp.

Schramm, P. 1990. Prairie restoration: a 25-year perspective on establishment and management. Pages 169-177 in Proceedings of the Twelfth North American Prairie Conference. Cedar Falls, Iowa. 
Schreckenberg, K., M. Hadley and M.I. Dyer (eds.). 1990. Management and restoration of human-impacted resources: approaches to ecosystem rehabilitation. MAB Digest 5 , UNESCO, Paris.

Scobie, D. 1994. Annual Report of the Operation Grassland Community. Prepared for the Alberta Fish and Game Association. 11pp.

Semenchuk, G.P. (ed.) 1992. The Atlas of Breeding Birds of Alberta. Published by the Federation of Alberta Naturalists.

Shandruk, L. 1987. A review of habitat requirements and management priorities for the Canadian breeding population of Trumpeter Swans. In: Holroyd, G.L., W.B. McGillivray, P.H.R. Stepney, D.M. Ealey, G.C. Trottier and K.E. Eberhart. (eds.). Proceedings of the Workshop on Endangered Species in the Prairie Provinces. Occas. Paper No. 9, Provincial Museum of Alberta, Natural History. 367pp.

Shank, C. 1996. Pigeonholing nature: the problem of peripheral species. Recovery-An Endangered Species Newsletter; Fall issue; Canadian Wildlife Service, Ottawa.

Shetsen, I. 1987. Quaternary Geology, Southern Alberta. 1:500,000 scale. Terrain Sciences Dept., Alberta Research Council.

Shields, J.A. and J.D. Lindsay. 1990. Soil Landscapes of Canada--Alberta. Digital Map Data; Scale 1:1,000,000; CanSIS No. AL088200, version 91.11.30; CLBRR Archive, Agriculture Canada, Research Branch, Ottawa, Canada. (CLBRR Contribution No. 91-105D).

Sinclair, A.R.E., D.S. Hik, O.J. Schmitz, G.G.E. Scudder, D.H. Turpin and N.C. Larter. 1995. Biodiversity and the need for habitat renewal. Ecological Applications 5(3):579-587.

Skibicki, A.J. 1995. Preliminary boundary analysis of the Greater Pukaskwa National Park Ecosystem using the $A B C$ resource survey approach. Occasional Paper No. 6., Dept. of Canadian Heritage, Parks Canada.

Skinner, D.L., S. Johnston and D.A. Westworth. 1996. Abundance and distribution of mammals on a complementary/rotational grazing system in southern Alberta. Alberta NAWMP Centre. NAWMP-023. Edmonton, Alberta. 24 pp.

Slocombe, D.S. 1993. Implementing ecosystem-based management. BioScience 43(9):612622.

Smiley, J. 1994 (March/April). So shall we reap. Sierra, p74.

Smith, B. 1991. Status report on slender mouse-ear cress. Prepared for the Committee on the Status of Endangered Wildlife in Canada.

Smith, H.C. 1993. Alberta mammals--an atlas and guide. Provincial Museum of Alberta, Edmonton, Alberta. 
Smith, B. 1994. Status report on the hare-footed locoweed. Prepared for the Committee on the Status of Endangered Wildlife in Canada.

Smith, B. and C. Bradley. 1990a. Status report on sand verbena. Prepared for the Committee on the Status of Endangered Wildlife in Canada.

Smith, B. and C. Bradley. 1990b. Status report on western spiderwort. Prepared for the Committee on the Status of Endangered Wildlife in Canada.

Smith, B. and C. Bradley. 1990c. Status report on smooth goosefoot. Prepared for the Committee on the Status of Endangered Wildlife in Canada.

Soil Landscapes of Canada-Alberta. 1986. 1:1,000,000 scale map. Compiled by J.A. Shields, Centre for Land and Biological Resources Research, Research Branch, Agriculture Canada, Ottawa and J.D. Lindsay, under contract.

Soper, J.D. 1964. The Mammals of Alberta. Queen's Printer, Edmonton.

South Country Protected Areas Project. 1993. Phase One Summary Report. Prepared by Coaldale Ecology Club, Lethbridge Naturalists Society, South Country Community Association and the Southern Alberta Environmental Group.

Statistics Canada. 1992. 1991 census of agriculture. Ottawa.

Statistics Canada. 1994. Human activity and the environment. Ministry of Industry, Science and Technology, Ottawa, Ontario.

Stelfox, J.B. (editor). 1995. Relationships between stand age, stand structure, and biodiversity in aspen mixedwood forests in Alberta. Jointly published by Alberta Environmental Centre (AECV95-R1), Vegreville, AB., and Canadian Forest Service (Project No. 0001A), Edmonton, AB., 308 pp.

Strong, W.L. and K.R. Leggat. 1992. Ecoregions of Alberta. Land Information Services Division, Alberta Forestry, Lands and Wildlife. 59pp.

Strong, W.L., B.K. Calverley, A.J. Richard and G.R. Stewart. 1993 (June). Characterization of wetlands in the settled areas of Alberta. Prepared by Ecological Land Surveys Ltd. and Ducks Unlimited Canada.

Sweetgrass Consultants Ltd. 1988. Environmentally Significant Areas of the Counties of Lacombe and Stettler. Prepared for Alberta Forestry, Lands \& Wildlife; Edmonton. 33pp.

Sweetgrass Consultants Ltd. 1989. Environmentally Significant Areas of the County of Paintearth. Prepared for the Red Deer Regional Planning Commission and Alberta Forestry, Lands \& Wildlife; Edmonton. 25pp. + maps. 
Sweetgrass Consultants Ltd. 1991. Environmentally Significant Areas of the County of Mountain View. Prepared for Alberta Forestry, Lands \& Wildlife; Edmonton. 27pp.

Taylor, P.D., Fahrig, L., K. Henein and G. Merriam. 1993. Connectivity is a vital element of landscape structure. Oikos 68(3):571-573.

Thorpe, J. and R. Godwin. 1992. Regional vegetation management plan for Douglas Provincial Park and Elbow PFRA Pasture. Plant Ecology Section, Saskatchewan Research Council, SRC Publ. No. E-2520-1-E-92.

Tilman, D., R.M. May, C.L. Lehman and M.A. Nowak. 1994. Habitat destruction and the extinction debt. Nature 371(6492):65-66.

Trant, D., C. De Boer and K.Van Tighem. 1995. Environmental change around Waterton Lakes National Park. In. Environmental Perspectives--Studies and Statistics. National Accounts and Environmental Division, Statistics Canada.

Trottier, G.C. 1992. Conservation of the Canadian Prairie Grasslands: A Landowner's Guide. Canadian Wildlife Service. Environment Canada.

Tubbs, A.A. 1980. Riparian bird communities of the Great Plains. In. Management of Western Forests and Grasslands for Nongame Birds--workshop proceedings; Feb. 11-14, 1980; Salt Lake City, Utah. USDA For. Serv. Gen. Tech. Rep. INT-86.

Turner, B.C., G.S. Hochbaum, F.D. Caswell and D.J. Nieman. 1987. Agricultural impacts on wetland habitats on the Canadian prairies, 1981-85. Transactions of the 52nd North American Wildlife and Natural Resources Conference, pp. 206-215.

Turner, B.C. and F.D. Caswell. 1989. Waterfowl population and habitat status. Ducks Unlimited Sixth International Waterfowl Symposium. Washington, D.C. pp 12-26.

Turner, B. and P. Pryor. 1992 (June). Alberta Waterfowl Status Report. Canadian Wildlife Service.

United States Department of Agriculture (USDA). 1993. Eastside Forest Ecosystem Health Assessment. Vol. 1: Executive Summary. USDA, National Forest System, Forest Service Research, $57 \mathrm{pp}$.

United States Forest Service (USFS). 1990. Open Road Density Standards. Draft EIS. Amendment No. 10 to the Flathead National Forest Land and Resource Management Plan. Flathead National Forest, Kalispell, MT.

Usher, R. and J. Scarth. 1990. Alberta's wetlands: water in the bank. Published by Environment Council of Alberta. 37pp.

Van Tighem, K. 1989. Clots in nature's lifeblood. Borealis 1(2):35-41. 
Van Tighem, K. 1996. From wilds to weeds--Alberta's changing ecosystems. Environment Views 19(5):5-8.

Van Vuren, D. 1982. Comparative ecology of bison and cattle in the Henry Mountains, Utah. Pp 449-457 in L. Nelson, J.M. Peek and P.D. Dalke, editors. Proceedings of the wildlifelivestock relationships symposium. Forest, Wildlife and Range Experiment Station, University of Idaho, Moscow, Idaho.

van Zyll de Jong, C.G. 1983. Handbook of Canadian Mammals. National Museums of Canada, Ottawa, Canada.

Vickery, V.R. and D.K. McE. Kevan. 1985. The insects and arachnids of Canada--Part 14. The grasshoppers, crickets, and related insects of Canada and adjacent regions. Research Branch, Agriculture Canada; Ottawa, Ontario. Publication 1777. 918pp.

Vitousek, P.M., C.M. D'antonio, L.L. Loope and R. Westbrooks. 1996 (Sept-Oct). Biological invasions as global environmental change. Amer. Scientist 84:468-478.

Wallis, C. 1987. Critical, threatened and endangered habitats in Alberta. Provincial Museum of Alberta, Occas. Paper No. 9:49-63.

Wallis, C. 1988. The unsung benefits of wind erosion--stabilizing sand dunes spell trouble for rare plants. Iris Newsletter 3:1-2.

Wallis, C. 1989. Western blue flag--management plan. Prepared for World Wildlife Fund Canada, Prairie for Tomorrow. 37pp.

Wallis, C. and C. Wershler. 1988 (March). Rare wildlife and plant conservation studies in sandhill and sand plain habitats of southern Alberta. Alberta Forestry, Lands and Wildlife; Alberta Recreation and Parks; World Wildlife Fund Canada.

Warren, C.L., A. Kerr and A.M. Turner. 1989. A state of the environment fact sheet-urbanization of rural land in Canada, 1981-86. Environment Canada, Ottawa.

Webb, N.R. 1988. Studies on the invertebrate fauna of fragmented heathland in Dorset, U.K. and implications fro conservation. Biological Conservation 47:153-165.

Weins, T.W. 1996. Sustaining Canada's wildlife habitat. Draft report, Prairie Farm Rehabilitation Administration, Regina.

Wells, M.P. and K.E. Brandon. 1993. The principles and practice of buffer zones and local participation in biodiversity conservation. Ambio 22(2-3):157-162.

Wershler, C. 1987. The Mountain Plover in Canada. Pp. 259-261. In: Holroyd, G.L., W.B. McGillivray, P.H.R. Stepney, D.M. Ealey, G.C. Trottier and K.E. Eberhart. (eds.). Proceedings of the Workshop on Endangered Species in the Prairie Provinces. Occas. Paper No. 9, Provincial Museum of Alberta, Natural History. 367pp. 
Wershler, C. 1990. Status of the Baird's sparrow in Alberta--1989. Prepared by Sweetgrass Consultants Ltd. for World Wildlife Fund, Canadian Wildlife Service and Alberta Fish and Wildlife Division.

Wershler, C. 1993. Grazing and grassland birds. Pages 34-36 in: Holroyd, G.L., H.L. Dickson, M. Regnier, and H.C. Smith (eds). Proc. of the 3rd Prairie Conserv. and Endang. Species Workshop. Nat. Hist. Occ. Paper No. 19. Provincial Museum of Alberta. Edmonton, AB.

Wershler, C. and C. Wallis. 1986. Lost River Significant Features Assessment. Alberta Forestry, Lands and Wildlife; Public Lands Division.

Wershler, C. and C. Wallis. 1990 (February). Survey and evaluation of northern fescue grassland in Alberta-1989. Alberta Forestry, Lands and Wildlife, Edmonton. 37pp.

Westworth, D.A. \& Associates. 1993a. Terrestrial resources impact assessment--Pine Coulee Reservoir. Prepared by D.A. Westworth \& Associates; Edmonton, Alberta.

Westworth, D.A. \& Associates. 1993b. Functions and values of Alberta's wetlands. Prepared for Wetlands Management Steering Committee; Edmonton, Alberta. 95pp.

Wetlands for the Americas. n.d. Shorebirds and agriculture. Brochure prepared by Wetlands for the Americas, National Fish and Wildlife Foundation and the North American Waterfowl Management Plan.

Wickett, R.G., P.D. Lewis, A. Woodliffe and P. Pratt. 1992. Spirit of the Land, Our Prairie Legacy. Proceedings of the Thirteenth North American Prairie Conference, August 6-9, 1992, Windsor, Ontario. Department of Parks and Recreation; Windsor, Ontario.

Wilcox, B.A. and D.D. Murphy. 1985. Conservation strategy: the effects of fragmentation on extinction. Amer. Naturalist 125:879-887.

Willard, D.E. 1978. The impact of transmission lines on birds. In: Avery, M.L., ed. Impacts of transmission lines on birds in flight. Proceedings of a workshop, Oak Ridge Associated Universities; 1978 January 31-February 2; Oak Ridge, TN. FWS/OBS 78/48. Washington, DC: U.S. Dept. of the Interior, Fish \& Wildlife Service, Office of Biol. Services; 1978:3-7.

Willms, W.D., S. Smoliak and J.F. Dormaar. 1985. Effects of stocking rate on a rough fescue grassland vegetation. J. Range Mgmt. 38:220-225.

Willms, W.D. and J.F. Dormaar (editors). 1996. Proceedings of the Fourth Prairie Conservation and Endangered Species Workshop. Provincial Museum of Alberta, Natural History Occasional Paper No. 23.

Willoughby, M. 1992. Species diversity and how it is affected by livestock grazing in Alberta. Range Notes prepared by the Range Management Section, Alberta Forest Service. 
Wilson, E.O. 1992. The Diversity of Life. W.W. Norton \& Co., New York, N.Y., 424 pp.

With, K.A. and T.O. Crist. 1995. Critical thresholds in species' responses to landscape structure. Ecology 76(8):2446-2459.

World Commission on Environment and Development (WCED). 1987. Our Common Future. Oxford University Press, Oxford, U.K., 400 pp.

World Wildlife Fund. 1988. Prairie Conservation Action Plan, 1989-1994. Prepared by the Wild West Steering Committee, World Wildlife Fund Canada. 38pp.

World Wildlife Fund. 1992. Canadian endangered species. Prepared by the Committee on the Status of Endangered Wildlife in Canada (COSEWIC). World Wildlife Fund, Toronto.

WWF. ca.1993. Burrowing owl at risk. Action Alert Bulletin prepared by World Wildlife Fund (WWF), Canada.

WWF. 1996. Endangered Spaces Progress Report: 95-96. No. 6. World Wildlife Fund Canada. 66pp.

Wuerthner, G. 1991 (Spring). How the West was eaten. Wilderness: 28-37.

Yahner, R.H. 1988. Changes in wildlife communities near edges. Conserv. Biol. 2:333-339. 


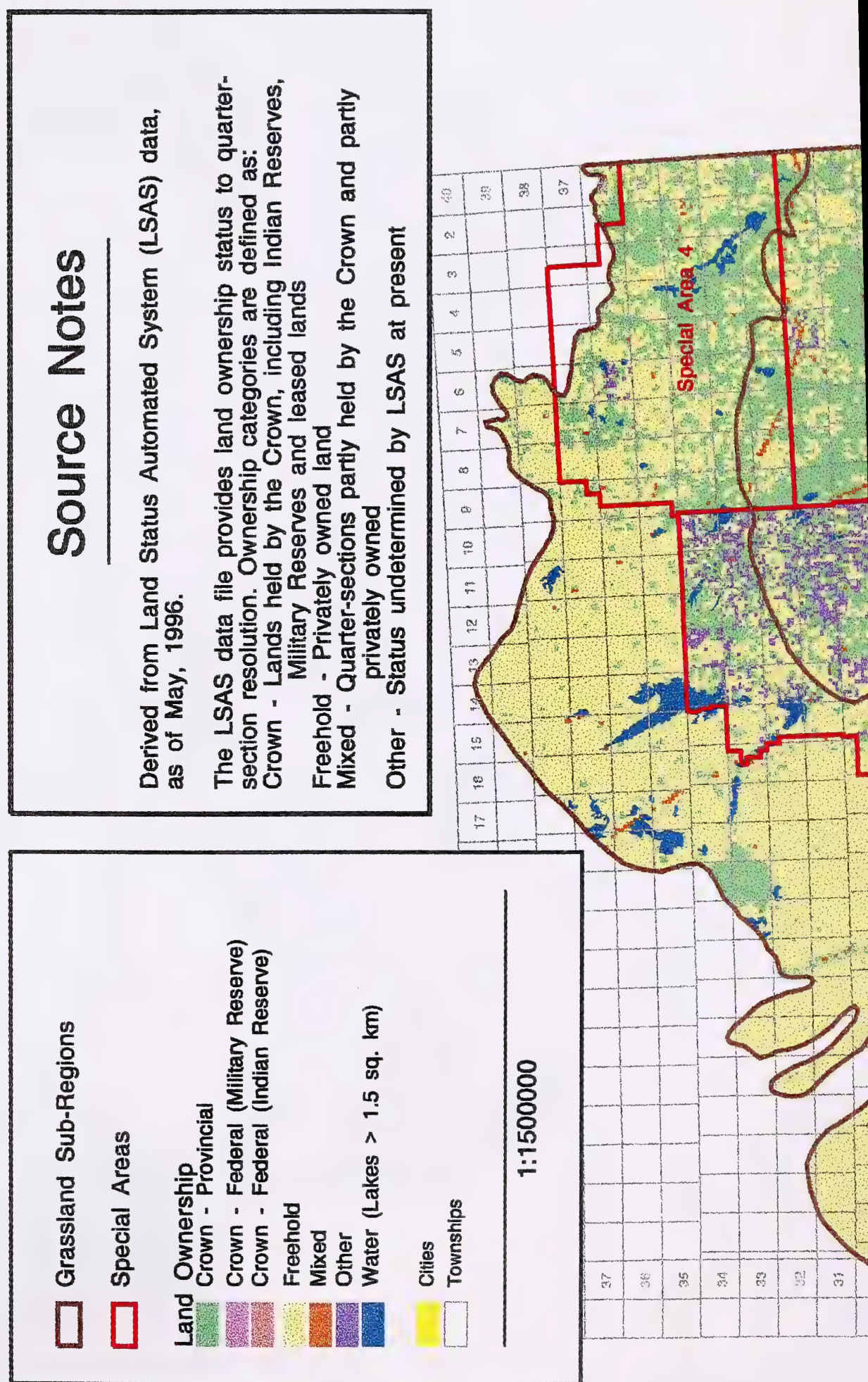




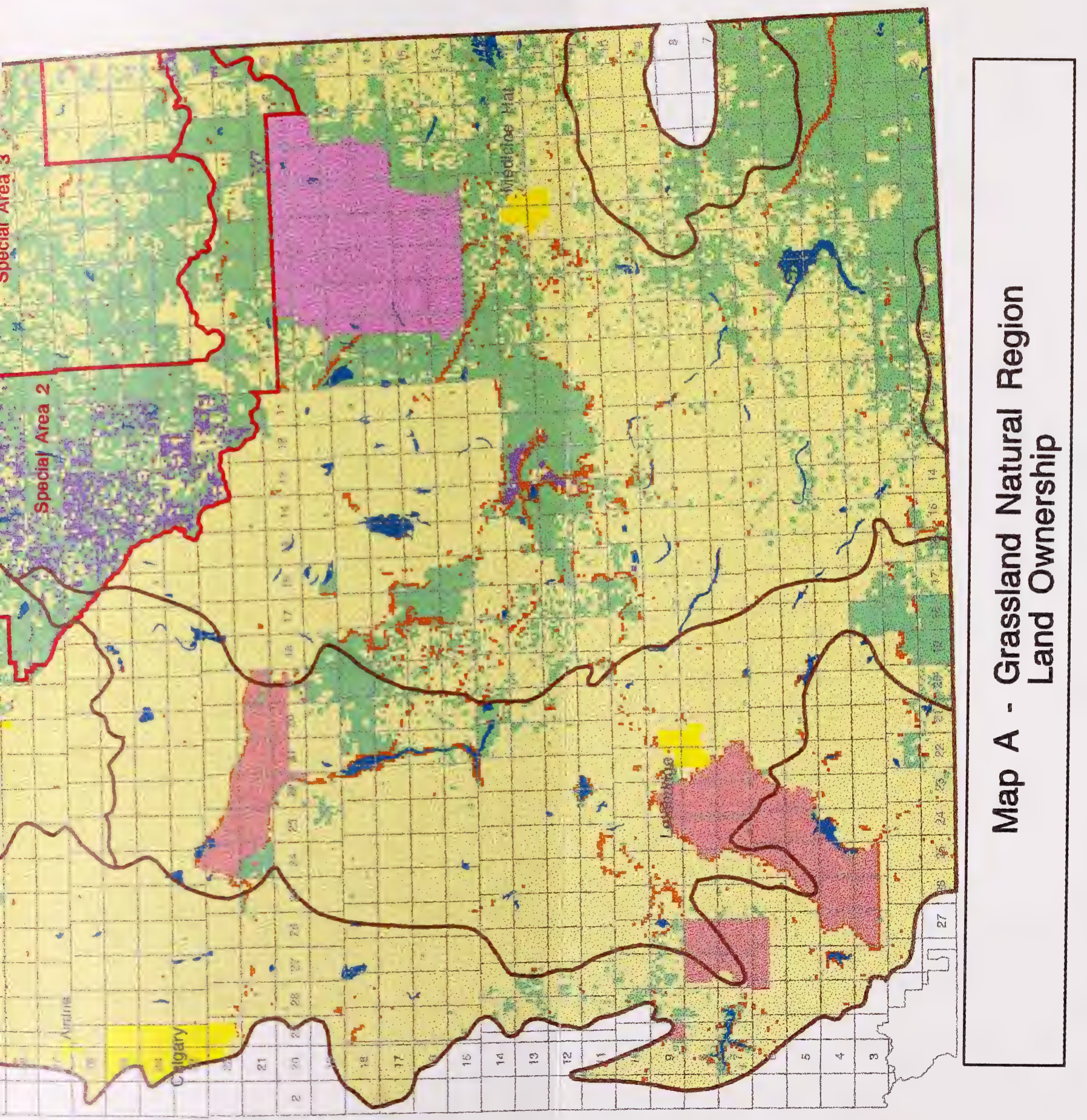



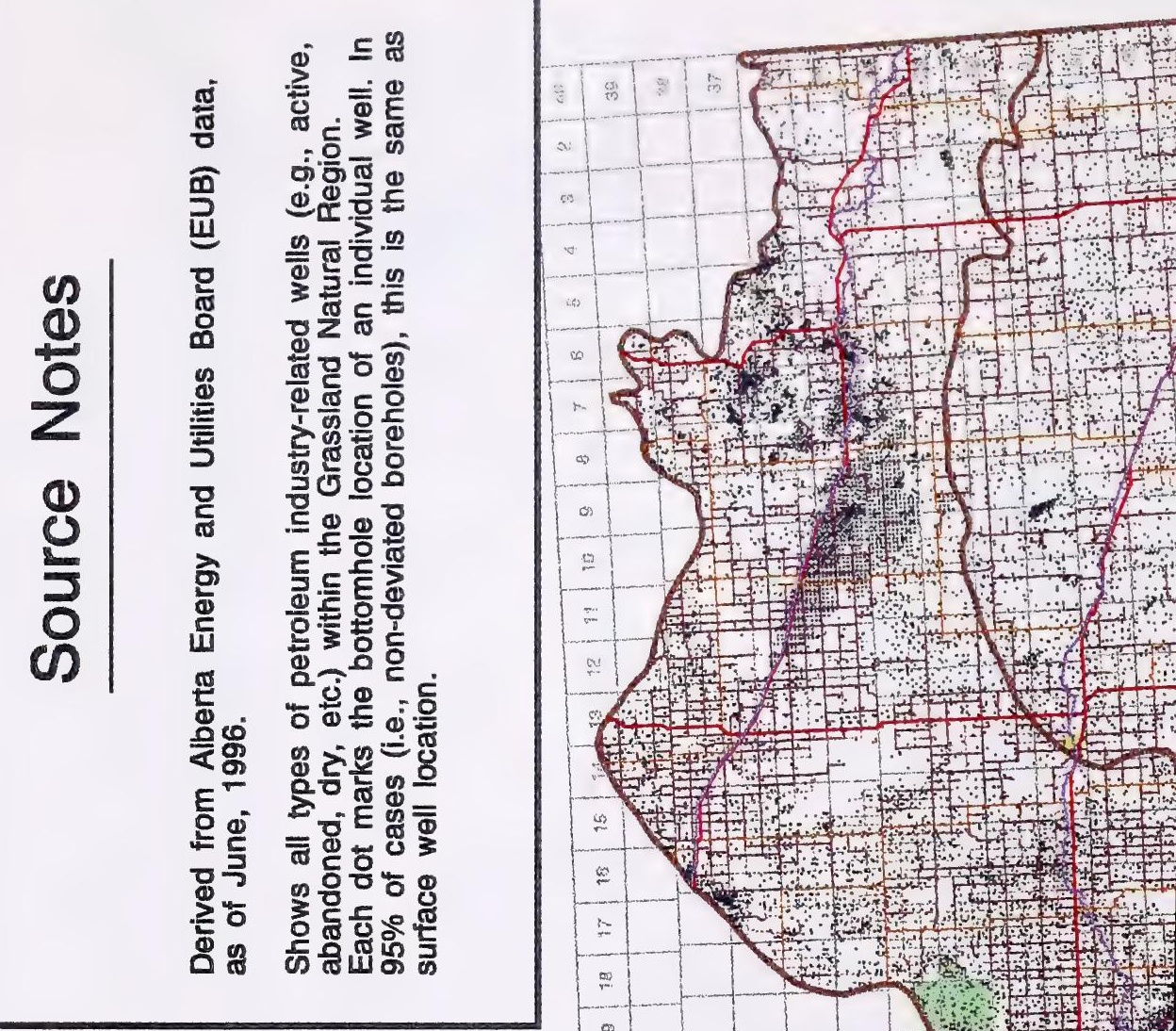

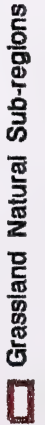
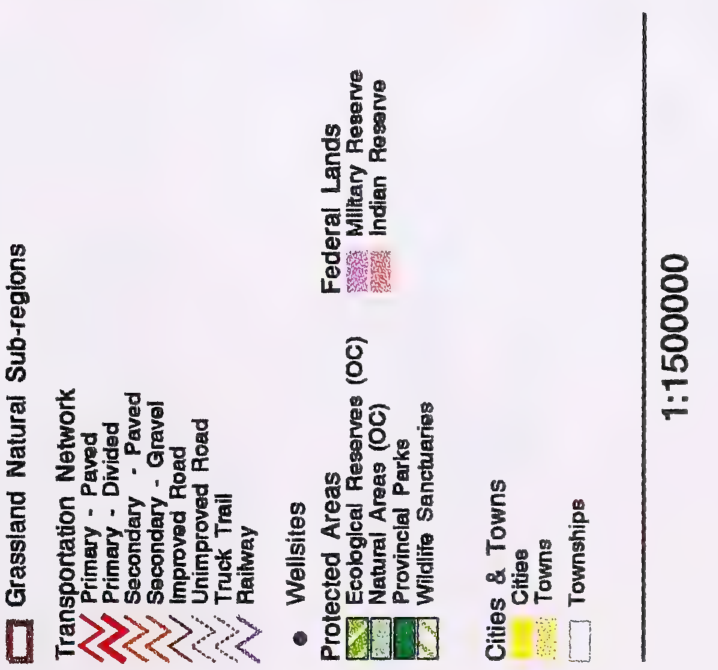


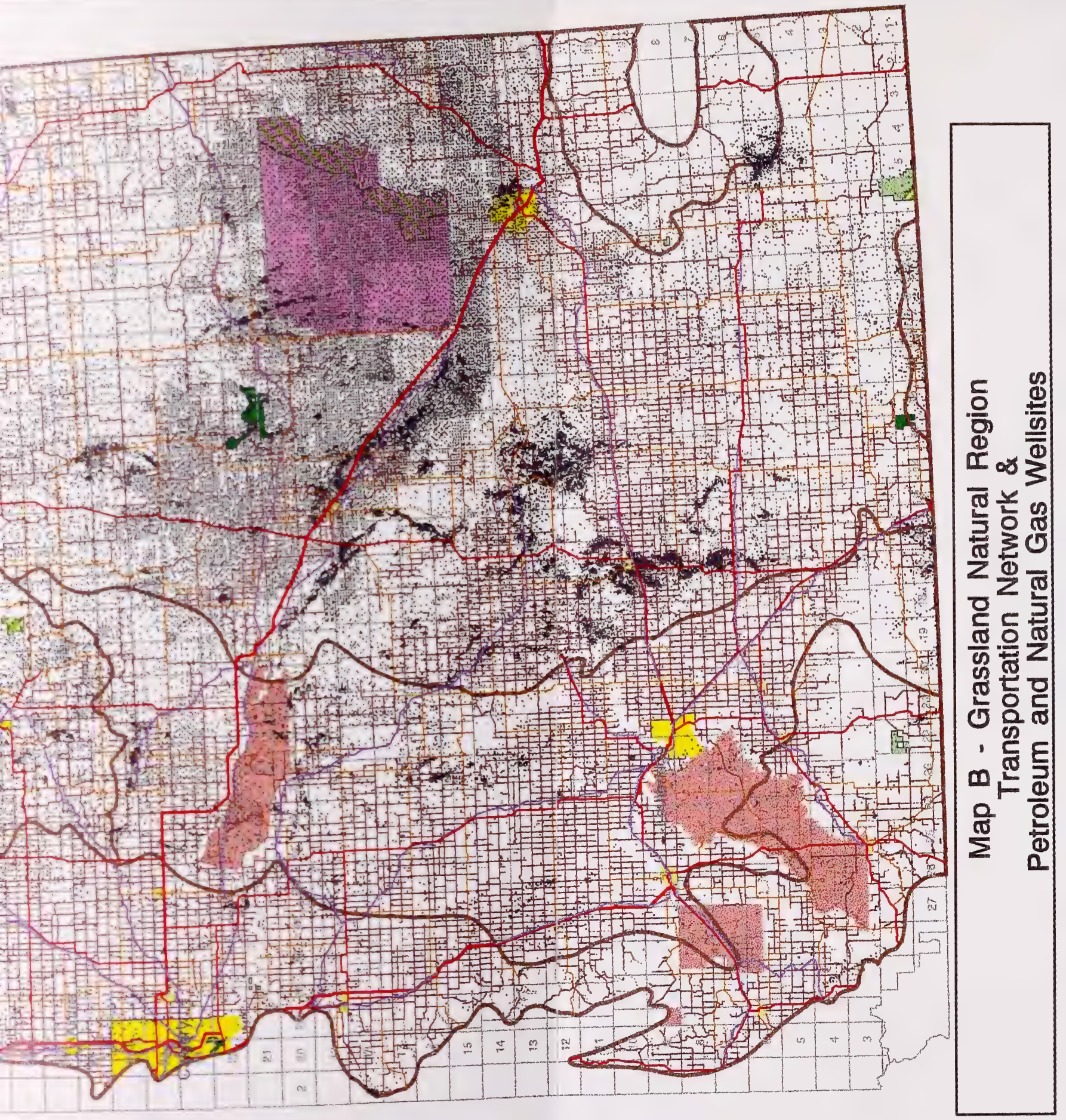




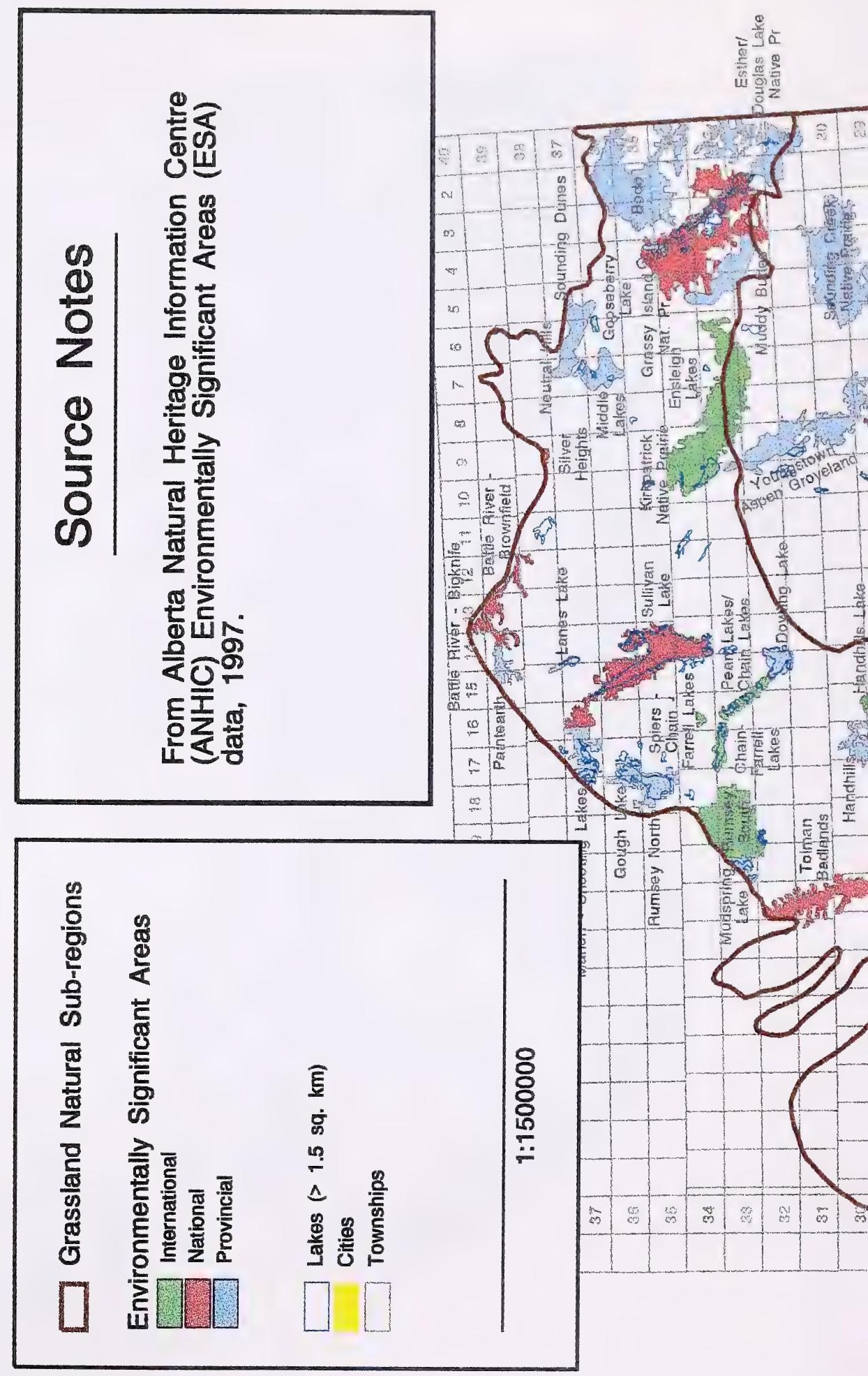




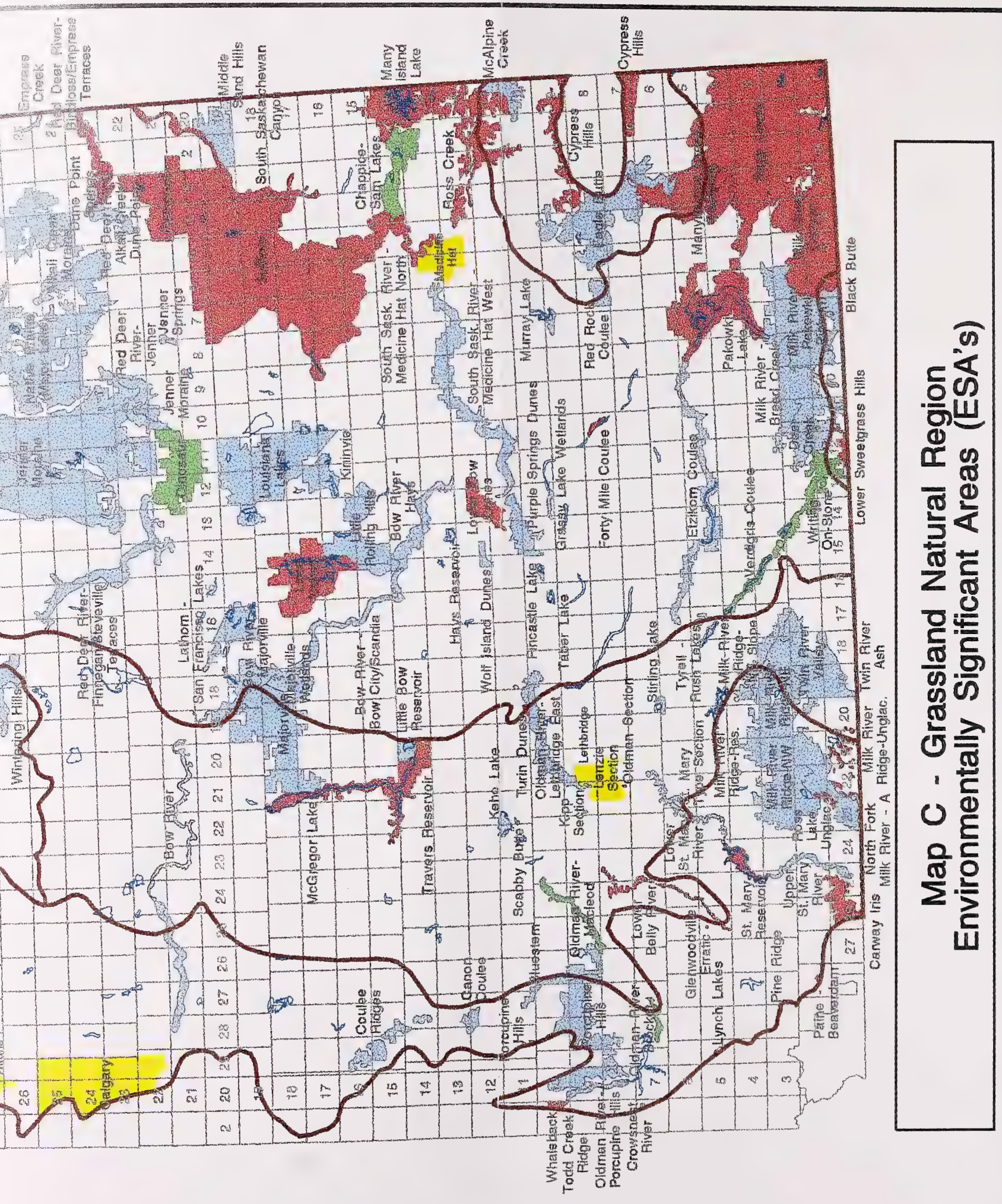



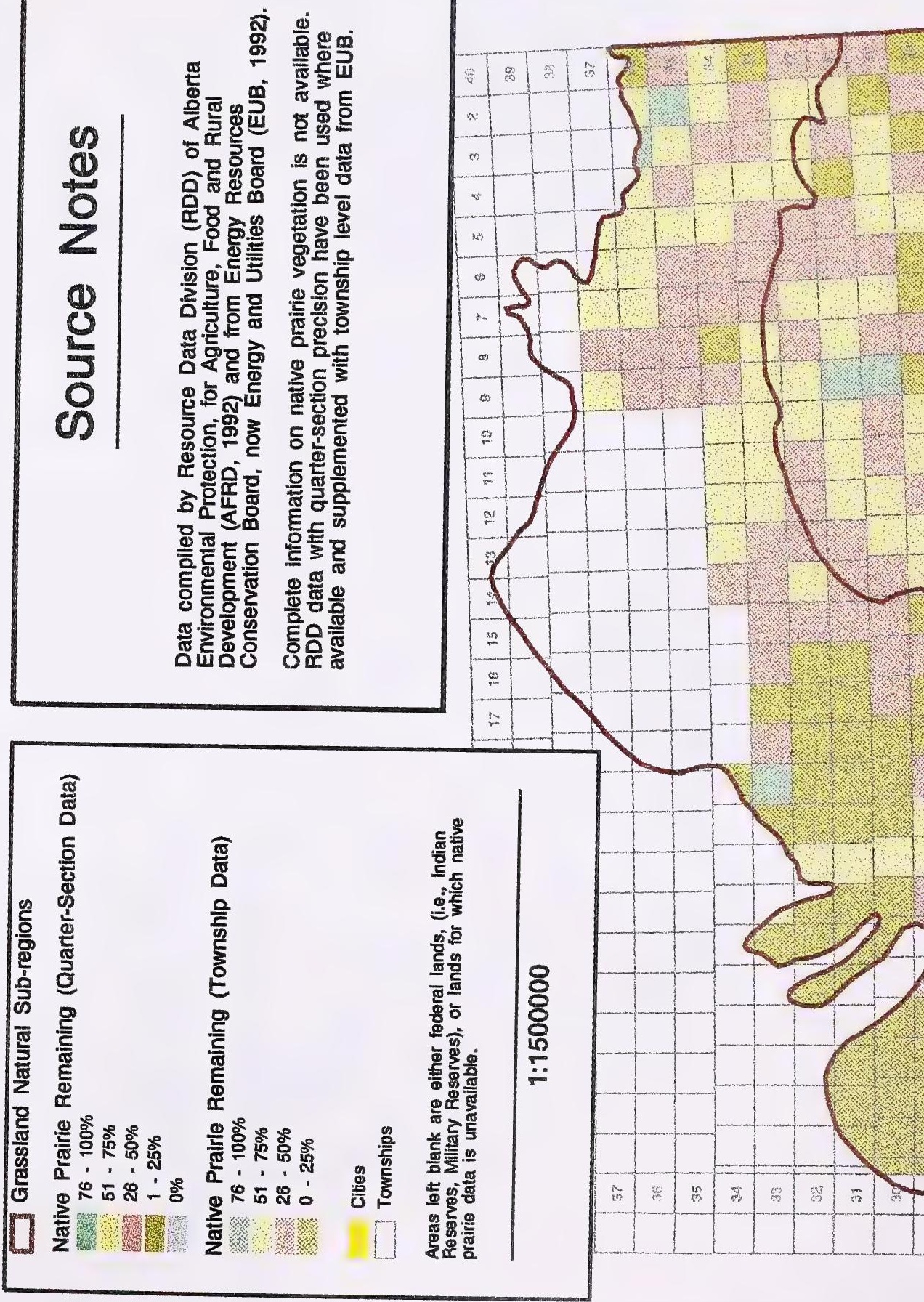

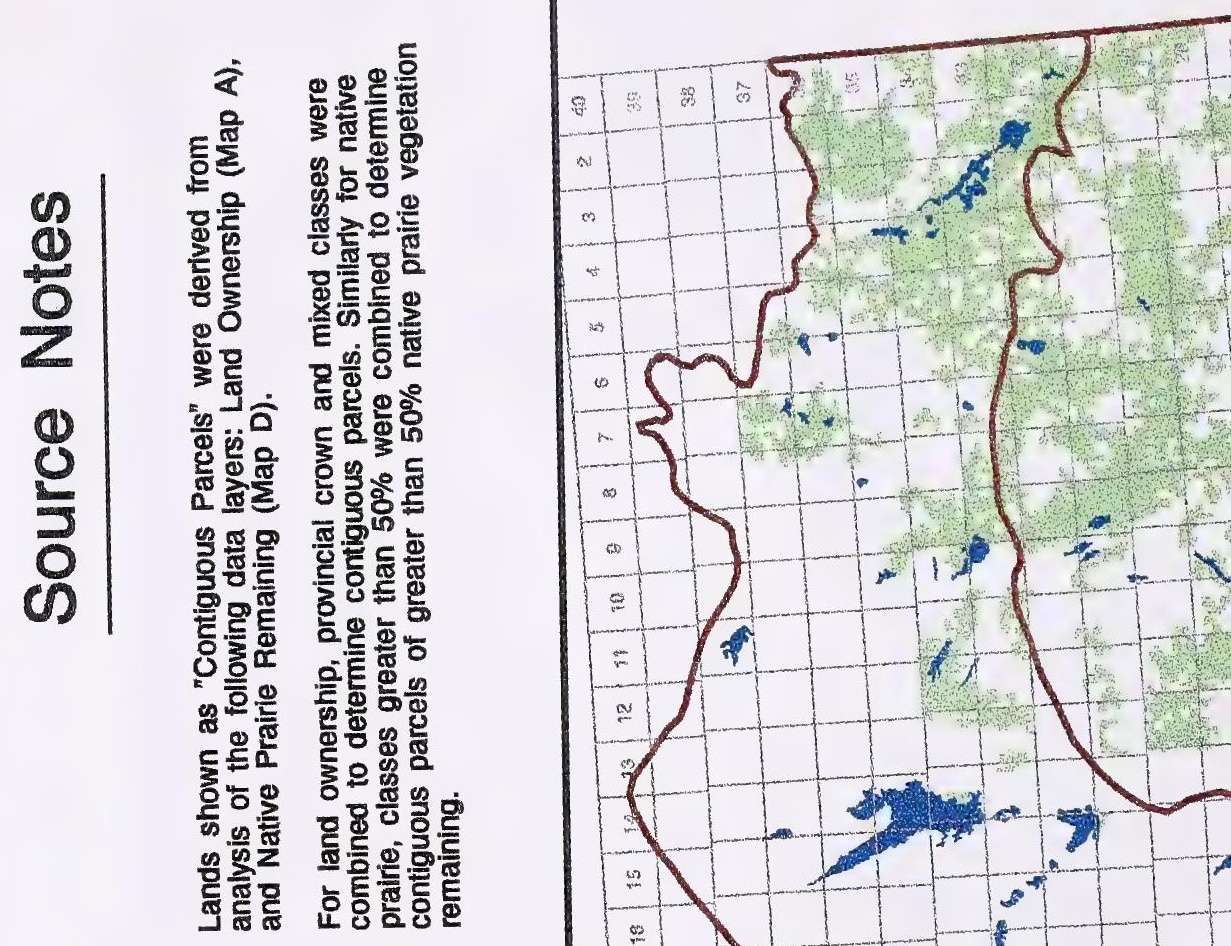


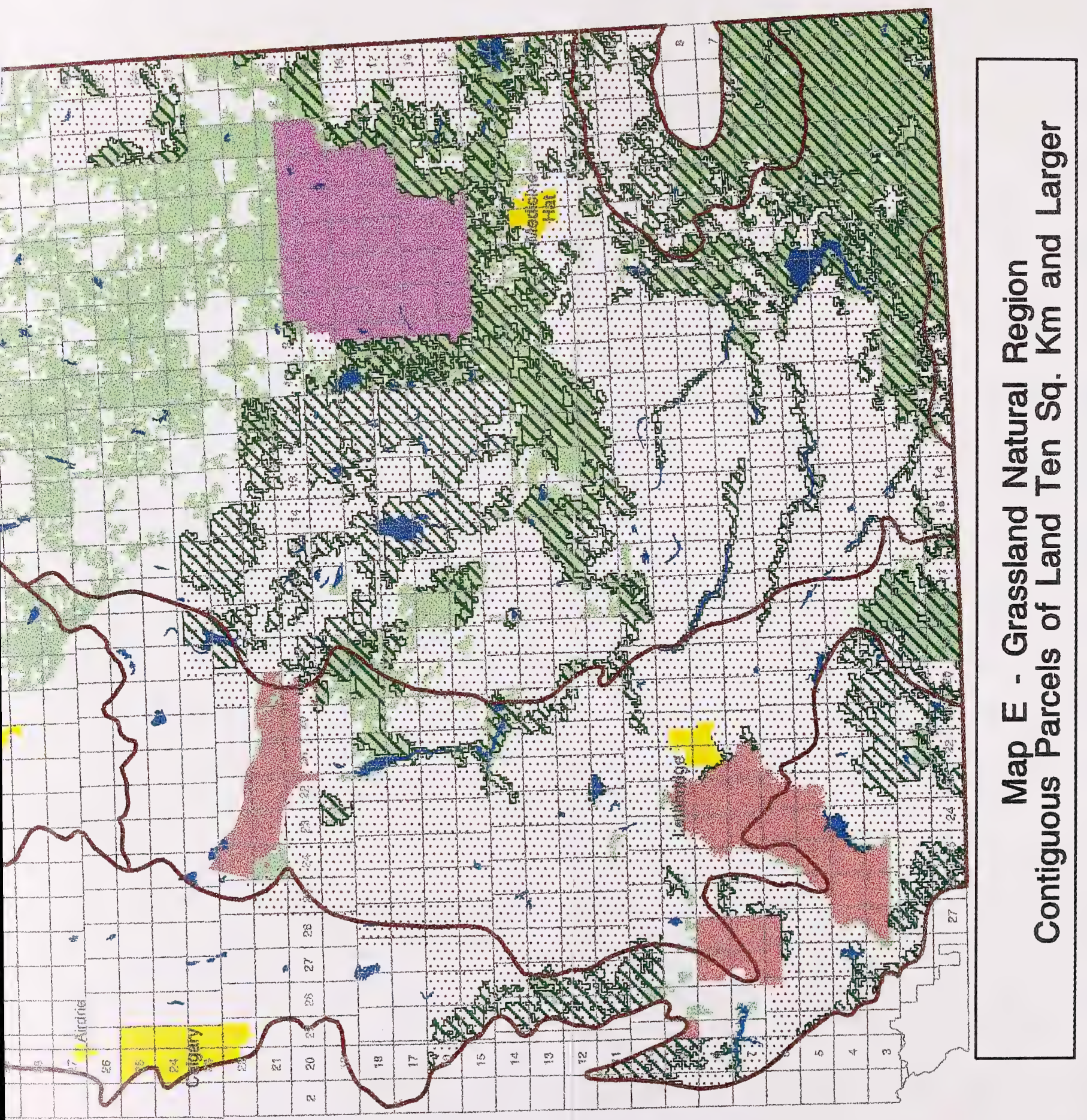




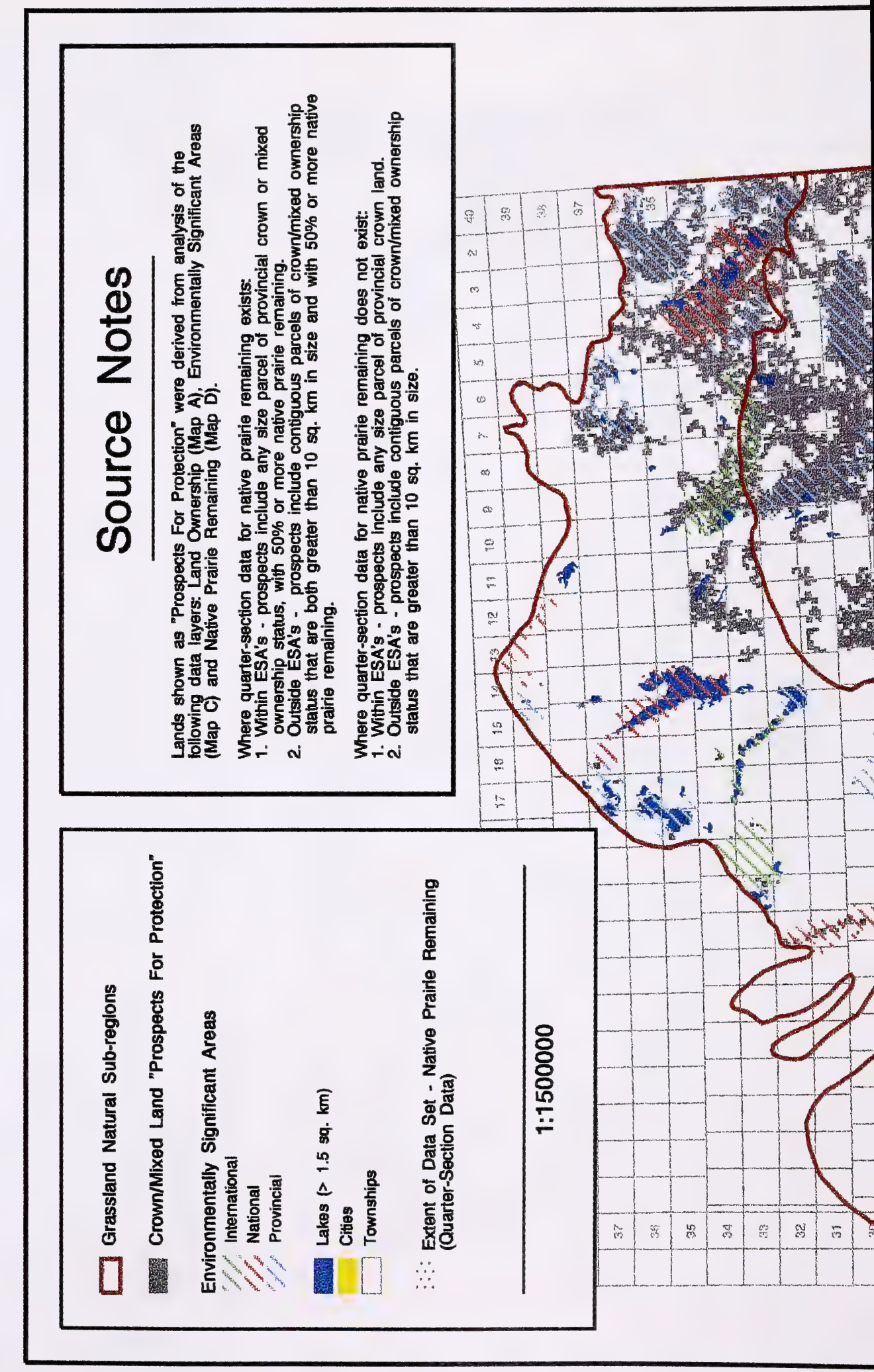




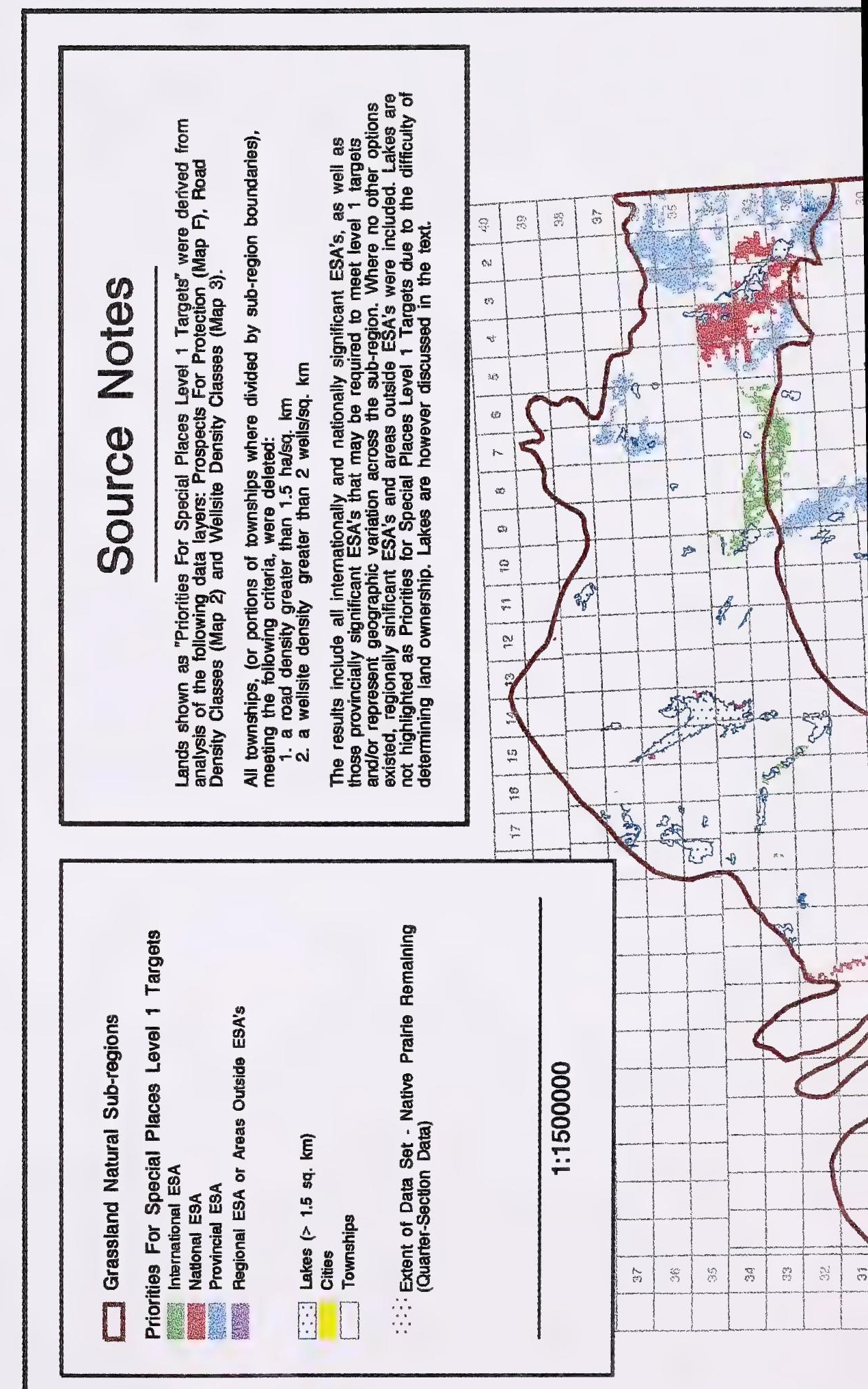




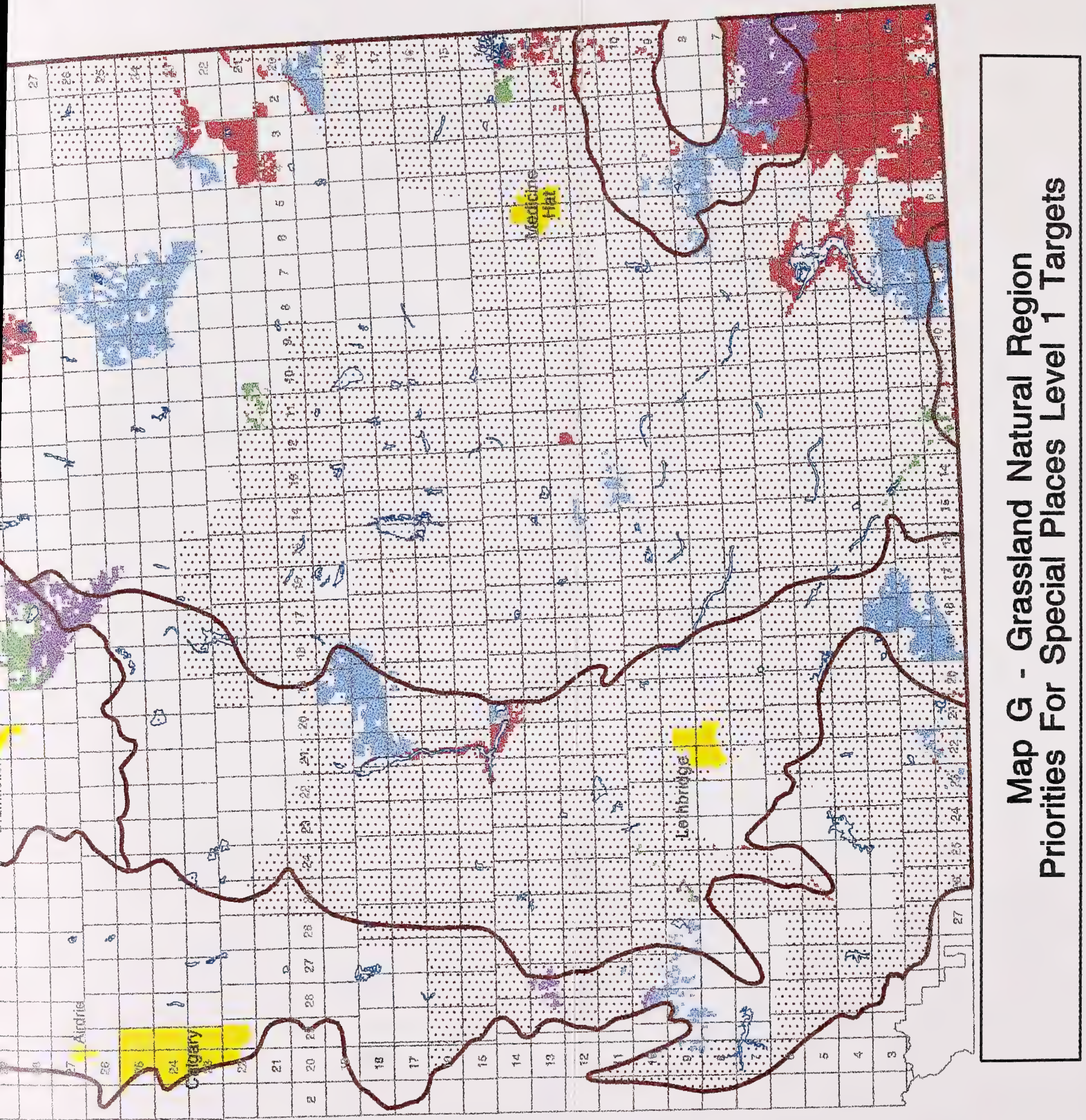





Bibliothèque nationale du Canada

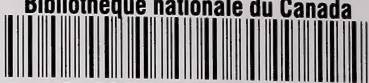

3 3286516326424 